$\frac{\text { HEAL G-C ICESOPHASE II: }}{==0}$

DETAILED FEASIBIBILITY ANYALYSIS \& PRELIMINARY DESIGH.

FOR

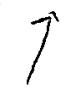

U.S. ' DEPARTMENT OF ENERGY

FINAL REPORT, STAGE 2

November, 1.978

$\sqrt{\text { CONTRACT EC-77-C-02-4337 }}$

This Norice account of work This report was prepad States Govemment. Neither the sponsored by the United Started States Department of United States nor the Uny of their employees, nor any of their Energy, nor any of their emplosers, employees, makes contractors, subcontraction, or implied, or assumes any tegal any wasranty, express or for the accuracy, completeness liability or responsibifity for the accparatus, product or or usefulness of any informastion, that its use would not process disclosed, of represents

$9500^{671^{2}}$

HEALTH EDUCATION AUTHORITY OF LOUISIANA

${ }_{950}^{53321}$. NEW ORLEANS PUBLIC SERVICE INCORPORATED

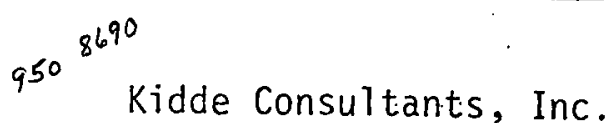

$\checkmark$$$
\text { Orr - Schelen - Mayeron and Associates, Inc. } \checkmark
$$

ill Orr - Schelen - Mayeron and Associates, Inc. $V$ 


\section{DISCLAIMER}

This report was prepared as an account of work sponsored by an agency of the United States Government. Neither the United States Government nor any agency Thereof, nor any of their employees, makes any warranty, express or implied, or assumes any legal liability or responsibility for the accuracy, completeness, or usefulness of any information, apparatus, product, or process disclosed, or represents that its use would not infringe privately owned rights. Reference herein to any specific commercial product, process, or service by trade name, trademark, manufacturer, or otherwise does not necessarily constitute or imply its endorsement, recommendation, or favoring by the United States Government or any agency thereof. The views and opinions of authors expressed herein do not necessarily state or reflect those of the United States Government or any agency thereof. 


\section{DISCLAIMER}

Portions of this document may be illegible in electronic image products. Images are produced from the best available original document. 


\section{TABLE OF CONTENTS}

Introduction - Summary

$\underline{\text { TASK I b }}$

SECTION

PAGE

Revised Work Plan, Phase III

Revised Work Plans, Phases IV, V, VI

1b. 1

$1 b .2$

4

13.

TASK II b

HEAL-NOPSI Lease-Operating Agreement

$2 b .7$

36

NOPSI Updated Rate Schedule

$2 b .2$

63

NOPSI Long-Term Energy Supply

$2 b .3$

70

Contracts With Institutions Financing Plan,

Bond Issue

2b. 4

84

Plant Site Option Agreement

$2 \mathrm{~b} .5$

89

Easement and Right-of-Way Agreements

$2 \mathrm{~b} .6$

93

Zoning Variance

$2 \mathrm{~b} .7$

96

Labor Relations Plan

Preliminary Environmental Assessment

$2 \mathrm{~b} .8$

97

$2 b .9$

98

$\underline{\text { TASK III b }}$

(NONE)

TASK IV b

Design Description of ICES PIant

$4 b .1$

$4 b .2$

Preliminary Process, Piping \& Instrument Schematics

$4 \mathrm{~b} .2$

164

Equipment \& Instrumentation Schedule; Outline

Specifications for Major Components

Preliminary Design: Electrical \& Instrumentation

Systems

$4 b .3$

Preliminary Design: Site Plan, Elevations, Equipment Layout, Distribution Systems

$4 \mathrm{~b} .4$

Engineering Analyses - Detailed Design \& Construction

$4 b .5$

224

$4 b .6$

246 


\section{TASK $\vee \mathrm{b}$}

Final Preliminary Design Cost Estimate

$5 b .1$

$5 b .2$

265

Final Owning \& Operating Cost Estimate

$5 b .3$

268

Final Financial Analys is

DOE - Funding Proposal

$5 b .4$

272

276

APPENDIX

Letter to IRS re Bonds' Tax - Exempt Status

A 1

277

Sources of Cost Data

B 1

288

HEAL Institutions' Letters of Interest

C 1

299 


\section{INTRODUCTION AND SUMMARY}

This is the second and last part, Stage 2, of the work required for Phase II, Detailed Feasibility and Preliminary Design, of the HEAL G-C ICES program.

Work plans for Phase III and also for Phases IV, V, and VI were revised. There was very little change from these work plans as presented in the Phase I report; the work scopes remained essentially the same; there were nominal reductions in manpower schedules and corresponding cost reductions. A schedule of procurement for long-lead items was included with the Phase III work plan.

Institutional issues were advanced and are presented in Task IIb. Drafts of the HEAL-NOPSI lease-operating agreement and of the long-term energy supply contracts between NOPSI and the HEAL institutions (users) have been included, as well as for the plant site option agreement and for the easement and right-ofway agreement. NOPSI's updated rate schedule, based on data developed during the Phase II study, is one of the Task IIb documents, as are statements relative to possible zoning variances and a labor relations plan for ICES plant system operation. A preliminary environmental assessment is presented in Section 2b.9.

The intent throughout this Phase II feasibility study has been to determine economic and environmental feasibility of a Grid-Connected Integrated Community Energy System based on a multifuel design with which to serve any or al7 the institutions within the Louisiana Medical Complex in cooperation with the Health Education Authority of Louisiana.

In this context, a preliminary design is presented in Task IVb and consists of ICES plant description and engineering analyses. This demonstration system is capable of meeting 1982 system demands by providing 10,000 tons of air conditioning and, from a boiler plant with a high-pressure steam capacity of 200,000 pounds per hour, approximately 125,000 pounds per hour of 185 psig steam to the HEAL institutions, and at the same time generating up to $7600 \mathrm{KW}$ of electrical power as byproduct energy. The plant will consist of multiple-fuel steam boilers, turbine generator, turbine driven chillers and necessary auxiliaries and ancillary systems. The preliminary design for these systems and for the building to house the central plant systems appears on drawings which are included in the sections under Task IVb, along with equipment and instrumentation schedules and outline specifications for major components.

Costs were updated to reflect data as revised and refined during the Phase II work effort. The final preliminary cost estimate appears in Section 5b.1 and includes allowances for contingencies and escalation, as well as cost for the plant site and professional fees. The estimated total cost is $\$ 34,750,000$. Sources of cost data used in developing the estimate are documented in Appendix B1.

This design is for a facility specifically with coal burning capability- recognizing that it is more capital-intensive than a gas/oil facility. In the opinion of the Louisiana Department of Natural Resources (DNR), the relatively modest allocations made here for scrubbing and ash removal involve less than is implied in standard industry (EPRI) cost increments of over $30 \%$ for these duties. 
Prototype estimates for owning and operating costs were calculated using 1982 base prices of $\$ 2.25 / \overline{M B}$ TU for a premium grade coal and gas at $\$ 3.23 / \bar{M} B T U$. Uniform annual escalations through the year 2000 were taken at $5 \%$ for coal and $8 \%$ for gas, yielding year 2000 prices for the two fuels of $\$ 140.62 /$ ton (vs. $1982 \$ 58.43 /$ ton) for coal and $\$ 13.35 /$ MCF (vs. $1982 \$ 3.39 / M C F$ ) for gas. These numbers have been drawn partly from nonbinding replies to inquiries of specific coal suppliers.... and from published U.S. Department of Energy projections. DNR does not agree with these numbers and accordingly has taken exception to the 1982 operating cost estimates computed here of $\$ 8,154,545$ for coal and $\$ 9,233,975$ for gas. DNR also disputes the down-stream projections to 2000. Their specific concerns include these: (a) After a four-fold increase in gas prices as projected, the Department feels that there will result both alternate supplies (domestically and perhaps from Mexico) and decreased demand which will make the monotonic $8 \%$ annual price increase from \$3.39/MCF inappropriate. The coal price rise (including delivery), at the more modest $5 \%$ level is likewise viewed as not fully supported. There is further concern about the failure to distinguish between the part of the price increase attributable to simple inflation and that due to increased scarcity or demand development; (b) Continuing to price byproduct electricity at a $50 \%$ fraction of purchased electricity cost after a nearly four-fold projected increase of cost (7\%/year) is questioned. The $4.5 \$ / \mathrm{KWH}$ cost has already absorbed one quantum jump; further the discount on in-plant generation is not necessarily a constant fraction of steeply rising total costs; (c) It was felt by DNR that ash removal and slurry disposal were underestimated in the presentation in this report.

The appropriateness for further review in response to the aforementioned concerns before endorsement by the State of further capital commitment to this enterprise is acknowledged. Nevertheless, a conditional "final analysis" of the financial aspects of the HEAL G-C ICES program has been prepared in Section $5 \mathrm{~b} .3$ which is presented here subject to future review in the context of the preceding objections. This analysis includes data for the anticipated first year of plant operation--1982--and projects a similar analys is for operations through the year 2000. For 1982, the required gross revenue for a coal-fuel plant is estimated at $\$ 9,829,075$, with a required net revenue of $\$ 8,154,545$; gross revenue for 1982 has been estimated at $\$ 9,808,330$. A gas-fuel plant would have an estimated $\$ 10,908,505$ required gross revenue, $\$ 9,233,975$ required net revenue, $\$ 10,909,859$ estimated gross revenue.

Based on the criteria that appeared in ERDA (now DOE) RFP No. E (11-1) P-76-0016 a preliminary schedule of proposed funding by DOE for Phase III appears in Section 5b.4, with an estimated total of $\$ 87,186$. Similar estimates for Phases IV, $V$ and VI also are listed, with the estimated totals $\$ 161,200$ for Phase IV, $\$ 184,156$ for Phase $V$, and $\$ 64,512$ per year for Phase VI.

In summary, the study had evaluated the design and economics of a multifuel plant (i.e. one in which gas, oil, treated solid waste as available and coal may all be used). This means that the alternative of a gas/oil facility without coal firing capability was explicitly not addressed. Clearly coal firing could be mandated by statute and the multiple fuel flexibility suggested here would be an only and limited alternative. State government has expressed considerable concern about the prospects of abandoning what priorities for gas/oil use the hospital complex may have as a human-need consumer in the innocent pursuit of an inadequately explored coal-burning option-- in the opinion of DNR. 
In particular, both executive and legislative branches of state government have made it clear that any decision to commit to a plant with coal-burning capability must be accompanied by some measure of assurance that this investment in flexibility will not lead to mandated use of coal simply because the capability to use it had been created. Coal use would be sanctioned if given the following circumstances:

1. That significant cost savings with coal as the primary fuel could be demonstrated to the satisfaction of the Louisiana State Department of Natural Resources, the Joint Legislative Committee on Natural Resources, and the user institutions; and

2. That all environmental impact reports had been reviewed and approved by responsible state, local and federal agencies.

This Phase II report presents the stand-alone technical feasibility demonstration of a multifuel facility. It does not seek to demonstrate this as the most economically attractive alternative, from the perspective of the State, for the HEAL complex, but that was not its purpose. Attention is directed to the Phase I report for a more comprehensive analysis of alternatives.

\section{Footnote:}

Comments, opinions, questions and observations in this Introduction and Summary which are of apparent exception or contradiction to the detailed material in this report are contributions of the Louisiana joint Legislative Committee on Natural Resources and have been inserted at their request. 
TASK I B

REVISED WORK PLANS, STAGE II 


\section{1.b.1 PHASE III}

\section{1.b.1.1 Revised Work Plan}

a) Work Package

Work will be accomplished as defined in the following scope, which has been divided into two sections -- final design, and operation and maintenance procedures. The parenthetical number applied to each deliverable item indicates the work task number in the manpower schedule.

1) Phase III(a) - Final Design

Complete the final design and construction working drawings and prepare a Final Design Documentation Package which will include design analyses, engineering calculations, detailed design drawings, detailed construction drawings, installation drawings of the subsystems and components, updated equipment layout drawings, updated procurement, delivery and installation schedules, appropriate equipment test program, mockups, updated program plans, procedures, schedules and a final cost estimate of the Demonstration System.

a. Deliverables:

Final Design Report, including:

- Detail construction working drawings (12)

- Construction specifications (13)

- Installation drawings (14)

- Design analyses and reports, including engineering calculations (15)

- Procurement specifications (16)

- Mockups and models (17)

- Updated program procedures and schedules (18)

- Construction cost budget - final cost estimate (19)

- Distribution system layouts and network drawings (20)

2) Phase III(b) - Operation and Maintenance Procedures

Define and prepare operating and maintenance procedures required for the system and submit for DOE approval a detailed operation and maintenance procedures manual a minimum of 90 calendar days prior to the major milestone signaling the start of the Plant Start-Up Test.

a. Deliverables:

- Operation and maintenance procedures (21)

- Operation and maintenance manual (22)

- Final Environmental Statement (23)

b. Project Charts:

1. Project Management Team

Chart 1 shows the project management team. 


\section{Consortium Organization}

Chart 2 shows the consortium organization.

3. Chart 3 shows, in PERT format, the projected work flow.

c. Phase III Program Costs

Man-Month Costs:

Work Task \#

$$
\begin{array}{rr}
12- & \$ 404,333 \\
13- & 95,594 \\
14- & 55,960 \\
15- & 62,415 \\
16- & 72,787 \\
17- & 22,304 \\
18- & 46,855 \\
19- & 63,913 \\
20- & 143,555 \\
21- & 20,607 \\
22- & 32,279 \\
23- & 16,933 \\
\hline
\end{array}
$$

Sub-Total

Environmental Consultant

General Legal

Bond Counsel

Public Meeting \& Communications

(Public Relations)

Topographic and Right-of-Way Surveys

Soils Investigation

Reproduction and Printing

Travel

Per Diem

$$
\begin{array}{r}
\$ 1,037,535 \\
4,000 \\
50,000 \\
56,500 \\
25,000 \\
25,000 \\
5,000 \\
23,000 \\
11,800 \\
13,800 \\
\hline \$ 1,251,635
\end{array}
$$

Total Estimated Cost 


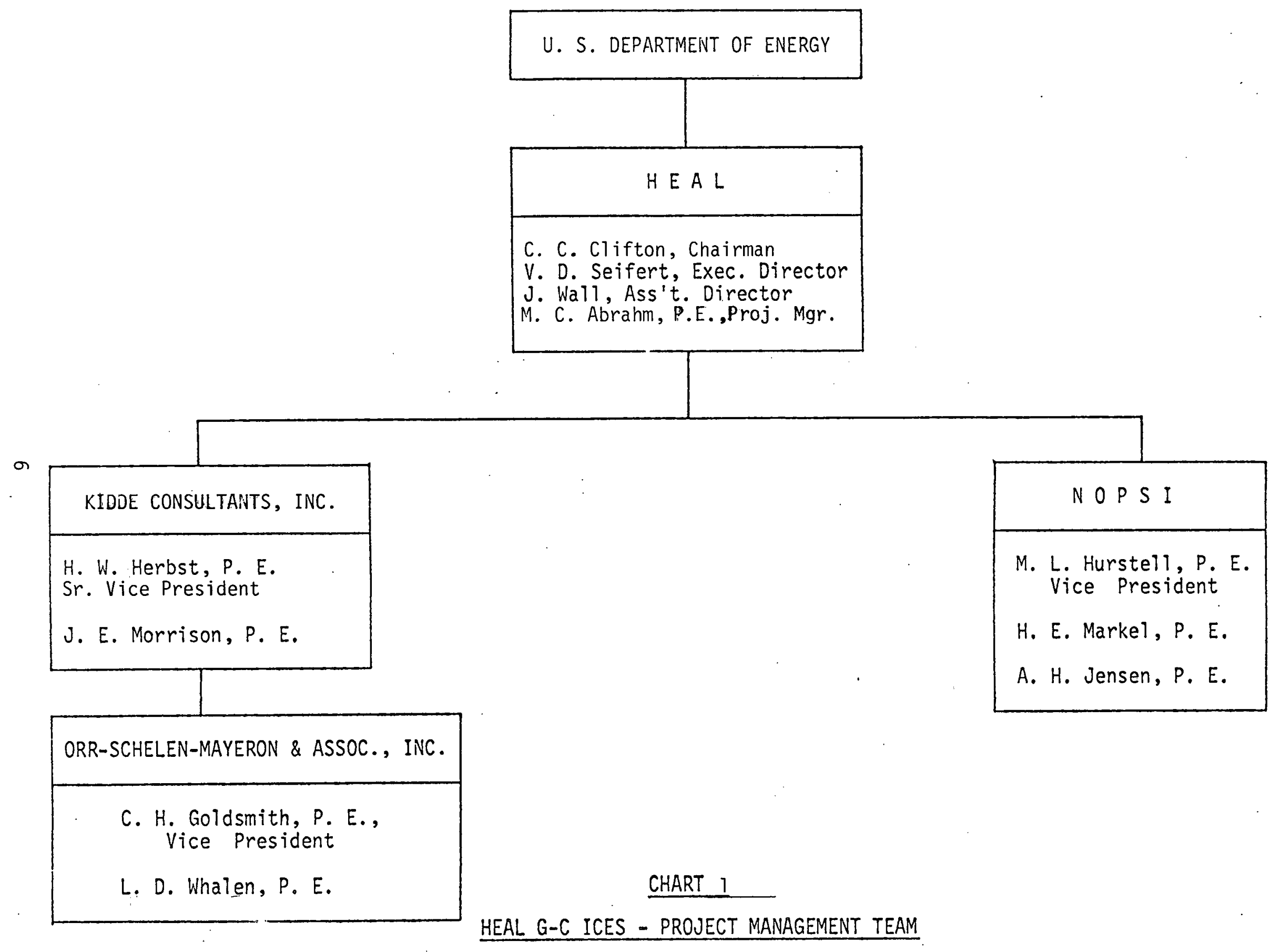




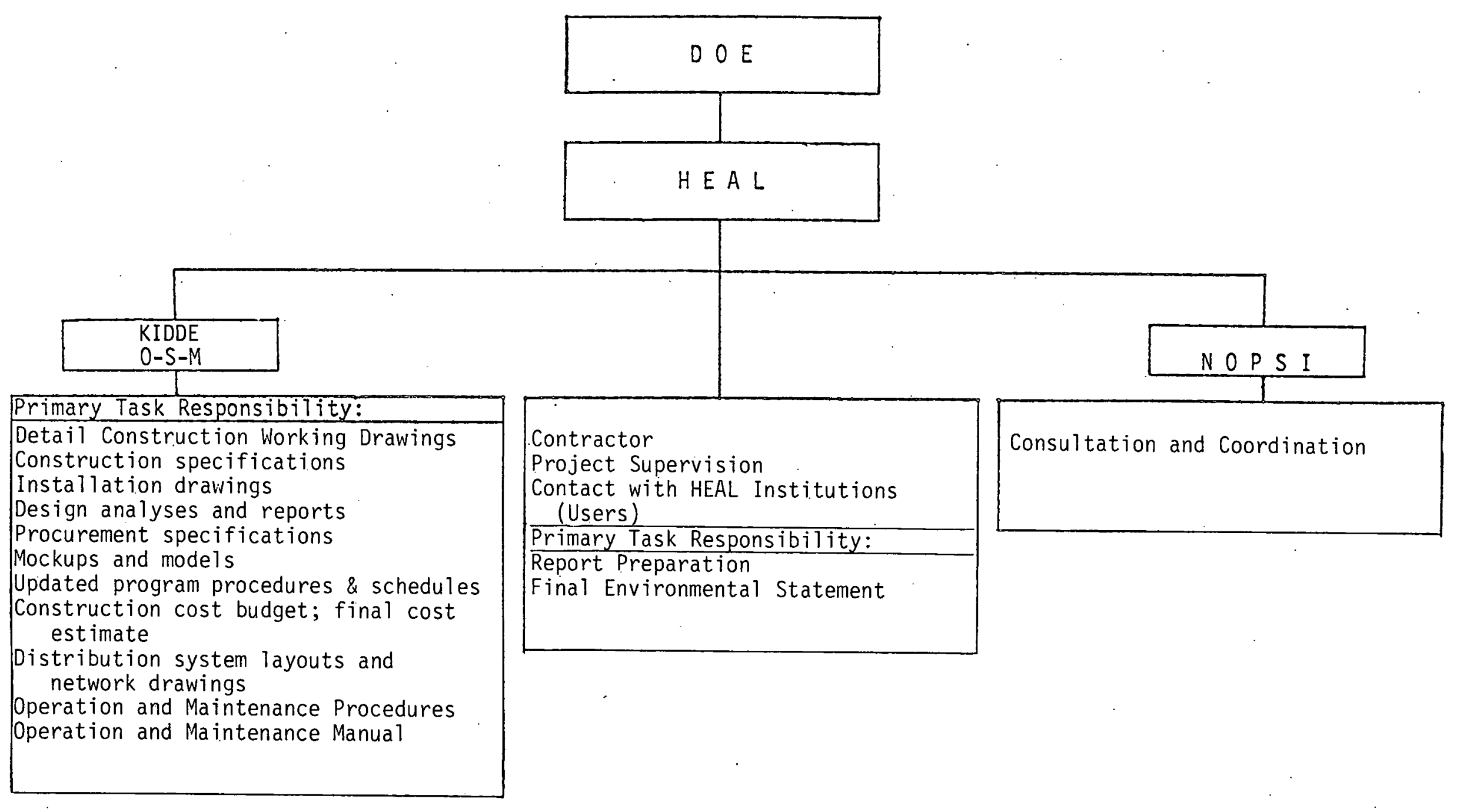

CHART 2

HEAL G-C ICES - CONSORTIUM ORGANIZATION 


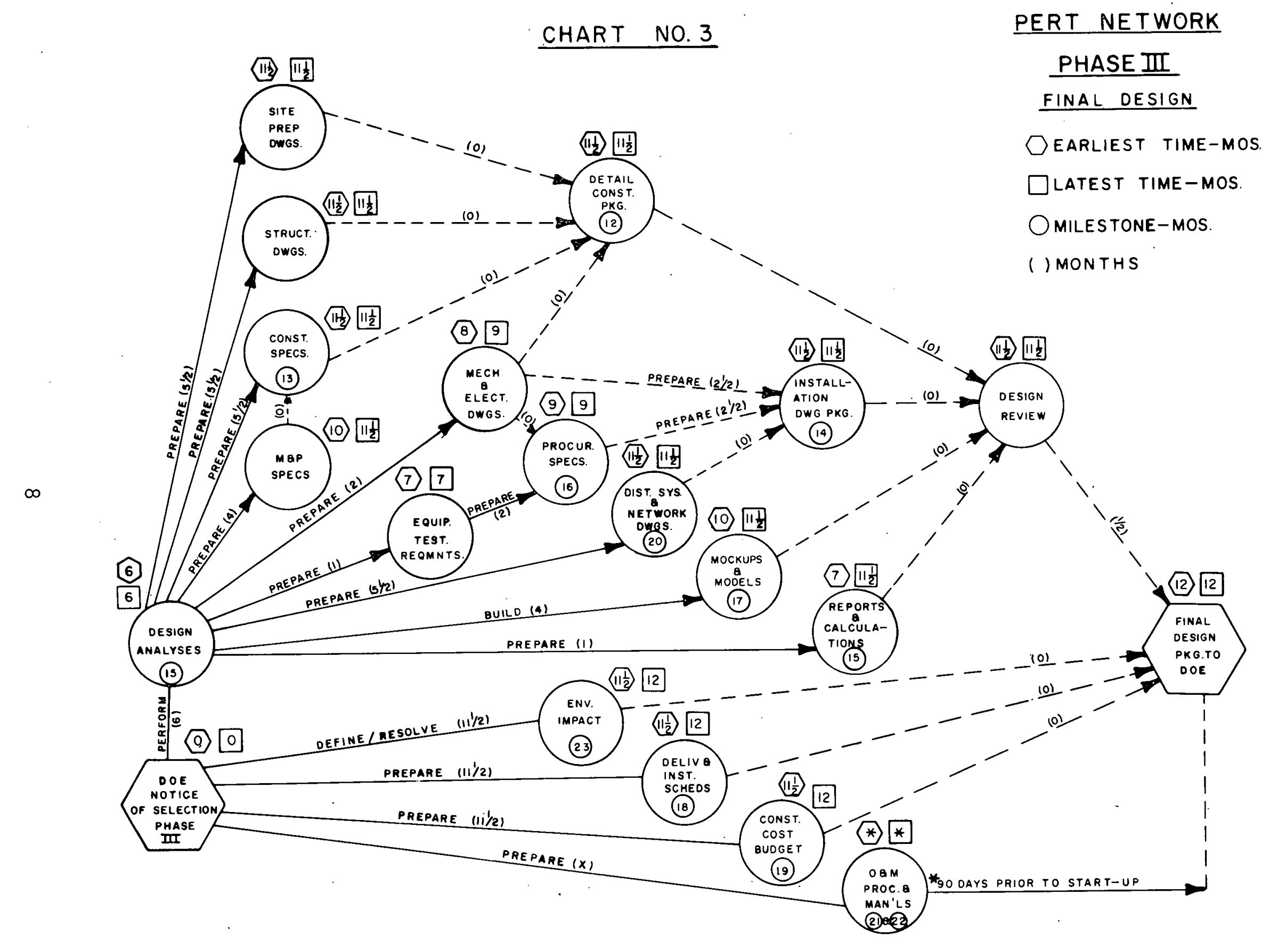




\section{d. Manpower Schedule}

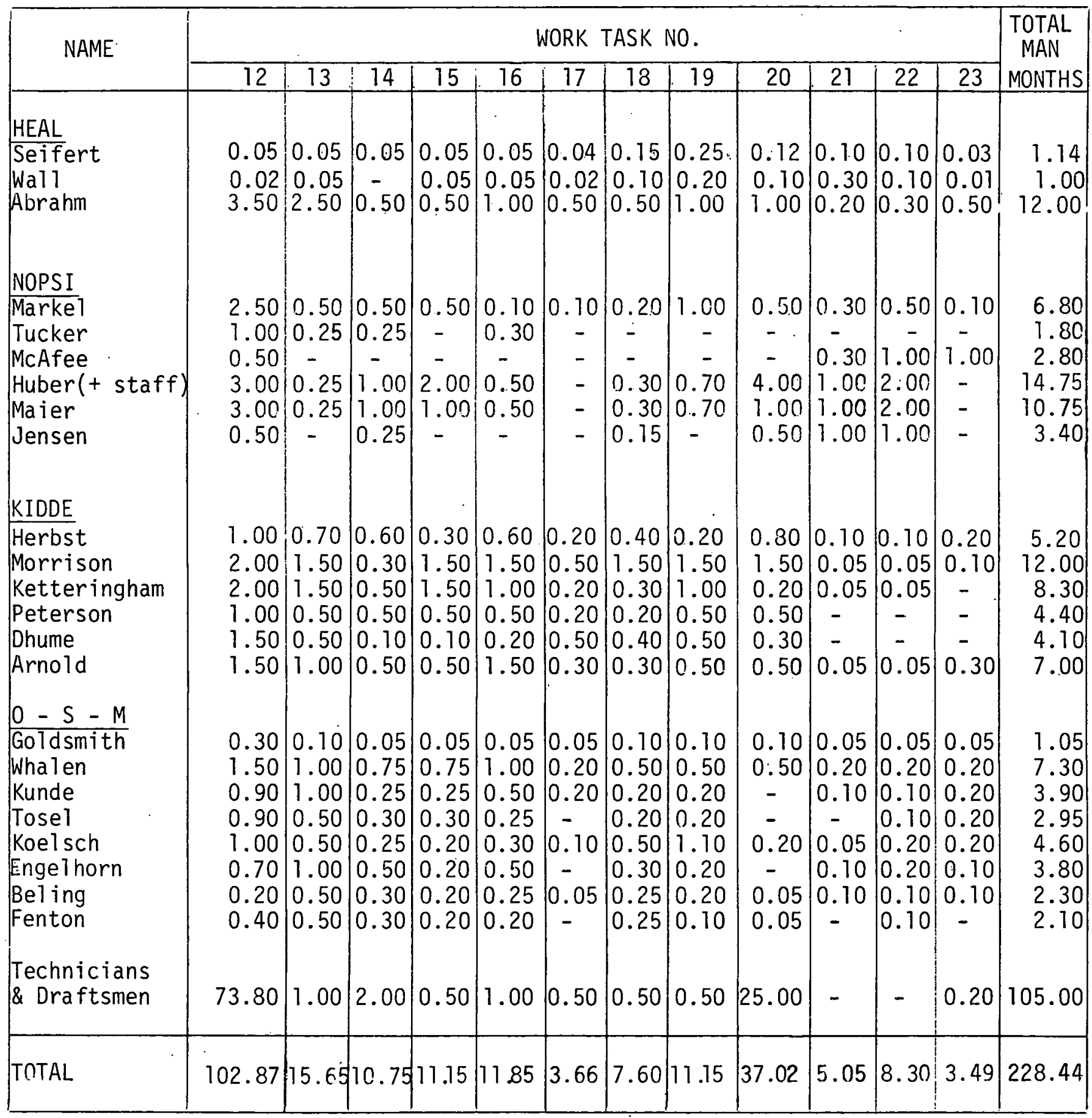




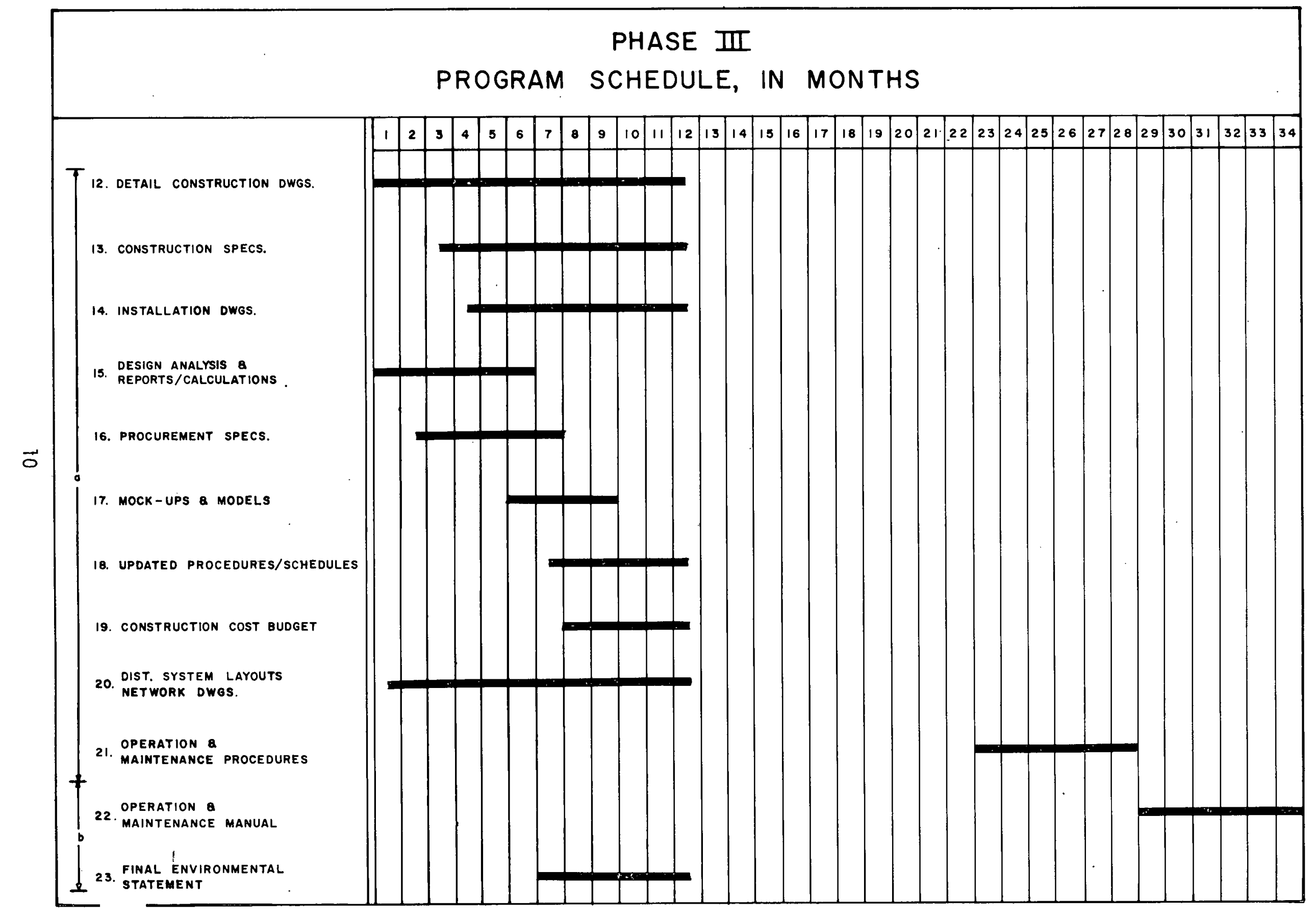


1.b.1.2 Schedule of Procurement For Long Lead Items

Procurement ScheduTe -- Long Lead Items on the following page lists major long lead items and their tentative schedule for procurement, based on an estimated construction period of 30 months. 


\section{PROCUREMENT SCHEDULE - LONG LEAD ITEMS}

\section{CONSTRUCTION PERIOD - 30 MONTHS}

PROCUREMENT TIME

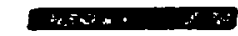

MONTHS

ITEM

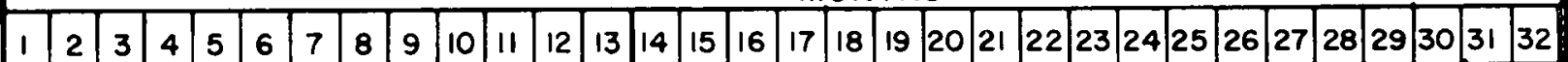

BOILERS \& APPURTENANCES

BOILER FEED PUMPS

8 DRIVES

SCRUBBERS \& I.D. FANS

\& FAN DRIVES

$\vec{N}$

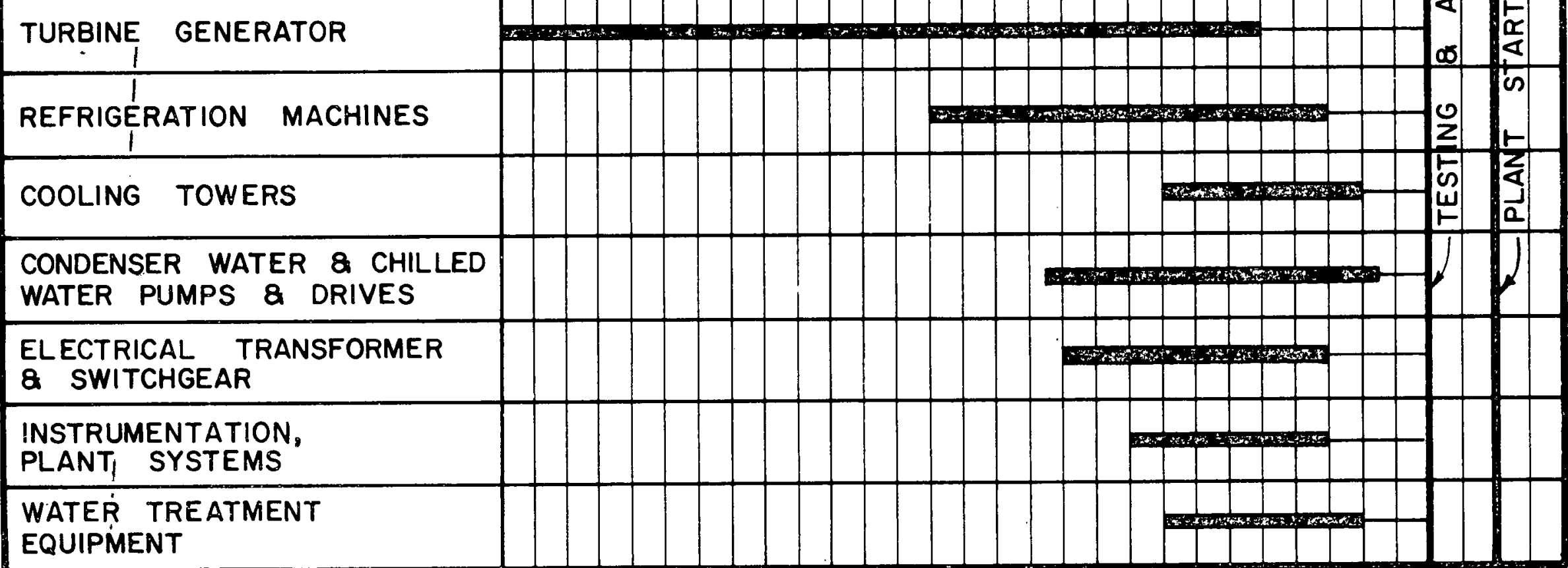




\section{1.b.2 PHASES IV, $V, V I$ \\ 1.b.2.1 Individual Work Packages}

Work will be accomplished and reports and deliverables furnished to DOE for each phase subsequent to Phase III in accordance with the following outline. Deliverables will be provided as indicated for each of the phases in the phase program schedule. (Parenthetical numbers indicate work task numbers on manpower schedules.)

a) Phase IV

\section{1) Construction Management}

Provide management for the construction of the Demonstration System. This task will include the planning, cost control and coordination of the various construction activities to ensure that the objectives are met and schedules are complied with.

Prepare a construction management plan, including procedures and schedules for accomplishing the procurement, installation and on-site construction activities.

Use DOE-designated procedure to control and maintain all drawings, and to furnish a notice of all authorized as-built changes to DOE.

Deliverables:

- Construction management plan (24)

- Implement management plan (25)

\section{2) Construction}

Construct the DOE-approved Demonstration System for the Demonstration Community, insuring that it is constructed in accordance with DOEapproved drawings and specification. This will include equipment purchase, component fabrication, site work, on-site construction, installation and operation. Such operation will meet the requirements of site-specific performance specifications and the construction drawings and specifications.

Deliverables:

- Evidence of the Demonstration System completion and compatibility. (26)

\section{3) Construction Reports}

Maintain and submit to DOE records and reports of deliveries, installation and construction of the Demonstration System.

The records and reports will include all as-built changes to drawings and specifications, and $35 \mathrm{~mm}$ slides of the construction site and plant. Changes in drawings will be submitted as accomplished. Slides and $8-1 / 2^{\prime \prime} \times 11^{\prime \prime}$ prints indicating significant progress will be filed with the daity construction logs and reports. The number and type of photo records will be coordinated with the Government Technical Re- 
presentative (GTR).

Deliverables:

- Records and reports of deliveries, installation and construction of the systems, slides, photos, daily construction logs, and changes in drawings. (27)

b) Phase V

1) Installation Test

Perform an installation test to verify that equipment installation and interconnections have been made in accordance with approved drawings. The test procedures will be performed in close cooperation with the GTR.

Deliverables:

- Installation Test Plan. (28)

- Testing, test reports and certification of installation in accordance with drawings and specification. (29)

\section{2) Start-Up Test}

Perform a start-up test in close coordination with the GTR to determine that the Demonstration System is functionally operative with normal or simulated consumers' loads. A detailed test plan for the start-up test will be developed and submitted to the GTR for approval at least thirty calendar days in advance of the major milestone scheduled date for the test. The approved test plan will be followed during the test unless exceptions are granted in writing by DOE and will be the basis for the test report to be submitted to DOE for approval. The approved test report will be used as a basis for interim acceptance of the plant. The GTR will be notified in advance of the start-up test in order to permit DOE to witness the test.

Deliverables:

- Start-up Test Plan. (30)

- Testing; test report, including statement of probable conformance with the site-specific performance specification.

3) Monitoring Instrumentation Procurement and Installation

Provide instrumentation sensors, signal conditioners and data acquisition system according to DOE-approved specifications. Design and specify the Monitoring Instrumentation System (MIS) which will be used in the Performance Tests and for subsequent data collection. Provide and install the instrumentation and monitoring system according to these specifications and the design of the Demonstration System. Instrumentation sensors and wiring will be shown on all as-built drawings and other applicable construction records. 
Provide interior space for the data acquisition system and install and make operable the complete instrumentation and data acquisition system. Permit DOE or its designee to perform a Monitoring Instrumentation Installation Test.

Deliverables:

- MIS Design and Specifications (32)

- DOE Approval (33)

- MIS-Procurement (34)

- MIS-Installation (35)

- DOE Test (36)

\section{4) Performance Test}

Make provisions for and assist DOE in carrying out performance tests for a period of a minimum of one year after an acceptable level of occupancy in the Demonstration Community has been achieved, to determine whether the performance of the Demonstration System satisfies the site-specific performance specifications.

Operate the Demonstration System during this period. (DOE will collect the data from the Monitoring Instrumentation System and prepare the resultant evaluations and analyses.) DOE will be provided with adequate operating space and facilities during the performance tests.

Prepare a test report describing the operational, maintenance and management aspects of the Demonstration System during the performance tests.

Grant DOE or its designee the right to temporarily install, in designated end-use systems, portable monitoring instrumentation and recording devices to evaluate building services utilization, and the right to install other monitoring instrumentation located in designated end-use systems to accomplish recording of data at a central station. The selection of designated end-use systems and buildings will be made by the GTR.

Permit access of DOE personnel and their guests to the Demonstration Community and the Demonstration System throughout the contract period of performance.

Del iverables:

- Report, including operating costs, operation and maintenance records, and management details of the Demonstration System, throughout the Performance Test. (37)

\section{c) Phase VI}

1) Operation and Maintenance Management

Operate and manage the Demonstration System throughout the life of 
the contract, in accordance with the written operation and maintenance management system as approved by DOE.

Del iverables:

- Operation and maintenance performance reports. (38)

2) Long-Term Demonstration Evaluation

In the event that DOE exercises its option to conduct a long-term demonstration evaluation of the performance of the Demonstration System continuing throughout the contract period of performance, including the optional periods: Manage, operate and maintain the system in accordance with the approved operation and maintenance manual during the demonstration evaluation periods. Maintain cost records and operation and maintenance logs; prepare interim reports and a final report containing management procedures, operating costs, and operation and maintenance records. Coordinate scheduling and preparation of those reports with the GTR. Provide DOE or its designee free access to the plant and designated buildings and such additional support as needed to allow observation of operating procedures, to permit maintenance of all elements of the MIS, and to obtain cost and operational information as needed to conduct the long-term demonstration evaluation. Make provisions to allow DOE to remove the data acquisition system and other major elements of the MIS at the conclusion of the demonstration evaluation period.

Deliverables:

- Interim and final reports, including operating costs, operation and maintenance records, and management details of the Demonstration System throughout the demonstration evaluation periods. (39)

3) Post-Contract Operation

Plan and prepare for continued satisfactory operation of the Demonstration Community and for good community relations concerning the

Demonstration System after conclusion of the contract period of performance.

Formulate and submit for DOE approval a comprehensive program plan detailing and scheduling tasks to assure that the Demonstration System will continue to furnish the designed services in as effective, safe, reliable and economic a manner as demonstrated in the evaluation period under the contract.

In the post-contract program plan, provide means to inform and coordinate the activities of Demonstration Community occupants and consumers to establish their support of the integrated community energy system concept.

Provide means for assuring compliance with federal laws relating to equal employment opportunity; develop and implement a plan to provide jobs, training and contracting opportunities for persons and local business concerns in the area of the site to the maximum extent feasible. 
Establish 1 iaison and programs necessary to establish and maintain effective relations with local utility companies, regulating groups, zoning authorities, environmental groups, and trade organizations and applicable levels of state and local government.

Provide continued reliable and adequate sources of fuel, supplies and maintenance for the Demonstration System.

Provide means to assure that the operation and maintenance manual procedures established under the contract will be diligently followed after contract expiration to insure continued environmental protection to the community as provided for in the design in accordance with the site-specific performance specifications.

Provide means for assuring adequate reimbursement or income for the system to assure that the plant can continue to function in a variable economic manner.

Not later than six months after start of the performance test, submit the post-contract program plan to the GTR for approval by DOE.

Following DOE approval of the program plan, implement those tasks to be commenced within the contract period of performance.

\section{Del iverables:}

- Program plan, including steps and procedures to assure viable Demonstration System operation after conclusion of the contract period of performance. (40)

d) Installation and Start-up Report

Prepare a report covering the design, construction, installation and operation of the Demonstration System from the time of contract start through the completion of the start-up test. Deliver to the GTR twenty. copies of a draft of this report, including findings and recommendations, within forty-five calendar days after completion of the system startup test. The report format will adhere to the requirements of the Government Printing office style manual. Within thirty days after receipt of GTR approval or comment on the draft report, which will be within thirty days after submittal by the Contractor, deliver twenty copies of the report, plus one reproducible copy, incorporating the GTR comments.

Deliverables:

- Report (41)

\section{1.b.2.2 PERT Charts}

The PERT network chart shows the time-task relationships which will be used to control and schedule work: 


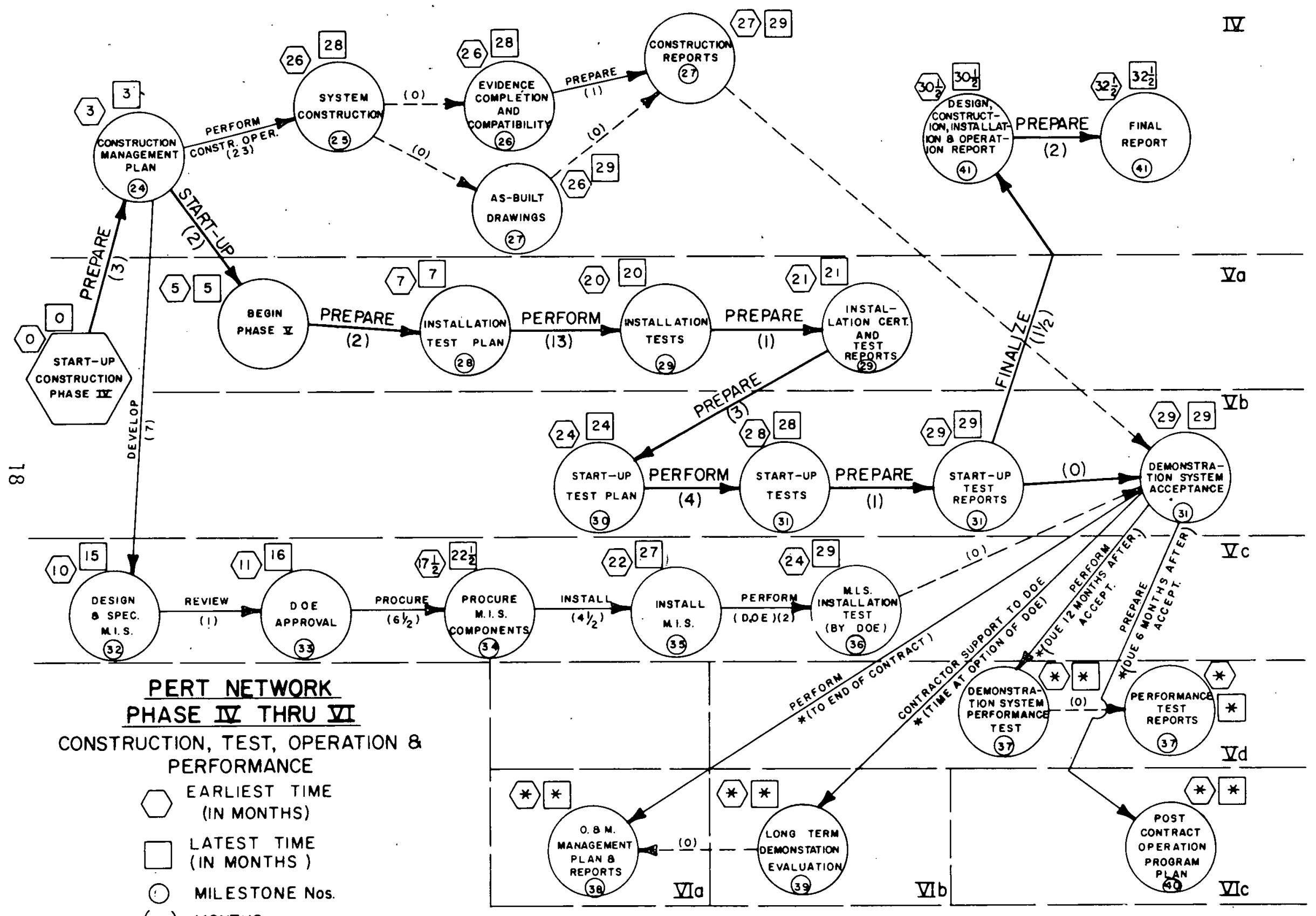




\section{1.b.2.3 Program Schedule}

A bar chart schedule, included herein, serves as a milestone chart and indicates time phases for each work task to be performed under the various phases of the program. 
HEAL G-C ICES-PHASES IV, $\boldsymbol{\nabla}, \mathbf{Z}$

PROGRAM SCHEDULE IN MONTHS

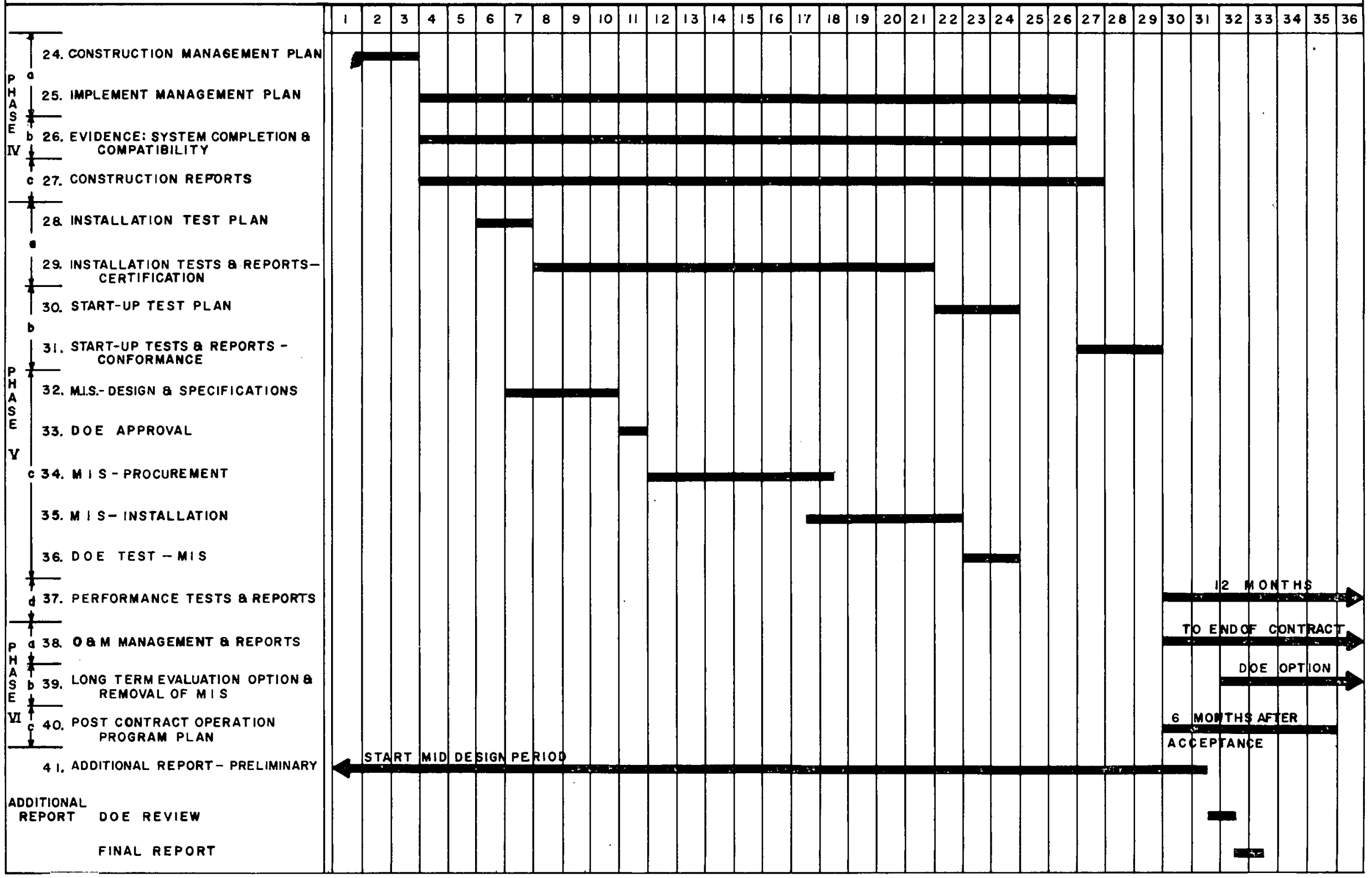


1.b.2.4 Cost Estimates

a) Phase IV

Man-month costs:

Work Task \# 24

Sub-Tota 1

General Legal

Public Relations

Travel

Per Diem

Printing

Total Estimated Cost

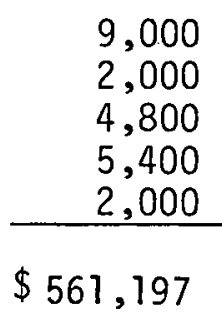

b) Phase V

Man-month costs:

Work Task \# 28

29

30

31

32

33

34

35

36

37

$$
\begin{array}{r}
\$ 11,263 \\
18,348 \\
23,780 \\
30,583 \\
23,842 \\
1,149 \\
5,939 \\
13,787 \\
2,928 \\
42,486 \\
\hline
\end{array}
$$

Sub-Total

Tests

Total Estimated Cost

$$
\begin{array}{r}
\$ 174,105 \\
2,400 \\
2,700 \\
32,000 \\
3,500 \\
\hline \$ 214,705
\end{array}
$$


c) Phase VI

Man-month costs:

Work Task \# 38

39

$\$ 20,822 /$ year $16,716 /$ year

40

$21,974 /$ year

Sub-Tota 1

$\$ 59,512 /$ year

Printing $5,000 /$ year

Total Estimated Cost

$\$ 64,512 /$ year

d) Installation and Start-up Report

Man-month costs:

Work Task \# 41

$\$ 63,142$

Printing 10,000

Total Estimated Cost

$\$ 73,142$

e) Cost Estimate Summary

Phase III

$\$ 1,251,635$

Phase IV

561,197

Phase V

214,705

Installation and Start-up Report

73,142

Total

$\$ 2,100,679$

Phase VI (Indeterminate Length)

$\$ 64,512$ per year 
f) Total Estimated Project Costs (1)

PHASE $\quad$ CONSTRUCTION

II I

IV

V

VI

Installation

\& Start-up

Report

TOTALS
-

$\$ 31,750,000$

725,000

(2)

(3)

150,000

(4)

$-$

$\$ 32,625,000$
DEMONSTRATION PROGRAM

$\$ \quad 1,251,635$

561,197

214,705

$64,512(5)$

73,142

$\$ \quad 2,765,19] \quad(6)$

(1) Does not include 1 and cost, estimated at $\$ 3,000,000$.

(2) Does not include DOE or NOPSI funding. See notes (3) and (4) below.

(3) Electrical grid-connecting. subsystem estimated cost, to be funded and constructed by NOPSI.

(4) MIS estimated cost. (funded by DOE).

(5) Estimated cost of one year; same estimated cost for each additional year.

(6) Includes $\$ 347,040$ funding by DOE. 


\section{1.b.2.5 Organizational Plan}

The organizational plan for management and scheduling of work is outlined in the following sections. Organization charts for the management team and for each participating Demonstration Team organization are included to show titles and areas of responsibility of key personnel. Manpower schedules show levels of effort in man-months for each of the work tasks under each phase.
a) Organization Charts

Following are five organization charts which define names, titles and responsibilities of all key personnel.

1) Project Management Team -- composed of key personnel from each of the Demonstration Team participants

2) HEAL

3) NOPSI

4) Kidde Consultants, Inc.

5) Orr-Schelen-Mayeron \& Associates, Inc. 


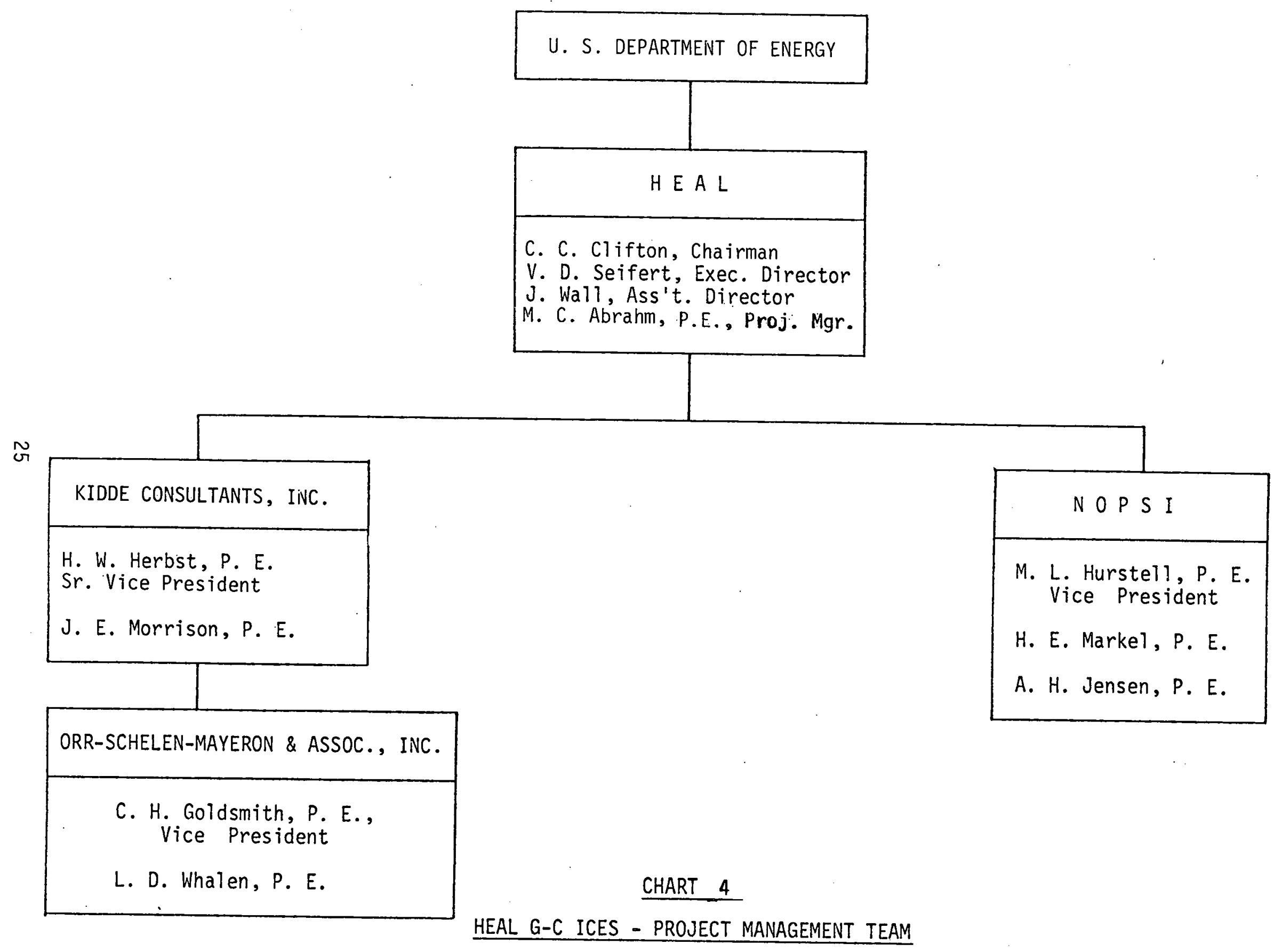




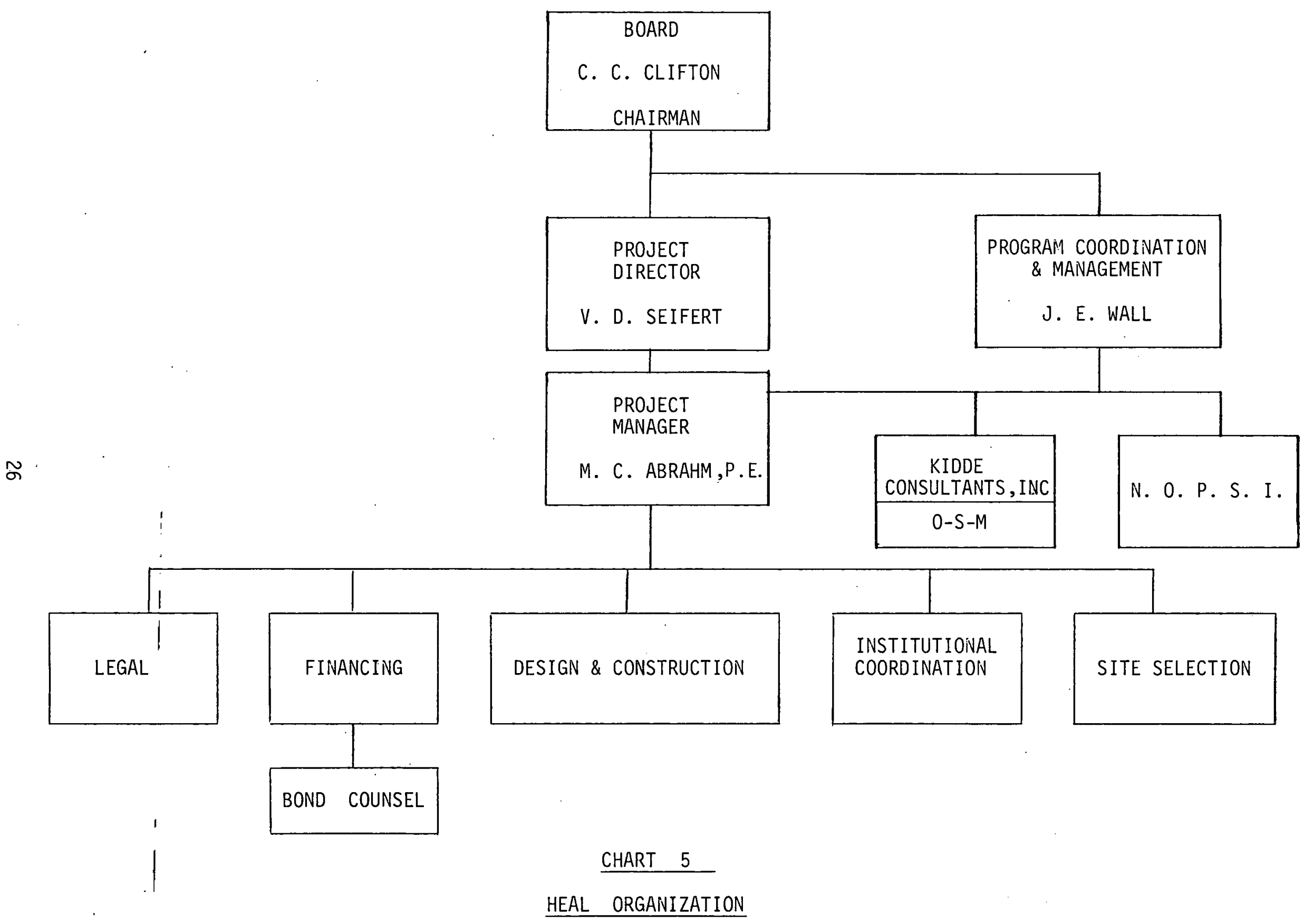




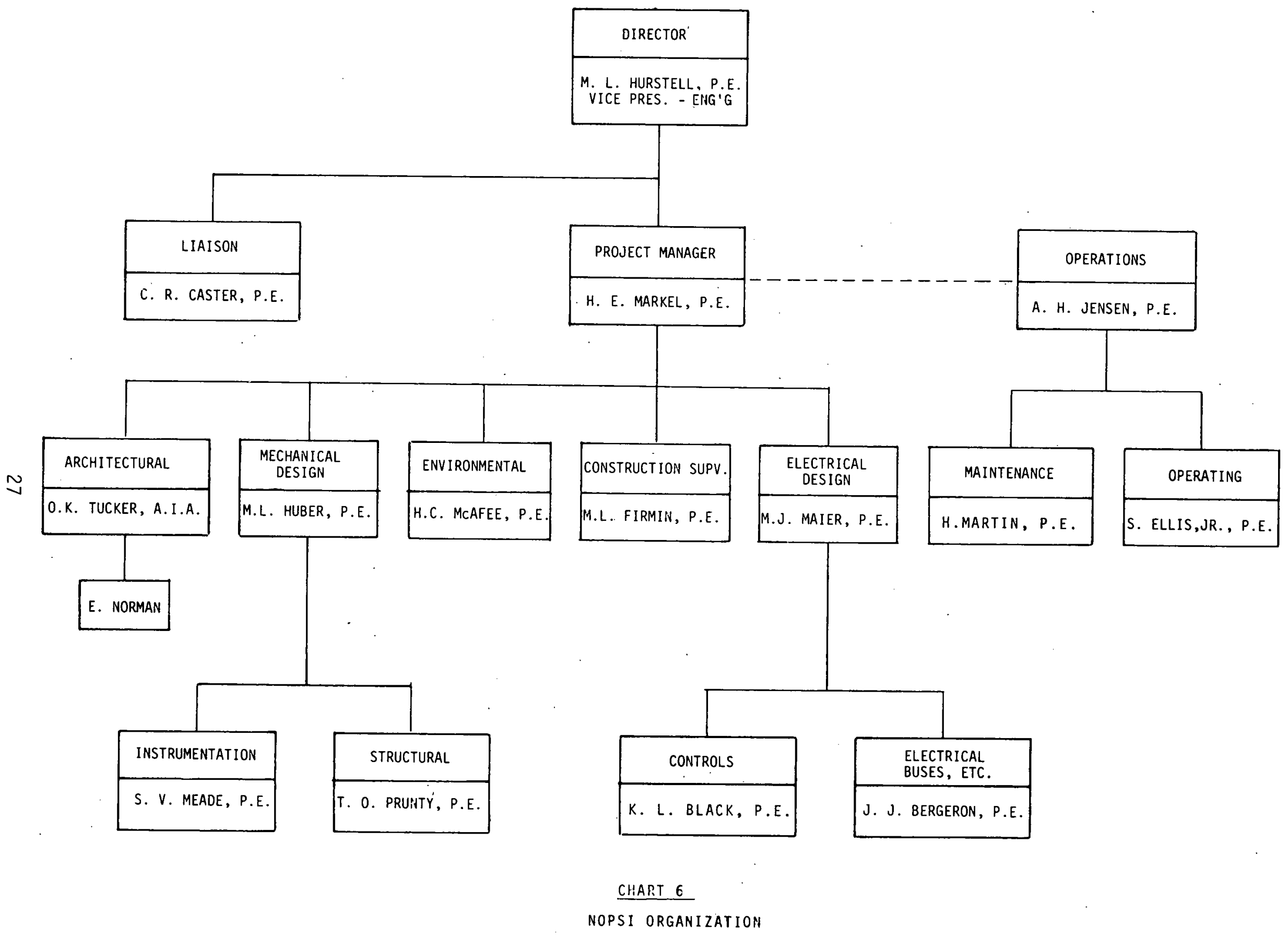




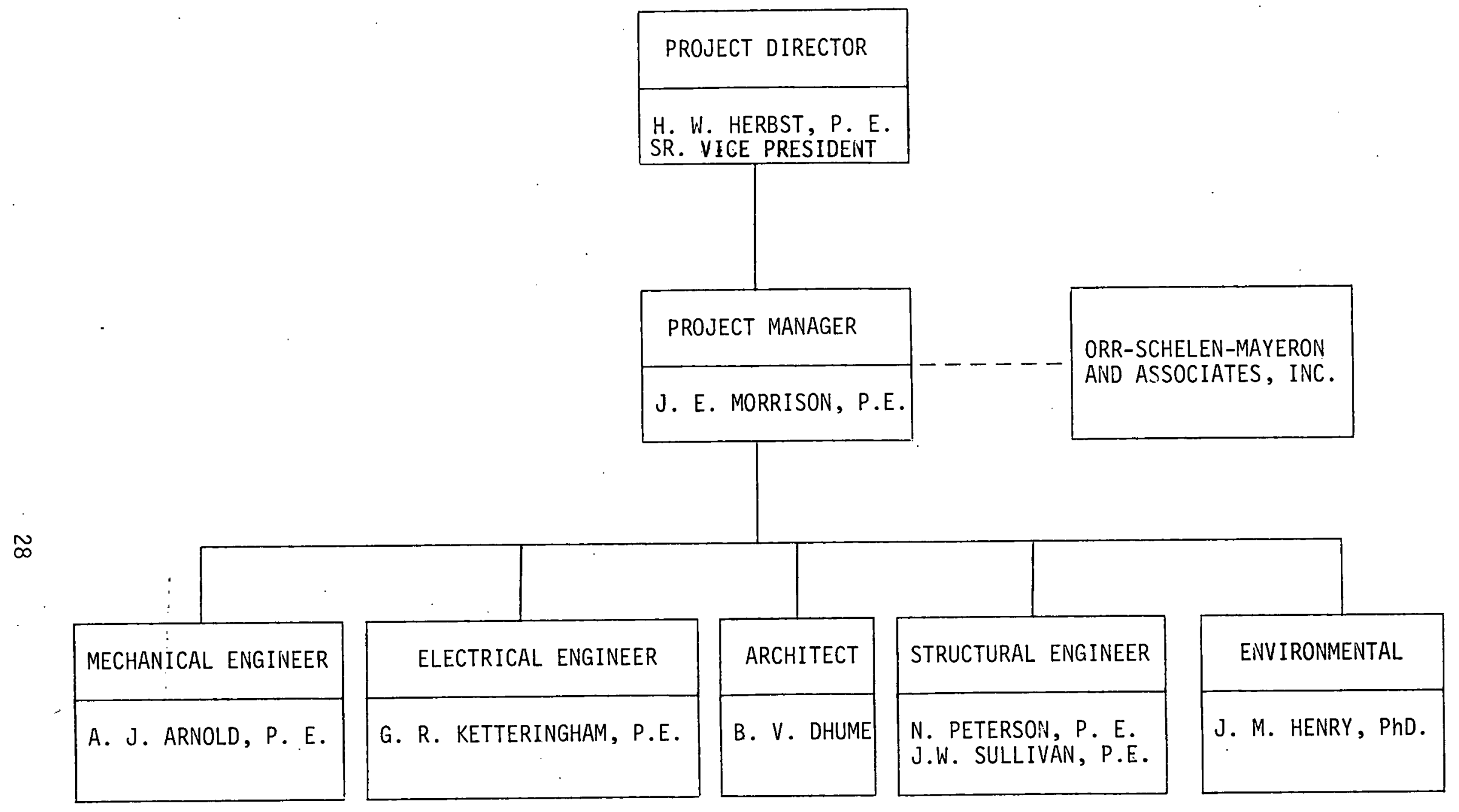

CHART 7

KIDDE CONSULTANTS, INC. 


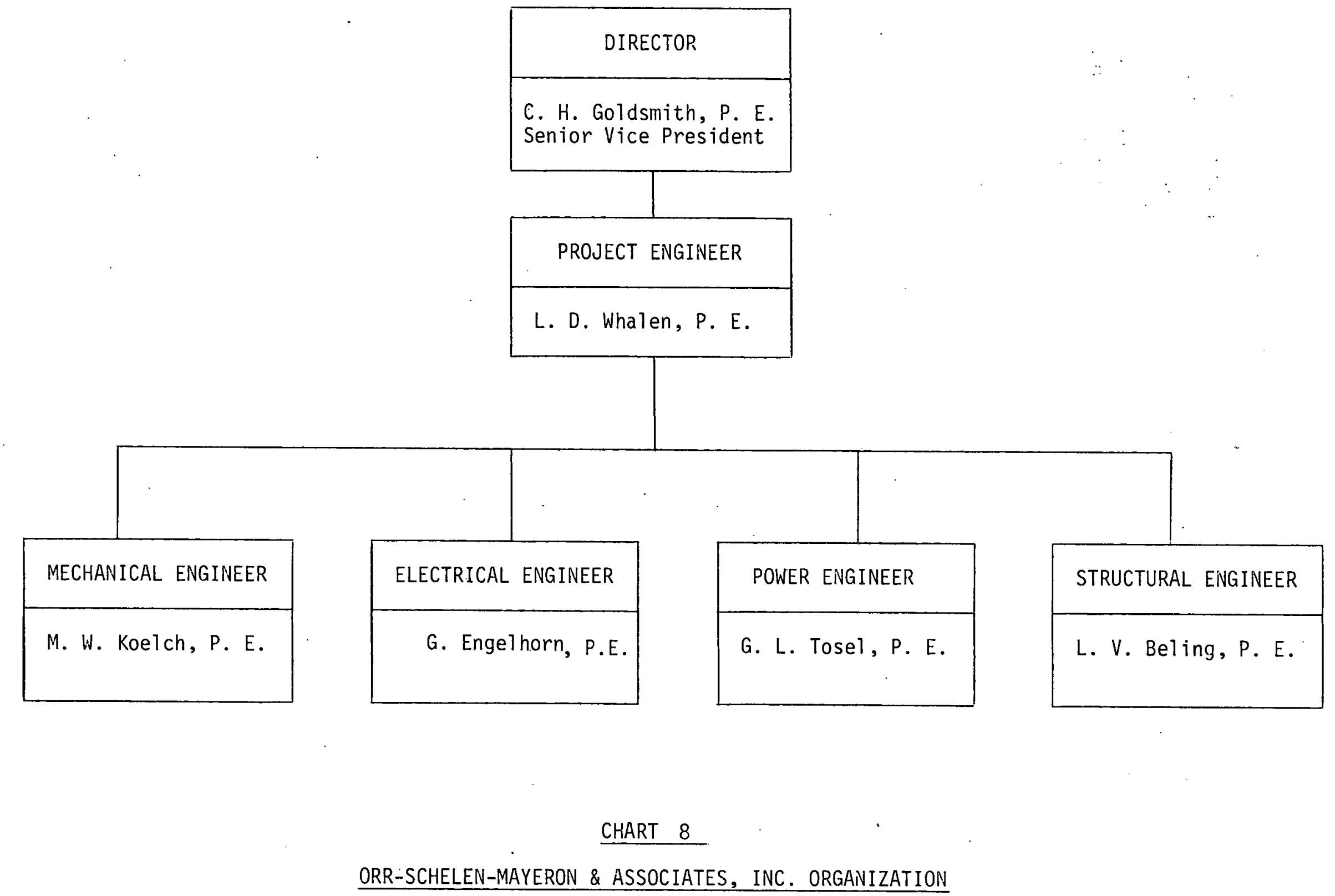


b) Key Personnèl \& Manpower Schedules

Titles, responsibilities and levels of authority of key personnel are indicated on the Organization Charts. Key personnel are listed on the Manpower Schedules for each phase of the project. The schedules were developed to indicate estimated levels of effort, in man-months, to be applied to each individual work task for each phase of the project. Totals are given for each phase and also indicate total man-months by task number and for each of the key personnel. 


\begin{tabular}{|c|c|c|c|c|c|}
\hline \multirow{2}{*}{ NAME } & \multicolumn{4}{|c|}{ WORK TASK NO. } & \multirow{2}{*}{$\begin{array}{l}\text { TOTAL } \\
\text { MAN } \\
\text { MONTHS }\end{array}$} \\
\hline & 24 & 25 & 26 & 27 & \\
\hline & & & & & \\
\hline $\begin{array}{l}\text { V. D. Seifert } \\
\text { J. E. Wall } \\
\text { M. J. Abrahm }\end{array}$ & $\begin{array}{l}0.10 \\
0.05 \\
2.00\end{array}$ & $\begin{array}{r}0.05 \\
0.02 \\
10.00\end{array}$ & $\begin{array}{l}0.01 \\
0.01 \\
2.00\end{array}$ & $\begin{array}{l}0.01 \\
0.01 \\
4.00\end{array}$ & $\begin{array}{r}0.17 \\
0.09 \\
18.00\end{array}$ \\
\hline
\end{tabular}

NOPSI
H. E. Marke1
1.00
2.00
0.50
0.80
4.30
M. L. Firmin (+ Staff)
M. L. Huber
$-$
7.00
3.00
34.00
M. J. Maier
$-\quad 4.00$
$-\quad 4.00$
0.25
2.00
6.25
4.00
0.25
2.00
6.25

KIDDE CONSULTANTS, INC.
H. W. Herbst
J. E. Morrison
G. R. Ketteringham
N. Peterson
H. A. Schomaker
G. J. Kelley

1.00

1.00

1.00

1.50

0.50

1.00

0.20
$0.50 \quad 0.00$

0.50

20.00

8.00

0.30
0.80
0.50
0.10
2.00
1.00

1.20

0.70

0.50

4.00

2.50

0.20

0.50

$-$

2.00
1.00

4.00

26.50

2.00

10.50

\section{ORR-SCHELEN-MAYERON}
C. H. Goldsmith
0.05
0.02
0.02
$0: 02$
0.11
L. D. Whalen
0.40
0.50
0.60
1.85
0.20
0.20
0.10
0.60
G. Engelhorn
0.20
0.30
0.10
0.10
0.70
L. V. Beling
0.10
0.08
0.08
0.12
0.38
M. W. Koelsch
0.10
0.10
0.10
0.06
0.36

82.77

9.72

21.42

121.06 
2) PHASE V

NAME

WORK TASK NO.

TOTAL

MAN

\begin{tabular}{lllllllllll}
\hline 28 & 29 & 30 & 37 & 32 & 33 & 34 & 35 & 36 & 37 & MONTHS
\end{tabular}

\section{HEAL}

V. D. Seifert

$\begin{array}{lllllllllll}0.01 & 0.01 & 0.01 & 0.02 & 0.02 & 0.01 & 0.01 & 0.01 & 0.06 & 0.02\end{array}$

J. E. Wall

M. C. Abrahm

$0.010 .010 .010 .01-0.010 .01-0.050 .01$

0.18

0.12

$\begin{array}{lllllllllllll}0.20 & 1.00 & 0.50 .1 .00 & 0.20 & 0.10 & 0.10 & 0.30 & 0.10 & 1.50\end{array}$

5.00

\section{NOPSI}

H. E. Markel

A. H. Jensen

M. L. Firmin

M. L. Huber

M. J. Maier

$\begin{array}{llllllllllllllll}0.10 & 0.30 & 0.30 & 0.10 & 0.10 & - & - & - & - & 0.50 & 1.40\end{array}$

$0.300 .501 .002 .500 .10-\quad-\quad-\quad-3.007 .40$

$-\quad-0.10-10-1.000 .200 .10-0.000$

$0.30 \quad 0.101 .000 .200 .10-\quad-0.05-0.35 \quad 2.10$

$0.10-1.000 .200 .10-\quad-0.05-0.351 .80$

KIDDE CONSULTANTS, INC.

H. W. Herbst

J. E. Morrison

G. R. Ketteringham

H. A. Schomaker

G. J. Kelley

J. M. Henry
0.50

0.10

0.10

0.10

- $0.10=$

$-0.10$
$0.100 .05 \quad 0.05-$

$\begin{array}{llllll}0.10 & 0.20 & 0.10 & 0.50\end{array}$

$0.05-$

$$
-
$$

$-$

0.10

0.50

0.100 .50

$\begin{array}{llll}1.00 & 0.20 & 1.00\end{array}$

$1.00-$

0.10 - -

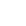

$-0.20$

0.20

0.10 $\begin{array}{lllllll}0.01 & 0.01 & 0.05 & 0.05 & 0.05\end{array}$

0.30

0.20

0.20

0.04

0.150 .30

0.050 .20

0.020 .20

0.20

0.05 $\begin{array}{ll}0.30 & 0.20 \\ 0.20 & 0.20\end{array}$

$0.20 \quad 0.30$

$0.20 \quad 0.20$

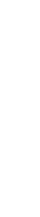

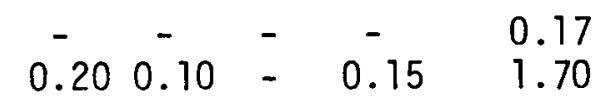

$\begin{array}{ll}- & 0.85 \\ 0.10 & 1.47\end{array}$

$0.10 \quad 1.47$

$-\quad 0.60$

$-\quad 0.21$

Technicians \& Draftsmen 
3) PHASE VI

\begin{tabular}{lllll}
\hline \multirow{2}{*}{ NAME } & \multicolumn{3}{c}{ WORK TASK NO. } & \multicolumn{1}{c}{ TOTAL } \\
\cline { 2 - 3 } & 38 & 39 & 40 & MAN \\
MONTHS
\end{tabular}

HEAL

V. D. Seifert

J. E. Wall

M. C. Abrahm

$\begin{array}{llll}- & - & 1.00 / y r & 1.00 / y r \\ 0.50 / y r & 0.50 / y r & 1.00 / y r & 2.00 / y r \\ 1.00 / y r & 1.00 / y r & 1.00 / y r & 3.00 / y r\end{array}$

NOPSI
A. H. Jensen (+ staff)
$3.00 / y r$
$2.00 / y r$
$2.00 / \mathrm{yr}$
$7.00 / \mathrm{yr}$

KIDDE CONSULTANTS, INC.
J. E. Morrison
$0.20 / y r$
$0.20 / y r$
$0.10 / \mathrm{yr}$
$0.50 / \mathrm{yr}$
G. R. Ketteringham
$0.20 / \mathrm{yr}$
$0.20 / \mathrm{yr}$
$0.10 / \mathrm{yr}$
$0.50 / \mathrm{yr}$

ORR-SCHELEN-MAYERON
C. H. Goldsmith
$0.25 / y r$
$0.15 / \mathrm{yr}$
$0.10 / \mathrm{yr}$
$0.15 / y r$
-
$0.10 / y r$
$0.05 / y r$
$0.35 / \mathrm{yr}$
J. H. Kunde
$0.10 / \mathrm{yr}$
$0.10 / \mathrm{yr}$
$0.40 / \mathrm{yr}$
$0.25 / y r$

TOTAL MAN MONTHS

$\begin{array}{cccc}5.40 & 4.25 & 5.35 & 15.00 \\ \text { per year } & \text { per year } & \text { per year } & \text { per year }\end{array}$


4) INSTALLATION AND START-UP REPORT

WORK TASK NO.

\section{NAME}

41

HEAL

V. D. Seifert

0.10

J. E. Wall

0.10

M. C. Abrahm

2.00

NOPS I

H. E. Marke1

4.00

KIDDE CONSULTANTS, INC.

H. W. Herbst

0.50

J. E. Morrison

0.50

G. R. Ketteringham

0.50

H. A. Schomaker

2.50

ORR-SCHELEN-MAYERON

C. H. Goldsmith

0.05

L. D. Whalen

0.50

J. H. Kunde

0.20

G. L. Tose1

0.20

G. Engelhorn

0.05

Technicians \& Draftsmen

2.00

TOTAL MAN MONTHS

13.20 
TASK II B

INSTITUTIONAL ISSUES, STAGE 2 
2.b. 1 HEAL-NOPSI LEASE-OPERATING AGREEMENT

A draft of the HEAL-NOPSI lease-operating agreement is included in this section. 
LEASE-OPERATING AGREEMENT

\title{
UNITED STATES OF AMERICA
}

\author{
STATE OF LOUISIANA
}

PARISH OF ORLEANS

AGREEMENT, dated , 19 _, between:

\section{HEALTH EDUCATION AUTHORITY OF LOUISIANA}

("HEAL"), a body corporate and public, constituting an instrumentality of the state of Louisiana, created and existing under the provisions of Act 112 of the regular session of the Legislature of Louisiana for the year 1968, (the "Act"), which Act now appears as R.S. 17:3051 to R.S. 17:3060, inclusive, being herein represented by its duly authorized to act herein and to execute this lease and Operating Agreement in HEAL's behalf by virtue of a resolution of said Board, a certified copy of which resolution is attached hereto and made a part hereof, and

\section{NEW ORLEANS PUBLIC SERVICE INC.}

("NOPSI") herein represented by its - duly authorized to act herein and to execute this Lease-operating Agreement by virtue of a resolution of its Board of Directors, a certified copy of which resolution is attached hereto and made a part hereof,

\section{W I T N E S.S E T H :}

WHEREAS, HEAL was created for the purpose of operating in New Orleans metropolitan area, a cooperative and coordinated multiinstitutional complex, (the "Medical Complex") that will serve to attract, encourage and assist public and private institutions and organizations that are dedicated to exemplary patient care, health science education, and biomedical research, and organizations, public and private, that will provide facilities and/or services deemed appropriate by it, and

WHEREAS, HEAL is further authorized to acquire land and to plan, construct and develop facilities for the use of the entities of the Complex; and

WHEREAS, after careful investigation and thorough study, HEAL has determined that a need exists for a grid-connected integrated community energy system to serve the members of the Medical Complex; and 
WHEREAS, said investigation and study indicated that the vacant ground located in the City of New Orleans and described in Exhibit " $A$ " attached hereto, would be the proper site upon which to construct the main plant and distribution system iand

WHEREAS, HEAL will acquire from the present owners of the Site good and merchantable title and shall acquire such servitudes and rights of way as may be necessary for the implementation of the Project; and

WHEREAS, On ,HEAL received a written request pursuant to section 5(H) of thé Act from the Primary Institutions to proceed with the planning, financing and construction of a gridconnected integrated community energy system on said site; and

WHEREAS, HEAL has retained engineers and consultants experienced in the planning and developments of energy facilities to assist it in determining the nature, type and size of the grid-connected integrated community energy system; and

WHEREAS, based upon the recommendations of its engineers, consultants and professional staff and its own independent study, HEAL has determined to undertake the construction of a grid-connected integrated community energy system; and

WHEREAS, as required by the Act and particularly section 5(H) thereof, HEAL held a public hearing on , 19 on the Project and thereafter determined that there is a public . need and necessity for such Project; and

WHEREAS, HEAL has retained the firm of ("Engineer") to prepare plans and specifications for the Project; and

WHEREAS, after careful deliberation, HEAI has determined that it would be in the public interest to lease the Project to an experienced and financially sound energy plant operator who could provide the management expertise and operational personnel to assure that the Project will be well and efficiently run and pay a rental sufficient to enable HEAL to finance the entire costs of the Project; and

WHEREAS, HEAL desires to raise the necessary funds to construct the Project through the issuance of revenue bonds payable from the rentals to be paid by the Lessee of the Project in the manner authorized by the Act; and

WHEREAS, NOPSI is willing to lease the project and make the payments hereinafter set forth in consideration of the undertaking on the part of HEAL to construct the Project and issue its bonds to finance the costs thereof; and

WHEREAS, NOPSI will secure requisite approvals from the Securities Exchange Commission for its entry into the business of furnishing steam and chilled water; and 
WHEREAS, NOPSI will procure acceptable long-term fuel supply contracts.

NOW, THEREFORE, for and in consideration of the premises and the mutual covenants hereinafter contained, the parties hereto hereby formally covenant, agree and bind themselves as follows, to-wit:

SECTION 1. Definitions.

Unless the context otherwise requires, the terms defined in this Section 1 shall, for all purposes of this Lease-operating Agreement and of any lease amendatory hereof or supplemental hereto, have the meanings herein specified, with the following definitions to be equally applicable to both the singular and plural forms of any of the terms herein defined:

"Act" means Act 112 of the Regular Session of the Legislature of Louisiana for the year 1968, now appearing as R.S. 17:3051 to R.S. 17:3060, inclusive.

"Bond Indenture" means the Resolution providing for the issuance of the Bonds to finance the Project which Resolution is incorporated herein by reference and a copy of which will be on file in the office of HEAL and the state Bond Commission and shall include all resolutions amendatory or supplemental thereof.

"Bond Fund" means the Bond Fund created and established by the Bond Indenture.

"Bonds" means the Bonds sold by the State Bond Commission for and on behalf of and in the name of HEAL pursuant to and in accordance with the Bond Indenture, payable from the revenues to be derived by HEAL from its ownership of the Project, including the payments to be made under the Lease, and equally and ratably secured by a. pledge of and lien on such revenues.

"Completion Date" means the date of completion of construction of the Project and installation of all machinery and equipment therein as that date shall be determined as provided in section 6 .

"Construction contract" means the contract or contracts providing for the construction of the project, a copy or copies of which will be on file in the office of HEAL.

"Construction Fund" means the construction fund created and established by the Bond Indenture.

"Fiscal Year" means the period beginning on July lst and ending on the next following June 30 th.

"Gross Receipts" means all income, revenues and moneys derived Jy the Lessee from its use, management and operation of the Project, including all income, revenues and moneys derived from the rates, rentals, fees and charges fixed, imposed and collected by the Lessee and arising out of its management and operation of the project or 
derived from the sale or rental of any commodities or goods in connection with the management and operation of the Project, less any sales, use, excise, occupancy or gross receipts taxes attributable to such receipts.

"HEAL" means the Health Education Authority of Louisiana created by the Act or if HEAl shall be abolished any board, body, commission, department or officers succeeding to the principal functions thereof or to whom the powers vested under the Act shall be given by law.

"Lease" means this Lease-Operating Agreement.

"Lease Term". means the duration of the leasehold estate created by this Lease, as specified in section 8 hereof.

"Lessee" means NOPSI.

"Lessor" means HEAL.

"Project" means the grid-connected integrated community energy system constructed pursuant to the plans and specifications referred to in section 3 hereof.

"Site" means that portion of the real estate upon which the main plant of the Project is to be constructed, and more particularly described on Exhibit "B" attached hereto.

"State" means the State of Louisiana.

SECTION 2. The Site.

The Lessor shall acquire the real property described on Exhibit " $A$ " attached hereto, on which it proposes to locate and construct the main plant of the Project.

Lessor shall acquire such servitudes and rights of way as shall be necessary for the implementation of the Project.

SECTION 3. The Project.

The Lessor proposes to construct the Project on the site and surrounding area with plans and specifications prepared by Engineer and approved by the parties hereto and the Commissioner of Administration, State of Louisiana and to cause the same to be operated and maintained as a support facility contemplated by the Act.

SECTION 4. Construction of the Project.

The Lessor shall cause the Engineer to proceed diligently to complete final plans and specifications for the Project, and upon approval thereof by the Lessor and the Lessee and the Commissioner of Administration, State of Louisiana shall proceed to award a Construction Contract or Contracts in accordance with the public contract Law of Louisiana for the construction of the project with a responsible contractor or contractors licensed to do business 
in the State of Louisiana and cause the Project to be constructed pursuant thereto and deliver the same to the Lessee as provided herein.

Lessor agrees that it will require strict compliance by said contractor or contractors with the terms of said Construction Contract or Contracts. If practical considerations during the course of construction require changes to be made in the plans and specifications therefor, Lessor may make such changes but only to the extent that funds are or will be available from proceeds of Bonds or other funds of the Lessor; provided, however, that the Lessor shall obtain the approval of the Commissioner of Administration and the Lessee for each change, the cost of which shall exceed $\$$

Notwithstanding any provision hereof, if at any time prior to the sale the bonds to finance the Project the Lessor shall determine not to proceed with the Project for any cause whatsoever, the Lessor shall have the right to so notify the Lessee, in which event this Lease shall terminate without liability to the parties hereto.

\section{SECTION 5. Financing of Construction of Project.}

The Lessor proposes to issue and sell its Bonds in an aggregate amount sufficient to enable it to pay the cost of constructing and equipping the Project in accordance with the plans and specifications of the Engineer and all costs associated with the issuance of the Bonds, the Bonds to be secured by certain revenues derived from take or pay service agreements between NOPSI and the Member Institutions of the Medical Complex passed through by NOPSI in the form of rentals to Lessor. Based upon studies, reports and detailed cost estimates developed and prepared by Engineer in conjunction with the professional staff and other consultants of HEAL, the parties hereto estimate such aggregate cost to be $\$$

The Bonds shall be sold pursuant to the Bond Indenture in the manner provided by the Act and the proceeds thereof, with the exception of accrued interest on the Bonds, deposited in the Construction Fund established by the Bond Indenture. Disbursements from the construction Fund will be used to defray the costs of acquiring, financing, constructing and equipping the project and Site, including in such costs: the cost of demolishing, removing or relocating any buildings or structures on the Site; costs of Site preparation; cost of installation of utility services or connections thereto or relocation thereof; costs of all labor, services, material, supplies, furnishing and equipment; financing charges; interest on the Bonds from their date to the date on which the first rentals are due; cost of architectural, engineering, legal, accounting and supervisory services, cost of publication, filing and recording; costs of plans, specifications, studies and surveys; cost of insurance, including title insurance; taxes and assessments; expenses incurred in enforcing any remedy against any contractor or subcontractor in respect of any default under any contract relating to the Project; and such other expenses as may be necessary or incident to the preparation of the site and the constructing 
and equipping of the Project thereon, the financing of such acquisition, preparation, construction and equipping and the placing of the Project in operation.

All moneys remaining in the Construction Fund after the Completion Date and after payment or provision for payment of all costs associated with the acquisition, financing, constructing, and equipping of the Project and Site shall be paid into the Bond Fund, except for amounts retained for payment of project costs not then due and payable.

SECTION 6. Establishment of Completion Date.

The Completion Date shall be evidenced by a certificate signed by the Engineer stating that, except for amounts retained for costs not then due and payable as provided in section 5 hereof:

(i) Construction of the Project has been completed in accordance with the plans and specifications therefor and all labor, services, materials and supplies used in such construction have been paid for and waivers of all liens have been obtained from all contractors and suppliers; and

(ii) All other facilities, machinery and equipment necessary in connection with the Project have been constructed, acquired and installed in accordance with the plans and specifications therefor and all costs and expenses incurred in connection therewith have been paid.

Notwithstanding the foregoing, such certificate shall be in accordance with the provisions of the Bond Indenture and shall state that it is given without prejudice to any rights against third parties which exist at the date of such certificate or which may subsequently come into being.

SECTION 7. Granting of Leasehold.

The Lessor hereby leases the Site and Project to the Lessee and Lessee leases from the Lessor the Site and the Project for the term and at the rental set forth herein subject to all terms and conditions hereof.

\section{SECTION 8. Effective Date of this Agreement: Lease Term.}

This Agreement shall become effective as of the date of its execution. Subject to the conditions specified in this paragraph, the term of this Lease shall commence on the first day on which steam or chilled water is available for delivery to all member institutions which participate in the Project. The term shall expire 30 years and 60 days after this date.

The Lessor shall exercise its best efforts and due diligence to expedite construction and to make the project available for operation by the Lessee on or before 
The Lessor hereby grants to the Lessee the right to take possession of and use and occupy prior to the completion date all portions of the project as soon as they are ready for use and occupancy.

If any liquidated damages are actually received by HEAL from the contractor or a surety on the contract for the construction of the Project, for failure to complete the project prior to , such amount shall be applied as a credit on the amount which will otherwise be owed as rentals to HEAL in succeeding payment periods.

\section{SECTION 9. Rentals.}

The Lessee shall pay to the Lessor rentals according to the following schedule which rentals shall commence accruing on the first day of the term of this Lease as set out in section 8: 
Al1 such payments with respect to percentage rentals may be based upon unaudited statements of Gross Receipts furnished to the Lessor by the Lessee or its agents and to the extent they are based upon unaudited statements shall constitute tentative payments. Final settlement of percentage rentals due Lessor shall be made upon statements prepared by independent certified public accountants.

Notwithstanding the foregoing, Lessee's obligation for rental payments shall be limited to amounts no greater than revenues received by it from the sale of steam and chilled water service in connection. with this Project less all expenses incurred by it (except rent payments), fees and service charges arising out of it being the Lessee of this Project.

SECTION 10. Manner and Place of Payment of Rentals

Each Rental Payment made hereunder shall be paid in lawful money of the United States of America to or upon the order of the depositary of the Bond Fund at its principal office in the city of New Orleans, or such other place as the Lessor may specify in writing to the Lessee. Each Rental

payment which is not paid when due shall bear interest at the rate of per annum from the date on which the payment becomes due until the same is paid. Until such time as the principal of and interest and applicable redemption premiums on the Bonds shall have been fully paid or provision for the payment thereof shall have been made in accordance with the Bond Indenture, the Lessee (i) will not suspend or discontinue any payments provided for in section 9 hereof, (ii) will perform and observe all of its other agreements contained in this Lease and (iii) will not terminate the Lease Term for failure of the Lessor to perform and observe any 
agreement, whether express or implied, or any duty, liability or obligation arising out of or connected with this Lease. Nothing contained in this section shall be construed to release the Lessor from the performance of any of the agreements on its part herein contained; and in the event the Lessor should fail to perform any such agreement on its part, the Lessee may institute such action against the Lessor as the Lessee may deem necessary to compel performance or recover its damages for non-performance so long as such action shall not do violence to the agreements on

the part of the Lessee. The Lessee may at its own cost and expense and in its own name, or the name of the Lessor, prosecute or defend any action or proceeding or take any other action involving third persons, including the general contractor, which the Lessee deems reasonably necessary in order to secure or protect its right or possession, occupancy and use hereunder, and in such event the Lessor hereby agrees to cooperate fully with the Lessee and to take all action necessary to effect the substitution of the Lessee for the Lessor in any such action or proceeding if the Lessee shall so request. Inspect.

SECTION 11. Lessee's Books, Records and Accounts: Right to

The Lessee shall keep and maintain at all times complete and accurate books, records and accounts relating to the management, administration, operation and maintenance of the Project. The. Lessor or the Legislative Auditor of the State of Louisiana shall have the right at all reasonable times to inspect, examine and audit all such books, records and accounts for the purpose of enabling the Lessor to determine the amount of the Gross Receipts of the Lessee and the accuracy of the statements made by the Lessee from time to time respecting the same. The Lessee shall cause its books, records and accounts relating to the Project to be audited annually. by an independent certified public accountant or firm of accountants, which audit may be the same audit as the regular annual audit of Lessee's books, records and accounts.

SECTION 12. Special Provisions With Respect to the Operation of the Project.

a) Fees, Rates and Charges: The Lessor shall establish and maintain a reasonable and proper schedule of fees, rates and charges for the providing of steam and chilled water service. Fees, rates and charges for such service shall be incorporated in the service contracts between NOPSI and the member institutions of the Medical Complex which participate in the Project. Such fees, rates and charges shall be set at such a level as to provide adequate revenue for purposes of securing the Bonds issued to finance the Project.

b) In the event that this lease is terminated for any cause, Lessee will continue to purchase the electricity produced by the Project which is not required to run the plant at the same value as embodied in the rates e'stablished for the sale of steam and chilled water service to the participating member institutions of the Medical Complex until the retirement of Lessor's bonded indebtedness for this Project. 
c) Gross Income Statement: Within twenty (20) days after the close of each month, the Lessee shall present to the Lessor or its nominee a statement, certified to by the Lessee, reporting the gross income for the prior month.

d) Advertising: Lessee shall be permitted without prior written approval of Lessor to post signs relating to its business in such locations and numbers as it deems proper so long as such signs conform to applicable laws and regulations of the city of New Orleans and the State of Louisiana.

e) Minimum Number of Employees on Duty: The Lessee shall have on duty at all times as many employees as are needed to insure prompt and efficient services to the public.

f) Assumption of Risk: The Lessor, its officers, agents and employees shall not be responsible or liable for any loss of, or damage to, the property of the Lessee or of his patrons while on the premises except as such may be caused by defects in the original design or construction of the Project, or by negligence of Lessor, its officers, agents and employees, or by Lessor's failure to abide by the covenants of this Agreement.

g) Compliance with Laws: The Lessee shall observe, perform and comply with all laws, statutes, ordinances, rules and regulations of the United States Government, the State of Louisiana, the City of New Orleans, or any department or agency of the above. No unlawful practices of any kind will be conducted on the premises.

The Lessee shall indemnify, save and hold harmless the Lessor against all actions, suits, damages and claims by whomsoever brought or made by reason of the non-observance, non-performance or noncompliance with the said laws, statutes, ordinances, rules or regulations except as such laws, statutes, ordinances, rules or regulations apply to the design or construction of the project or financing of same. Indemnification shall not be had for criminal penalties.

h) Maintenance and Clean-Up: The Lessee shall be responsible for the routine maintenance, clean-up, and care of the project and the Site, and shall maintain the building throughout the lease period in its condition at the commencement; normal wear and tear excepted. Property replaced by equipment or other material at Lessee's expense shall belong to Lessee.

i) Major repairs and extraordinary maintenance not covered by the insurance provided for in section 19 shall be made at the expense of HEAL. Major repairs shall be defined as

shall be defined as

Property replaced by equipment or other material at the expense of. Lessor shall belong to Lessor; provided, however, if such property shall be sold, Lessor shall deposit the proceeds of such sale in the Bond Fund to be used either for the payment of principal and interest on the Bonds or the redemption of such Bonds as are then subject to redemption. 
j) Employees: The Lessee shall employ only persons of good moral character and possessed of requisite skilis.

k) Inspection: The Lessor shall have the right at all reasonable times to enter the Project for the purpose of examining the state of repair and condition of the premises and the equipment, and for the purpose of determining whether the terms, covenants and conditions contained in the lease are being fully and faithfully observed and performed.

1) Independent Contractor: The Lessee is deemed to be an independent contractor and not the agent, servant, representative or employee of the Lessor.

m) Steam and chilled water shall remain the property of NOPSI until disposed of by it.

n) Lessor shall co-operate in every respect with Lessor in the fulfillment of its committments to the institutions served by the Project.

\section{SECTION 13. Taxes and other Governmental Charges.}

Lessor and the Lessee understand that under present law no part of the Project owned by Lessor will be subject to ad valorem taxation by Louisiana or by any political or taxing subdivision thereof, and that under present law the income and profits, if any, of Lessor from the Project are not subject to either Federal or Louisiana taxation. However, the Lessee will pay, as the same respectively become due, all taxes and governmental charges of any kind whatsoever, including ad valorem taxes, that may at any time be lawfully assessed or levied against or with respect to the Project or any machinery, equipment or other property installed or brought by the Lessee therein or thereon (including, without limiting the generality of the foregoing, any taxes levied upon or with respect to the income or profits of Lessor from the Project which, if not paid, would become a lien on the Project or a charge under the Bond Indenture thereon and the pledge or assignment thereof to be created and made in the Bond Indenture), all utility and other charges incurred in the operation, maintenance, use, occupancy and upkeep of the project and all assessments and charges lawfully made by any governmental body for public improvements that may be secured by a lien on the Project; provided, that with respect to special assessments or other governmental charges that may lawfully be paid in installments over a period of years, the Lessee shall be obligated to pay only such installments as are required to be paid during the Lease Term.

That Lessee may, at its expense and in its own name and behalf or in the name and behalf of Lessor, in good faith contest any such taxes, assessments and other charges and, in the event of any such contest, may permit the taxes, assessments or other charges so contested to remain unpaid during the period of such contest and any appeal therefrom unless during such period enforcement of such contested item is being prosecuted and has not been effectively stayed, and unless by nonpayment of any such items the lien of the 
Bond Indenture as to any part of the Project will be materially endangered or the Project or any part thereof will be subject to loss or forfeiture, in which event such taxes, assessments or charges shall be paid promptly or secured by posting a bond, in form satisfactory to Lessor. Lessor will cooperate fully with the Lessee in any such contest. In the event that the Lessee shall fail to pay any of the foregoing items required by this section to be paid by the Lessee, Lessor may (but shall be under no obligation to) pay the same and any amounts so advanced therefor by Lessor shall become an additional obligation of the Lessee to the one making the advance, which amounts, together with interest thereon at the rate of six percent (6\%) per annum from the date thereof, the Lessee agrees to pay. The Lessee may at its expense and in its own name and behalf or in the name and behalf of Lessor apply for any tax exemption allowed by the state of Louisiana or any political or taxing subdivision thereof under any existing or future provision of law which grants or may grant such tax exemptions.

Lessor agrees that the Lessee shall be entitled to all investment tax credit permitted under state and federal laws with respect to the Project and Lessor will fully cooperate with Lessee in the taking by the Lessee of all such investment tax credit.

SECTION 14. Management, Operation, Maintenance and Utilities.

During such times as the Lessee is in possession of the Project and the site, the management, operation and maintenance of, and the supplying of all utility services to, the project and the site shall be the responsibility and at the expense of the Lessee. This shall include, but not be limited to, salaries and wages, costs of materials and supplies, costs of reasonable security measures, custodial and janitorial services, telephone, light, heating, air conditioning, water, sewer, and all other public utility services necessary for the proper operation and maintenance of the Project. The Lessee at its own expense (i) will maintain, or cause to be maintained, and will keep, or cause to be kept, the Project and the site in a state of good operating condition; and ( $i$ ) will make or cause to be made all necessary and proper repairs and renewals thereto and replacements thereof resulting from or required by ordinary wear and tear, or want of care, on the part of the Lessee or other cause. The Lesree will not permit or allow any waste with respect to the Project or the site.

It is understood and agreed that in consideration of the payment by the Lessee of the rental herein prescribed, the Lessor is obligated to provide to the Lessee only the Project and the Site, and the Lessor shall have no obligation to incur any expense of any kind or character in connection with the management, operation or routine maintenance of the project and site during the term of this Lease. 
SECTION 15. Right of Entry and Delivery of Possession.

During the period of construction prior to the commencement of the Lease Term, the Lessee shall have the right of access (i) to the site at all reasonable times for the purposes of inspection and (ii) to the site and the Project for the purposes of installation of its own equipment and furnishings if it will not interfere with such construction. The Lessor agrees to deliver the Project and the site to the Lessee when the Project has been completed to the degree that it is ready for use and occupancy. After the Lessee has taken possession of the Project, the Lessor or its designees shall have the right to enter the Project and upon the Site during and at all reasonable times (and in emergencies at all times) (i) to complete construction of the Project, (ii) to inspect the Project and the site, (iii) for any purpose connected with the Lessor's rights or obligations or the Lessee's obligations under this Lease, (iv) to exhibit the same to prospective tenants in the event of the default of the Lessee hereunder and (v) for all other lawful purposes.

\section{SECTION 16. Additions and Improvements.}

Except as modified by the provisions of section 12 (d) hereof, subject to the prior written approval of the Lessor, the Lessee shall have the right during the term of this Lease to make additions or improvements to the Project and Site, to attach fixtures, structures or signs, and to affix any personal property to the improvements on the Project, provided the use of the Project for the purposes contemplated in this Lease are not impaired.

\section{SECTION 17. Discharge of Liens by Lessee.}

The Lessee shall keep the Project and the site and all improvements thereto free and clear of all liens, charges and encumbrances. The Lessee agrees to pay, when due, all sums of money that may become due for, or purporting to be for, any labor, services, materials, supplies, utilities or equipment furnished to or for the Lessee (whether by reason of the compliance by the Lessee with the provisions of this Lease or otherwise) in, upon or about the site and the Project or either of them and which may be secured by any mechanic's, materialmen's or other lien against the Project, the Site, and the Lessor's interest therein, or any of them, and will cause each such lien to be fully discharged and released at the time the performance of any obligation secured by any such lien matures or becomes due; provided, however, that if the Lessee desires to contest any such lien, it may do so, (i) if the Lessee prior to any such contest shall first furnish the Lessor indemnity in form and amount satisfactory to the Lessor against any loss or liability by reason of such contest or lien and shall effectively prevent foreclosure or enforcement thereof, and (ii) if and so long as such contest or proceeding shall stay the execution or enforcement or foreclosure of such lien, and if so stayed and said stay thereafter expires, then and in any such event the Lessee shall forthwith pay and discharge such lien. 
SECTION! 18. Use of Site and Project; Compliance with Laws.

The Lessee does hereby covenant and agree that it will use the Project to provide steam and chilled water for the Medical Complex and produce by-product electricity. The Lessee agrees that it will promptly comply with all valid statutes, ordinances, laws, judgments, decrees, regulations, directions or requirements of any governmental authority, now and hereafter applicable to, and having jurisdiction of, the site, the Project or any adjoining public ways, as to the manner of use or condition of the Project, the site or adjoining ways including by all appropriate or required repair, improvement, replacement or maintenance procedures; provided the Lessee may, in good faith and in due diligence, contest any such governmental requirement, even though such contest may result in the imposition of a lien or charge against the Project and Site, (i) if the Lessee shall first furnish the Lessor indemnity in form and amount satisfactory to the Lessor against any loss or liability by reason of such contest or by reason of such lien or charge, and shall effectively prevent foreclosure or enforcement thereof, and (ii) if and so long as such contest or proceeding shall stay the execution of enforcement or foreclosure of such lien or charge, and if so stayed and said stay thereafter expires, then and in any such event the Lessee shall forthwith pay and discharge such lien or charge. The Lessee shall not perform, or permit others to perform, any work on the site or Project relating to any repairs, renewals, replacements, rebuilding or alterations thereof unless the Lessee shall have first procured any required governmental permits and unless such work shall be performed in compliance with all applicable building, zoning and other laws, ordinances and governmental regulations and requirements, and in accordance with the requirements, rules and regulations of all insurers of the Project. The Lessor agrees to join in the application for any required permits and authorjzation whenever application by it is required for such permits or authorizations.

\section{SECTION 19. Insurance Required.}

For the purposes of this section the terms "Construction Fund", "Construction Period" and "Net Proceeds" shall have the respective meanings set forth in the last paragraph of this section.

During any Construction Period the Lessor shall keep, or cause the contractor with respect thereto to keep, and thereafter and throughout the term of this Lease, the Lessee shall keep, the Project continuously insured with responsible insurers against such risks as are customarily insured against by owners of facilities of like size and type, paying, as the same become due and payable all premiums in respect thereto provided that during any Construction Period the costs of such insurance may be paid from the Construction Fund. Such insurance shall include, but not necessarily be limited to, the following:

(a) Insurance against loss or damage by fire and lightning, with uniform standard extended coverage endorsement limited only as may be provided in the standard form of extended coverage endorsement in use in Louisiana at the time, and 
with standard vandalism and malicious mischief endorsement. The amount of such insurance to be procured and maintained shall be the greater of (i) insurance upon a repair or replace basis if available, and otherwise to the full insurable value of the insured property, as determined by a recognized appraiser or insurer selected by the Lessor and approved by the Lessee or (ii) the amount which would be required to pay or redeem all Bonds from time to time outstanding, including any premiums payable upon such redemption and interest on such Bonds to the redemption date, plus an additional amount equal to the cost reasonably estimated by the Lessor of clearing the site in the event the damage was not restored. Loss or damage by earthquake shall also be insured, if such insurance is available, but this peril may be subject to a deductible not exceeding $\$$ applying to each loss.

(b) If and when war damage insurance is obtainable from the United States of America or any agency thereof or any corporation formed by the United States Government, policies of war damage insurance shall be obtained by the Lessee on the Project. The amount of such war damage insurance to be procured and maintained shall be the greater of (i) the maximum coverage obtainable, or (ii) an amount equal to the principal amount of the Bonds from time to time outstanding and any premiums payable upon their redemption from the proceeds of such insurance and interest on such Bonds to the redemption date, plus an additional amount equal to the cost reasonably estimated by the Lessor of clearing the site in. the event the damage was not restored, subject in either case to a $\$$ deductible for each loss.

(c) Comprehensive insurance for protection of the Lessor and the Lessee and their respective members, officers, agents, servants and employees, insuring said parties against liability for damages because of personal injury (including Workmen's Compensation Claims), death or damage to property occuring on or in any way related to the Project or any part thereof or occasioned by reason of the operations of the Lessee upon, in and around the Project, with insurance of $\$$ f__for bodily injury or death to one person, \$_for bodily injury or death to more than one person, per occurrence, and $\$$ damage, per occurrence, (or such greater amount as may be determined by the Lessee). Such policies shall cover the entire project and any elevators or escalators therein, and any sidewalks, streets or other public ways adjoining the Project.

The Lessee shall during the Lease Term procure and maintain Erom responsible insurers rental insurance, or use and occupancy insurance, or business interruption insurance to cover loss, total or partial, of the use of the Project and other improvements on the Site as the result of any fire, explosion, vandalism, 
malicious mischief, other hazards normally covered by extended coverage endorsement, earthquake, tornado, hurricane and sprinkler leakage, in such amounts that, in case of a loss of the use of the Project or any part thereof, the proceeds of such insurance in the event of loss will be sufficient to pay amounts due on bonded indebtedness for the period they are not usable, up to a maximum period of thirty-six (36) months or to the fullest extent available if such maximum amount cannot be obtained.

The provisions of this section as to insurance required to be procured and maintained shall not limit or prohibit, or De construed as limiting. or prohibiting, the Lessor or the Lessee from obtaining any other insurance with respect to the Project or the use and occupancy thereof that either or both of them may wish to carry, but in the event the Lessor or the Lessee, as the case may be, shall procure or maintain any such insurance not required by this section, the cost thereof shall be at the expense of the party procuring or maintaining the same.

Beginning with the Lease Term the Lessor and the Lessee shall furnish to each other (i) policies or certificates of the insurers showing the amount and type of the insurance then in effect that has been procured and maintained pursuant to this section and stating the date and term of the policy evidencing such insurance and, with respect to the liability insurance required by clause (c) of the second paragraph of this section, that such liability policy or policies insures the Lessee against the liability of the Lessee assumed by it under section 31 hereof, to the extent that such liability is insurable, and (ii) certificates that the insurance so procured or maintained by the Lessor or the. Lessee, as the case may be, comply as to amounts and types with requirements of this section. Certificates evidencing any renewals of the aforesaid insurance, or evidencing that such insurance is no longer required by the Lease, shall be delivered not less than thirty (30) days prior to the expiration of any policy of insurance replaced or extended by the insurance represented by such certificate. All policies of insurance shall provide for not less than thirty (30) days' notice to the Lessor and the Lessee before such policy may be cancelled.

All insurance required by clauses (a) and (b) of the second paragraph of this section shall be taken out and maintained in the name of the Lessor and the Lessee, as insureds, in generally recognized responsible insurance companies selected by the Lessor and acceptable to the Lessee. All policies evidencing such insurance shall provide for payment of the losses to the Lessor and the Lessee as their respective interests may appear; provided that, during a Construction Period any builder's risk insurance carried pursuant hereto may provide for payment to the Lessor, the Lessee, or the contractor as their respective interests may appear. Such policies shall contain standard mortgagee or lender's clauses. Any Net Proceeds 
of Insurance required by said clauses (a) and (b) received during a Construction Period shall be deposited in the Construction Fund and any Net Proceeds of Insurance received during any time other than a construction Period shall be held by the depositary of the Bond Fund established by the Bond Indenture in a separate and special bank account and in trust for the benefit of the holders of the Bonds if any Bonds are then outstanding, to be applied in accordance with the provisions of this section. The Lessor shall collect, adjust and receive all moneys which may become due and payable under any such policies and may compromise any and all claims thereunder and shall use and apply the proceeds of such insurance as provided in the Lease, and the Lessor shall be fully protected in accepting payment on account of such insurance or any adjustment, compromise or settlement of any loss agreed to in good faith by it.

The Net Proceeds of the insurance carried pursuant to this Section shall be applied as follows: (i) the Net Proceeds of the insurance required by.clauses (a) and (b) of the second paragraph of this section shall be applied as provided in Section 20 of the Lease; (ii) the Net Proceeds of insurance required by clause (c) of the second paragraph of this section shall be applied toward iextinguishing or satisfying or remedying the liability, loss or damage with respect to which such proceeds may be paid, and ( $i i i)$ the Net Proceeds of insurance required by the third paragraph of this section shall be paid into the Bond Fund and Lessee shall be given credit against its rental payments for the amount of money paid into said Fund.

For the purposes of this section and section 20 hereof, the following terms shall have the following meanings:

"Construction Fund" means any fund of that name created in or under the Bond Indenture.

"Construction Period" means (i) with respect to the original construction and equipping of the Project, the period between the beginning of the construction of the Project and the Completion Date with respect to such construction and equipping, and (iii) with respect to any reconstruction or restoration, the period between the beginning of such reconstruction or restoration or the date on which any Net proceeds are received (whichever is earlier) and the Completion Date with respect to such reconstruction or restoration.

"Completion Date" means (i) with respect to the original construction and equipping of the Project the date of completion of the construction of the Project, including the installation therein of all machinery and equipment called for by the plans and specifications :or the Project, and (ii) with respect to reconstruction or restoration of the Project, the date of completion of such reconstruction or restoration, including the 
installation of any machinery or equipment incidental to such reconstruction or restoration.

"Net Proceeds" means the gross proceeds from the insurance with respect to which that term is used remaining after payment of all expenses (including attorneys' fees) incurred in the collection of such gross proceeds.

\section{SECTION 20. Damage and Destruction.}

If the Project is damaged or destroyed by fire or other casualty, the Lessee (or the Lessor, at the Lessee's direction), (i) will promptly repair, rebuild or restore the property damaged or destroyed to substantially the same condition as existed prior to the event causing such damage or destruction with such changes, alterations and modifications (including the substitution and addition of other property exclusive of land) as may be desired by the Lessee and as will not impair operation unity or the revenue producing capability of the Project or the character of the Project as a public facility, and (ii) will apply for such purpose so much as may be necessary of any Net proceeds (as defined in the last paragraph of section 19 hereof) of insurance resulting from claims for such losses; provided the Lessee shall be obligated to rebujld, repair or restore the property damaged or destroyed only to the extent of the Net Proceeds of insurance made available to it for such purposes or the requisite additional moneys therefor are available to the Lessee from Lessor.

\section{SECTION 21. Expropriation.}

If the Project and the site or either of them or any part thereof or any interest therein is expropriated or taken as a result, or in anticipation, of the exercise of the right of expropriation or eminent domain, the provisions of this section shall apply, and, for the purposes of this section, the terms, "Award of both parties hereto", "Lessor's Gross Award", "Lessee's Gross Award", "Lessor's Net Award" and "Lessee's Net Award" shall have the respective meanings set forth in the last paragraph of this section.

In the event the whole, substantially the whole of the project or enough of it to make reconstruction of a similar functioning unit unfeasible is so taken while any Bonds are outstanding, then there shall be paid into the Bond Fund all or so much of the Award of both parties hereto as shall be required, together with any other monies then held in the Bond Fund or otherwise held under the Bond Indenture or held for the Lessor and available therefor, to pay or redeem all the then outstanding Bonds on the first practicable date. thereafter on which the same may be paid or redeemed in accordance with their terms, and such Award and such monies shall be applied to such payment 54 and redemption on such date. 
If the amount of the Award of both parties hereto, together with such other monies available therefor is in excess of the amount required to pay or redeem all the then outstanding Bonds on the first practicable date thereafter on which the same may be paid or redeemed in accordance with their terms, such excess shall be paid to the Lessor and the Lessee in proportion that the Gross Award of each party bears to each other. Upon deposit of the Awards in the Bond Fund in an amount to satisfy the requirements of the first sentence of this paragraph with respect to the payment or redemption of all the then outstanding Bonds, the lease shall forthwith cease and terminate, and the parties hereto shall be released and discharged of and from all further obligations hereunder without prejudice, however, to any claims which may have accrued prior thereto in favor of either party against the other.

In case less than the whole or substantially the whole of the Project shall be so taken, then Lessor shall if possible on the remainirg area restore the remaining portion so that the same will constitute a functioning grid-connected integrated community energy system, and the Lease shall continue in full force and effect; provided that Lessor shall not be required to expend any monies for such restoration in excess of the total of Lessor's Net Award and Lessee's Net Award, and the cost of such restoration shall be paid out of the total of Lessor's Net Award and Lessee's Net Award. In case the total of such Net Awards shall exceed the cost of such restoration and if at the time of completion thereof any Bonds shall remain outstanding, then such excess shall be deposited in the Bond Fund provided that if such excess exceeds $\$$ and any Bonds are then subject to redemption in accordance with their terms, such excess shall be applied to the redemption of such Bonds. If such excess shall be more than sufficient to pay or redeem all outstanding Bonds, then the balance thereof remaining after the payment or redemption of such Bonds shall be divided between Lessor and Lessee in the proportion which their respective Net Awards shall bear to each other.

In case the use, for a limited period, of all or part of the Project shall be expropriated or taken by condemnation or in the exercise of the right of eminent domain, then the Lease shall not be thereby terminated and the parties shall continue to be obligated under all of its terms and provisions. If such taking is for a period of time ending on or prior to the expiration of the Lease Term hereof, the Lessee shall be entitled to receive and retain the amount of the Award of both parties made for such taking whether by way of damages, compensation, rent or otherwise, and Lessee in such case shall, at the termination of the period of such taking, restore the project as nearly as may be possible to the condition existing immediately prior to such taking. If such taking is for a period which extends beyond the expiration of the Lease Term hereof, Lessee shall be entitled to receive and retain that portion of the entire Award of both parties which shall be allocable to the 
period of time from the date of such taking up to the date of such expiration of the Lease Term hereof and Lessor shall be entitled to the remainder of such Award.

The parties shall cooperate fully with each other in the handling and conduct of any prospective or pending expropriation or condemnation proceeding. It is further expressly understood and agreed that each of the parties hereto shall have the free and unrestricted right to be represented by counsel in, or in anticipation of or preparation for, any such expropriation or condemnation proceedings and to receive any Award made to such party in any such proceeding or as the result of negotiations with the agency or party exercising such right of expropriation, condemnation or eminent domain, subject, however, to the obligation of the respective parties to use and apply their respective Awards in the manner and for the purposes hereinabove provided. Lessor and Lessee further agree that neither will, without the other's written approval and consent, compromise or settle its claim or claims for damages, compensation or other monies to which it may be entitled by reason of such expropriation or condemnation proceedings.

For the purpose of this section, the terms "Award of both parties hereto", "Lessor's Gross Award", "Lessee's Gross Award", "Lessor's Net Award", and "Lessee's Net Award" shall have the meanings and are defined as follows:

The term "Award of both parties hereto" shall mean and refer to the total of the amounts of both the Lessor's Gross Award and the Lessee's Gross Award.

The term "Lessor's Gross Award" shall mean and refer to the amount awarded to or received by the Lessor as damages, compensation, or otherwise, by reason of the taking of the project or any part thereof as a result of or in anticipation of the exercise of the right of expropriation, condemnation or eminent domain.

The term "Lessor's Net Award" shall mean and refer to the amount remaining of Lessor's Gross Award, after deducting therefrom the costs and expenses, including, without limiting the generality thereof, reasonable attorneys' fees, expended or incurred by Lessor in and about or in anticipation of proceedings for expropriation or condemnation of the project or any part thereof.

The term "Lessee's Gross Award" shall mean and refer to the amount awarded to or received by the Lessee as damages, compensation or otherwise by reason of the taking of Lessee's leasehold interest or any part thereof, or the taking of any property installed or furnished by the Lessee pursuant to the provisions hereof which is the Lessee's own property and does not constitute part of the Project, as a result of or in anticipation of the exercise of the right of expropriation, condemnation, or eminent domain. 
The term "Lessee's Net Award" shall mean and refer to the amount remaining of the Lessee's Gross Award after deducting therefrom the costs and expenses, including, without limiting the generality thereof, reasonable attorneys' fees, expended or incurred by Lessee in and about or in anticipation of proceedings for expropriation or condemnation of the project or any part thereof.

SECTION 22. Quiet Enjoyment and Peaceable Possession.

The Lessor and the Lessee mutually covenant and agree that the Lessee, by keeping and performing the covenants and agreements herein contained to be kept and performed by it, shall at all times during the term of this Lease have the right to peaceably and quietly possess and enjoy the project, without suit, trouble or hindrance from the Lessor.

SECTION 23. Surrender of Project.

The Lessee covenants and agrees that, upon the termination of this Lease, it shall surrender to the Lessor the Project, together with any improvements thereon and thereto, in good order and condition, reasonable wear and tear excepted, and in a state of repair that is consistent with prudent use and conscientious maintenance thereof. Upon expiration of the Lease Term as provided in Section 8, Lessee may remove any fixture installed by it for its own use and for the purpose of promoting its business; provided further, however, that the Lessee shall repair all damages to the premises caused by or resulting from the removal of such fixtures.

SECTION 24. Subleasing by the Lessee.

Neither this Lease nor any interest of the Lessee therein shall, at any time be mortgaged or hypothecated by the lessee by voluntary act or by operation of law or otherwise.

The Lessee shall not, without the prior written consent of the Lessor, affect, pledge, assign, transfer or sublease to any person or corporation public or private, all or any portion of the Project.

SECTION 25. Assignment of Lease Payments by Lessor.

It is expressly understood and agreed by the parties hereto that the Lessor will pledge and assign this Lease, its rights hereunder and the rentals and other payments payable under section 9 hereof to secure the payment of the principal of and interest on the Bonds in the manner provided in the Bond Indenture. Upon the issuance and delivery of any of the Bonds the Lessor covenants and agrees to use and apply such rentals and other payments to pay the principal of and interest on the Bonds in the manner prescribed by the Bond Indenture. 


\section{SECTION 26. Right of Lessor to Perform Lessee's Obligations.}

If the Lessee shall fail to keep or perform, or shall fail to cause to be kept and performed any of its obligations as provided in the Lease in respect of: (a) maintenance of insurance; (b) payment of taxes, assessments, public charges or other impositions; (c) repairs and maintenance; (d) replacement, substitution or installation of equipment, furnishings, machinery or apparatus; (e) compliance with legal or insurance requirements; (f) keeping the Project free of liens; or ( $g$ ) the making of any other payment required by or the performance of any other obligation imposed upon it hereunder, then the Lessor, upon the continuance of such failure and without waiving or releasing Lessee from any obligation, as an additional but not exclusive remedy, may (but shall not be obligated to do so) take out the required insurance and pay the premiums thereon, make any of the aforesaid payments or perform any other aforesaid obligations; such amounts expended by Lessor shall be payable to Lessee on demand and shall bear per annum from date of demand.

SECTION 27. Defaults by Lessee; Remedies on Default and Waivers by Lessee.

If during this Lease, (i) the Lessee shall fail to pay when due and owing any rentals required by section 9 hereof and such failure shall continue for ten (10) days, or (ii) the Lessee shall fail to pay when due and owing any installment required by section 9 hereof and such failure shall continue for thirty (30) days; or (iii) the Lessee shall fail to observe or perform any other of the Lessee's covenants, agreements or obligations hereunder and such failure shall not be cured within thirty (30) days, or such additional time as is reasonably required to correct any such failure, after the Lessor shall have given to the Lessee written notice specifying wherein the Lessee has failed to observe or perform any such covenant, agreement or obligation; or (iv) if the Lessee's interest in this Lease or any part thereof be mortgaged, hypothecated, affected, pledged, assigned or transferred either voluntarily or by operation of law contrary to the provisions of Section 24 hereof; or (v) if the Lessee shall file any petition or institute any proceeding under the Bankruptcy Act, either as such Act now exists or under any amendment thereof which may hereafter be enacted, or under any act or acts, state or federal, dealing with or relating to the subject or subjects of bankruptcy or insolvency, or under any amendment of such act or acts, either as a bankrupt, or as an insolvent, or as a debtor, or in any similar capacity, wherein or whereby the Lessee asks or seeks or prays to be adjudicated a bankrupt, or is to be discharged from all or any of the Lessee's debts or obligaticns, or offers to the Lessee's creditors to effect a composition of extension of time to pay the Lessee's debts or asks, seeks or prays for a reorganization or to effect a plan or reorganization, or for a readjustment of the Lessee's debts, or for any other similar relief, or if any such petition or any such proceedings of the same or similar kind or character be filed or be instituted or taken against the Lessee, or if a receiver of the business or of the property or assets of the Lessee shall be appointed 
by any court, except a receiver appointed at the instance or request of the Lessor, of if the Lessee shall make a general any assignment for the benefit of the Lessee's creditors, or (vi) if the Lessee shall abandon or vacate the Project; then in any such event the Lessee shall be in default hereunder.

If the Lessee shall be in default hereunder as a result of the occurrence of one of the events indicated above in this Section, the Lessor may take any one or more of the following steps:

(a) The Lessor may re-enter and take possession of the Project without terminating this Lease, and sublease the Project for the account of the Lessee, holding the Lessee liable for the difference in the rent and other amounts payable by such sublessee in such subleasing and the rents and other amounts payable by the Lessee hereunder.

(b) The Lessor may terminate the Lease Term and exclude the Lessee from possession of the project and may lease the Project to another for the account of the Lessee, holding the Lessee liable for all rent and other payments due up to the effective date of such leasing and for the excess, if any, of the rent and other amounts payable by the Lessee under this Lease had the Lease Term not been terminated over the rents and other amounts which are payable by such new lessee under such new lease.

(c) The Lessor, may take whatever action at law or in equity may appear necessary or desirable to collect rents due, or to become due, or to enforce performance and observance of any obligation, agreement or covenant of the Lessee under this Lease.

SECTION 28. No Remedy Exclusive.

No remedy herein conferred upon or reserved to the Lessor is intended to be exclusive of any other available remedy, but each and every such remedy shall be cumulative and shall be in addition to every other remedy given under this Lease or now or hereafter existing at law or in equity or by statute. No delay or omission to exercise any right or power accruing upon any default shall impair any such right or power or shall be construed to be a waiver thereof, but any such right and power may be exercised from time to time and as often as may be deemed expedient.

SECTION 29. Breach by Lessor.

The Lessor shall in no event be in default in the performance of any of its obligations hereunder unless and until the Lessor shall have failed to perform such obligations within thirty (30) days, or such additional time as is reasonably required to correct any such default, after notice by the Lessee to the Lessor properly specifying wherein the Lessor has failed to perform any such obligation; provided, however, that so long as any Bonds are 
outstanding, the Lessee shall not be entitled to terminate the Lease or abate or reduce the rentals payable hereunder, but shall have and possess all other remedies provided by law.

SECTION 30. No Additional waiver Implied by one Waiver.

In the event any agreement contained in this Lease should be breached by either party and thereafter waived by the other party, such waiver shall be limited to the particular breach so waived and shall not be deemed to waive any other breach hereunder.

SECTION 31. The Lessor Not Liable in Certain Cases; Indemnification.

The Lessee shall indemnify and hold the Lessor, its board members, officers, agents and employees, harmless from, and defend them against, any and all liabilities, fines, suits, claims, demands, damages, liens, actions and judgments, and costs, counsel fees and expenses of any kind or nature whatsoever due to or arising out of (a) any breach, violation or non-performance of any covenant, condition or agreement in this Lease set forth and contained, on the part of the Lessee to be fulfilled, kept, observed and performed; or (b) any damage to property occasioned by the Lessee's use and occupancy of the Project and the site or either of them. If the Lessor, its board members, officers, agents and employees, or any of them be made a party to any action or proceeding arising out of any of the events or happenings contemplated by the preceding sentence, they may be entitled to appear, defend or otherwise take part at their election and by counsel of their own choosing, provided such action by them does not limit or make void any liability of any insurer of the Lessor or the Lessee hereunder in respect of the claim or matter in question. The Lessee's liability under this section shall be reduced by the net proceeds actually collected from any insurance carried for the Lessor's benefit on the risk in question.

\section{SECTION 32. Law Governing.}

This Lease shall be governed exclusively by the provisions hereof and by the laws of the state of Louisiana as the same from time to time exist, subject to the waivers and exclusions herein contained.

SECTION 33. Sole Agreement; Modifications of Lease.

This Lease (including the Exhibits hereto), and the Bond Indenture express the entire understanding and all agreements of the Lessor and of the Lessee with or pertaining to each other with respect to the project and the Site. This Lease may be amended or supplemented only by a written agreement signed by the Lessor and Lessee, but no amendment or supplement hereof may decrease the amount of the rentals or other payments prescribed herein. This Lease and any such amendments or 
supplements hereto shall constitute a contract between the Lessor and the Lessee in accordance with the terms and provisions hereof and thereof.

\section{SECTION 34. Validity.}

If any one or more of the terms, provisions, promises, covenants or conditions of this Lease shall to any extent be adjudged invalid, unenforceable, void or voidable for any reason whatsoever by a court of competent jurisdiction, each and all of the remaining terms, provisions, promises, covenants and conditions of the lease shall not be affected thereby and shall be valid and enforceable to the fullest extent permitted by law.

\section{SECTION 35. Notices.}

All notices, statements, demands, requests, consents, approvals, authorizations, offers, agreements, appointments or designations hereunder by the Lessor and Lessee to one another and each other shall be in writing and shall be sufficiently given and served upon the other, if sent by United States registered mail, return receipt requested, postage prepaid and addressed as follows:

If sent to the Lessee, the same shall be addressed as follows: New Orleans Public Service Inc., 317 Baronne street, New Orleans, Louisiana 70112, or at such other place as the Lessee may from time to time designate by written notice to the Lessor.

If sent to the Lessor, the same shall be addressed as follows: Chairman, Board of Trustees, Health Education Authority of Louisiana, State office Building, New Orleans, Louisiana 70112, or at such other place as the Lessor may from time to time designate by written notice to the Lessee. 
SECTION 36. Descriptive Headings.

The descriptive headings of the sections of this Lease are inserted for convenience of reference only and do not constitute a part of this Lease.

WITNESSES :

HEALTH EDUCATION AUTHORITY OF
LOUISIANA

By :

Title:

Chairman, Board of Trustees

By :

Title: 


\section{2.b.2 NOPSI UPDATED RATE SCHEDULE}

A copy of the current rate schedule prepared by NOPSI for the ICES users is included in this Section. This rate schedule is up to date and is based on data developed during the Phase II study.

Copies of correspondence from HEAL institutions expressing continuity of interest in the ICES program are included in the Appendix. 
NEW ORLEANS PUI IC SERVICE INC,

STEAM SERVICE SCHEDULE SS-1

(Based on Phase II Data)

APPLICATION OF SCHEDULE.

This schedule is applicable to the steati requircments of those institutions which are part of the Healti Education Authority of Louisiana (Heal) Complex.

NET MONTHLY BILL

The monthly bill per customer shall be the sum of the folloring charges:

(a) Demand Charge:

$\$ 1,005.00$ per thousand pounds of Billing Demand

(b) Cominodity Charges

1. Charge for Operating Expenses

$\$ 0.803$ per thousand pounds of steam furnished during the month

2. Charge for Fuel Expenses

$\$ 3.262$ per thousand pounds of steam furnished during the month

(c) Management Fee Charges

1. Fixed Charge

$\$ 100.00$ per thousand pounds of Billing Demand

2. Variable Charge

Eighteen (18) percent of the sum of the following:

a. Charges under (b) 1 . less cost of purchased

elcctrical energy

b. Charges under (f) 1. less cost of purchassed

electrical energy

(d) Credit for sale of Electrical Energy

$\$ 0: 772$ per thousand pounds of stean furnished during the month

(e) Demand Charse Adjustment.

Plus or minus the product of the Customer's Billing Demand for the month multiplied by the amount that the average actual demand cost per thousand pounds of $13 j .11 \mathrm{ing}$ Demand for all customers served unier this schcrule during the month is more or less than $\$ 1,005.00$.

(f) Commodity charge Adjustments

1. Operating Expenses

plus or minus the product of the thousands of pounds of 
steam used by the Customer during the month multiplied by the amount that the average actual operating expenses per thousand pounds of steam delivered to all customers served under this schedule during the month is more or less than $\$ 0.803$.

\section{Fuel Expenses}

Plus or minus the product of the thousands of pounds of steam used by the Customer during the month mutiplied by the amount that the average actual fuel expenses per thousand pounds of steam delivered to all customers served under this schedule during the month is more or less than $\$ 3.262$.

(g) Management Fee Charges Adjustment

Plus or minus the product of the Customer's Billing Demand for the month multiplied by the amount that the actual Fixed Charge cost per thousand pounds of Billing Demand for al.1 customers served under this schedule during the month is more or less than $\$ 100.00$.

(h) Credit for Sale of Electrical Energy Adjustment Plus or minus the product of the thousands of pounds of steam used by the Customer during the month multiplied by the amount that the payment for electrical energy delivered to NOPSI System form the Integrated Community Energy System. (ICES) during the month, per thousand pounds of steam delivered to all customers served under this schedule during the month is more or less than $\$ 0.772$.

(i) Tax Adjustment

Plus any taxes that Company may be required to pay to any governmental authority not collected in (b) above. The term "taxes" as used herein shall not include ad valorem, income, excess profits, corporation franchise, or other taxes which can be apportioned only on the basis of estimates.

\section{DEMAND CHARGE}

The purpose of the Demand Charge is to recover monthly costs of Plant. Financing and the Plant Reserve Fund and is based on Customer's Billing Demand.

\section{BILLING DEMAND}

The Billing Demand each month shall be the Customer's highest hourly demand occuring during the twelve month period ending with the current month.

\section{PAYMENT}

The net monthly bill calculated in accordance with the above rate will be increased five percent if payment is not made on or before the due date shown on the bill, which shall not be less than fifteen days after it is rendered.

\section{SERVICE PERIOD}

This schedule applies to service for a period and under the conditions as provided for in the lease agreement, Title number and Heal dated 
START-UP AND PARTIAL ANNUAL PERIONS

Beginning with initial service hercunder or following any major change in customer's load conditions, and until scrvice has been uced thereafter for twelve months, values of Billing Demand for computing the Demand Charge and Commodity Amount for computing the Operating Expense Charge may be estimated to produce equitable billing for service during such periods.

NOTE: These rates are subject to change pending future revisions in rate design data. 


\section{CHILLED WATER SERVICE SCHEDULE CWS-1}

\section{(Based on Phase II Data)}

\section{APPLICATION OF SCHEDULE}

This schedule is applicable to the chilled water requirements of those institutions which are part of the Health Education Authority of Louisiana (Heal) Complex.

\section{NET MONTHLY BILL}

The monthly bill per customer shall be the sum of the following charges:

(a) Demand Charge

$\$ 26.50$ per ton of Billing Demand

(b) Commodity Charges

1. Charge for Operating Expenses $\$ 0.0228$ per ton hour of refrigeration furnished during: the month

2. Charge for Fuel Expenses $\$ 0.0354$ per ton hour of refrigeration furnished during the month

(c) Management Fce Charges

1. Fixed Charge $\$ 2.64$ per ton of Billing lemand

2. Variable Charge

Eighteen (18) percent of the sum of the following:

a. Charges under (b) 1. less cost of purchased electrical energy.

b. Charges under ( $f$ ) 1 . less cost of purchased electrical energy.

(d) Credit for Sale of Electrical Energy $\$ 0.0084$ per ton hour of refrigeration furnished during the month

(e) Demand Charge Adjustment

Plus or minus the product of the Customer's Billing Demand for the month multiplied by the amount that the average actual demand cost per ton of Billing Demand for all customers served under this schedule during the month is more or less than $\$ 26.50$.

(f) Commodity Charge Adjustments

1. Operating Expenses

Plus or minus the product of the ton hours of refrigeration used by the Customer during the month multiplied by the 
amount that the average actual operating expenses per ton hour of refrigeration delivered to all customers served under this schedule during the month is more or less than $\$ 0.0228$.

\section{Fuel Expenses}

Plus or minus the product of the ton hours of refrigeration used by the Customer during the month multiplied by the amount that the average actual fuel expenses per ton hour of refrigeration delivered to all customers served under this schedule during the month is more or less than $\$ 0.0354$.

(g) Management Fee Charges Adjustment

Plus or minus the product of the Customer's Billing Demand for the month multiplied by the amount that the actual Fixed Charge cost per ton of Billing Demand for all customers served under this schedule during the month is more or less than $\$ 2.64$.

(h) Credit for Sale of Electrical Energy Adjustment Plus or minus the product of the ton hours of refrigeration used by the Customer during the month multiplied by the amount that the payment for electrical energy delivered to NOSPI System from the Integrated Community Energy System (ICES) during the month, per ton hour of refrigeration delivered to all customers served under this schedule during the month i:: more or less than $\$ 0.0084$.

(i) Tax Adjustment

Plus any taxes that Company may be required to pay to any governmental authority not collected in (b) above. The term "taxes" as used herein shall not include ad valorem, income, excess profits, corporation franchise, or other taxes which can be apportioned only on the basis of estimates.

\section{DEMAND CHARGE}

The purpose of the Demand Charge is to recover monthly costs of Plant Financing and the Plant Reserve Fund and is based on Customer's Billing Demand.

\section{BILL ING DEMAND}

The Billing Demand each month shall be the Customer's highest hourly demand occuring during the twelve month period ending with the current month.

\section{PAYMENT}

The net monthly bill calculated in accordance with the above rate will be increased five percent if payment is not made on or before the due date shown on the bill, which shall not be less than fifteen days after it is rendered.

\section{SERVICE PERIOD}

This schedule applies to service for a period and under the conditions as provided for in the lease agreement, Title number and Heal dated

, between NOPSI 
START-UP AND PARTIAL ANNUAI PERIODS

Beginning with initial service hereunder or following any major change in Customer's load conditions, and until service has been used thereafter for twelve months, values of Billing Demand for computing the Demand Charge arid Commodity Amount for computing the Operating Expense Charge may be estimated to produce equitable billing for service during such periods:

NOTE: These rates are subject to change ponding future revisions in rate design data. 
2.b.3 NOPSI LONG-TERM ENERGY SUPPLY CONTRACTS WITH INSTITUTIONS

A draft of a proposed service agreement between NOPSI and the HEAL institutions is included in this Section. 
Draft of Proposed Service Agreements Between New Orleans Public Service Inc. and H.E.A.L. Institutions

AGREEMENT, entered into on 19 between New Orleans Public Service Inc., a Louisiana corporation with its principal office at 317 Baronne Street, New Orleans, Louisiana (herein referred to as "Company"), and represented by , its

authorized to enter this Agreement, and duly

(herein referred to as "Customer"), and represented by , its authorized to enter into this Agreement.

WHEREAS, the Health Education Authority of Louisiana ("HEAL") will construct and own a thermal plant for the production of steail and chilled water, the primary purpose of which will be to serve the needs of the institutions located in the Louisiana Medical Complex in New Orleans, and

WHEREAS, the Company will operate this plant which will be leased from HEAL, and absorb all the electricity produced by the plant into the Company's electrical system, except that electricity required to operate the thermal plant, and

WHEREAS, this project is being undertaken by HEAL under contract with the Department of Energy as a demonstration of this type of plant, and

WHEREAS, the Customer has requested that Company provide such service, and

WHEREAS, the Customer is authorized to enter into this Agreement by virtue of

NOW THEREFORE, for and in consideration of the mutual benefits which shall accrue to the company and the customer, it is agreed that:

ARTICLE 1: DEFINITIONS

These terms shall be defined as follows: 
(a) Customer's premises: That property on which the served facility is located, be it owned, leased or otherwise held by the customer, starting at its boundary with adjoining property not held by the customer.

(b) Company Equipment: All machinery, piping, meters and other miscellaneous equipment owned, leased or otherwise held by the company used in connection with the operation or maintenance of this project.

(c) HEAL Equipment: All machinery, piping or other miscellaneous equipment owned, leased or otherwise held by HEAL used in connection with this project.

(d) Department of Energy Equipment: All machinery, pipjing or other miscellaneous equipment owned, leased or otherwise held by the Department of Energy used in connection with this project.

(e) Contractor or Subcontractor Equipment: All machinery, piping or other miscellaneous equipment owned, leased or otherwise held by contractors or subcontractors of the Company, HEAL or the Department of Energy used in connection with this project.

(f) Plant: Those parts of the Integrated Community Energy System (ICES), specifically excluding customer owned distribution facilities, which are used in the production of steam, chilled water and electricity.

(g) Demand Charge: That portion of the rate for service based cin actual or estimated maximum hourly usage of the customer.

(h) Billing Demand: The Customer's highest hourly demand cocurring during the twelve month period ending with the current month.

(i) Commodity Amount: The quantity of steam or chilled water used by the customer per month.

\section{ARTICLE 2: PREMISES SERVED: QUANTITY}

The Customer agrees that the Company shall make the necessary service connections and supply steam and chilled water to customer's premises at

Except as otherwise provided, the company shall supply and the Customer shall take from the company during the term of this Agreement all the steam and chilled water that shall be required on the above designated premises. 


\section{ARTICLE 3: TERM}

The term of this Agreement shall be $30 *$ years and $60 *$ days commencing with the first day of availability of steam or chilled water for delivery to the Customer's point of delivery.

\section{\begin{tabular}{ll} 
ARTICLE 4: INITIAL DELIVERY OF STEAM OR CHILLED WATER FOR & TESTING \\
\hline
\end{tabular}}

The Company recognizes that small amounts of steam and chilled water will be required for testing purposes before the commencement of regular service. Thus, notwithstanding any other provisions of this Agreement, the furnishing of such limited amounts of service shall be handled as follows:

(a) Charges for steam and chilled water furnished during the testing period will be derived from costs and allocated to the institutions on an equitable basis as determined by company and will be included in the first monthly bill after regular service commences.

(b) The provisions of this Article 4 are applicable only to steam service for testing which service is rendered within 60 days of the day on which the company first stands ready to deliver steam at the outset of this Agreement. The provisions are applicable only to chilled water service for testing which service is rendered within 60 days of the day on which the: Company first stands ready to deliver chilled water at the outset of this Agreement. Thereafter, regardless of the amount of steam or chilled water taken and even in the event none is taken, the customer shall be considered as being on regular service and shall be subject to all other provisions of this Agreement. Should regular service. (defined as service for purposes other than testing) commence before the 60 day periods elapse, this Article 4 shall cease to be effective when regular service commences.

(c) The other provisions of this Agreement are applicable during these initial periods except as they conflict directly with the provisions of this Article 4.

\section{ARTICLE 5: NOTICE OF CHANGE IN REQUIREMENTS}

The Customer shall give the Company at least 24 months advance notice in writing of any changes in buildings or operations which would materially increase or decrease the connected steam or chilled water load or capacity requirements of the Customer's facilities.

\footnotetext{
*Proposal only - subject to change at later date.
} 
(a) Steam shall be delivered to the customer at approximately 160* psig (approximately $1100 \mathrm{kPag}$ ) at saturated conditions (approximately $370^{\star}$ degrees Fahrenheit (approximately $187^{*}$ degrees Celsius)). All condensate shall be returred to the Company except that amount which cannot be conserved.

(b) Chilled water shall be delivered to the customer at approximately 50* psig (approximately $345 \mathrm{kPag*}$ ) and at approximately 40* degrees Fahrenheit (approximately 4.4* degrees Celsius). All such water shall be returned to the company approximately 15* degrees Fahrenheit (approximately 9.4* degrees Celsius) warmer than when delivered.

ARTICLE 7: POINTS OF DELIVERY AND REDELIVERY

The points of delivery and redelivery shall be where the steam and chilled water service pipes cross the boundaries of the Customer's premises entering and leaving such permises.

ARTICLE 8: CUSTOMER DISTRIBUTION EQUIPMENT

The Customer shall provide and install as necessary all piping and distribution equipment to be used on its premises except meters and like equipment. The installation or use of any such piping or equipment shall be subject to prior review by the company for compatability with company equipment and piping. Approval in no way implies any warranty of the adequacy, safety or other characteristic of the Customer's piping or equipment. The Customer shall be responsible for the proper maintenance of such equipment.

\section{ARTICLE 9: METERING}

The Company is hereby authorized to install, operate and maintain on the customer's premises a meter, meters or other such equipment of suitable capacity and design to measure the quantities of steam and chilled water provided under this Agreement. The location(s) and necessary protection for such equipment shall be provided by the customer at its expense. The location(s) shall be satisfactory to the company. The Company shall have free access to this equipment at all reasonable times. The customer is not in any way to attempt to adjust or otherwise tamper with the meter(s) or like equipment.

ARTICLE 10: DEPARTMENT OF ENERGY RESEARCH

The Customer shall permit the entry of Department of Energy personnel, its agents, contractors and subcontractors at all

*Figures are estimated only - estimates are subject to change. 
times for the purpose of conducting, testing and research in connection with this project. The customer shall permit the installation of any equipment which may be necessary for the testing and research so long as such installation does not interfere with the operation of Company or HEAL equipment. Upon request, the customer shall give access at all reasonable times to non-confidential records to those authorized to conduct the testing and research.

\section{ARTICLE 11: OWNERSHIP OF EQUIPMENT}

All equipment to be installed or placed on the Customer's premises which is owned by the Company, HEAL, the Department of Energy or their contractors and subcontractors or lessor of any of these parties shall remain the property of each after installation or placement unless otherwise provided. It shall be beaceably yielded upon request on discontinuance of service.

\section{ARTICLE 12: INDEMNITY}

The Customer shall indemnify and hold harmless the Company, HEAL, the Department of Energy, their agents, servants, employees and those of their contractors and subcontractors from all liability, claims, actions, damages, loss, costs and expenses (including attorney's fees) arising from damage to property (including that of the indemnitees) or injury or death of any person (including employees and agents of the indemnitees) occurring in the performance of this Agreement and use of the services herein contracted for when such is caused by any act, omission, or negligence of the customer, its agents, employees, servants or persons on its premises by license or invitation. The Customer shall indemnify and hold harmless the above indemnitees from all liability, claims, actions; damages, loss, costs and expenses (including attorney's fees) arising from damage to property (as defined above) or injury or death of any person (as defined above) regardless of fault therefor or lack of any fault, which is attributable to the presence, circulation or escape of steam or chilled water on the customers premises except that no party shall be indemnified or held harmless from the consequences of its own negligence. Nothing herein shall be interpreted to limit recourse to remedies otherwise available to the indemnitees. The customer shall assume the defense of any actions or claims brought against the above indemnitees at no expense to such indemnitees when the action or claim is covered by this Article.

\section{ARTICLE 13: RESALE, SHARING AND REMETERING PROHIBITED}

The Customer shall not resell, share, remeter or otherwise furnish steam or chilled water to others except that the customer may furnish such service to tenants on its premises if no specific charge is made therefor. 


\section{ARTICLE 14: USE OF STEAM FOR GENERATION OF ELECTRICITY PROHIBITED}

No steam furnished to the customer by the Company shall be used for the generation of electricity.

\section{ARTICLE 15: OTHER STEAM OR CHILLED WATER SERVICE}

(a) The customer shall not use any steam or chilled water service on its premises, other than that supplied by the company, without the written consent of the Company. Regardless of consent, the customer shall be responsible for any damage arising from the use of such other service. "Other service" shall include the production of steam or chilled water by Customer itself.

(b) In emergency situations oral consent by the Company, to be confirmed later in writing, will suffice.

(c) If the emergency is of a nature rendering contact with appropriate company officials impossible after the eyercisf: of due diligence to make contact and persons or property would be immediately imperiled by lapse or shortage of service the use of other service will be permitted without express consent; however, the customer shall remain responsibłe for any damase arising from the use thereof. Permission for the use of such other service under this section (c) shall remain effective only for so long as the emergency persists. The customer shall give the Company notice of the emergency use of other service as soor as feasible in light of the emergency conditions.

(d) Express or implied consent does not waive the reciuirements of Article 18 below.

ARTICLE 16: ADDITION OF WATER OR CHEMICALS TO SYSTEM PROHIBITED

The customer shall not add water or chemicals of any kind to the sieam or chilled water systems.

ARTICLE 17: FAILURE, SHORTAGE OR INTERRUPTION OF SERVICE

(i) The Company shall not be responsible for any failure, shortige or interruption of service or the consequences thereof when such is due to Acts of God, strikes, lockouts or other industrial disturbances; acts of public enemies; riot; war; blockades; insurrections; epidemics; environmental emergencies; fires: arrests; restraints of rulers or people or other governmental action; explosions; breakage or accident to machinery or pipes; necessary repairs or alterations to machinery or pipes; sidde:n partial or entire failure of machinery; freezing of machinery or pipes; emergencies wherein danger to persons or property make shut off or curtailment of service imperative; irability to obtain fuels or materials at a reasonable cost after due diligence or to ship same at reasonable cost; materially increased demand 
in the absence of 24 months notice; or any other cause, whether or not enumerated, which is not within the control of the company and which the Company cannot overcome by the exexcise of due diligence.

(b) The Customer shall remain obligated to take whatever steam or chilled water is made available to it by the company during shortage or curtailment of service regardless of the cause of such shortage or curtailment.

(c) The Customer's attention is specifically directed to Article 18, below, which shall remain in effect during any. failure, shortage, curtailment or interruption of service regardless of the cause of such failure, shortage, curtailment or interruption.

(d) The Customer's attention is also specifically directed to Article 15, above, on use of other steam or chilled water service.

\section{ARTICLE 18: RATES $^{1}$}

(a) Charges for steam and chilled water service shall be made according to the following schedules:

$$
\frac{\text { NEW ORLEANS PUBLIC SERVICE INC. }}{\text { STEAM SERVICE SCHEDULE SS-I }}
$$

\section{NET MONTHLY BILL}

The monthly bill per customer shall be the sum of the following:

(a) Demand Charge

$$
\begin{aligned}
& \$ \text { per thousand pounds per } \\
& \text { hour of billing demand; }
\end{aligned}
$$

(b) Commodity Charges

1. Charge for Operating Expenses

$$
\begin{aligned}
& \text { per thousand } \\
& \text { pounds of steam firnished during } \\
& \text { the month; }
\end{aligned}
$$

2. Charge for Fuel Expenses

$$
\begin{aligned}
& \text { pounds of steam furnished during } \\
& \text { the month; and }
\end{aligned}
$$

\footnotetext{
${ }^{I}$ See proposed rate schedules immediately following this service Agreement.
} 


\section{Charge for Management Fee}

percent of the charges under 1 . and 2. above including their respective adjustments ;

(c). Credit for Sale of Electrical Enerçy $\$$ of steam furnished during the month;

(d) Demand Charge Adjustment

Plus or minus the product of the Customer's Billing Demand for the month multiplied by the amount that the average actual demand cost per thousand pounds of billing demand for all customers served under this schedule curing the month is more or less than item (a) "Demand Charge", above;

(e) Commodity Charge Adjustments

1. Operating Expenses

Plus or minus the product of the thousands of pounds of steam used by the: customer during the month multiplied by the amount that the average actual operating exrenses per thousand pcunds of steam de:livered to all customers served under this schedule during the month is more or less than item (b) 1, above; and

2. Fuel Expenses

Plus or minus the product of the thousands of pounds of steam used by the customer during the month multiplied by the amount that the average actual fuel expenses per thousand pounds of steam delivered to all customers served under this schedule during the month is more or less than item (b) 2 , above;

(f) Credit for Sale of Electrical Energy Adjustment Plus or minus the product of the thousands $\cdots$ of pounds of steam used by the customer during the month multiplied by the amount 
that the credit for surfilus electrical energy delivered to the company's electrical system from the Plant during the month, per thousand pcurds of steam delivered to all customers served linder this schedule during the month is more. or less than item (c), above; and

(g) Tax Adjustment

Plus any taxes that Company may be required to pay to any governmental authority not collected in (b) above. The term "taxes" as used herein shall not include ad valorem, income, excess profits, corporation franchise, or other taxes which can be apportioned only on the basis of estimates.

\section{START-UP AND PARTIAL ANNUAL PERIODS}

Beginning with initial service hereunder or following any major change in customer's load conditiors, and until service has been used thereafter for twelve months, values of Billing Demand for computing the Demand Charge and Commodity Amount for computing the operating Expense Charge may be estimated to produce equitable billing for service during such periods.

NEW ORLEANS PUBLIC SERVICF INC.

CHILLED WATER SERVICE SCHEDULE CW S-I

\section{NET MONTHLY BILI}

The monthly bill per customer shall be the sum of the following charges:

(a) Demand Charge $\$$ per ton of billing demand;

(b) Commodity Charges

1. Charge for Operating Expenses

$\$$ per ton hour of chilled water furnished during the month;

2. Charge for Fuel Expenses $\$$ per ton hour of chilled water furnished diring the month; arid

3. Charge for Management Fee percent of the charges inaer 1 . and 2. above including their respective adjustments; 
(c) Credit for Sale of Electrical Energy if per ton hour of chilled water furnished during the month;

(d) Demand Charge Adjustment

Plus or minus the product of the Customer's Billing Demand for the month multiplied by the amount that the average actual demand cost per ton of billing demand for all customers served under this schedule duxing the month is more or less than item (a)

"Demand Charge", abcive;

(e) Commodity Charge Adjustments

\section{Operating Expenses}

Plus or minus the product of the ton hours of chilled water used by the Customer during the month multiplied by the amount that the average actual operating expenses per ton hour of chilled water delivered to all customers served under this schedule during the month is more or less than item (a) 1 , above; and

2. Fuel Expenses

Plus or minus the prodict of the ton hours of chilled water used by the Customer during the month multiplied by the amount that the average actual fuel expenses per ton hour of chilled water delivered to all custoriers served under this schedule during the month is more or less than item (a) 2, above;

(f) Credit for Sale of Electrical Energy Adjustment

Plus or minus the product of the tor hours of chilled water used by the customer during the month multiplied by the amount that the credit for surplus electrical energy delivered to the Company's electrical system from the plant during the month, per ton hours of chilled: water delivered to all customers served under this schedule during the month is more or less than item (c), above;

(g) Tax Adjustment

Plus any taxes that Company may be required to 
pay to any governmental authority not collected in (b) above.

The term "taxes" as used herein shäll not include ad valorem, income, excess profits, corporation franchise, or other taxes which can be apportioned only on the baisis of estimates

\section{START-UP AND PARTIAL ANNUAL PERIODS}

Beginning with initial service hereunder or following any major change in customer's load conditions, and until service has been used thereafter for twelve months, values of Billing Demand for computing the Demand Charge and Commcdity Amount for computing the operating Expense Charge may be estimated to produce equitable billing for service during such periods.

(b) The Company may render a bill based on estimated usage when all or part of the steam or chilled water provided to the customer is not properly metered. When errors in registration or other malfunction of the metering system are discovered after bills for the period or periods in which the malfunction occurred are rendered, the billing for that period or periods shall be recalculated and the customer shall either receive a credit of: any amount due him on the bill for the month following the month of discovery of the malfunction or be charged for any amount which should have been billed to him which charge shall appear on the the bill for the month following the month of discovery of the error.

(c) The net monthly bill calculated in accordance with this Article will be increased by five (5) percent if payment is not made on or before the due date shown on the bill, which shall be not less than fifteen (15) days after it is rendered.

\section{ARTICLE 19: BILLING}

Bills shall be rendered monthly and shäll be payable at the Company's main office not later than fifteen (15) days after each bill is rendered. Any billing may include less than one month's charges or up to 2 months' charges when such is required to set a uniform billing date for all customers receiving service from the plant.

\section{ARTICLE 20: DISCONTINUANCE OF SERVICE}

The Company is hereby authorized to discontinue the supply of steam or chilled water and to remove its meters and othe:r property from the Customer's premises whenever the Customer shall:

(a) fail to pay any bill rendered by the company,

(b) fail to cure any default or breach of customer 
covenant or obligation hereunder within 30 days of written notice thereof,

(c) use the services in a manner which threatens substantial damage to any facilities of the company, or

(d) as necessary tc protect the company from fraud or. abuse, including meter tampering.

The exercise of this right shall be in addition to any and all other remedies otherwise available to the Company. Reconnection may be had upon cure of (a) through (d) abcive and upon payment of a reconnection charge based on the amount to be expended for labor, overheads and materials to make the reconnection. The Customer's attention, is specifically directed to Articles 15 and 18, above, which shall remain in effect during any discontinuance of service under this Article 20.

ARTICLE 2I: WAIVERS

No waiver by the Company or the Customer of any default of the other under this Agreement shall operate as a waiver of any future default whether of like or differeñt character.

ARTICLE 22: SUCCESSORS AND ASSIGNS; ASSIGNMENTS

All covenants, stipulations, terms, conditions and provisions of this Agreement shall extend to and be made binding upon the respective successors and assigns of the company and the customer and benefits and rights conferred hereir on third parties shall extend to their successors and assigns. Any conveyance, assignment or other agreement affecting this Agreement shall be made expressly subject to it. If this Agreement itself is assigned, the assignor shall cause the assignee to assume all of its provisions. This Agreement is noy transferrable to the customer except with written consent of the company, which shall have the right to review the documents effecting the assignment.

ARTICLE 23: LOUISIANA LAW APPLIES

This Agreement shall be governed by the laws of the State of Louisiana. 


\section{ARTICLE 24: ENTIRE AGREEMENT}

This document constitues the entire agreement between the parties and supersedes any prior agreements or understanding.

IN WITNESS WHEREOF, the parties hereto heve executed tris Agreement in multiple criginals in New Orleans, Louisiana.

WITNESS :

NEW ORLEANS PUESIC: SERVICE INC.

By

Tit.le

By

Title

[Final signature of this service agreement is contingent upon a satisfactory showing of economic benefit to (name of institution) and upon NOPSI's satisfaction with the arrangements made to finance the: project] 


\section{2.b.4 FINANCING PLAN, BOND ISSUE}

A financing plan and accompanying letter from Howard, Weil, Labouisse, Friedrichs, Incorporated, bond counsel for HEAL are included in this Section. This is an updated plan, based on data developed during preparation of the Phase II report.

A request for a ruling on the tax-exempt status of the proposed bond issue has been forwarded to the U.S. Internal Revenue Service and a copy of the letter requesting this ruling appears in the Appendix. 


\section{Howard, Weil, Labouisse, Friedrichs INCORPORATED \\ Investment Securities \\ 2II CARONDELET STREET \\ New OrLeans, La. 70130 \\ $504-588-2711$}

MEMBERS

NEW YORK STOCK EXCHANGE

AMERICAN STOCK EXCHANGE

CHICAGO BOARD OF TRADE

CHICAGO MERCANTILE EXCHANGE

CABLE

"HOWVEST"

March 7, 1978

Mr. Michael Abralms

Health Education Authority of Louisiana

Room 213, State Office Building

325 Loyola Avenue

New Orleans, Louisiana 70112

RE: HEAL - NOPSI

ICES Project

Dear Mike:

Please find enclosed a Working Draft for the above captioned project. You will note that the issue has risen by only $\$ 1 \frac{1}{2}$ million despite an increase in the estimated construction cost of the same amount. The reason is the reinvestment rate estimate has been raised to $6.5 \%$ because of the recent upturn in the cost of money and this allows us to earn in interest as much as we pay out during the construction period. While all these numbers clearly are estimates, I believe they are conservative and attainable in the near future.

As we have stated earlier, it is our professional opinion that subject to execution by the members of HEAL of a "take or pay" contract, an acceptable engineering feasibility study and approval of a bona resolution, an issue of approximately $\$ 45,000,000$ of tax-exempt revenue bonds can be marketed on reasonable terms. The undersigned is prepared to enter into an underwriting agreement with HEAL on a contingency basis.

Sincerely,

Mark A. Tessier

Vice President

Public Finance Department

MAT/al

Enclosure 
HEAL - ICES

WORKING DRAFT

Howard, Weil, Labouisse, Friedrichs Incorporated March 7,1978 


\section{HEAL - ICES}

$(\$ 000)$

\section{ASSUMPTIONS:}

A Rating

Term of Issue

30 Years

Net Interest Cost of the Bond Issue

$6.50 \%$

Interest Rate on Reinvestment of Construction Funds and Capitalized Interest

$6.50 \%$

Interest Rate on Reinvestment of Debt Service Reserve

6. $50 \%$

Length of Construction Period in Years

3

Construction Cost

$\$ 34,500$

FORMULATIONS:

Construction Cost Including Contingency and Land

$\$ 34,500$

plus Interest Capitalized during Construction Period

8,325

plus Debt Service Reserve Requirement

3,400

plus Bond Counsel's Fee

plus Cost of Printing

plus Cost of Feasibility Study

plus Other Issuing Expenses

plus Bond Discount

less Interest Earned on Investment of Construction Funds, Capitalized Interest and Debt Service Reserve 
[IERT SERUICE SCHEIULE

\section{PAYMENT FERION}

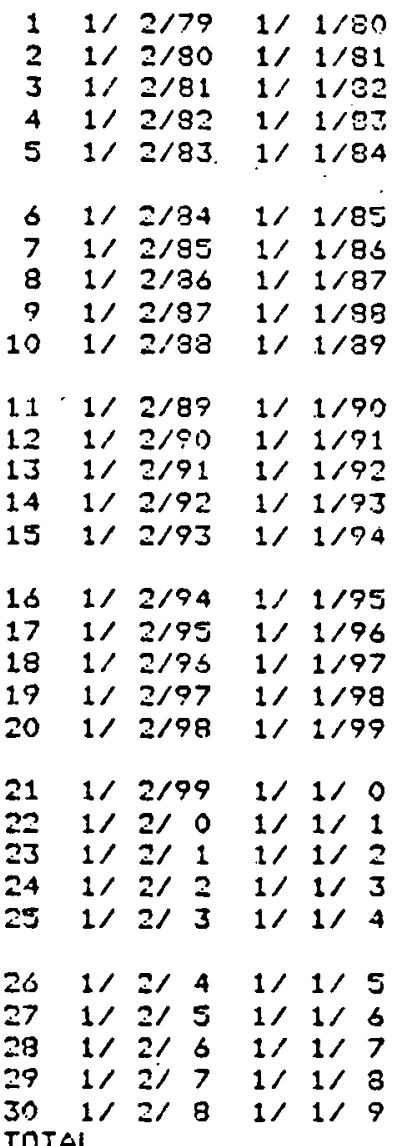

FFINCIF'AL

$\$ 620,000.00$

$\$ 600,000.00$

$\$ 700,000.00$

$\$ 750.000 .00$

$\$ 795,000.00$

$\$ 850,000.00$

$\$ 905,000.00$

$\$ 960,000.00$

$\$ 1,025,000.00$

$\$ 1,090,000.00$

$\$ 1,160,000.00$

$\$ 1,235,000.00$

$\$ 1,315,000,00$

$\$ 1,405,000.00$

$\$ 1,495,000.00$

$\$ 1,590,000.00$

$\$ 1.695,000.00$

$\$ 1,805,000,00$

$\$ 1,920,000.00$

$\$ 2,045,000.00$

$\$ 2.180,000.00$

$\$ 2,320,000.00$

$\$ 2,475,000.00$

$\$ 2.635 .000 .00$

$\$ 2,805,000.00$

$\$ 2,985,000.00$

$\$ 3,180,000.00$

$\$ 42,600,000.00$
INTEF:EST

$$
\begin{aligned}
& \$ 2,759,000.00 \\
& \$ 2,759,000.00 \\
& \$ 2,769,000.00 \\
& \$ 2,769,000.00 \\
& \$ 2,728,700.00 \\
& \$ 2,635,300.00 \\
& \$ 2,640,300.00 \\
& \$ 2,591,550.00 \\
& \$ 2,539,875.00 \\
& \$ 2,484,625.00
\end{aligned}
$$

$\$ 2,425,800.00$ $\$ 2,363,400.00$ $\$ 2,296,775.00$ $\$ 2.225,725.00$ $52,150,525.00$

$\$ 2.070,250.00$ $\$ 1,984.775 .00$ $31.893,450.00$

$\$ 1,796,275.00$

$\$ 1,692,925.00$

$\$ 1,562,750.00$

$\$ 1.465 .425 .100$

$\$ 1,340,625.00$

$\$ 1,207,700.00$

$\$ 1,066,000.00$

$\$ 915,200.00$

$\$ 754.325 .00$

$\$ 583,050.00$

$\$ 400,725.00$

$\$ 206,700.00$

$\$ 57,169,450.01)$
TDTAL

$\$ 2,769,000.00$ $\$ 2,769,000.00$ $\$ 2,759.000 .00$ $\$ 3.399 .000 .00$ $\$ 3,385,700.00$

$\$ 3,335,300.00$ $\$ 3,390,300.00$ $35,336.550 .00$ $\$ 3.389 .275 .00$ $\$ 3.339 .025 .00$

$\$ 5.335,390.00$ 33.338 .400 .00 $\$ 3.385,775,00$ $\$ 3,335.925 .00$ 5. $335,525.00$

$\$ 3,335,255.00$ $\$ 3.339 .775 .00$ $\$ 3,335,450.01)$ $53,336,275.00$ $\$ 3,387,925.00$

$\$ 3.337,750.00$ $\$ 3,335,425.00$ $\$ 3,395.625 .00$ $\$ 3,387,700.00$ $\$ 3,330,000.00$

$53,390,200.00$ $\$ 3,33 \%, 325.00$ $\$ 3,338.050 .00$ $\$ 3.355 .725 .00$ $\$ 3,736,700.00$ $\$ 99.709 .450 .00$ 


\section{2.b.5 PLANT SITE OPTION AGREEMENT}

A draft of the "Offer to Sell" prepared for the specific site selected for the ICES central energy plant is included in this section. 
STATE OF LOUISIANA

PARISH OF ORLEANS

DATE

OFFER TO SELL

I (we) the undersigned do hereby make an irrevocable exclusive offer to sell the following described property to the Health Education Authority of Louisiana under the following terms and conditions, to-wit:

1. TERM OF OFFER: This offer shall be effective from the date above stated and may be withdrawn at 11:59 p.m. on the Two Hundred and Fortieth (240) day after date thereof.

2. PROPERTY DESCRIPTION: A Certain lot or parcel of ground in the City of New Orleans, containing approximately 1.20 acres in the square designated as No. 365, bounded on the east by LaSalle Street, on the north by Perdido Street, and on the west by Freret Street, extending to the south to a boundary approximately 150. feet from Poydras Street.

3. PURCHASE PRICE: In the event that this offer is timely exercised by the offeree or his assigns in accordance with the terms and conditions of this agreement, then the purchase price for the property described above shall be the sum of

4. ACCEPTANCE OF OFFER: In the event that the Offeree or its assigns desire to exercise the offer herein granted, it shall notify Offeror in writing of its exercise of said offer by handing written notice to the offeror or mailing same to him at his mailing address no later than Two Hundred and Forty (240) days after the effective date of this agreement.

In the event that offeree or its assigns notify the offeror of its intention to exercise said offer to purchase the aforedescribed property in the manner herein set forth, the Offeror agrees within Thirty (30) days from receipt of said notice to execute a good and sufficient warranty deed prepared by counsel for offeree conveying the property to the said offeree free of all mortgages, liens, or other encumbrances and with full substitution and subrogation to all of Dfferor's rights and actions of warranty against all preceeding owners and vendors. The time and place for passing of title to the property herein offered shall be designated by offeree. 
5. REJECTION OF OFFER: The failure of the Offeree to timely and properly exercise the offer granted herein shall amount to the rejection of said offer.

6. RIGHT OF SPECIFIC PERFORMANCE: The Offeree, having properly and timely exercised said offer in the manner above shown, the offer and acceptance of Offeror's offer, as contained herein; and the acceptance thereof by offeree, shall ipso facto, then constitute a contract to sell and buy with respect to the property described hereinabove, and both parties shall have and receive all the rights and obligations imposed by law on parties to such an agreement, including the right of specific performance. The parties especially understand and agree that this offer shall be binding upon offeror and he may. not offer the above described property for sale to any other entity during the term of this offer.

7. WARRANTY OF TITLE: Offeror warrants that he can present a legal, valid and merchantable record title, free and clear of all liens, encumbrances, and mortgages of any nature or description; provided, however, that the said offeree shall have the right, at its option, to waive any defects to title.

8. ASSIGNMENT: Offeror hereby agrees that all rights acquired under this offer by offeree, may be transferred by offeree to any assignee or transferee of its choosing, and such transferee may exercise the aforesaid offer on the same terms and conditions as stated herein. Offeror specifically agrees that in the event of such a transfer by offeree, the transferee, or transferees, thereafter shall be substituted for the Offeree for all purposes of this agreement, and henceforth Offeree shall have no further liability. The transferee or transferees, shall furnish Offeror with a duly executed or certified copy of the transfer, accompanied by written notice of the address of the transferee, or transferees, for notice purposes.

9. PRORATION OF PROPERTY TAXES: The property taxes shall be prorated between the parties hereto as of the date of the passage of the act of sale and shall be paid by offeror at passage of the act of sale.

10. EFFECT OF ACCEPTING THE OFFER: If this offer is timely accepted by the Offeree or its assigns, in accordance with this agreement, then it shall ipso facto, be converted into a buy and sell agreement between the parties hereto and the right of specific performance will accrue to both parties. 
11. The word "Offeree" as used herein shall likewise apply to any transferee, or transferees, and all rights and obligations here granted. or imposed upon Offeree shall likewise apply to Offeree, transferee, or. transferees. This offer shall likewise be binding upon the heirs, and/ or assigns of the offeror.

12. PAYMENT: The purchase price for the property above described shall be the sum of

and shall be paid in cash at the time the act of sale is passed in the event that this offer is timely accepted by the offered.

WITNESSES:

OFFEROR

92 


\section{2.b.6. EASEMENT \& RIGHT-OF-WAY AGREEMENTS}

A draft of a "Servitude Agreement" for the thermal energy distribution systems with respect to presence on institutional private property is included. 


\section{SERVITUDE AGREEMENT}

THIS AGREEMENT between

(hereinafter referred to as "Owner") and Health Education Authority of Louisiana (hereinafter referred to as "HEAL"), herein represented by

Vernon D. Seifert, its Executive Director.

W I T N ES E TH:

WHEREAS,

WHEREAS, Owner has requested HEAL to make steam and chilled water available to Owner's property described hereinabove; and

WHEREAS, in order to provide steam and chilled water service it will be necessary for HEAL to install facilities on the above described property of Owner.

NOW, THEREFORE, for and in consideration of the convenience and benefits which shall accrue to. Owner from the installation of facilities on Owner's property, it is agreed that:

1. Owner hereby grants to HEAL, its successors or assigns, a servitude under, over, across and upon the following portion of the above described property, to-wit:

Which said portion of ground is shown as a shaded area on Drawing No. , dated which is attached hereto and made a part hereof.

Said servitude includes the right of ingress and egress at any and all times for the purpose of installing, operating and maintaining the facilities described below. HEAL shall also have the right to render service to other properties and customers from the distribution system installed within the servitude area.

2. HEAL, its successors or assigns, shall construct, operate and maintain the distribution system (which shall be and remain the property of HEAL) consisting of the necessary piping, devices and supports, and shall indemnify and hold Owner harmless for any damage, loss or injury caused by 
the negligence of HEAL, its successors or assigns, in the installation, operation and maintenance of said equipment, except that under no circumstances shall HEAL be responsible for any damage, loss or injury caused by acts of God, strikes, force majeure, riots and civil commotion, or acts of negligence of Owner, its successors or assigns, or their agents, employees or tenants.

3. Owner shall furnish the servitude area free and clear of any obstruction and shall not construct or permit the construction or placing of any obstruction which would interfere with the exercise of the rights herein granted, provided that Owner shall have the right to make use of the said area as long as said usage does not interfere with the rights herein granted to HEAL.

4. HEAL shall have the right to trim trees, bushes and other growth so as to provide proper clearance for its facilities in the said servitude area and shall have the right to remove from said area, at Owner's expense, any obstruction to the proper operation, inspection and maintenance of its facilities.

5. Owner, its successors or assigns, shall bear the cost of any relocation or modification of said facilities and equipment when such relocation or modification is brought about by the requirements of Owner, its successors or assigns.

IN WITNESS WHEREOF, the parties hereto have this , 19 , signed this agreement. day of

WITNESSES:

By

Title

HEALTH EDUCATION AUTHORITY OF LOUISIANA

By

Title 


\section{2.b.7 ZONING VARIANCE}

It is considered premature to effect a draft of Zoning Variances at this time. Later, when further progress is made in implementing the ICES Project, the City Planning Commission can be formally approached in regard to this matter.

The proposed location of the plant is in Square No. 365 , located within the area of the HEAL Complex. This square is rated LI, or Light Industrial; listed with in this category are many different classifications, some of which are not far in relation to ICES. Therefore, it is not unreasonable to consider that zoning requirements represent a fairly minor matter.

Several months ago representatives of HEAL and Kidde Consultants met with the Executive Director of the City Planning Commission. The project was discussed in detail with him, and, as a consequence, design location is based on locating the plant at a sufficient distance from Poydras Street to allow commercial establishments on Poydras in Square No. 365. This street is rapidly building up in prime importance in the City of New Orleans, since it has on it now, among other important buildings, the Superdome, the HyattRegency Hotel, the Amoco Building, I Shell Square, several important Federal buildings, and new Hilton Hotel.

We have complied with the Executive Director's wishes and foresee no problems with Zoning Variances. 


\section{2.b.8 LABOR RELATIONS PLAN}

NOPSI, the ICES operator, has prepared a statement relative to labor relations, as follows:

"New Orleans Public Service Inc. hereby gives notice that labor relations will be handled under its International Brotherhood of Electrical Workers (IBEW) Local 1700 Contract dated October 10, 1977, copies of which can be obtained from New Orleans Public Service Inc." 


\section{2.b.9 PREL IMINARY ENVIRONMENTAL ASSESSMENT}

Presented herein is the draft of the preliminary environmental assessment. This document has been distributed to. the different agencies who might be concerned. 


\title{
DRAFT
}

ENVIRONMENTAL IMPACT ASSESSMENT

DEVELOPMENT OF GRID-CONNECTED

INTEGRATED COMMUNITY ENERGY SYSTEM.

BY

HEALTH EDUCATION AUTHORITY OF LOUISIANA

NEW ORLEANS, LOUISIANA

AND

\section{U.S. DEPARTMENT OF ENERGY}

ADMINISTRATIVE ACTION

\author{
SUBMITTED PURSUANT TO SECTION 102 (2)(C), P.L. 91-190 \\ OCTOBER, 1978
}

NEW ORLEANS PUBLIC SERVICE INC.

KIDDE CONSULTANTS, INC.

Orr-Schelen-Mayeron \& Associates, Inc. 


\author{
DEVELOPMENT OF A GRID-CONNECTED \\ INTEGRATED COMMUNITY ENERGY SYSTEM! \\ HEALTH EDUCATION AUTHORITY OF LOUISIANA \\ NEW ORLEANS, LOUISIANA.
}

\section{(X) Draft}

Responsible Office:

1. Name of Action:
Heal th Education Authority of Louisiana Room 213 State Office Building 325 Loyola Avenue

New Orleans, Louisiana 70112 (504) $568-5836$

( $x$ ) Administrative ( ) Legislative

2. Description of the Action: The Health Education Authority of Louisiana (HEAL) proposes to build and operate an Integrated Community Energy System (ICES) to produce steam and chilled water for each of the HEAL member institutions and additionally to generate by-product electricity to be used as required by plant functions with the excess, if any, to be fed into the New Orleans Public Service Inc. (NOPSI) electrical grid. There are 26 buildings to be served among the five member institutions spread over a 43acre site in central New Orleans. The electricity supplied to the grid will be the maximum available after meeting plant thermal demands to give a higher ratio of energy output to energy input. This ICES should thereby provide a more efficient conversion of energy than the existing non-integrated systems. The project should also provide a reliable and economical source of energy for the HEAL complex over the life of this ICES. The ICES plant will be able to use any one of several fuels - natural gas, fuel oil, coal, or processed municipal solid waste. The ability to choose fuels based on availability and price will assure continued operation and economy (of fuel cost). The energy savings to HEAL are estimated to be in excess of $\$ 150,000,000$ over the period 1982 to 2000 . It is proposed that the project be part of a national program by the Department of Energy to demonstrate efficient use of fuel to produce thermal and electrical energy.

\section{Summary of Impacts:}

(a) Environmental Impacts: Construction of this ICES will mean additional employment for many construction workers. During operation of the ICES, some of the workers released from work in the existing dispersed steam and chilled water plants may be employable in the new plant. A plot of land in the HEAL complex that is currently under-utilized will be used for the site of this ICES plant. The integrated plant will lead to less fuel usage for the same amount of useful energy produced by the existing plants and will also provide favorable economy of scale in pollution control equipment as compared to the present dispersed plants were they forced to 
convert to other fuels.

(b) Adverse Environmental Impacts: The plant will be designed to minimize air, water and noise pollution sources during normal operations. In the event of an upset condition, however, there is the potential for temporary air or noise pollution and water pollution (of Lake Pontchartrain through the city storm drainage system). There will be a minor increase in truck traffic into and out of the ICES plant when firing with fuels other than natural gas. There will be visual impacts due to the above ground distribution lines, the plant with its cooling tower plumes and the exhaust gas stack.

4. Alternatives: The main alternative is to maintain the existing separated steam and chilled water plants. If these plants remain capable of firing only natural gas, the prospect of curtailed operations during natural gas shortages must be realized. A second alternative is that some of the existing plants could individually convert to multiple fuel usage; however, others could not, due to location and space limitations. This alternative would eliminate the visual impact of the ICES project since it would have potentially the same air, water and noise impacts, but would not have the favorable energy efficiency of the ICES project.

Another alternative would be a change to all electric production of the needed thermal energy; however, excessively high initial costs and estimated higher operational costs make this alternative not as desirable as the proposed action. Regarding the pipe distribution system, an alternative to the overhead system would be the construction of an underground tunnel in the street for the piping system. This too, would be far more expensive and would be very disruptive to traffic in a very critical emergency zone.

5. COMMENTS REQUESTED:

\section{FEDERAL}

Senator Russe11 B. Long, Washington, D.C.

Senator J. Bennett Johnston, Washington, D.C.

Representative Lindy Boggs, Washington, D. C.

Representative Robert Livingston, Washington, D. C.

Advisory Council on Historic Preservation, Washington, D. C.

Department of Commerce; Washington, D. C.

Community Services Administration, Dallas, Texas

U. S. Environmental Protection Agency (Regional Office), Dallas, Texas

U. S. Environmental Protection Agency, Washington, D. C.

Department of Health, Education, and Welfare, Public Health Service, Dallas, Texas

Water Resources Council, Washington, D. C. 
Louisiana Commission on Intergovernmental Relations, Baton Rouge, Louisiana

Governor's Council on Environmental Quality, Baton Rouge, Louisiana

Joint Legislative Commission on Environmental Quality,

Baton Rouge, Louisiana

Louisiana Air Control Commission, New Orleans, Louisiana

Louisiana Department of Natural Resources, Baton Rouge, Louisiana

Louisiana Department of Health and Human Resources, New Orleans, Louisiana

Louisiana State Planning Office, Baton Rouge, Louisiana

Louisiana. Public Service Commission, Baton Rouge, Louisiana

Louisiana Department of Public Works, Baton Rouge, Louisiana

Louisiana Wildlife and Fisheries Commission, Baton Rouge, Louisiana

LOCAL

Regional Planning Commission, New Orleans, Louisiana

Jefferson Parish Planning Department, Metairie, Louisiana

Mayor, City of New Orleans, New Orleans, Louisiana

New Orleans City Planning Commission, New Orleans, Louisiana

Westwego City Planning Commission, Westwego, Louisiana

Metropolitan Area Committee, New Orleans, Louisiana

Councit, City of New Orleans

\section{ENVIRONMENTAL}

Sierra Club, Delta Chapter, New Orleans, Louisiana

Ecology Center of Louisiana, Inc., New Orleans, Louisiana

League of Women Voters of Jefferson Parish, Marrero, Louisiana

American Lung Association of Louisiana, Inc., New Orleans, Louisiana American Cancer Society, New OrTeans, Louisiana

Cancer Association of Greater New. Orleans, New Orleans, Louisiana

American Heart Association - Louisiana, Inc., New Orleans, Louisiana

\section{OTHERS}

Chamber of Commerce of the New Orleans Area, New Orleans, Louisiana Bureau of Governmental Research

New Orleans Center for Housing and Environmental Law, New Orleans, Louisiana

Tulane Medical Center, New Orleans, Louisiana

Louisiana State University Medical Center, New Orleans, Louisiana

Charity Hospital of Louisiana at New Orleans, New Orleans, Louisiana

Veterans Administration Hospital, New Orleans, Louisiana

Eye, Ear, Nose and Throat Hospital, New Orleans, Louisiana

Fire Protection Bureau, City of New Orleans, La.

Middle South Utilities, Inc.

Health Systems Agency 
DRAFT

\author{
ENVIRONMENTAL ASSESSMENT \\ DEVELOPMENT OF GRID-CONNECTED \\ INTEGRATED COMMUNITY ENERGY SYSTEM \\ BY THE HEALTH EDUCATION AUTHORITY OF \\ LOUISIANA \\ NEW ORLEANS, LOU ISIANA
}

TABLE OF CONTENTS

PARAGRAPH

TITLE.

PAGE

SUMMARY

SECTION 1 -- PROJECT DESCRIPTION

105

1.01 General

1.02 Location of project area

$1.03^{\circ}$ Purpose, $\mathrm{pl}$ an, and status

1.04 Operation and maintenance

1.05 Authorization

SECTION 2 -. ENVIRONMENTAL SETTING WITHOUT. HEAL ICES PROJECT

108

2.01 General

2.02 Air Quality

2.03 Water Quality

2.04 Noise

2.05 Economic

2.06 Future environmental conditions of the area without the HEAL ICES project

SECTION 3 -- RELATIONSHIP OF THE HEAL ICES PROJECT TO LAND USE PLANS

3.01 Federal agencies

3.02 State agencies

3.03 Local agencies

SECTION 4 -- THE PROBABLE IMPACTS OF THE HEAL ICES PROJECT ON THE ENVIRONMENT

4.01 Nature of impacts -- general

4.02 Beneficial and adverse impacts

4.03 Secondary Impacts 
SECTION 5 -- ANY PROBABLE ADVERSE ENVIRONMENTAL EFFECTS WHICH CANNOT BE AVOIDED

SECTION 6 -- ALTERNATIVES TO THE HEAL ICES PROJECT

SECTION 7 -- THE RELATIONSHIP BETWEEN LOCAL SHORT-TERM USES OF MAN'S ENVIRONMENT AND THE MAINTENANCE AND

ENHANCEMENT OF LONG-TERM PRODUCTIVITY

SECTION 8 -- ANY IRREVERSIBLE AND IRRETRIEVABLE COMMITMENT OF RESOURCES WHICH WOULD BE INVOLVED SHOULD THE HEAL ICES PROJECT BE INSTITUTED

SECTION 9 -- OTHER INTERESTS AND CONSIDERATIONS OF FEDERAL POL ICY THAT OFFSET THE ADVERSE ENVIRONMENTAL EFFECTS OF THE HEAL ICES PROJECT

SECTION 10 - COORDINATION, COMMENT AND RESPONSE

10.01 Public participation

10.02 Government agencies

10.03 Citizens groups

BIBL IOGRAPHY 


\subsection{General}

This is a central energy system. Steam and chilled water will be produced at a central plant and distributed through a piping system to users in the immediate vicinity. Steam for these purposes will be generated in boilers that will be capable of using natural gas, oil and coal as fuel, with the added possibility of burning processed refuse also. Electricity, which will be generated as a byproduct in the central plant, will be used for plant auxiliaries, with the excess, when available, being fed into the electric grid of the local utility company, New Orleans Public Service Inc.

\subsection{Location of Project Area}

The project is located within the Louisiana Medical Complex (LMC) in the Central Business District of New Orleans, as shown on the Master Site Location Map (Exhibit 1) and the Composite Site Plan (Exhibit 2). The users of the central energy system will be member institutions of the Louisiana Medical Complex.

\subsection{Purpose, Plan and Status}

The purpose of the project is to provide a central system of thermal utilities for LMC institutions in an energy-efficient, feasible manner, for existing installations and for planned future facilities. Initial plant construction will accommodate anticipated thermal demands for al1 buildings that are expected to be functioning in year 1982, the target date for plant construction completion. Plant layout and distribution main capacities will allow for future accommodation of further LMC expansion and consequent increases in thermal demands. The project is currently in the phase identified as final feasibility and preliminary design, to be followed by final design and eventual construction.

\subsection{Operation and Maintenance}

The plant and its systems will be operated and maintained by New Orleans Public Service, Inc. (NOPSI), the local utility, under a lease agreement with the owner, Health Education Authority of Louisiana (HEAL), which is an agency of the State of Louisiana and functions in a coordinating capacity for the medical institutions within the Louisiana Medical Complex.

\subsection{Authorization}

This project has been developed under the sponsorship of the U.S. Department of Energy, which has provided the funding for the preliminary phases, in order to develop a program to demonstrate efficient use of energy by utilizing so-called waste or exhaust heat from production of electrical power, in the production of thermal utilities -- in this case, steam and chilled water. The electricity is a byproduct, and the electrical generation is governed by the requirements of the thermal utilities. 


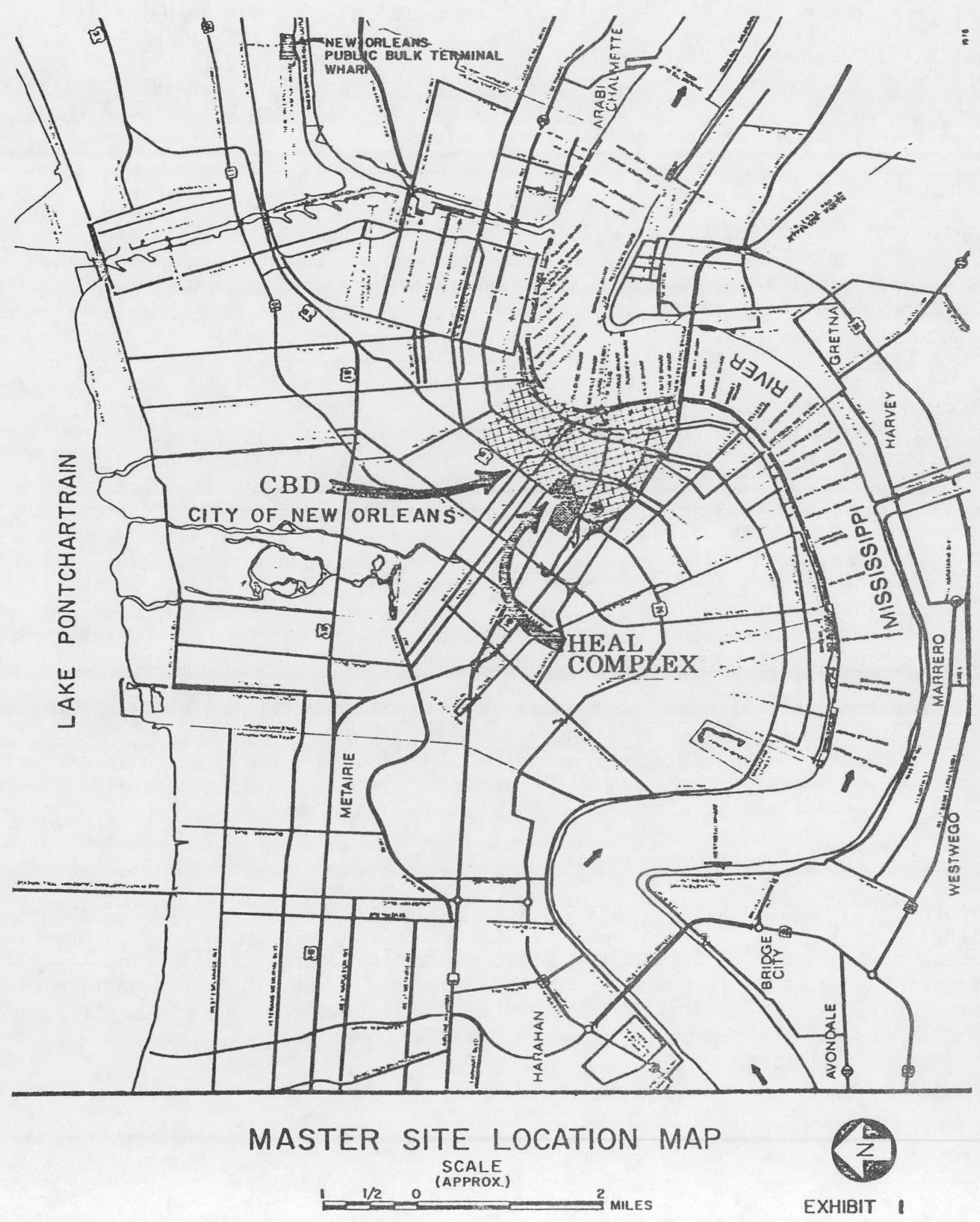




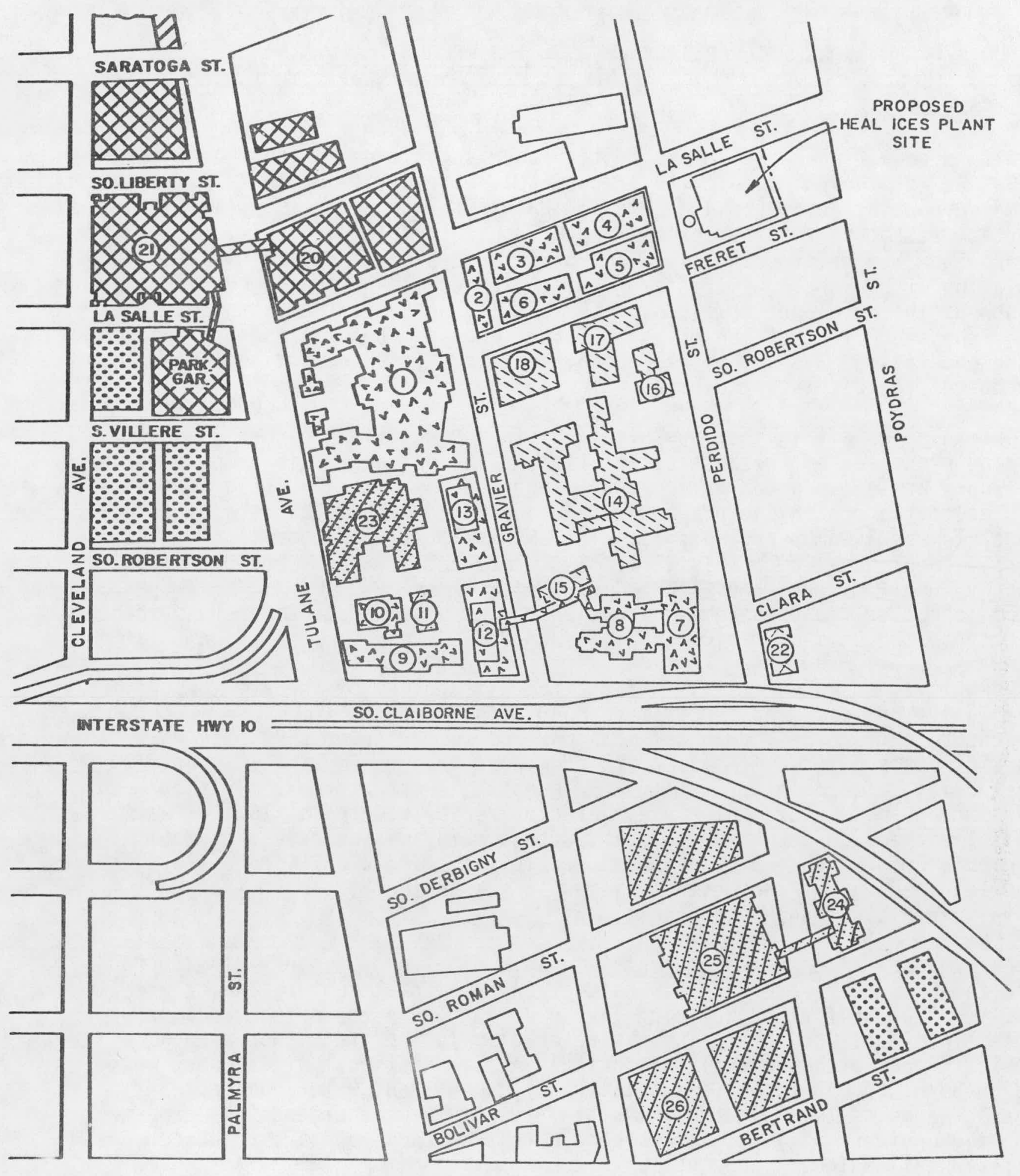

[E. CHARITY HOSPITAL

EYE, EAR, NOSE \& THROAT HOSP.
LSU MED. CENTER
$\because \because$ HEAL

VV VETERANS ADMIN.

$\triangle$ TUlane MED. CENTER
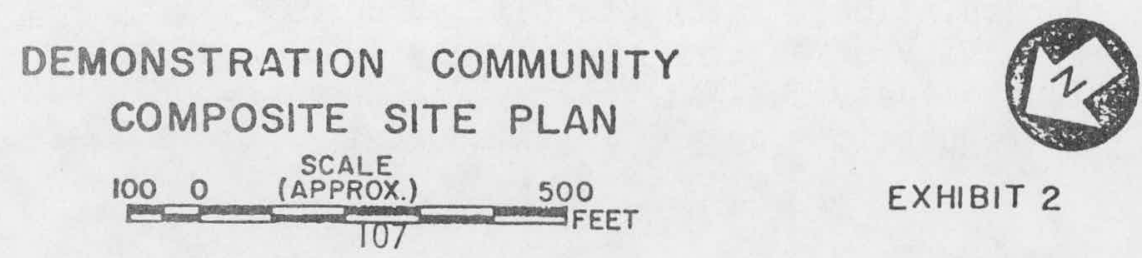

EXHIBIT 2 
SECTION 2 -- ENVIRONMENTAL SETTING WITHOUT THE PROJECT

\subsection{General}

The City of New Orleans (which is contiguous with Orleans Parish) contains 125,622 acres, including portions of navigable waterways, and in 1975 had an estimated population of 605,441 (Air and Water Quality Analysis, (A\&WQA)). This analysis, recently prepared for the New Orleans City Planning Commission divides Metropolitan New Orleans into 16 planning districts and describes 1 and use and population within these districts. Residential areas are scattered fairly evenly throughout the developed portions of the City. The Central Business District (CBD), the specific location of this project, houses the smallest percentage of the population, $3.8 \%$ (but has the highest population density), and employs over $40 \%$ of the City's work force.

New Orleans lies within the low Deltaic Plain formed by the natural 1 andbuilding processes of the Mississippi River. The Deltaic Plain is part of the Quaternary Lowlands formed during the Recent Epoch. Characteristic topographic features of the region include active and abandoned stream channels, their natural levees, swamps and marshes. The CBD is located on a portion of the natural levee. New Orleans is virtually surrounded by water, bounded on the north by Lake Pontchartrain with several other lakes located within a 25 mile radius in easterly and westerly directions. The Mississippi River runs through the city to the Gulf of Mexico, 55 miles to the South.

This proximity to water greatly affects the climatology of the area, specifically the relative humidity and temperature conditions, and decreases the range between temperature extremes. The annual mean maximum temperature is $77.6^{\circ} \mathrm{F}$, while the mean minimum is $60.4^{\circ} \mathrm{F}$. (Moise). From June through September, sporadic, almost daiTy, afternoon thundershowers keep the temperature from rising much above $90^{\circ} \mathrm{F}$. The winter months are characterized by alternate flows of warm tropical air and cold continental air, with a rainy season extending from midDecember to mid-March. A mean annual precipitation of 57.67 inches characterizes New Orleans as one of the wettest cities in the United States (Moise). Snowfalls are small and infrequent.

As the proposed site of the project is within an already densely constructed area, the CBD, there are very few natural environmental features which are likely to be impacted by further building in the area. There are neither natural wildlife habitats nor vegetation characteristic to the area. Nor are there any significant archeological, historical or recreational sites which would need to be disturbed to implement this action. Air and water quality, and perhaps the noise level in the immediate vicinity of the project are expected to be the environmental farameters of greatest concern, and are discussed in greater detail below.

\subsection{Air Quality}

The U.S. Environmental Protection Agency has determined a set of national air quality standards to minimize the adverse effects of air pollution on the general population. These standards prohibit further significant degradation of the air quality of an area and in many instances require improvements of existing conditions. Individual states may, at their own discretion, impose more stringent regulations on pollution sources. Tables I, II, and III are the 
Federal and State of Louisiana Ambients Air Quality Standards, respectively. The Louisiana Air Control Commission (LACC) is that body charged with the responsibility for maintaining the air quality of the state. Tables IV and $V$ are the results of this agency's monitoring program for 1976. Although the monitoring network extends throughout Louisiana, only those data collected in New Orleans are included here. Ozone levels are monitored continuously and the soiling index is measured at the State Office Building, 325 Loyola Avenue. Total suspended particulates (TSP) are monitored at several locations throughout the city, as indicated on Table $V$, and sulfur dioxide $\left(\mathrm{SO}_{2}\right)$ and nitrogen dioxide $\left(\mathrm{NO}_{2}\right)$ are measured at the Civill Court Building, 421 Loyola Avenue. Monitoring data for 1976 and 1977 show that the New Orleans area complies with National Ambient Air Quality Standards for all measured parameters except photochemical oxidants.

As published in the Federal Register, March 3, 1978 (43FR8998), Orleans Parish is designated as a non-attainment area for photochemical oxidants (as were 102 other urban areas in the U.S. with population exceeding 200,000). The Air Quality Control Region 106 in which Orleans Parish is located is designated as an attainment area for Total Suspended Particulates (TSP) and Sulfur Dioxide $\left(\mathrm{SO}_{2}\right)$ and is unclassified with respect to Carbon Monoxide (CO) and Nitrogen Dioxide $\left(\mathrm{NO}_{2}\right)$. The purpose of these clarafications is to provide guidance in air quality improvement. Specifically, in attainment areas, any new sources of pollution must meet the requirements of the State Implementation Plan for air quality improvement which in turn is required to assure the prevention of significant air quality deterioration (PSD). Prevention of significant deterioration means that the ambient air pollutant concentrations shall not increase more than a certain designated "increment" over the baseline concentrations. These "increments" are identified in the federal PSD regulations in the Federal Register, June 19, 1978 (43FR26384). In no case shall the ambient air quality exceed either of the National Ambient Air Quality Standards.

Exhibit 3 and Table VI identify the major stationary sources of air pollution in the Greater New Orleans area. The source numbers on this table correspond to the source points on Exhibit 3. These sources include industrial, construction, grain transfer, and power generating operations, and their support facilities. These sources may emit carbon monoxide, oxides of nitrogen and sulfur, particulate matter, hydrocarbons, and to a lesser degree, a variety of other organic and inorganic gases and vapors. The pollutant (or pollutants) emitted are, of course, dependent upon the industry involved. Table VI includes an inventory of pollutant emissions which can affect the air quality of the New Orleans area. This inventory was compiled from Emission Inventory Questionnaires on file with the Louisiana Air Control Commission.

Carbon monoxide, hydrocarbons, nitrogen oxides and photochemical oxidants are the principal pollutants associated with vehicular traffic. Residential pollutants result primarily from home heating systems. As the major home heating fuel in the area is natural gas, pollution from residences is negligible with respect to the air quality of the area.

Exhibit 4 is an annual wind rose for the New orleans area, developed by the U.S. Public Health Service (MOISE). It shows the predominant wind direction throughout the year as coming from the south. Southerly winds are beneficial to the city in that much of the New Orleans air pollution is carried out over Lake Pontchartrain and sparsely populated areas north of the lake. Similarly, northerly winds can carry the pollution across the state and out over the Gulf of Mexico. 


\section{FEDERAL REGULATIONS}

\section{AIR POLLUTION}

POLLUTANT

$\mathrm{SO}_{2} \underset{\text { (primary })^{\mathrm{T}}}{\text { (secondary })}$ ?

$\begin{array}{rr}\text { Particulate (1) } & 75 \mathrm{ug} / \mathrm{m}^{3} \\ \text { (2) } & 60 \mathrm{ug} / \mathrm{m}^{3}\end{array}$

CO

(1) \& (2) $10 \mathrm{mg} / \mathrm{m}^{3}-8 \mathrm{hr} .40 \mathrm{mg} / \mathrm{m}^{3}-1 \mathrm{Hr}$.

0xidants

Hydro-

cartons

$\mathrm{NO}_{2}$
ANNUAL AVG.

24 HR. MAX./YR.

$365 \mathrm{ug} / \mathrm{m}^{3}$
$260 \mathrm{ug} / \mathrm{m}^{3}$

$260 \mathrm{ug} / \mathrm{m}_{3}^{3}$

150. ug $/ \mathrm{m}^{3}$
3 HR. MAX./yr.

$1300 \mathrm{ug} / \mathrm{m}^{3}$ 
TABLE II

STATE OF LOUISIANA

PRIMARY - AMBIENT AIR QUALITY STANDARDS

\section{STANDARDS}

AIR CONTAMINANT MAXIMUM PERMISSIBLE CONCENTRATION

Suspended Particulate

$75 \mathrm{ug} / \mathrm{m}^{3}{ }_{3}$ (Annual geometric mean)

$260 \mathrm{ug} / \mathrm{m}^{3}$ (Maximum $24 \mathrm{hr}$. concentration not be exceeded more than once per year)

Dustfal1

20 tons per square mile per month.

Coefficient of Haze

0.6 (coh/1000 linear feet) (annual geo. mean)

0.75 (coh/1000: linear feet) (annual arith. mean)

1.50 (coh/1000 linear feet) ( $24 \mathrm{hr}$. average)

$\Xi$ Sulfur Dioxide $\quad\left(\mathrm{SO}_{2}\right)$

$80 \mathrm{ug} / \mathrm{m}^{3}$ or $0.03 \mathrm{ppm}$ (annual arith. mean)

$365 \mathrm{ug} / \mathrm{m}^{3}$ or $0.14 \mathrm{ppm}$ (Maximum $24 \mathrm{hr}$. concentration not to be exceeded more than once per year)

Sulfur Acid Mist

Sulfur Trioxide, or any

$4 \mathrm{ug} / \mathrm{m}_{3}^{3}$ (Maximum annual average)

combination therof

$12 \mathrm{ug} / \mathrm{m}_{3}^{3}$ ( $24 \mathrm{hr}$. average, not to be exceeded over $1 \%$ of the time)

$30 \mathrm{ug} / \mathrm{m}^{3}$ ( $1 \mathrm{hr}$. average, not to be exceeded over $1 \%$ of the time)

Carbon Monoxide (CO)

$10,000 \mathrm{ug} / \mathrm{m}^{3}$ or $9 \mathrm{ppm}$ (Maximum $8 \mathrm{hr}$. concentration not to be exceeded more than once per year)

$40,000 \mathrm{ug} / \mathrm{m}^{3}$ or $35 \mathrm{ppm}$ (Maximum $1 \mathrm{hr}$. concentration not to be exceeded more than once per year) 
TABLE II - CONT'D

STATE OF LOUISIANA

PRIMARY - AMBIENT AIR QUALITY STANDARDS

STANDARDS

AIR CONTAMINANT

* Hydrocarbons (other than Methane)

Total Oxidants

MAXIMUM PERMISSIBLE CONCENTRATION

$160 \mathrm{ug} / \mathrm{m}^{3}(0.24 \mathrm{ppm})$ (Maximum $3 \mathrm{hr}$. concentration not to be exceeded more than once per year)

$58.8 \mathrm{ug} / \mathrm{m}_{3}^{3} 0.03 \mathrm{ppm}$ (annual arith. mean)

$98.0 \mathrm{ug} / \mathrm{m}^{3} 0.05 \mathrm{ppm}$ ( $4 \mathrm{hr}$. maximum)

$160 \mathrm{ug} / \mathrm{m}^{3} 0.08 \mathrm{ppm}$ (maximum $1 \mathrm{hr}$. concentration not to be exceeded more than once per year)

$\vec{\sim}$ Nitrogen Dioxide $\left(\mathrm{NO}_{2}\right)$

$100 \mathrm{ug} / \mathrm{m}^{3}$ (0.05 ppm) (annual arith. mean) 
TABLE III

STATE OF LOUISIANA

SECONDARY - AMBIENT AIR QUALITY STANDARDS

STANDARDS

AIR CONTAMINANT

MAXIMUM PERMISSIBLE CONCENTRATION

$\begin{array}{ll}\text { Suspended Particulate } & 60 \mathrm{ug} / \mathrm{m}^{3} \\ & 150 \mathrm{ug} / \mathrm{m}^{3} \text { (Maxnual geometric mean) } \\ \text { more than once per year) }\end{array}$

Sulfur Dioxide $\left(\mathrm{SO}_{2}\right)$

$60 \mathrm{ug} / \mathrm{m}^{3}$ or $0.02 \mathrm{ppm}$ (Annual arith. mean)

$260 \mathrm{ug} / \mathrm{m}^{3}$ or $0.10 \mathrm{ppm}$ (Maximum $24 \mathrm{hr}$. concentration not to be exceeded more than once per year)

$1300 \mathrm{ug} / \mathrm{m}^{3}$ (Maximum $3 \mathrm{Hr}$. concentration not to be exceeded more than once per year)

$\vec{\omega}$

Carbon Monoxide

$10,000 \mathrm{ug} / \mathrm{m}^{3}$ or $9 \mathrm{ppm}$ (Maximum $8 \mathrm{hr}$. concentration not to be exceeded more than once per year)

Total Oxidants

$58.8 \mathrm{ug} / \mathrm{m}_{3}^{3} 0.03 \mathrm{ppm}$ (annual arithmetic mean)

$98.0 \mathrm{ug} / \mathrm{m}^{3} 0.05 \mathrm{ppm}$ (4 $\mathrm{hr}$. Maximum)

$160 \mathrm{ug} / \mathrm{m}^{3} 0.08 \mathrm{ppm}$ (Maximum $1 \mathrm{hr}$. concentration not to be exceeded more than once per year)

Nitrogen Dioxide $\left(\mathrm{NO}_{2}\right)$

$100 \mathrm{ug} / \mathrm{m}^{3}$ (0.05 ppm) (annual arithmetic mean) 
TABLE IV

LOUISIANA AIR CONTROL COMMISSION

STATISTICAL SUMMARY OF HOURLY OZONE CONCENTRATIONS IN NEW ORLEANS

\begin{tabular}{|c|c|c|c|c|c|}
\hline \multirow[b]{2}{*}{$\underline{\text { YEAR }}$} & \multirow[b]{2}{*}{$\begin{array}{l}\text { MAXIMUM HOURLY } \\
\text { CONCENTRATION, ppm }\end{array}$} & \multirow{2}{*}{$\begin{array}{l}\text { ANNUAL ARITHMETIC } \\
\text { MEAN HOURLY } \\
\text { CONCENTRATION, ppm }\end{array}$} & \multirow[b]{2}{*}{$\begin{array}{l}\text { STANDARD } \\
\text { DEVIATION, ppm }\end{array}$} & \multicolumn{2}{|c|}{ HOURLY OBSERVATIONS } \\
\hline & & & & $\begin{array}{l}\text { HOURLY } \\
\text { INUMBER } \\
\end{array}$ & $\begin{array}{l}\% \text { OF HOURS } \\
\text { IN YEAR } \\
\end{array}$ \\
\hline 1976 & 0.178 & 0.016 & 0.012 & 409.1 & 47 \\
\hline 1977 & 0.120 & 0.014 & 0.016 & 7430 & 85 . \\
\hline
\end{tabular}

$\exists$ 
TABLE V

LOUISIANA AIR CONTROL COMMISSION

(1976) \& 1977 YEARLY REPORT OF AIR POLLUTANTS IN NEW ORLEANS

\begin{tabular}{|c|c|c|c|c|c|c|}
\hline PARAMETER & $\begin{array}{l}\text { HIGHEST } \\
\text { VALUE } \\
\mathrm{ug} / \mathrm{m}^{3} \\
\end{array}$ & $\begin{array}{l}\text { SECOND } \\
\text { HIGHEST } \\
\text { VALUE, } \mathrm{ug} / \mathrm{m}^{3}\end{array}$ & $\begin{array}{l}\text { NUMBER } \\
\text { OF } \\
\text { SAMPLES* }\end{array}$ & $\begin{array}{l}\text { ANNUAL } \\
\text { MEAN**, } \mathrm{ug} / \mathrm{m}^{3}\end{array}$ & $\begin{array}{l}\text { NUMBER } \\
\text { OF } \\
\text { PRI. VIO. }\end{array}$ & $\begin{array}{l}\text { NUMBER } \\
\text { OF } \\
\text { SEC: VIO. }\end{array}$ \\
\hline $\mathrm{SO}_{2}$ & (6) 14 & (6) 13 & $(67) 58$ & $(1.3) 2.1$ & (0) 0 & (0) 0 \\
\hline $\mathrm{NO}_{2}$ & (48) 90 & $(46) 90$ & $(61) 61$ & $(19.4) 38.7$ & (0) 0 & (0) 0 \\
\hline \multicolumn{7}{|l|}{$\underline{\text { TSP: }}$} \\
\hline Algiers Pumping Sta. & (68) & $(63) 87$ & (55) 56 . & (40) 35 & (0) 0 & (0) 0 \\
\hline Civil Courts Bldg. & $(119) 147$ & $(115) 146$ & $(57) 60$ & (62) 59 & (0) 0 & (0) 0 \\
\hline Fire Station \#45 & $(90) 131$ & (77) $70^{\circ}$ & (48) 59 & (37) 37 & (0) 0 & (0) 0 \\
\hline Pumping Station \#3 & $(176) 144$ & $(118) 126$ & $(55) 54$ & $(60) 69$ & $(0) 0$ & (1) 0 \\
\hline Pumping Station \#4 & $(97) 136$ & (67) 90 & ( 37$) 57$ & (40) 44 & (0) 0 & (0) 0 \\
\hline $\begin{array}{l}\text { Water Purification } \\
\text { Plant }\end{array}$ & (126) 105 & (119) 98 & $(36) 30$ & (67) 56 & (0) 0 & (0) 0 \\
\hline Woodland Place & (126)136 & $(122) 130$ & ( 52) 57 & (57) 45 & (0) 0 & (0) 0 \\
\hline
\end{tabular}

* Samples taken every six days if possible.

** Arithmetic Mean for $\mathrm{SO}_{2}, \mathrm{NO}_{2}$ Geometric Mean for TSP. 


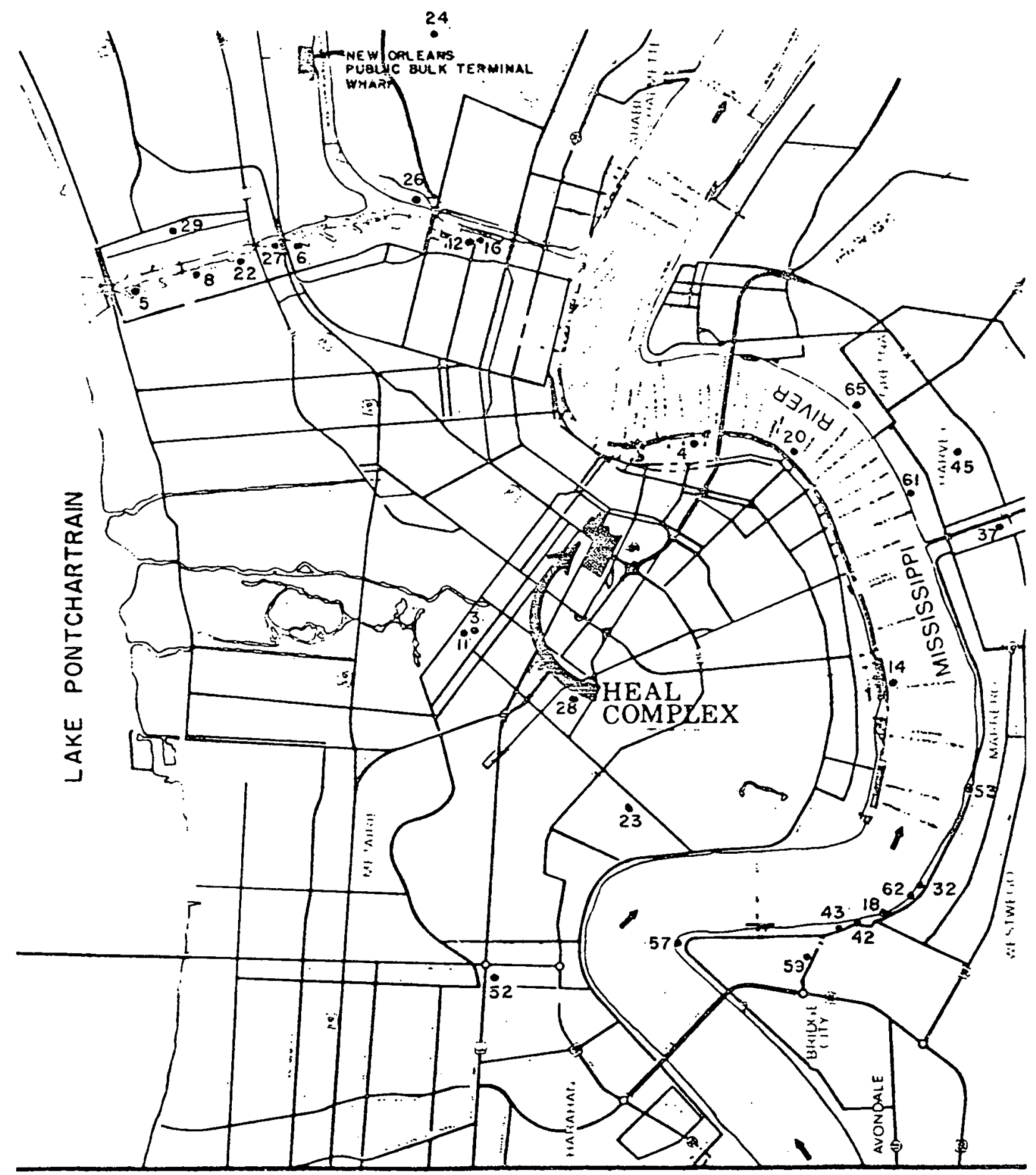

MAJOR STATIONARY SOURCES OF AIR POLLUTION IN THE NEW ORLEANS AREA SCALE

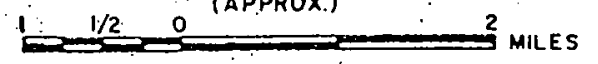

(SEE TABLE VI FOR DESCRIPTIVE LIST OF SOURCES) 
TABLE VI Inventory of Major Emlssions Sources in Orleans Parish and Surrounding Areas Expected to Contribute to the Alr Quelity of New Orleans, Loula1ann. (1975 Data)

Total Plant Fimtentong (Ioum por Yoar)

$\mathrm{SO}_{2}$

\section{ORLEANS PARISH}

1. A1r Products and Chemicals; Inc.

2. All1s Chalmer Corporation

3. American Can Co.

4. American Coffee

5. Barold Divialon, National Lead

6. Boh Brothers Construction

7. Consolidated Materials

8. Dresser Minerals

9. Dundee Cement

10. Folger Coffee Co.

$\exists \quad 11$. Inland Steel Container Co.

12. Johns-Manville Products

13. Loulsiana Cement

14. Public Graln Elevator

15. Bulk Cement Terminal

16. Lone Star Industries

17. Milchem Inc.

18. National Gypsum Co.

19. New Orleans Bulk Terminal (info not available)

20. NOPSI, Market St.

21. NOPSI, Michoud Steam

.21

22. NOPSI, A.B. Paterson Steam

7.26

23. N.0. Sewerage \& Water, Power House $\# 2$

28.19

24. N.0. Sewerage \& Water, East Bank Treatment --

25. Owens-Illinois, Plant \#8

26. Southern Scrap

27. Standard Brands

28. Thompson-Hayward Chemical

29. U.S. Gypsum

\section{0}

0.3

$--$

140.2
Porticulated

No

co

Hydrocarbons

\begin{tabular}{lc}
12.8 & 762 \\
-1.43 & \multicolumn{2}{c}{458} \\
-- & -- \\
-- & -015 \\
-- & -- \\
-- & -- \\
-14 & -- \\
-- & -- \\
.27 & -- \\
3.9 & 135.9 \\
-- & -- \\
-- & -- \\
-- & -- \\
-- & -- \\
.19 & -- \\
-- & -- \\
5.97 & -- \\
06.4 & \\
47.28 & 98.3 \\
88.1 & 14.71 \\
-- & 22.06 \\
-- & .217 \\
-- & .191 \\
-- & -- \\
- & -- \\
10.48 & -- \\
& --
\end{tabular}


Total Plant Emissions (Tons per Year)

Source

\section{JEFFERSON PARISH}

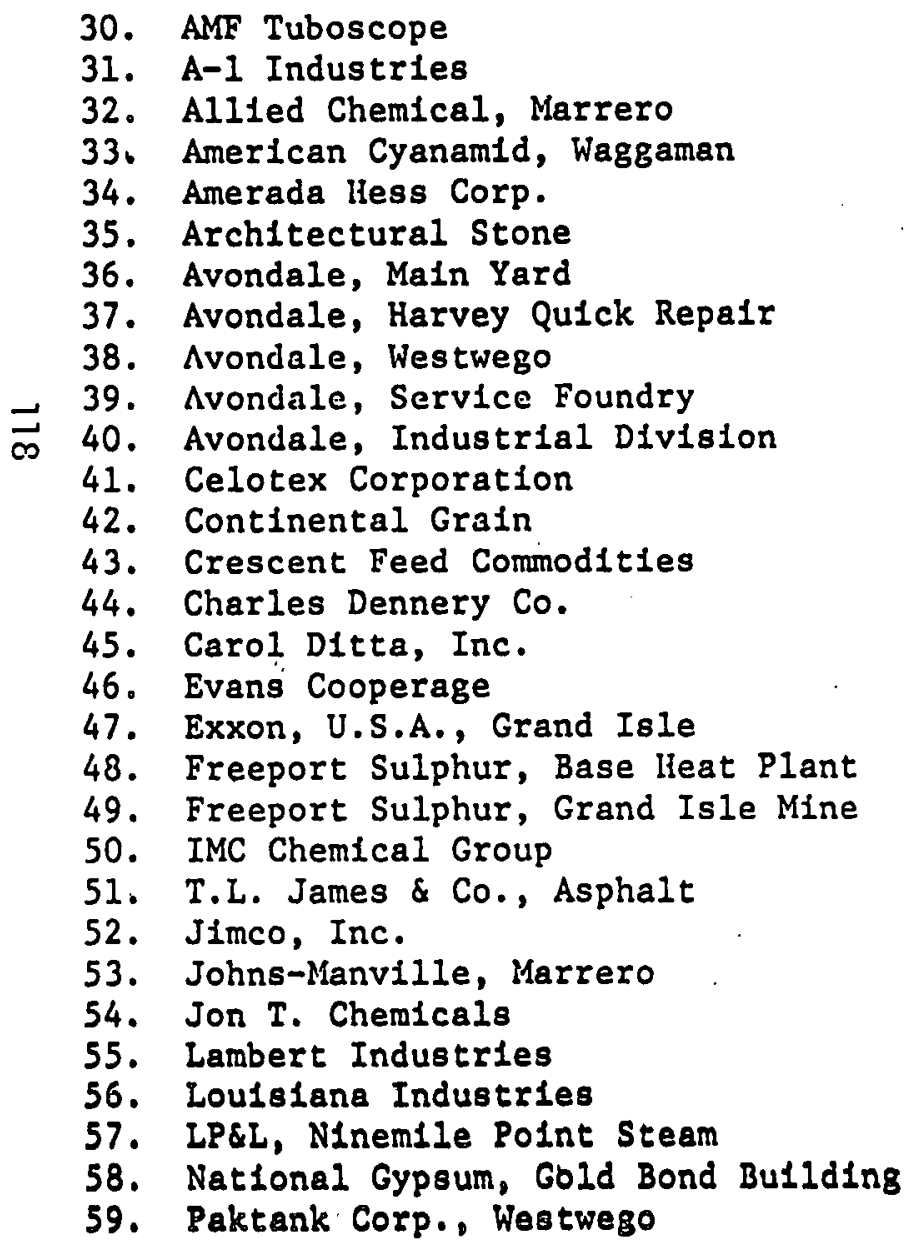

$\mathrm{SO}_{2}$

Particulates

NO

co

Hydrocarbons

\begin{tabular}{|c|c|}
\hline- & \\
\hline$=$ & 1.24 \\
\hline$\overline{0} .007$ & 1.83 \\
\hline 1925 & $\begin{array}{r}1.9 \\
155.9\end{array}$ \\
\hline .59 & .1 \\
\hline .06 & .04 \\
\hline .07 & 41.3 \\
\hline $7.8 E$ & .612 \\
\hline 0.02 & 31.1 \\
\hline-- & 23.3 \\
\hline .001 & 7.7 \\
\hline 215.8 & 171 \\
\hline- & 13.5 \\
\hline .84 & 13.68 \\
\hline-- & .012 \\
\hline-- & 2.06 \\
\hline 23.5 & 427 \\
\hline .7 & 1.6 \\
\hline .004 & .18 \\
\hline 10.8 & 50.2 \\
\hline-- & 179.1 \\
\hline$-\infty$ & 21.96 \\
\hline- & 1.4 \\
\hline .043 & 1.94 \\
\hline-- & - \\
\hline-- & 10.5 \\
\hline-- & 1 \\
\hline 3609 & 9.36 \\
\hline $22^{.13}$ & $\frac{81.24}{5}$ \\
\hline
\end{tabular}

\begin{tabular}{|c|c|}
\hline-- & 1 \\
\hline-- & - \\
\hline-- & - \\
\hline 11500 & 15600 \\
\hline$<.001$ & 297.3 \\
\hline .014 & - \\
\hline $\begin{array}{l}1.9 \\
1.3\end{array}$ & 11.4 \\
\hline 1.22 & 5.7 \\
\hline- & -- \\
\hline .0019 & 1.1 \\
\hline-- & .007 \\
\hline-- & -- \\
\hline .0448 & -- \\
\hline .02 & .0036 \\
\hline- & - \\
\hline 726 & 12.8 \\
\hline 14.5 & 7.9 \\
\hline 29.8 & $\begin{array}{l}.026 \\
5.3^{\circ}\end{array}$ \\
\hline- & - \\
\hline- & - \\
\hline- & - \\
\hline 2.07 & .207 \\
\hline -- & - \\
\hline$-\infty$ & $-\infty$ \\
\hline- & $-\infty$ \\
\hline 841 & 106 \\
\hline$=$ & $=$ \\
\hline 1,3 & 491 \\
\hline
\end{tabular}

(continuad) 
TABLE VI Continued.

Total Plant Em.laglons (Tonk per Yenr)

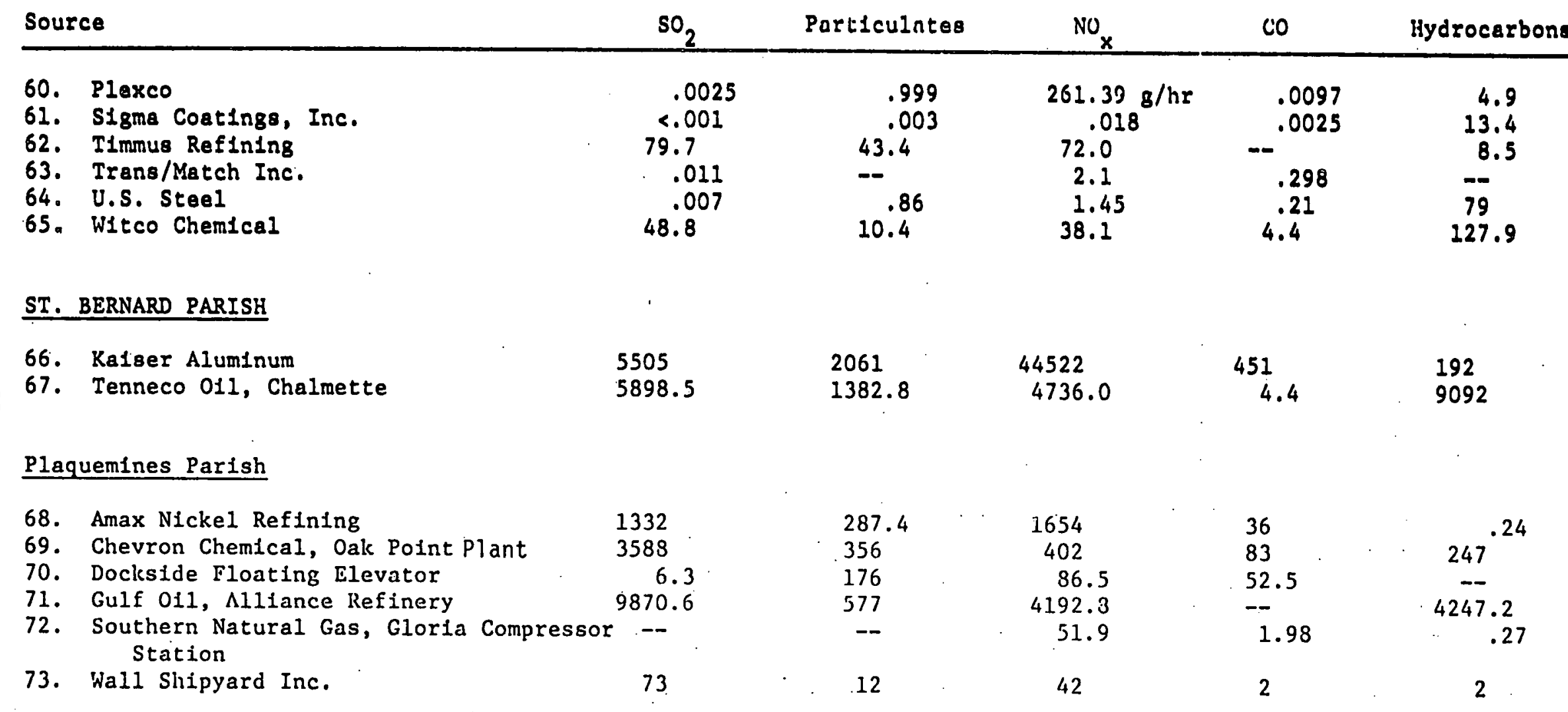



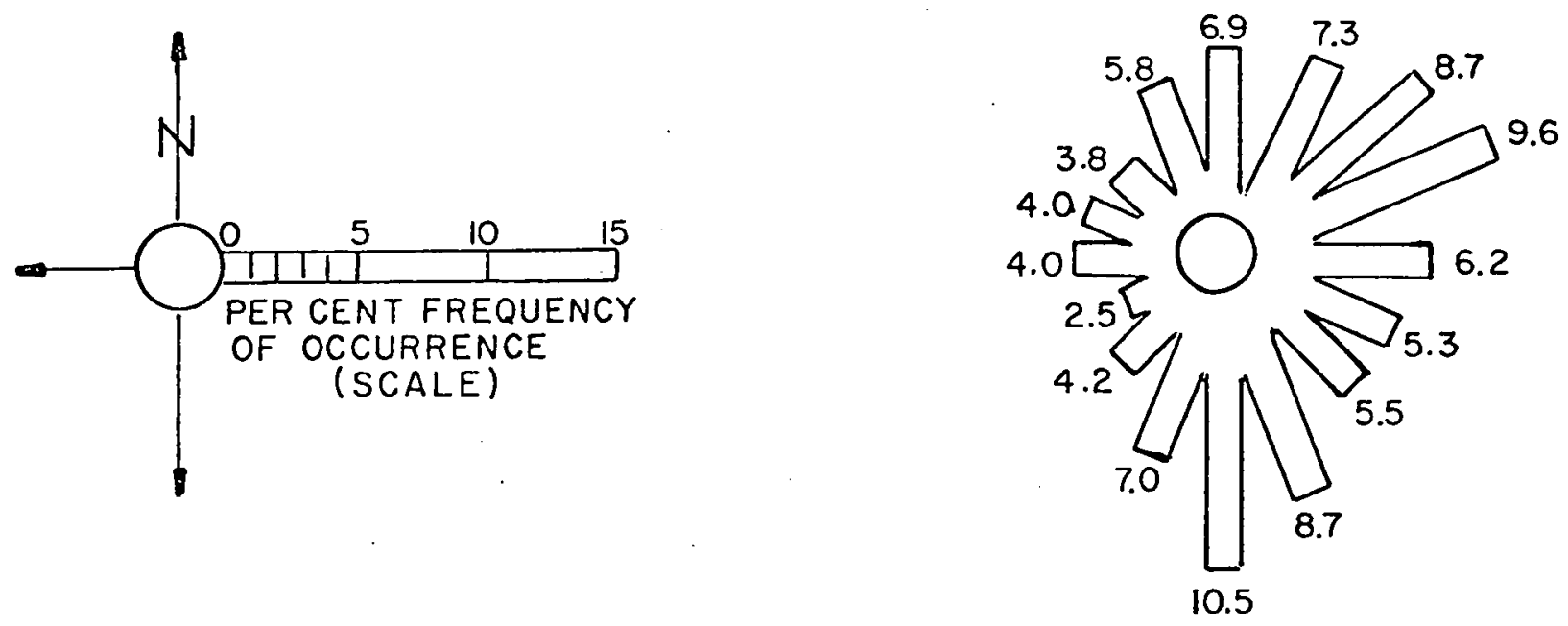

ANNUAL PERCENT

OCCURRENCE

(DIRECTION)

\section{ANNUAL DIRECTIONAL WIND ROSE \\ FOR NEW ORLEANS}




\subsection{Water Quality}

The State of Louisiana has classified that segment of the Mississippi River flowing through New Orleans as water quality limited due primarily to violations of taste and odor standards. Several other parameters also exceed pertinent water quality standards, including both total and fecal coliform, suspended solids, several heavy metals, ammonia, and pesticides (A \& WQA). The 1969-1970 EPA study upon which this classification was based also found 36 trace organic compounds, including several other pesticides to be present in the river water. This water quality limited status allows for usage of the river water for secondary contact, fish and wildlife propagation, and domestic water supply only.

The quality of the water is influenced by numerous industrial discharges, as well as accidental spills of petroleum, petrochemical and chemical materials, not only within the reach of Orleans Parish, but also far above: the Lower Mississippi River Basin (to which this part of the river belongs) drains $40 \%$ . of the continental United States. This is an area of 1,228,900 square miles (A\&WQA) of urban and agricultural run off and industrial and sewerage discharges. Yet the river is not used for drainage once it reaches Orleans Parish. This is because much of the urban development in and around metropolitan New Orleans is on sites which are near or below sea level. To protect these areas from river flood waters and storm-driven tidal surges, an extensive levee system has been constructed. While preventing surface waters from flooding these areas, the levees necessitate artificial removal of a 11 precipitation falling within their bounds. This removal is effected by an elaborate system of drainage canals, subsurface drainage and pumping stations. Since the land slopes away from the river on both banks, all urban runoff is pumped into either Lake Pontchartrain or Barataria Bay (MRBR).

Within the confines of Orleans Parish, the Mississippi River is used as a source of domestic raw water supply for nearly one million people. Industry withdraws nearly 2 billion gallons per day, mainly for use as cooling water, and the river is used to carry both industrial and municipal wastes (MRBR).

To protect the quality of the receiving waters, (Mississippi River, Lake Pontchartrain and Barataria Bay), the New Orleans Sewerage and Water Board has established statutes governing discharges into the storm drainage system and into the sanitary sewerage system. As this project is expected to discharge directly into the storm drainage system, only those rules are presented here, and may be found in Table VII. No discharge from this proposed plant will enter Barataria Bay.

As the proposed facility is located on the East Bank of the Mississippi River, effluents from it would eventually reach Lake Pontchartrain. The lake is water quality limited with respect to coliform levels, and has been divided into two segments by the State of Louisiana for water use designations (A\&WQA). East of Highway 11, the lake is classified suitable only for shellfish, fish, and wildlife propagation, while west of Highway 11 , the lake may be used for not only fish and wildlife propagation but also primary contacts for recreation.

Drainage waters introduced to the lake are of very poor quality with respect to coliforms, biochemical oxygen demand (BOD), nutrients, suspended solids and dissolved oxygen. These waters also contain metals in concentrations termed "hazardous" to the marine environment by the U.S.E.P.A. ( $A$ \& WQA). 
The contamination is directly attributable to urban runoff and effluent from municipal and industrial treatment facilities. The quality of the "first flush" of storm water is analogous to that of domestic sewage (A\&NQA), and that water, plus water from broken, cracked and inadequate sewerage lines which seeps into the drainage lines, drains untreated into Lake Pontchartrain. 
TABLE VII

\section{RULES GOVERNING DISCHARGES INTO THE PUBLIC STORM DRAINAGE SYSTEM}

\section{(a) GENERAL}

(1) The public storm drainage system exists primarily to allow the removal of storm water runoff from public and private land surfaces, and will be referred to herein as the "storm drainage system". The control of pollution in said system and thus the receiving stream which ultimately receives storm drainage water is manifestly in the public interest:

(2) Liquid waste, such as industrial waste, cooling water discharge, water runoff from land surfaces other than resulting from precipitation, etc., may be admitted to the storm drainage system provided they are free of offens ive or objectionable pollutants within the limits hereinafter defined as applicable to discharges into the storm drainage system.

\section{(b) ALLOWABLE DISCHARGES: STORM DRAINAGE SYSTEM}

Liquid wastes may be admitted to the drainage system, upon securing permit, provided:

(1) The wastes do not exceed a B.O.D. loading of 25 pounds per day at a maximum concentration of $15 \mathrm{mg} / 1$.

(2) The wastes do not exceed a C.O.D. loading of 50 pounds per day at a maximum concentration of $30 \mathrm{mg} / 1$.

(3) The wastes do not contain suspended solids in excess of 42 pounds per day at a maximum concentration of $25 \mathrm{mg} / 1$.

(4) The wastes do not give off offensive odors.

(5) The wastes impart no significant coloration to the waters contained in the drainage system.

(6) The wastes do not cause an objectionable change in the $\mathrm{pH}$ of the waters contained in the drainage system.

(7) The wastes do not contain materials which form objectionable coatings on the sides or deposits on the bottoms of the drainage systems.

(8) The wastes do not exceed 110 degrees Fahrenheit or raise the temperature of the receiving canal by more than five $\left(5^{\circ}\right)$ degrees Fahrenheit.

(9) The wastes do not contain pathogenic bacteria or the indicator organisms of pathogenic bacteria in quantities greater than the densities prescribed by other agencies as the maximum limit for safe recreational contact waters.

(10) The wastes do not contain materials whose concentrations exceed the values in the following list, the analytical results being expressed in terms of the indicated element. 


$\begin{array}{ll}\text { Antimony } & 0.1 \\ \text { Arsenic } & 0.05 \\ \text { Barium } & 1.0 \\ \text { Beryllium } & 1.0 \\ \text { Bismuth } & 1.0 \\ \text { Boron } & 0.5 \\ \text { Cadmium } & 0.1 \\ \text { Chromium (Hexavalent) } & 0.05 \\ \text { Chromium (Trivalent) } & 0.05 \\ \text { Cobalt } & 0.2 \\ \text { Copper } & 0.5 \\ \text { Iron } & 1.0 \\ \text { Lead } & 0.1 \\ \text { Manganese } & 0.05 \\ \text { Mercury } & 0.01 \\ \text { Molybdenum } & 0.1 \\ \text { Nickel } & 0.5 \\ \text { Rhenium } & 0.5 \\ \text { Selenium } & 0.05 \\ \text { Silver } & 0.05 \\ \text { Strontium } & 0.5 \\ \text { Tellurium } & 0.5 \\ \text { Tin } & 1.0 \\ \text { Zinc } & 1.0\end{array}$

(11) The wastes do not contain cyanides or cyanogen compounds in excess of $0.1 \mathrm{mg} / 1$ as $\mathrm{CN}$ - in the discharged waste.

(12) The wastes do not contain radioactive materials exceeding the existing standards of the proper regulatory authority.

(13) The wastes do not contain phenols or other taste or odor producing substances in such concentrations as to affect the taste or ordor of the receiving stream.

(14) The wastes do not contain unusual concentrations of total dissolved solids (such as sodium chloride or sodium sulfate).

(15) The wastes do not contain hydrogen sulfide in excess of 1.0 $\mathrm{mg} / \mathrm{l}$ as sulfide ion.

(16) The wastes do not contain any phosphorus as ortho-phosphate ion in excess of $1.0 \mathrm{mg} / 1$.

(17) The wastes do not contain any foaming or frothing agents of a persistent nature.

(18) The dissolved oxygen of the waste is not less than $50 \%$ of saturation at the particular discharge temperature of the waste.

(19) The wastes do not contain inorganic nitrogen in the form of nitrite or nitrate ion in excess of $5.0 \mathrm{mg} / 1$.

(20) The wastes do not contain any substance considered or found to be toxic to aquatic life, such as, but not limited to, hydrocarbons, etc.

\section{(c) PROVISIONAL DISCHARGES: STORM DRAINAGE SYSTEM}

Liquid wastes which require pretreatment in order to attain the limits required for admission of the discharge to the storm drainage system will be allowed provided there is full compliance with the requirements of Section 16.3 - Rules Governing the Pretreatment of Liquid Waste Discharge into the Public Storm Drainage System and the Public Sanitary Sewerage System. 


\section{TABLE VII - continued}

It shall be expressly understood that the permit for a provisional discharge may be revoked, and the permitted connection to the storm drainage system terminated, at any time the General Superintendent adjudges that such revocation is necessary to protect the receiving streams of the storm drainage sys tem.

(16.3) RULES GOVERNING THE PRETREATMENT OF LIQUID WASTE DISCHARGES INTO THE PUBLIC STORM DRAINAGE SYSTEM AND THE PUBLIC SANITTARY SEWERAGE SYSTEM.

\section{(a) GENERAL}

The pretreatment of liquid wastes to attain the limits for admission to either the public storm drainage system or the publi.c sanitary sewerage system (as the case may be), will be allowed.

(b) DILUTION NOT ACCEPTABLE

The alteration of the characteristics of a polluted liquid waste, to attain the limits for admission to either the public sanitary sewerage system or the public storm drainage system (as the case may be), by means of dilution will not be allowed as an acceptable pretreatment process. The objective of an acceptable pretreatment process shall be the removal of the pollutant from the liquid waste.

PROCESS.

(c) SUBMISSION OF PLANS, SPECIFICATIONS AND DATA OF PRETREATMENT

In the event pretreatment of waters or wastes is required, then all plans, specifications and any other pertinent information relating to proposed treatment, processing facilities or flow equalization facilities, etc., shall be submitted for approval of the General Superinterdent prior to the start of construction, if the effluent from such facilities is to be discharged into the public sanitary sewerage system or the public storm drainage system (as the case may be). All such plans shall be prepared by a Registered Professional Engineer and shall bear his signature and seal. 


\subsection{Noise}

The potential impact on the area from the noise generated by this ICES needs to be quantitatively determined by surveys at the proposed site to determine the existing noise conditions throughout the day and the week and surveys of existing plants or components of the type proposed here. Whatever the determination is as a result of these surveys, adequate noise control measures can be taken to reduce the environmental impact to an insignificant level.

The noise survey data contained in Phase I Report is repeated here in the following table.

NOISE SURVEY IN HEAL AREA

SITE \#

5

5

6

6
TIME

$2: 45-2: 55$ P.M.

$2: 45-2: 55$ P.M.

$3: 15-3: 25$ P.M.

3:05 - 3:15 P.M.
DATE

7-9-74

10-7-77

7-9-74

10-7-77
NOISE LEVEL (dBA)

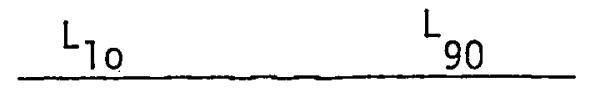

65

$\overline{58}$

The noise from site \#5 (Poydras at Bolivar) comes largely from traffic on Poydras Street. The site for this proposed ICES is in a block adjacent to Poydras Street. This gives an indication of the existing noise level in the vicinity of the proposed plant--at least in the daytime. Exhibit 5 depicts sound levels in the Central Business District measured in June, 1976, between 3:00 P.M. and 5:00 P.M. Table VI.II describes sound levels and their effect on human beings. This has been included to aid in understanding the levels of noise present. Determination of the noise suppression needed for the operating ICES will be possible after more time-distributed sound surveys in the area are completed. 


\section{EXISTING NOISE LEVELS CENTRAL BUSINESS DISTRICT NEW ORLEANS, LA.}

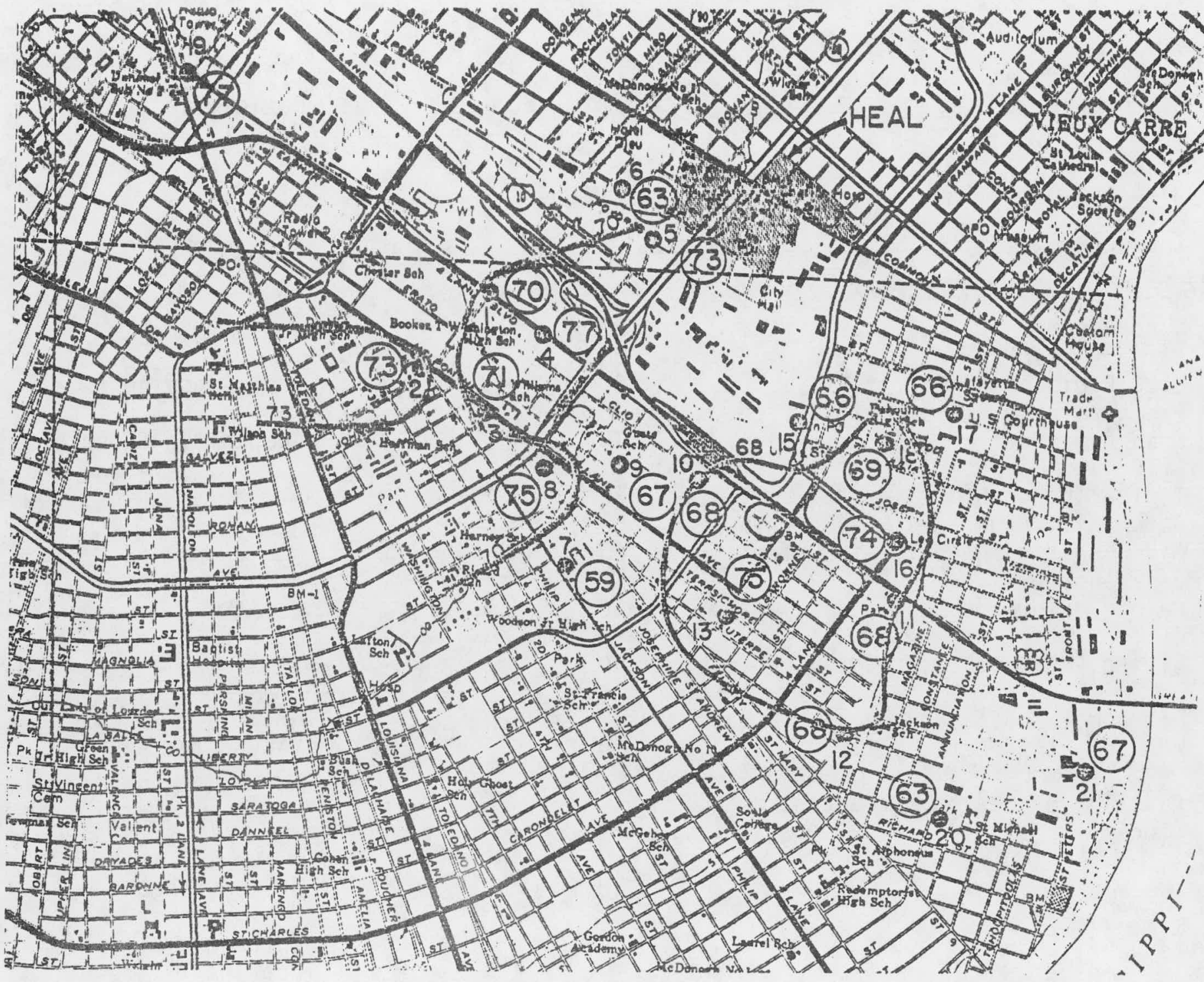

- location noISE measurment

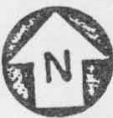

I3 LOCATION CODE NUMBER

(75) NOISE LEVEL dbA TAKEN BETWEEN

3:00 P.M. TO 5:00 P.M.

68 EXISTING NOISE CONTOUR

EXHIBIT 5 


\begin{tabular}{|c|c|c|}
\hline SOUND SOURCE & $\mathrm{dBA}$ & $\begin{array}{l}\text { TREND OF } \\
\text { RESPONSE }\end{array}$ \\
\hline & 130 & $\begin{array}{l}\text { Painfully Loud } \\
\text { Limit Amplified } \\
\text { Speech }\end{array}$ \\
\hline $\begin{array}{l}\text { Jet Takeoff at } 200 \text { Feet } \ldots \ldots \ldots \ldots \ldots \\
\text { Discotheque } \ldots \ldots \ldots \ldots \ldots \ldots \ldots \ldots\end{array}$ & $\begin{array}{l}120 \\
120\end{array}$ & $\begin{array}{l}\text { Maximum Vocal } \\
\text { Effort }\end{array}$ \\
\hline $\begin{array}{l}\text { Riveting Maching } \ldots \ldots \ldots \ldots \ldots \ldots \ldots \\
\text { Jet Takeoff at } 2,000 \text { Feet } \\
\text { Shout }(0.5 \text { feet }) \quad \ldots \ldots \ldots \ldots \ldots \ldots \ldots\end{array}$ & $\begin{array}{l}110 \\
100\end{array}$ & Very Annoying \\
\hline 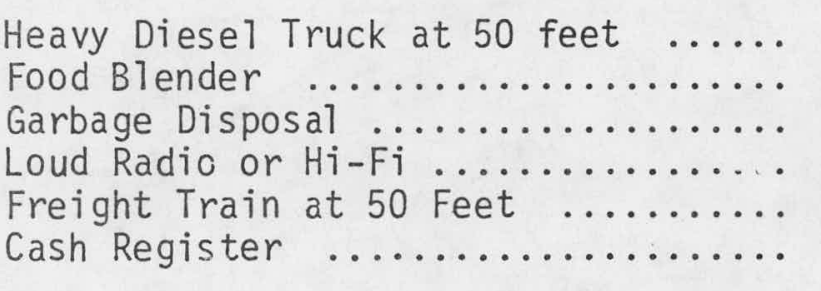 & $\begin{array}{l}90 \\
90 \\
90 \\
80 \\
80 \\
70\end{array}$ & $\begin{array}{l}\text { Very Annoying } \\
\text { Complaining Possible }\end{array}$ \\
\hline $\begin{array}{l}\text { Typical Large Store } \ldots \ldots \ldots \ldots \ldots \ldots \\
\text { Automobile (Average) } 35-40 \text { m.p.h....... } \\
\text { Air Conditioning Unit at } 20 \text { feet } \ldots \ldots \\
\text { Residence } \\
\text { Quiet Conference Room } \ldots \ldots \ldots \ldots \ldots \ldots\end{array}$ & $\begin{array}{l}60 \\
60 \\
60 \\
50\end{array}$ & $\begin{array}{l}\text { Acceptance } \\
\text { Quiet }\end{array}$ \\
\hline Living Room $\ldots$ & 40 & \\
\hline $\begin{array}{l}\text { Bedroom } \\
\text { Whisper at } 5 \text { feet } \ldots \ldots \ldots \ldots \ldots \ldots \ldots \\
\text { Whan. }\end{array}$ & $\begin{array}{l}30 \\
30\end{array}$ & Very Quiet \\
\hline \multirow[t]{2}{*}{$\begin{array}{l}\text { Rustling of Leaves, Broadcast } \\
\text { Studio } \ldots . \ldots \ldots \ldots \ldots \ldots \ldots . . .\end{array}$} & 20 & \\
\hline & 10 & Just Audible \\
\hline Faintest Possible Sound ............. & 0 & $\begin{array}{l}\text { Threshold of } \\
\text { Hearing }\end{array}$ \\
\hline
\end{tabular}

SOURCE: Howard Needles Tammen \& Bergendoff, 1973 


\subsection{Economics}

The proposed site of this project is within the Central Business District of New Orleans, an area which is densely constructed and boasts such valuable properties as the Louisiana Superdome, the Civic Center Complex, the Central Post Office and many other office buildings, hotels and commercial property. Even closer to the proposed construction site is the Louisiana Medical Complex, with many medical offices and other supportive facilities. (The reader is referred to Exhibit 2 for a map of the demonstration community.)

It is anticipated that economic growth in the area without the project would consist primarily of the slow but steady expansion of the existing medical complex (including teaching facilities, hospital beds, support facilities, private offices and parking facilities) and commercial expansion (hotels, etc.) along. Poydras in connection with the Superdome. Other independent facilities, such as apartments, offices, additional government buildings and general parking facilities should also be anticipated.

There are no historic buildings in the project area that would prevent economic expansion in any way. 


\subsection{Future Environmental Conditions of the Project Area Without The}

\section{Proposed Project}

The U.S.E.P.A. and pertinent agencies within the State of Louisiana have established extensive monitoring programs to identify and improve existing problem conditions with respect to air and water quality within the state and therefore, of course, locally. To this end, no major violations of state statutes would be tolerated, and it is not expected that the environmental conditions of the proposed project site would be allowed to deteriorate significantly. Any other proposed facilities which might contribute unfavorably to the environmental quality would also be required to meet performance standards for new sources and therefore not cause significant degradation of the environment.

Increased traffic volume in the area would probably be the biggest environmental concern, especially since New Orleans already has a problem with photochemical oxidants. However, emissions standards for automobiles and other vehicles are continually becoming more stringent. 


\subsection{Federal Agencies}

There are no official Federal land use plans for the project area.

\subsection{State Agencies}

There are no official State land use plans for the project area. The sponsoring agent for this project, HEAL, is an agency of the State of Louisiana and as such, will coordinate all plans with other state bodies.

\section{$3.03 \quad$ Local Agencies}

Other than land use plans of the City of New Orleans, City Planning Commission mentioned below in SECTION $4.02(\mathrm{~g})$, there are no official land use plans by local agencies for the project area. The project is in conformity with plans of the City Planning Commission. 


\subsection{Nature of Impacts - General}

The nature of the primary impacts on the environment by the proposed ICES project is in two general areas: the immediate geographical area of the HEAL project and the remote area where any solid waste is to be disposed. The primary effects in the immediate vicinity of the HEAL site are potential changes in air quality, noise levels, traffic conditions, and esthetic quality.

There will be secondary impacts, both positive and adverse, due to this ICES project. On the positive side, the ma in purpose of the ICES project is to demonstrate an energy-beneficial system of fuel utilization. The success of this project will have a beneficial affect nationally and internationally as a result of the fuel efficiency and multiple fuel capability demonstration. Adverse impacts may result when non-natural gas fossil fuels are used. The mining of coal and the transportation of coal or oil can have undesired effects on areas only remotely related to this project.

\subsection{Beneficial and Adverse Impacts}

\section{Positive Effects}

Within the HEAL area there is the possibility for some specific area to have positive environmental response to the ICES project. The operation of existing, dispersed boiler and chilled water units will be discontinued. In the vicinity of these existing units there will be a reduction of noise and air pollution. Some of these existing units have shorter flue gas stacks than the proposed ICES stack, so the ground-level concentration of certain air pollutants may decrease within the HEAL area. This is undoubtedly true for the case when natural gas is firing the ICES boilers. When other fuels are being used, it will be necessary to perform quantitative dispersion modelling for the area to effectively describe the increase or decrease in air quality. 1

\section{Adverse Effects}

In the following paragraphs the various environmental attributes are described which potentiaily may be adversly affected by this ICES project. Technology can provide solutions to most of these problems as is discussed in the various sections.

a) Noise

In terms of noise, there are noise-control technologies available that can entirely contain the noise of the boilers, turbines, compressors and generators of the ICES plant within the ICES building. The cooling tower fans will be a source of noise but they will be baffled to el iminate any downward-directed noise, that is, to the street. The cooling tower noise will be noticeable to any adjacent area building occupants who are higher than the cooling towers. There are now no such people. That is, there are now not any offices in the area that overlook the cooling towers for the proposed ICES plant. The New Orleans City Hall is in the vicinity, but, at the level of the ICES cooling towers, the end of the City Hall toward the ICES plant (the north end) now consists of machinery rooms for utilities in the building. An addition to the VA Hospital is presently being planned (Bldg. 18 - Exhibit 1), however, details are not known at the present time. Final design of cooling towers will take this expansion into account with respect to noise control features. 
A survey of existing noise levels in the area can be used to quantitatively determine the spatial and temporal distribution of noise in the area. With this information, the design of the noise control equipment for the ICES plant can be specified. The technology exists today in wall construction and opening design to be able to effectively eliminate all noise emissions from the ICES plant's boilers, turbines, compressors, and generators. The new ICES plant will be better designed for noise attenuation than the existing plants and will not be located as close to concentrations of human traffic. Thus the new plant will not cause a deterioration of the noise environment in the medical complex. The noise survey will sample and record, for a 24 hour period, the noise levels at points in the vicinity of the site of the ICES plant. The results of the survey will be required for the design of the noise control system.

b) Air

The operation of this proposed multi-fuel ICES project could have an impact on the clean air environment. However, this impact can be kept to a minimum, producing an inconsequential effect on air quality in the area. The potential pollutants of concern are particulates, sulfur oxides and nitrogen oxides.

Other air pollutants such as hydrocarbons and carbon monoxide are virtually non-existent in properly operating furnaces of the type to be installed here. When fuel oil is being used, the storage and loading facilities will be proferly vented to control hydrocarbon

vapor emissions. There will be no hazardous toxicants associated with this project. The only potential odor emanating from this ICES plant will be sulfur dioxide; control of this species is discussed below. Photochemical oxidants are not primary air pollutants; that is, they are not released from any common pollutant emission source but rather are a result of chemical reactions occurring in the atmosphere due to solar radiation interacting with nitrogen oxides and hydrocarbons.

Particulates and sulfur oxides are a direct result of ash and sulfur content in the fuel, respectively. During periods of operation with firing of a fuel containing sulfur, or that which leaves a residue of ash, the appropriate emission controls must be in effect.

Nitrogen oxides are, on the other hand, generated by combustion of fuels of any type due to the nature of the reactions between the nitrogen and oxygen present in the air in the high temperature regions of the boiler. Nevertheless, there are control techniques in design of the burners and the furnaces that will minimize the generation of nitrogen oxides and keep the emissions well within the regulations of the U. S. Environmental Protection Agency for stationary combustion sources. The U. S. E.P.A. regulations call for new source emissions not to exceed $0.7 \mathrm{lb}$. of $\mathrm{NO}_{x}$ (measured as $\mathrm{NO}_{2}$ ) per million Btu of heat imput when using coal. The new source emissions must not exceed $0.3 \mathrm{lb}$. of $\mathrm{NO}_{x}$ per million Btu on $0 \mathrm{il}$ or $0.2 \mathrm{lb}$. of $\mathrm{NO}$ per million Btu on naturat gas. Assuming these values for the emisssion factors, the annual $\mathrm{NO}_{\mathrm{x}}$ emissions from this ICES plant will be 503 tons with coal firing, 216 tons with oil, and 144 tons with natural gas.

The Louisiana Air Control Commission regulations require that $\mathrm{NO}_{\mathrm{x}}$ emissions be low enough so that they do not violate the ambient air quality standards as evidenced by dispersion modelling for new plants. The 
nitrogen oxide emissions from this ICES plant are expected to be well below the levels required by the Louisiana Air Control Commission. This modelling will be competed as required prior to permit application.

Particulate emissions from the combustion process can be controlled with available technology. Th U. S. E.P.A. performance standard for this ICES plant will be 0.1 pound of particulate per million Btu heat input in the fuel for fossil fuels; the performance on processed refuse will be taken to be the same. With natural gas of fuel oil firing, particulates are not present. The particulate emissions which would result from coal combustion if there were no control equipment would be in excess of the E.P.A. standard. For a coal with $7 \%$ ash, the emission rate would be 5.8 pounds of particulates per million Btu. This is an annual rate for the ICES plant of 4200 tons of particulates. This "potential emissions" rate is used by E.P.A. to determine if the new plant is, in its terminology, a "major stationary source." The ICES plant does fall under E.P.A. regulations as a major stationary source. The true annual emission rate from the ICES will be 72 tons of particulates with the control equipment as designed. The particulate collection equipment will consist of two collectors in series. A wet scrubber will be installed which simultaneously removes particulates and $\mathrm{SO}_{2}$ (see below) along with a high-efficiency cyclone placed ahead of the scrubber to remove the bulk of the particulates. The overall collection efficiencies of these two units are $90 \%$ and $85 \%$, respectively. The two particulate collectors will recover 3600 tons (for the cyclone) and 600 tons (for the scrubber) annually from the flue gases when coal is being fired. The cyclone collectate will be dry and will be disposed of in a landfill (see below); the scrubber collectate will be in water slurry and will be discharged to settling ponds.

The Federal Prevention of Significant air quality Deterioration (PSD) requirements possibly are more strict than the "performance standards" mentioned above. The PSD requires that the increase in total suspended particulates (TSP) concentration in the ambient air not exceed the allowable "increment". Atmospheric dispersion modelling is required to determine what the effect of the particulate emissions from this ICES will have on the ambient air TSP, but in any event, appropriate particulate control devices can be installed to meet whatever requirement is most strict.

The PSD requirements call for a review including an analysis of air quality and impact of a new source based on modelling. This review is not applicable to nonprofit health or educational institutions such as the HEAL project. However, due to the fact that NOPSI (a profit-making company) is to be the operator of the facility, the PSD review might be required. Preparation for such a review of this project will be made in the event it is conducted.

Spurious emissions of dust from loading and unloading of collected fly-ash and solid fuel will be eliminated by having all such operations conducted indoors. Proper operating procedures for these loading operations and filtered ventilation of the loading area will control all dust emissions. The trucks will be covered or the coal and ash will be properly coated so that no dust emissions will result from wind-carry from the trucks.

Sulfur oxides will be within the emission limitations of the Louisiana Air Control Commission for the fuels thus far identified. The 1 imit on sulfur $\left(\mathrm{SO}_{2}\right)$ emissions is $1.21 \mathrm{~b}$. of $\mathrm{SO}_{2}$ per million $\mathrm{Btu}$ heat input in the fuel. One of the coals identified (the Oklahoma coal) would result in $0.841 \mathrm{~b} . \mathrm{SO}_{2}$ per million $\mathrm{Btu}$ and 
the other coal (the Kentucky coal) would result in $1.161 \mathrm{~b}$. or less $\mathrm{SO}_{2}$ per million Btu. These calculations are based on a $97 \%$ conversion of fuel-sulfur to $\mathrm{SO}_{2}$ emissions for a stoker furnace designed for the HEAL ICES project. This conversion fraction was reported as the actual observed conversion in tests on stoker furnaces with bituminous coals. (second symposium on Stationary Source Combustions, August 1977, New Orleans, La., sponsored by the U.S. E.P.A.). The annual emission rate of sulfur oxides if the higher-sulfur coal were to be used exclusively would be 860 tons.

The possibility exists that the U.S. Environmental Protection Agency will promulgate more stringent standards on $\mathrm{SO}_{2}$ emissions than those mentioned above. As allowed for in the Clean Air Act Amendments of 1977 (PL95-95) the Administrator (of EPA) may require some percentage reduction of sulfur emissions from a stationary source, irrespective of the natural level resulting from the fuelsulfur conversion. This effectively eliminates the existence of "compliance coal" as we have identified. (Newly proposed EPA emission standards on the performance of new sources such as this ICES are to be published shortly after this report was prepared. They are expected to call for $90 \%$ removal of $\mathrm{SO}_{2}$ from the flue gases. This would indicate the first or second alternative listed below). Upon promulgation of this requirement, there are several alternatives for the HEAL ICES project. One alternative is to not use a sulfurcontaining fuel. This would el iminate coal and much oil from consideration. A second alternative is to implement the flue gas desulfurization capabilities of the wet scrubber. By adding sodium hydroxide ( $\mathrm{NaOH}$ ) or sodium carbonate $\left(\mathrm{Na}_{2} \mathrm{CO}_{3}\right)$ to the scrubber 7 iquor it will entrap the sulfur oxides as sodium bisulfate $\left(\mathrm{NaHSO}_{4}\right)$. The scrubber design used in the ICES plant is capable of removing from 90 to $95 \%$ of the sulfur oxides, depending upon the concentration of the liquor. The scrubbing liquor is sent to a hydroclone and a settling vessel where the solids are removed. Sodium-based scrubber liquors are preferred to 1 ime-based scrubber liquors for this size application due to the absence of scaling and sludge disposal problems that plague the 1 ime-based systems. A third alternative is to inject lime or limestone into the furnace and allow the lime to capture the $\mathrm{SO}_{2}$ (as calcium sulfate) which can then be collected in the particulate collection devices and disposed of with the collected ash. There is presently scanty data available on the efficiency of this alternative. A fourth alternative is to purchase a "washed" coal. Cleaning of coal to remove a portion of the ash and the sulfur is an available technology and this method of sulfur reduction is allowed in the Clean Air Act Amendments of 1977 .

The Federal PSD requirements apply for $\mathrm{SO}_{2}$ as for TSP described above. These requirements and the requirements applicable for using the best available control technology will be met.

c) Water

A11 necessary pretreatment of water wastes from the ICES will be contained within the design of the plant. The rules for allowable discharges of the Sewerage and Water Board (S\&WB) of New Orleans will be met in toto. The wastes from the ICES will consist of boiler water blow down, wastes from the regeneration of the boiler feedwater demineralizer and cooling tower water blow down. These water wastes will be present irrespective of which fuel is used in the ICES project and these water wastes are now present in the dispersed steam and chilled water plants in the HEAL complex. 
The wet scrubber will have a bleed stream that contains the particulates and sodium bi-sulfate that it removes from the flue gas. The rules of the New Orleans Sewerage and Water board specifically allow "industrial waste" such as these to be admitted to the storm drainage system provided, of course, that all pollutants are within certain limits. This limitation is to control the pollution in the receiving water which ultimately receives the storm drainage water. The appropriate limitations for the ICES plant are (as taken from Section 16.1, "Rules Governing Discharges into the Public Storm Drainage System", of the New Orleans Sewerage \& Water Board):

(3) The wastes do not contain suspended solids in excess of 42 pounds per day at a maximum concentration of $25 \mathrm{mg} / 1$.

(6) The wastes do not cause an objectional change in the $\mathrm{pH}$ of the waters contained in the drainage system.

(8) The wastes do not exceed 110 degrees Fahrenheit or raise the temperature of the receiving canal by more than five degrees Fahrenheit.

(14) The wastes do not contain unusual concentrations of total dissolved solids (such as sodium chloride or sodium sulfate).

Pretreatment of the liquid wastes in the ICES project will be necessary prior to discharge into the public storm drainage system. The New Orleans Sewerage \& Water Board specifically allows pretreatment (other than simple dilution) to attain the limits for allowable discharge. Specifications for any pretreatment processes will be submitted to and permits obtained from the New Orleans Sewerage \& Water Board prior to the start of construction. An alternative to release of water wastes into the storm drainage system is to have the wastes trucked away to a settling pond. Quite possibly a combination of these two alternatives will be determined to be the optimum; that is, discharges into the storm sewer will be limited to the allowable levels and any remaining wastes will be removed by tank trucks to a disposal site.

The treatment of all wastes in the ICES plant will be done in neutralization tanks and holding tanks to meet all S\&WB discharge requirements.

\section{d) Solid Waste}

Plant operations will require a procedure for solid waste disposal during periods of operation when an ash-containing fuel is used. The piant operator will contract for ash removal for landfill in Orleans Parish (of which there are several at the present time) or for a feed material for manufacturing, say, of concrete blocks. The quantity of ash that would be produced each year if coal were used exclusively as the fuel would be about 4000 tons ( 4000 cubic yards) for the 0klahoma coal and about 2000 tons (2000 cubic yards) for the Kentucky coal. Either of these quantities would pose no disposal problems to the contractor. This solid waste is predominately alumina and silica and will have no contaminating effect on the 1 andfill. 
e) Esthetic Values

The project will have impacts on the visual esthetic values in the area in two ways. First, the plant and stack will alter the cityscape in the area. These, however, will be architecturally designed to enhance the area and the smokestack design will be, in keeping with clean air requirements, kept to a minimum height. An elevation drawing of the preliminary design is included as Exhibit 6.

Secondly, the transport of the steam and chilled water distribution piping on an elevated structure will have a visual impact on the area. In an effort to mitigate this effect, the proposed overhead distribution system will be located such that it can later be assimilated into the proposed future overhead covered wal kway system proposed both by the City Planning Commission and HEAL. The walkway system, as proposed by the city, would connect the Superdome with Tulane Ave. and possibly even Canal St. The HEAL system would be an overhead covered walkway connecting essentially all major buildings in the HEAL complex. The proposed layout, shown as Exhibit 7, anticipates the routing of these walkway systems. The appearance of these structures will be in keeping with existing overhead walkways in the area. Architecturally they will be designed in such a manner that the visual impacts on the area will be kept to a minimum. In addition, as an added benefit, the overhead system will provide some shade and protection for parked cars and sidewalk pedestrians. Descriptive drawings of the preliminary walkway designs are shown as Exhibits 8, 9 and 10. 


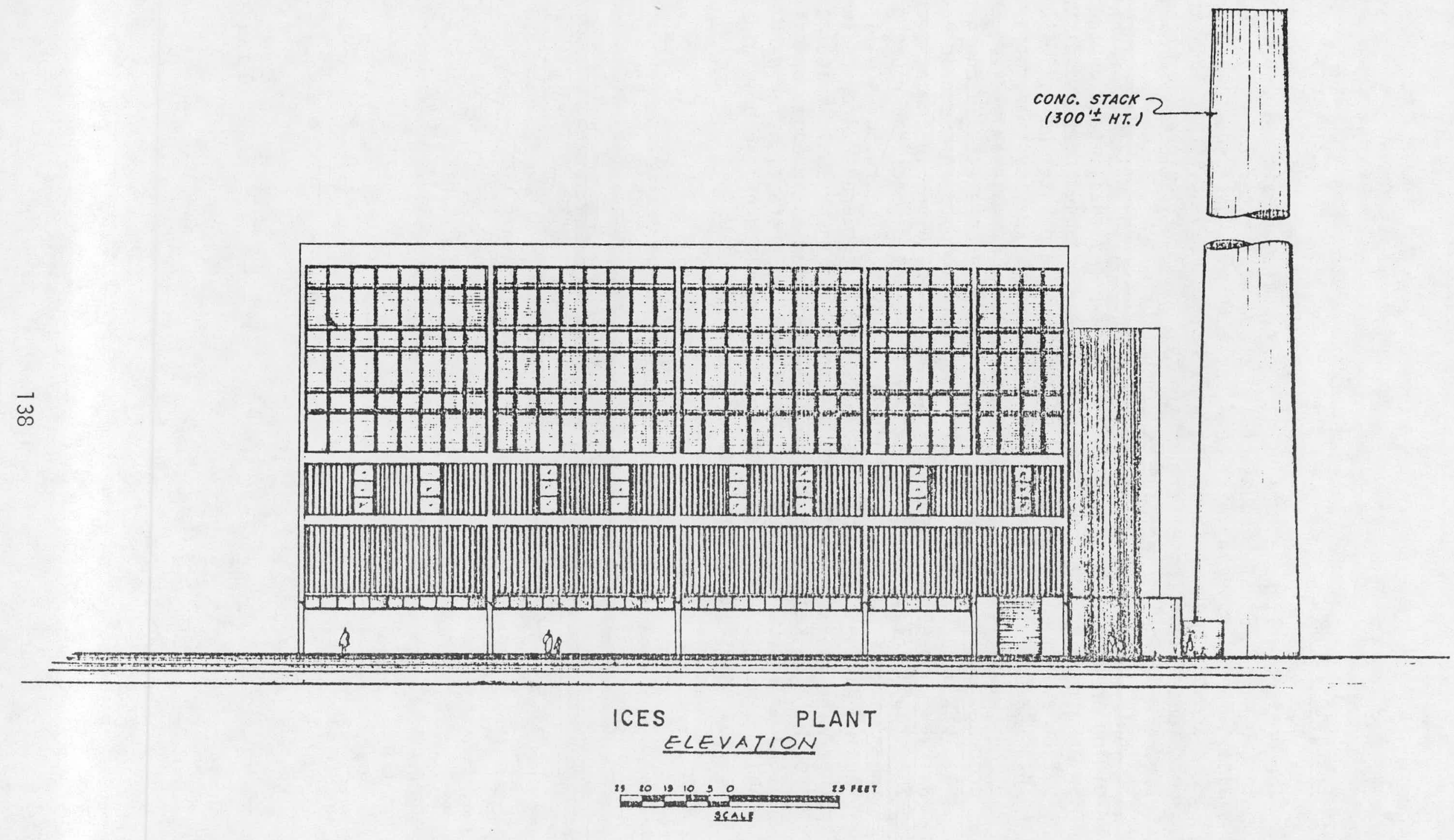




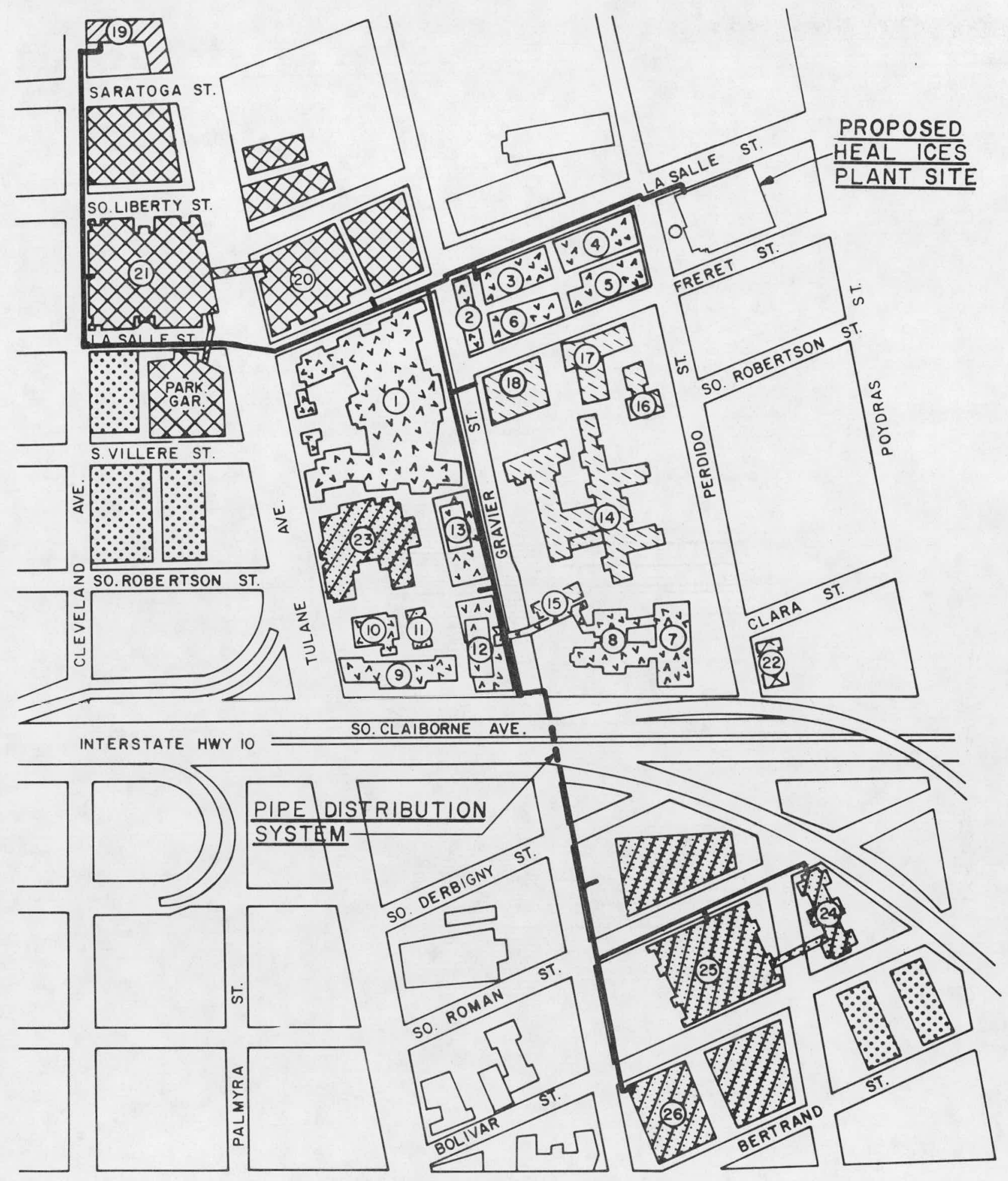

DEMONSTRATION COMMUNITY

[E. CHARITY HOSPITAL

EYE,EAR, NOSE \& THROAT HOSP.

VVETERANS ADMIN.

LSU MED. CENTER

Q tulane med. Center

$\therefore$ HEAL

CHILLED WATER \& STEAM

DISTRIBUTION SYSTEM LAYOUT

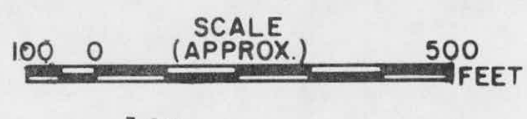




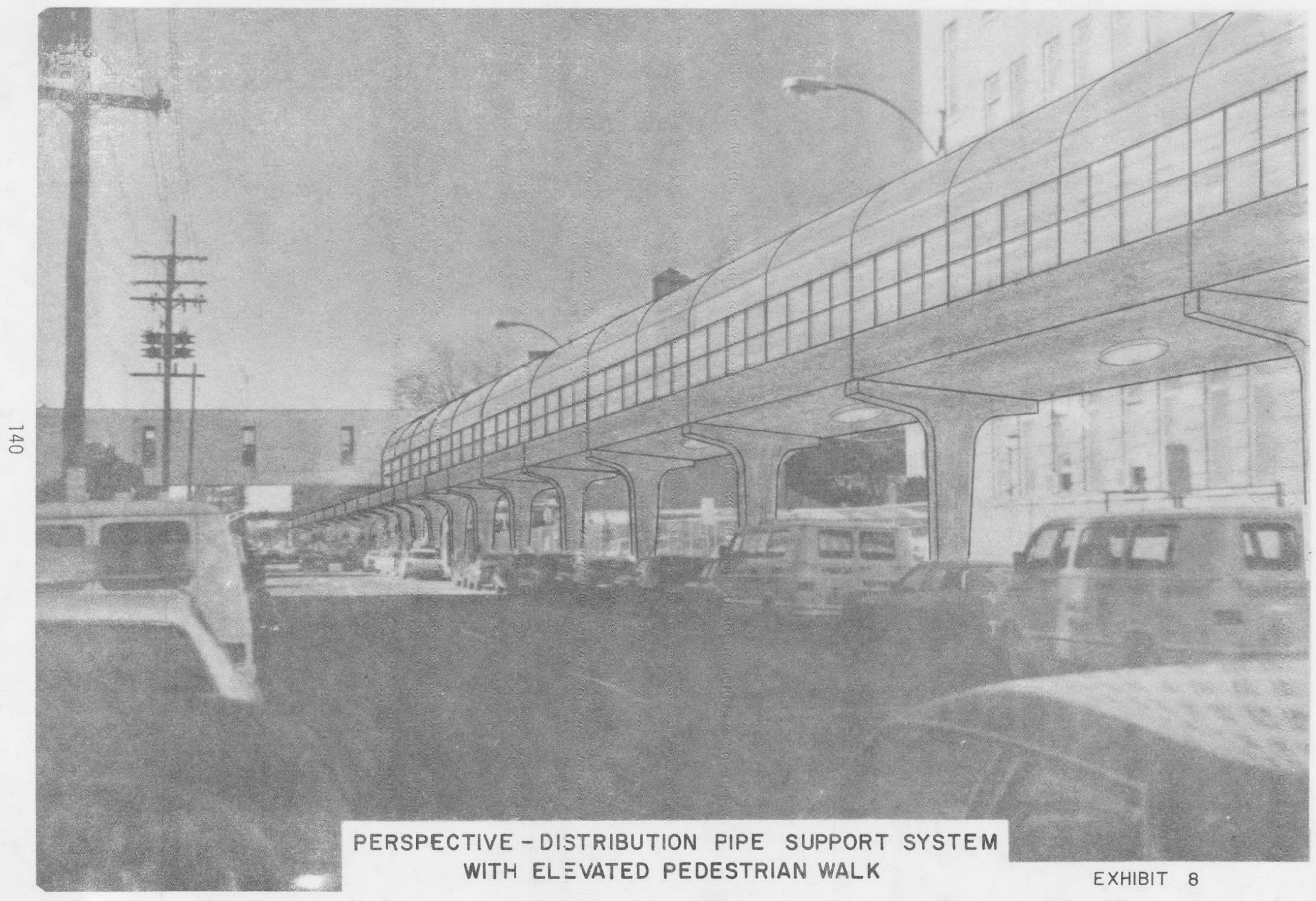




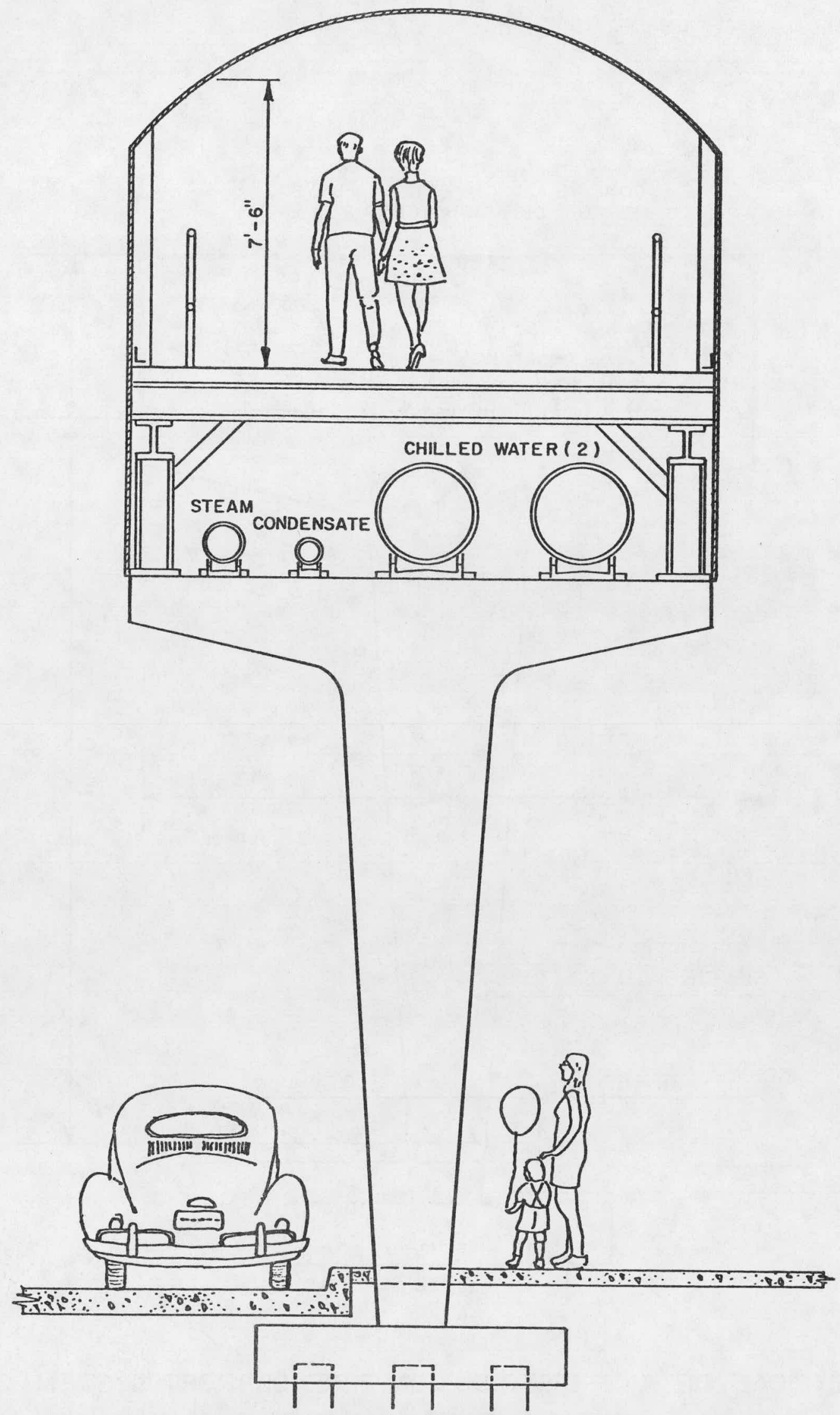

TYPICAL DETAIL - DISTRIBUTION PIPE SUPPORT SYSTEM MODIFIED FOR ELEVATED PEDESTRIAN WALK

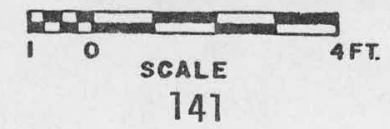

EXHIBIT 9 


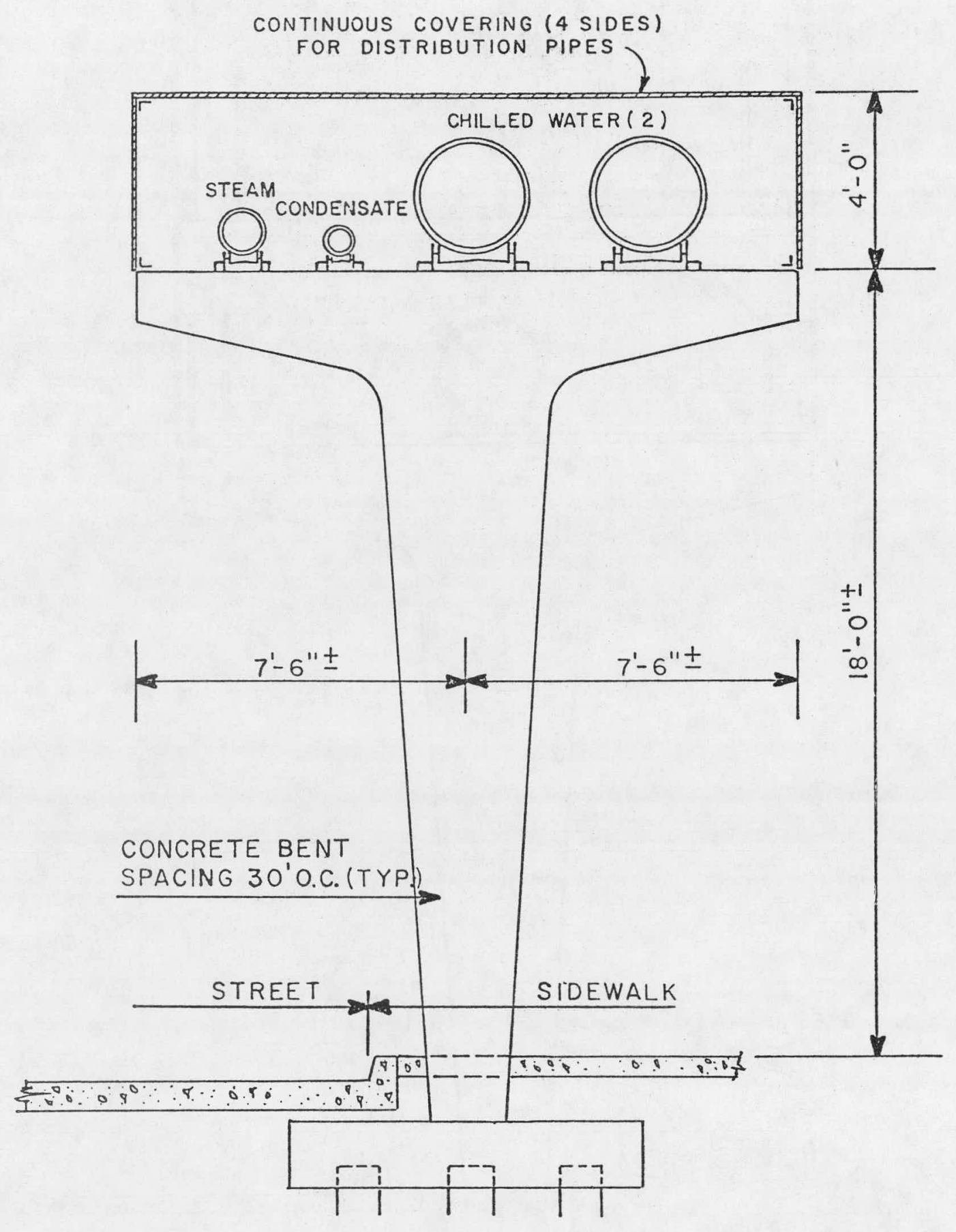

TYPICAL DETAIL - DISTRIBUTION PIPE SUPPORT SYSTEM INITIAL CONSTRUCTION

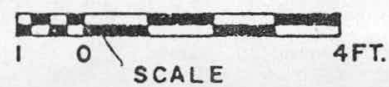


The project site is located on the perimeter of the Central Business District and borders on Poydras St., a six-lane thoroughfare leading into the CBD. Existing transportation to and from the site both for autos and trucks is excellent, as Poydras St. is an existing truck route. Transit services to the site are also excellent. The latest city traffic count on Poydras Street (at LaSalle St.) is approximately 13,000 vehicles each way over a 24 hour period. Based on the city's estimate of a mix of $5 \%-8 \%$ trucks, it is estimated that approximately 1300 to 2080 trucks pass the site daily.

The proposed method of transporting fuel to the plant, when coal or fuel oil is used, will be by trailer trucks. It is estimated that fewer than 15 trucks per day will be required for delivery. In addition, one truck per day will be required to remove ash. This volume of truck traffic, during operations, will not significantly impact the existing transportation network. It is also not anticipated that the operation of the plant will attract additional daily workers or visitors to the area and therefore, no additional burdens will be placed on the existing transit or street systems.

\section{g) Land Use and Zoning}

Land uses must conform to requirements of the City of New Orleans City Planning Commission and the Comprehensive Zoning Ordinance for the City of ilew Orleans. The project is located in the New Orleans Central Business District and falls within the area classified as CBD-2. This is an area designated to provide for central business district growth at lower intensities than the main office core. Within this district, hospitals and their related support facilities are a permitted use.

The proposed site is now used partially as an at-grade parking lot. A warehouse now occupies the other portion of the site. This building will be demolished as part of the project.

Land uses adjacent to the site include an at-grade parking area, the Charity Hospital Power Plant and Maintenance Bldg., City Hall and City Hall Parking Building, and across Poydras St. is the Louisiana Superdome. The general area is occupied by Government buildings, the HEAL Medical Complex and a few small industrial or warehouse buildings.

It has been anticipated by the City Planning Commission that the property facing the Superdome along Poydras St. should be utilized as high use commercial grade property. In addition to this commercial use, land use preferences for the area include high density residential and office buildings, light industrial complexes and further expansion of the existing medical facilities. Existing zoning also allows for the construction of overhead covered walkways.

\section{Project Impacts}

The power plant building is to be located on a partially empty parking lot and will minimize demolition. To be demolished will be a warehouse of no architectural or historic significance. Also, no people will be displaced due to demolition. The property will be purchased outright at fair market prices. As shown on Exhibit 11, the power plant layout will leave a 30,000 square foot 


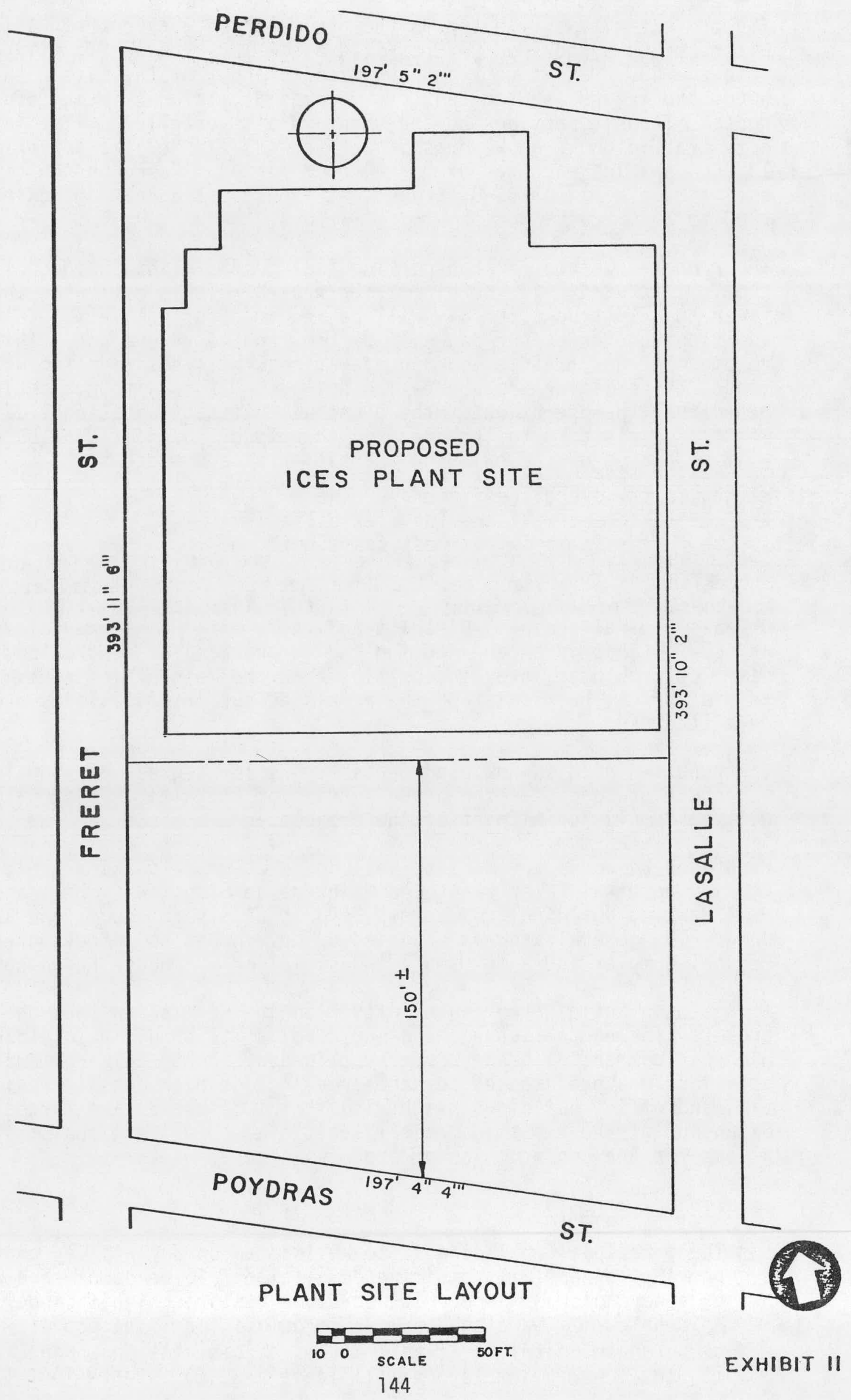


piece of property with approximately 200 feet fronting along Poydras St. for future development as a commercial venture, in keeping with land use plans for the area.

The overhead pipe distribution system will be constructed near the street curb on city owned right-of-way. It is anticipated that no problems will be incurred in obtaining approval from the city for this construction. As stated earlier, it is proposed to coordinate this construction with future city and HEAL plans to construct an overhead walkway system in the area.

A11 construction planned for this project is in conformance with land use plans and zoning restrictions for the area.

h) Energy

Centralization of thermal utilities in one plant will eliminate from the individual medical institution buildings the present burning of gas in their steam boiler plants. Such consolidation will result in a more efficient operation, thereby reducing the level of total fuel consumption. The byproduct generation of electricity in this plant also will contribute significantly to the overall efficiency. The multiple-fuel capability of the central plant will provide flexibility in the matter of fuel selection, a feature that is, in most cases, not available to the institutions individually.

The energy requirements for the operation of the air and water pollution control equipment cannot be quantitatively determined at this time, but it will be small compared to the energy (fuel) savings resulting from the high-efficiency conversion process of the ICES. Accurate estimates of the energy consumption of the pollution control schemes can be made when the designs are more firm. These will be reported in the final version of this assessment. Energy will be consumed in the obvious areas of trucking away solid and liquid wastes, and also in the energy required to overcome the pressure drops in the flue gas cyclone and wet scrubber.

i) Fire Prevention

The HEAL ICES plant will be constructed in accordance with all city, state and federal regulations concerning fire codes. The plant site is easily accessible to fire fighting equipment in the event of a fire. The overhead pipe distribution structure will not present any fire hazard in itself. Any leakage of hot condensate, steam or cold water will be contained within the structure and drained through pipes into the street drainage system. This structure, however, might offer some hindrance to fire fighting equipment in the event of a fire adjacent to the structure. Special attention will be given to this potential problem during design in order to alleviate any possibility of reduction of fire protection in the area.

\section{j) Construction}

Some minor impacts on the environment during the construction phase are unavoidable. These include impacts on air quality, noise, water quality, waste disposal, transportation, energy usage, economy, material supplies, and ecology. Some minor adverse impacts on existing air quality, noise level, water quality, waste disposal, transportation and energy dissipation are expected on any construction project, 
however, with the use of normal care and following the various regulations governing construction in the area, these will be kept to a minimum. The effects on material supplies should also be minor as few of the construction materials are considered in short supply. The impacts on the community will be beneficial as concerns the economy, as the city has a high unemployment rate and the construction will provide additional jobs. The site location, being in the Central Business District, is not considered a fragile ecological system and thus no adverse impacts are seen in this area.

\subsection{3}

Secondary Impacts

There will be secondary impacts due to this ICES plant operation arising out of its use of non-gaseous fossil fuels and any potential waste disposal. When coal is being used there will be the impacts upon the areas where the mining of the coal takes place. These effects include land disturbance, solid waste disposal, employment demand changes, and acid mine drainage. When oil is being used there will be impacts due to the extraction of the oil potentially including drilling, spillage and brine disposal. In either event there will be changes in fuel transportation methods that will affect highways and/or waterways between the location of fuel extraction and the ICES plant.

The solids waste disposal (both dry and slurried) will have a secondary effect in their disposal areas. The increase in landfill will make available for development some previously unusable land with its accompanying economic and human effects. Any suspended solids in the storm drainage system may affect commercial or recreational aquatic harvesting in Lake Pontchartrain. It is assumed that the New Orleans Sewerage \& Water Board regulations are sufficient to minimize this last effect. 
The only adverse environmental effects other than those due to construction which do not seem to be reasonably avoidable are the aesthetic impacts of the elevated pipeways for the transport of the steam and chilled water. The impact of these can be mitigated to some extent by proper design that can be determined to be as attractive and unobtrusive as possible. Where the elevated pipeways coincide with pedestrian walkways, their impact will be minimal.

Table IX is included as an overall numerical evaluation of the total environmental impacts of the proposed. ICES project. 
TABLE IX

INDEX EVALUATION OF THE IMPACTS OF THE HEAL ICES PLANT

Areas of Consideration

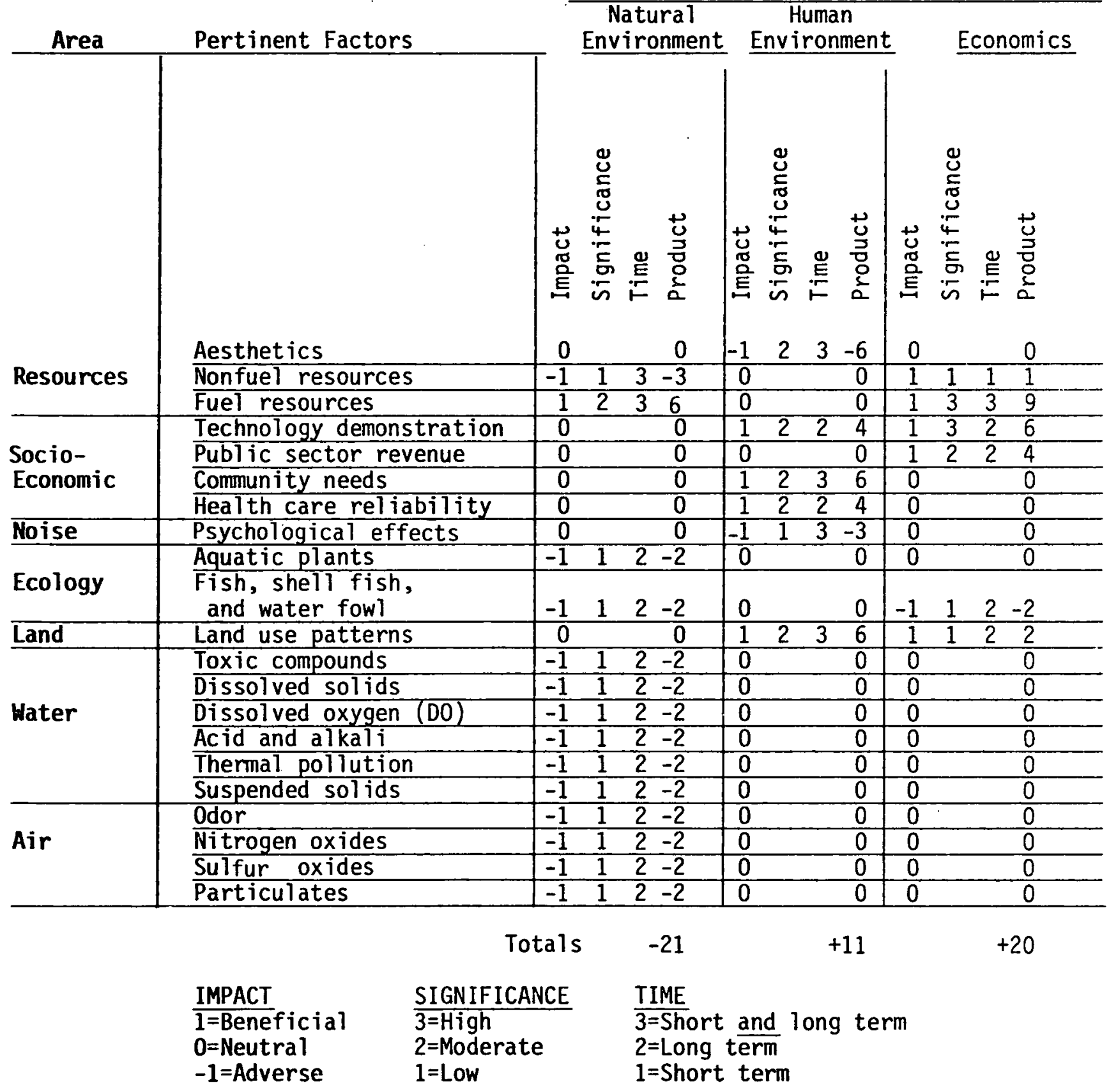


Reasonable Alternative Actions

In general there is but one major alternative to the proposed HEAL ICES project it is to do nothing; that is, to maintain the present systems of steam and chilled water generation in each of the HEAL facilities. This would of course aggravate the future problems of energy cost and fuel availability that are addressed by the proposed ICES project. The participating institutions must consider the prospect of closing some of their facilities during periods of natural gas shortages that may occur during the next decade.

An alternative which would el iminate this last problem would be for each present user to go to multiple fuel capability. This is considered to be an impractical alternative for most of the institutions, especially with respect to fuel oil or solid fuels, particularly with regard to storage and handling problems.

An alternative which would eliminate the aesthetic impact of the elevated pipeways (discussed in Section 5) would be to place the pipes underground. There are two difficulties with this, first the greater expense and disruption during construction and second, the presence of the many existing pipes and conduits in this area make the routing extremely difficult.

Another alternative is for the HEAL complex to go to an all-electric energy system. This is unfavorable largely from an energy-conservation point of view; operating costs may be higher and the impact on clean air and water would be similar to or worse than those from the ICES project. Other environmental impacts would probably be less. 
SECTION 7 -- THE RELATIONSHIP BETWEEN LOCAL SHORT-TERM USES OF MAN'S ENVIRONMENT AND THE MAINTENANCE AND ENHANCEMENT OF LONGTERM PRODUCTIVITY

The relationship between local short-term uses of man's environment and the maintenance and enhancement of long-term productivity is often one of trade offs and balancing of impacts. In the case of this project, this is possibly the most important point to be made, as the primary benefit to be gained is a longterm benefit concerning more efficient use of energy resources.

The adverse short-term uses of the local environment which are necessary to obtain the long-term productivity desired in this project are as follows:

1. Construction impacts, which include increases in noise, decreases in air and water quality and the temporary limited disruption of area activities.

2. Elimination of possible city or state tax revenues due to use of land for non-profit, therefore non-taxable, purposes instead of reserving the land for a private, taxable venture.

The basic long-term benefits (productivity), to be gained by proceeding with the HEAL ICES project are as follows:

1. The project will provide for more efficient use of fuel for energy production and therefore will provide for much needed conservation of energy sources.

2. One of the more important long-term benefit resulting from this project will be the information gathered by the Deptartment of Energy as a result of the demonstration aspect of the project. This information will be distributed nationally for the future benefit of the entire country.

3. There will be an improved potential for further expansion of the existing medical facilities in the area.

4. The project provides HFAL with an economical method of dealing with future energy problems, in particular, the possible future high cost, scarcity, or outright elimination of availability of natural gas, the fuel now presently being used by the institutions.

Other long-term impacts that are seen to balance out over the long term are as follows:

1. It is anticipated that the initial capital costs funded by the issuance of 30-year bonds will be easily covered by revenues derived from the efficient and economical production of energy in the HEAL ICES plant.

2. Associated with the construction of the overhead pipe distribution system are certain possible visual and fire protection impacts. These, however, may be mitigated by the construction of a safe, protected overhead communication system for the entire medical complex as indicated on the enclosed exhibits. 
SECTION 8 -- IRREVERSIBLE AND IRRETRIEVABLE COMMITMENT OF RESOURCES WHICH WOULD BE INVOLVED SHOULD THE HEAL ICES PROJECT BE INSTITUTED

The HEAL ICES plant is in an area that is a highly urban, moderately congested hospital and supportive business district. The change to the area in terms of loss of land resources and the like will be minimal. Certain physical resources needed to construct the plant will, of course, be virtually irretriev-

able. Materials in this category include the steel, concrete, wood, and other metals for the equipment. None of these materials are in shortage today in any: practical sense, and thus their use cannot be considered a significant environmental assault. This project will require initial financial and energy consumption which can be recouped, and more, by the savings which.will accrue over the life of the ICES plant. In fact, implementation of this ICES project will cause less commitment of energy resources over its 1 ife than the combined present dispersed steam and chilled water plants in the various institutions. This project will similarly in the short term (engineering and construction) require an irretrievable commitment of labor. Again, as with monies and energy, over the life of the plant, there will possibly be a negative labor balance; that is, the total labor hours for the ICES will compare favorably with the total for the present separated plants. This is due to the lower labor requirement per unit of plant productivity of the integrated system as opposed to the discrete separated plants.

In terms of specific irretrievable commitment of coal resources (assuming an eventually predominate coal usage), the current greatest utility is gained from coal by combustion (as compared to, for example, chemical feedstock uses), and the use of coal in a high-energy-conversion system such as this ICES yields the greatest utility per unit of coal of any current technology of energy conversion. 
SECTION 9 -- OTHER CONSIDERATIONS THAT OFFSET THE POTENTIALLY ADVERSE ENVIRONMENTAL EFFECTS OF HEAL ICES PROJECT

The grid-connected ICES concept is one which is important to be demonstrated in a configuration such as proposed here. The ICES arrangement allows for the maximum possible energy conversion efficiency from a primary fuel source with available technology. The integration of electrical generation with the supply of steam and chilled water (through compression refrigeration) allows for

the required heating, cooling and electrical consumption of the community with less fuel than if the units were not integrated. This requirement of less fuel is important not only for the economy experienced by the community but it conserves the diminishing supply of our energy resources.

The multi-fuel capability of this ICES design brings another consideration. The ability to utilize a variety of fuels will give the plant operator additional flexibility in fuel procurement which can be used for benefit of economy or source reliability. It is important that the HEAL community have a reliable source of fuel in order to avoid curtailing of services to the region.

The primary alternative to the ICES project proposed here is to maintain the present dispersed energy systems throughout the HEAL community. The benefits mentioned above (economy of fuel and reliability of supply) could not be realized with the present systems.

With respect to economy, with reasonable prices and inflation rates applied to natural gas and coal, for example, the estimated energy savings to liEAL over the period of 1982 to 2000 will be in excess of $\$ 150,000,000$ In the multifuel design, the savings cannot be less, because the alternate fuels may be used on a whenavailable-for-a-lower-price basis. Additionally, the present systems can only use natural gas as fuel. 


\subsection{Public Participation}

Notices of availability of the draft environmental impact statement to the public will be published in appropriate newspapers and by the distribution of a public notice. All relevant and appropriate comments received will be included in the final environmental statement incorporating changes where necessary.

\subsection{Government Agencies}

A copy of this draft environmental statement will be furnished those governmental agencies listed in paragraph 5 of the Summary, requesting their comments. A11 relevant and appropriate comments received will be included in the final environmental statement, incorporating changes where necessary.

10.03 Citizens' Groups

This draft environmental statement will be mailed to those environmental agencies and groups listed in paragraph 5 of the summary and will be made available to the public through news releases in newspapers. 
BIBLIOGRAPHY

A \& WQA Urban and Transportation Associates, City of New Orleans Air and Water Quality Analysis, prepared for the lew Orleans City Planning Commission, June, 1977.

MOISE Noise, H. A., An Emergency Air Episode Plan for the Greater Metropolitan New Orleans Area, unpublished Master's Thesis, Tulane University, Department of Civil Engineering, July, 1970.

MRBA Draft Environmental Impact Statement, Greater New Orleans Mississippi River Bridge No. 2, Mississippi River Bridge Authority, November, 1376 .

154 


\section{TASK III B}

DESIGN ANALYSES, STAGE 2

There are no deliverables in Stage 2 for design analyses.

A1l deliverables for design analyses were assigned to Stage I and appear in Task III as included in the Stage I report. 
PRELIMINARY DESIGN, STAGE 2 


\section{4.b.1 DESIGN DESCRIPTION OF PLANT}

\section{4.b.1.1 General}

The proposed central plant is designed to provide the thermal requirements of the Demonstration Community identified as the HEAL Complex, and the initial design is based upon the plant becoming operational in the year 1982 .

The HEAL Complex master plan was used as a basis for the plant design initially and projected to the year 2000. During the period of 1975 through the year 2000, the space needs of the complex are projected to increase from $3,188,611$ square feet to $7,803,000$ square feet, or approximately 145 percent.

The plant loads also would increase at approximately this same rate. Therefore, the maximum thermal demands on the plant in the year 1982 are 160,890 pounds per hour steam generated and 10,000 tons of refrigeration, the production of which will result in simultaneous generation of approximately $7600 \mathrm{KW}$ of by-product electrical energy. The maximum thermal demands on the plant in the year 2000 are 340,000 pounds per hour steam generated and 21,150 tons of refrigeration, which will produce approximately $14,900 \mathrm{KW}$ of by-product electrical energy.

With these load demands, initially and to year 2000, steam, refrigeration and electrical system growth charts were constructed and from these data equipment sizing was optimized and indicated as to the points in time that plant equipment would be reeded and installed to serve the community - the first plant equipment expansion occurring in 1990-91 and the second expansion, requiring a building addition, occurring in 1997.

Under all load conditions, adequate standby equipment is provided for the thermal loads imposed. The need for electrical generating standby capacity within the plant is not necessary as the interconnections with the New Orleans Public Service grid are considered adequate.

4.b.1.2 Site

The plant site is known as subdivision lot 365 and occupies approximately the northern two-thirds of the lot, which is bounded by Perdido Street on the north, LaSalle Street on the east, Poydras Street on the south, and Freret Street on the west.

\section{4.b.1.3 Utilities}

The utilities required to serve the plant adequately are $12^{\prime \prime}$ 
water, 12" sanitary sewer, and 14" storm sewer. Utilities capable of handling these requirements exist in Poydras Street, and connections will be made to the plant by extending the services from Poydras down Freret Street to the point of entrance to the plant. Initial water requirements are estimated at $1250 \mathrm{gpm}$, with a future of $2500 \mathrm{gpm}$.

Sanitary sewer flow is 6.5 cfs initially, with a future requirement of $12.0 \mathrm{cfs}$. The storm water requirements from the plant are approximately $8.5 \mathrm{cfs}$ present and $14.5 \mathrm{cfs}$ future.

\section{4.b.1.4 Boilers}

The boilers, two at 200,000 pounds per hour initially, will operate at 1250 psig and $950^{\circ} \mathrm{F}$ superheat and will be balanced draft, field erected, arranged for multiple fuel firing including coal, oil, gas and refuse. Initially the equipment will be capable of burning any two fuels simultaneously with the exception of refuse fuel. The combustion control system will be the direct digital control fully automatic type arranged to control the rate of heat release by controlling the fuel air ratio at maximum efficiency. A master steam pressure controller will compare the pressure to the set point and any deviation will cause the master pressure controller to take corrective action to increase or decrease the master loading signal as required. The boilers will be equipped with the necessary fuel burning equipment, forced draft fans and ductwork, in addition to equipment for the exit gas system, as described eisewhere in this report.

\section{4.b.1.5 Coal Handling and Storage}

Coal will be delivered by barge to the New Orleans Public Bulk Terminal located on the Gulf Seaway approximately 8 to 10 miles east of the proposed plant site. At this point the barges will be unloaded, the coal placed in storage, and trucked to the plant as required to maintain the plant storage capacity of about 1750 tons. Initially the plant storage is adequate for 12 to 14 days supply and ultimately for 5 to 7 days supply. It is planned that the main storage at the terminal would be maintained at approximately 15,000 tons and ultimately at 30,000 tons. The inplant coal storage consists of two silos, each capable of 500 tons, and the bunker, capable of 950 tons initially and 1,000 tons ultimately.

The coal will be delivered by 20 -ton end dump trucks and discharged into the truck hopper, then conveyed at the rate of 50 tons per hour through a coal crusher and to the bucket elevator for discharge to either silo or the coal bunker. 
From the bunkers the coal will pass through coal scales and into the stoker feed hoppers.

The coal handling system is so designed that coal can be fed directly from the truck hopper to the boilers as described or the coal can be fed to either silo, or from either silo to the bunker. Provision has also been made to take coal from the bunker and discharge to the elevator and then to either silo or to discharge to a truck for disposal if necessary.

\section{4.b.1.6 Ash Handling and Storage}

Ash will be accumulated in stoker ash pits and sifting hoppers and periodically removed and conveyed pneumatically to an ash receiver and air washer mounted atop the ash storage silo located in the coal truck unloading area directly above the coal truck hopper. In addition to the bottom ash pick up locations, fly ash will also be accumulated in the boiler fly ash hoppers and the fly ash collector hoppers and pneumatically conveyed to the same ash storage silo. The entire ash conveying system will be automatically remotely operated.

\section{4.b.1.7 Flue Gas Emissions Treatment Equipment}

Each boiler will be equipped with a fly ash dust collector which will remove the heavier and major portion of the particulate emissions contained in the flue gas prior to the gas being passed through a feed water economizer where the flue gas temperature will be reduced approximately $100^{\circ} \mathrm{F}$ and the feed water temperature raised to $347^{\circ} \mathrm{F}$. From the economizer outlet the flue gas will pass through a wet scrubber utilizing a sodium carbonate recirculating solution, impingement baffles, etc., where additional particulate matter is removed from the gas stream; and as the gas continues through the scrubber the $\mathrm{SO}_{2}$ gas reacts with the sodium carbonate solution to form sodium sulphite. The gas then flows to the induced draft fan and is discharged to the stack. The solution is recirculated and the waste material settled out through a series of tanks to the clarifier and finally to the waste treatment tanks for ultimate disposal. The scrubber, ductwork, induced draft fan, and breeching to the stack are all constructed of 316 stainless steel and the interior of the stack lined with a chemically inert coating.

\section{4.b.1.8 Boiler Feed Water Makeup Equipment}

The plant will be equipped with a dual demineralized water plant taking water from the ivew Orleans municipal supply. The demineralizer effluent will be fed to the condensate receivers on demand and, together with the condensate, pumped to the deaerating feed water heater. The boiler feed 
pumps take suction from the feed water heater and discharge to the boiler feed water header and thence to the economizers and into the boilers.

The system is totally flexible and is provided with dual equipment or bypass arrangements so that the plant would continue in operation with any one piece of equipment out of operation. Each demineralizer will be sized for $25 \mathrm{gpm}$, with a third unit provided in the future so that any two units on stream will supply the ultimate makeup requirements. The dual condensate receivers $c$ an be operated in tandem or separately.

The condensate transfer pumps are sized to handle total requirements with one in standby. The deaerating feed water heater is sized for the ultimate load of 340,000 pounds per hour and arranged for bypassing when out of service for repairs or cleaning.

The boiler feed pumps are presently sized for 200,000 pounds per hour, with the turbine driven pump unit sized for full load, or $410 \mathrm{gpm}$, and each of the two electric drive units sized for $210 \mathrm{gpm}$. In the future one electric drive unit could be removed and another $410 \mathrm{gpm}$ unit added.

\section{4.b.1.9 Turbine Generator Unit}

Steam from the boiler units will be discharged to the high pressure header $\left(1250 \mathrm{psig}-950^{\circ} \mathrm{F}\right)$ and fed to the turbine generator, which is a multistage back-pressure unit exhausting steam at 185 psig to the intermediate pressure header. The unit is sized for $9500 \mathrm{KW}$ output at 0.85 .power factor and a steam flow of 195,700 pounds per hour. The exhaust steam enthalpy will vary, with output ranging from 1317 BTU at $5000 \mathrm{KW}$ to $1295 \mathrm{BTU}$ at $9500 \mathrm{KW}$. The turbine generator output will be controlled by the amount of steam used from the 185 psig header for the production of heat or cooling required by the user institutions and the inplant auxiliary steam driven equipment. The control device will be a constant pressure regulator controlling the turbine steam admission valving.

In the event the turbine generator is inoperative, a pressure.reducing desuperheater station is provided to serve the requirements of the 185 psig header steam requirements.

\section{4.b.1.10 Intermediate 185 psig Steam}

Steam from this header is used to supply the turbine driven boiler feed pump, which exhausts to the low pressure header feeding the deaerating feed water heater, with a 185 psig to 10-15 psig pressure-reducing station providing additional steam as needed to the low pressure header. 
Steam from the 185 psig header is also used to supply the steam heating requirements of the users and is desuperheated to approximately 1200 BTU enthalpy as it leaves the plant and enters the distribution system.

Steam from this header is also used by the turbine driven refrigeration machines, and is then condensed and returned directly to the heater section of the deaerating feed water heater via steam condensers and hot well pumps serving each refrigeration unit.

\section{4.b.1.11 Cooling Plant}

The plant is equipped with three - 5000 ton steam turbine driven refrigeration machines. Each unit is designed to produce $8000 \mathrm{gpm}$ of chilled water at $40^{\circ} \mathrm{F}$ with return water at $55^{\circ} \mathrm{F}$, using $185 \mathrm{psig}$ steam at a rate of 9 pounds per ton, or 45,000 pounds per hour at full load of 5000 tons. This performance is also predicated on a condensing water temperature of $85^{\circ} \mathrm{F}$ and $15,000 \mathrm{gpm}$, with a $10^{\circ} \mathrm{F}$ rise through the refrigerant condenser and a $10^{\circ} \mathrm{F}$ rise through the steam condenser, utilizing series flow. The four-cell cooling tower is designed for a total of $45,000 \mathrm{gpm}, 20^{\circ} \mathrm{F}$ range, $85^{\circ} \mathrm{F}$ to $105^{\circ} \mathrm{F}$, with a wet bulb temperature of $80^{\circ} \mathrm{F}$. This system is provided with a complete standby capability of 5000 tons, i.e., any two units capable of handling the initial load.

Each of the four cooling tower cells will be equipped with two induced draft fans and stacks. The four cells will supply the condensing water needs of the three refrigeration machines through each machine's condenser water pump.

The three chilled water pumps will be capable of serving any machine through a pump discharge header system. The pump capacity will be equal to the requirements of each machine, i.e., $8000 \mathrm{gpm}$. Each machine discharge will flow to a common header system connecting to the chilled water supply distribution piping. The distribution return piping will connect to the chilled water pump suction header. This equipment will be started and stopped manually. Automatic controls will be used during the operating mode, being served by means of BTU recorder controllers for each chiller controlling leaving chilled water termperature at set point: The turbine governor will be responsive to the set point.

\section{4.b.1.12 Waste Disposal}

All wastes such as boiler blow down, cooling tower blow down, demineralizer backwash, flue gas scrubber waste, etc., will be piped to the waste disposal tanks. Solids will settle from the wastes into the tanks. The effluent water will be monitored and treated as required prior to discharge to the sewer. As required, when one waste disposal tank has become sufficientiy 
filled with settled material, the waste flow will be diverted to the second tank. The accumulated material will be removed and together with the accumulated ash, will be hauled to land fill.

\section{4.b.1.13 Distribution Systems}

Distribution mains for conveying the thermal products, i.e., steam and chilled water, from the central plant to the different HEAL complex buildings will consist, generally, of elevated steel pipe systems, insulated as required for the particular service and service conditions. The pipe systems will be supported on reinforced concrete supports and pile-supported foundations, with the supports designed to accommodate the pipe systems and the elevated pedestrian walkways that are contemplated for possible future installation above the pipe systems. Meter stations for each system will be provided at each building to be served, with the piping past those points, to and including connections to the individual building internal systems, the responsibility of that building's owner.

\section{4.b.1.14 Electrical System}

The primary connection to the utility company electrical grid will be through a 13.8 to $24 \mathrm{KV}$ transformation from the turbine generator output to the NOPSI Derbigny Station. A secondary connection at $13.8 \mathrm{KV}$ will be made to the NOPSI Notre Dame Station. Both connections to the grid will be equipped with in-and-out metering. The three sources of $13.8 \mathrm{KV}$ will be connected through metal clad protective and circuit isolating and synchronizing switchgear to a 13.8 KV synchronizing bus.

Redundant $13.8 \mathrm{KV}$ to $4.16 \mathrm{KV}$ transformers will effect a 13.8 to $4.16 \mathrm{KV}$ transformation to provide the lower voltage for operation of the large horsepower motors in the plant. These motors will be controlled by power fuse-protected magnetic starters contained in a $4.16 \mathrm{KV}$ Motor Control Center located in the electrical equipment area of the plant.

Redundant 4160 to 480 volt transformers will also be served by the $4.16 \mathrm{KV}$ switchgear to provide the lower voltage for operation of the smaller horsepower motors in the plant. The transformers will be located in a vault in the electrical equipment area.

The small horsepower motors will be controlled by molded case, circuit breaker-protected magnetic starters contained in 480 volt control centers.

Plant lighting and miscellaneous and convenience loads will be serviced by the 480 volt system through necessary transform- 
ations to the proper voltages as required throughout the plant. 


\section{4.b.2 PRELIMINARY PROCESS, PIPING AND INSTRUMENT SCHEMATICS}

Preliminary process and piping is shown on the drawing which is part of this Section. Instrumentation Schematics appear with the material in part 4.b.3.2 of Section 4.b.3. 


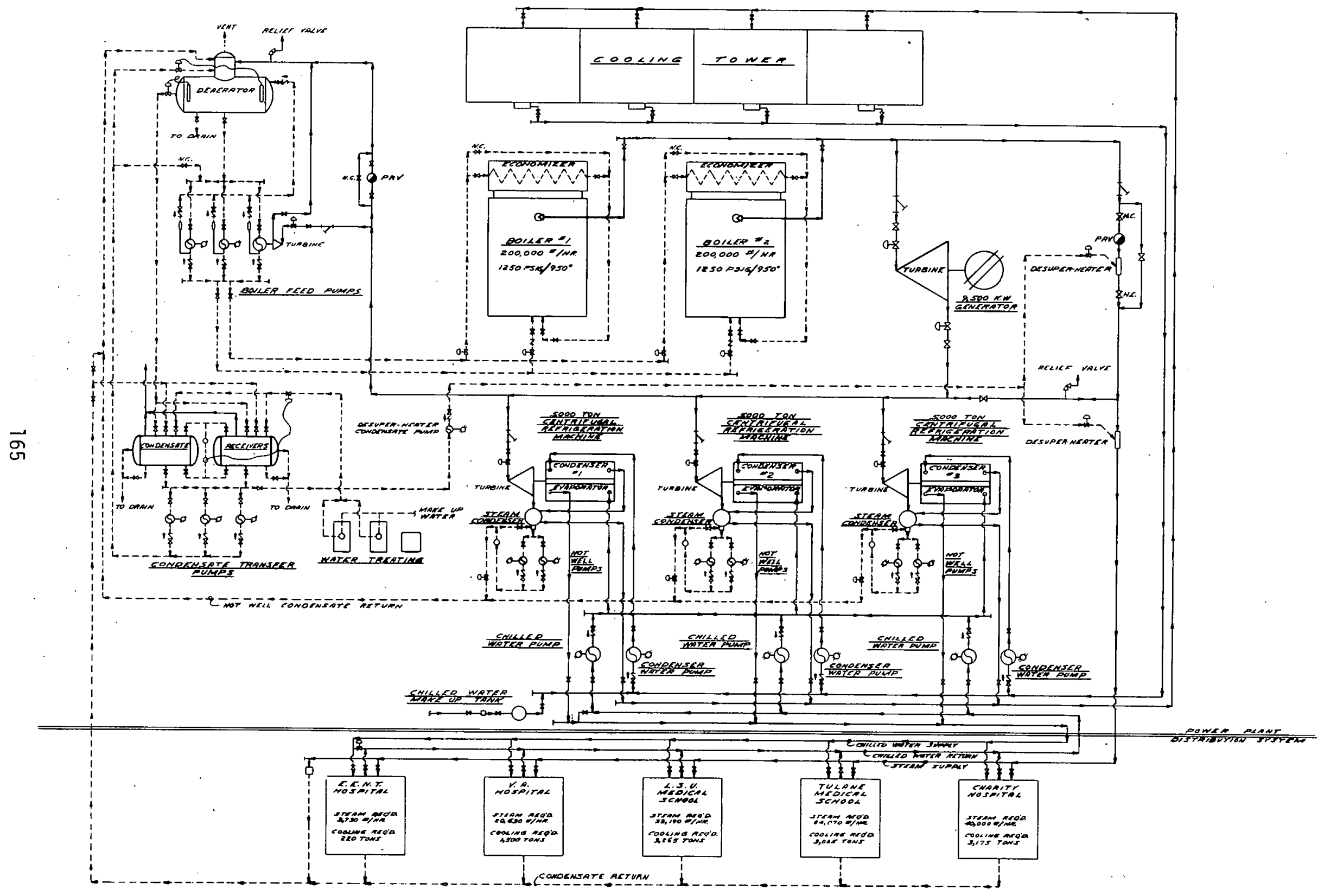


4.b.3.1 Equipment Schedule - Initial Plant Design

a) Boilers - (2) $200,000 \# / \mathrm{hr}$. 1250 psi o $950^{\circ} \mathrm{F}$.
1) Stokers (2)
2). Forced Draft Fans (2)
3) Dust Collectors (2)
4) Economizers (2)
5) Ductwork
6) Breeching

b) Flue Gas Scrubbers (2)
1) Scrubber Chemical Tank and Pump
2) Scrubber Recycle Tank and Pump
3) Scrubber Recycle Pump Tank and Pump
4) Scrubber Transfer Tank and Pump
5) Induced Draft Fans and Drives (2)

c) Pumps
1) Motor Driven Boiler Feed Pumps (2)
2) Turbine Driven Boiler Feed Pumps (1)
3). Condensate Transfer Pumps (3)
4) 0 i T Transfer Pumps (2)

d) Deaerator (1)

e) Condensate Tanks (2)

f) Coal Handling
1) Truck Hopper
2) Under Hopper Conveyor
3) Coal Crusher
4) Coal Crusher Conveyor
5) Under Silo Conveyor
6) Coal Elevator
7) Over Silo Conveyor
8) Over Bunker Conveyor
9) Coal Bunker
10) Under Bunker Conveyor
11) Coal Scales (2)
12) Coal Valves (19)

g) Ash Handling
1) Intake Gates (Hopper)
2) Intake Gate (Stack)
3) Ash Pipe
4) Ash Separator
5) Steam Exhauster
6) Air Washer
7) Filter Vent
8) Dustless Untoader 
h) Chilled Water System

1) Refrigeration Machines (Chiller Units) (3)

2) Chilled Water Pumps (3)

3) Steam Condensers (3)

4) Condenser Water Pumps (3)

5) Cooling Towers Cells (4)

6) Cooling Tower Fans and Drives.(8)

7) Hotwel1 Pumps (6)

i) Turbine Generator (1)

j) Air Compressors (2)

k) Water Treatment Equipment

1) Demineralizers

1) Transformers

1) 13.8 to $24 \mathrm{KV}, 10,000 \mathrm{KVA}$ (1)

2) 13.8 to $4.16 \mathrm{KV}, 7500 \mathrm{KVA}$ (2)

3) $4.16 \mathrm{KV}$ to 480 volt, $2500 \mathrm{KVA}$ (2)

m) Metal Clad Switchgear

1) $24 \mathrm{KV}$ isolation (1)

2) $13.8 \mathrm{KV}$ isolation (4)

3) $4.16 \mathrm{KV}$ isolation (2)

4) Metering Systems (3)

5) Synchronizing Systems

n) $4.16 \mathrm{KV}$ Distribution

1) Motor Control Units (16)

2) 480 Volt Transformation (2)

0) 480 Volt Distribution

1) Motor Control Centers (4)

2) $480 / 277$ Volt Load Centers (4)

3) $120 / 203$ Volt Transformation (4)

4) $120 / 208$ Volt Load Centers (4) 
MOTOR HORSEPOWER SCHEDULE

Present Standby Total Future Total

Boilers 1

Future 3

F. D. Fans 1

Future 3

I. D. Fans 1

Future 3

B. F. Pumps 1

Future 3

Air Compressor 1

Coa? Elevator 1

Future

Coal Silo Conveyor Feeders 1

Coal Crusher 1

Coal Conveyors:

1. Hopper

2. Crusher

3. Under Silo

4. Over Silo

5. Over Bunker

Condensate Transfer

Pumps 1 .

2.

13.

Hot Well Pumps:

Chiller \#1 1.

Chiller \#2 1 .

Chiller \#3 2 .

Chitler \#3 1

Future Chiller \#4 1.

2.

Future Chiller \#5 1.

2.

Chilled Water Pumps

Condenser Water Pumps
60

75

750

350

350

50

20

50

60

75

750

15

30

15

10

10

10

10

15

10

10

10

10

10

10

10

10
750

700

350

100

20

20

30

30

30

30

10

30

60

180

225

2250

1050

100

40

55

20<smiles>C1CCCC1</smiles>

$\begin{array}{ccc} & 10 & \\ & 10 & \\ & 10 & \\ & 10 & 100 \\ & & \\ & & \\ 1200 & 400 & \\ & 400 & 2000 \\ & & \\ & & \\ & & \\ & 400 & \\ & 400 & 2000\end{array}$


$\underline{\text { Present }}$ Standby Total Future Total

Cooling Tower Fans:

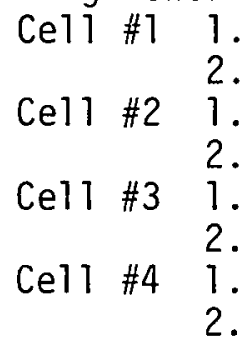

Future Cell \#5 1.

Future Cell \#6 2.

Coal Scales:

1.

2.

3.

Misc. Motors
125

125

125

125

125

125

125

125

1000

125

125

125

125

1500

7.5

7.5

15

200
22.5

200

7.5

100

300

6400
3512
9912 


\section{4.b.3.2 Instrumentation}

\section{a) General}

Instrumentation and control will be provided to insure optimum efficiency in the plant. It is intended to utilize the latest "state of the art" direct digital control (DDC), incorporating microprocessors, to provide an effective means of obtaining maximum operating efficiency. Through the use of DDC, we can continuously scan/monitor points, updating any new information, and making necessary adjustments to the control system. This continuous and automatic updating process is also intended to reduce operator staff and labor dollars.

The instrumentation and control system will be modular in design and expandable.

The operator will receive recorded information only on the points over which he has control, in other words, the variable inputs. other important monitor points will be shown on indicators. The majority of the monitor points, however, will be monitored only and indicated only under an alarm condition. With the DDC control we have instant recall of any or all monitored points in the system.

A trend recorder will be provided for selected data.

An alarm printer will automatically record any alarm that indicates at the central control console.

The central control and printer will have a cathode ray tube (CRT) which will display on recall any of the set point settings in actual figures, for example:

Pt. \#13 Superheat Steam Temp. BLR \#1 $947^{\circ} \mathrm{F}$ Hi Alarm Set $965^{\circ} \mathrm{F}$

Pt. \#2 0xygen BLR \#1 $3.6^{\circ}$ Lo Alarm Set $2.9 \%$

Also, any control loop displayed on CRT will give all parameters included in that control loop.

Capability will be provided for changing any of the set alarm or control points at the central control console.

The central console will also collect data from remote points in the system. These points will be located at each one of the users and also at the ends of the runs in the distribution system. A hard copy (recorder) will also be located at each one of the user locations for verification of the monitor points at that particular location.

b) Description of the Control System

The control equipment will be designed for fully automatic operation of the boilers, arranged to control the rate of combustion or furnace heat release by properly controlling the fuel air ratio at maximum combustion efficiency modulating from peak boiler load down to 20 per cent of load. 
The plant header pressure will be sensed by the plant master header pressure transmitter and converted into an appropriate milliamp signal and transmitted as a measured variable to the plant master pressure control. In this control the plant master pressure signal will be compared to the set point, and any deviation between the measured variable and the set point will cause the plant master pressure control to take the appropriate corrective action and simultaneously either increase or decrease the master loading signal to each of the steam generators.

The plant master loading signal will be fed simultaneously to each of the steam generators through the boiler master manual-automatic control loop having an integral biasing feature which will enable the operator to adjust the load on one steam generator with respect to other units.

The master demand signal will then be fed simultaneously to the high signal selector and the low signal selector, whose functions will be to provide a lead-lag feature which will insure that the air will always precede the fuel on an increased demand in the firing rate and will always lag the fuel on a decreased demand in the firing rate.

The master loading demand signal will be compared to the fuel flow signal in the high signal selector, and the higher of these two signals will then be fed through the fuel air ratio, where it will be corrected for excess air (oxygen compensated) and then fed into the air flow control as setpoint.

The air flow control will continuously compare its measured variable signal received from the air flow transmitter to the constantly updated setpoint signal. Any deviation of measured variable compared to the setpoint will cause the air flow control to take the appropriate corrective action and reposition the forced draft control equipment.

Meanwhile, the master demand signal will be compared to the air flow signal in the low signal selector, and the lower of these two signals will be fed into the fuel flow control as setpoint.

The measured variable obtained from the steam flow transmitter will be compared to the setpoint of the fuel flow control, and any deviation of measured variable from a setpoint will cause the control to take the appropriate corrective action to reposition the fuel feed equ ipment.

The direct digital semi-metering type control system will control a total of three (3) boilers (one future), all having traveling grate spreader stokers.

A fuel-air ratio control will be an integral part of the control calculation but will be manually adjustable and imitable via data entry into the computer.

The control system will be a totally dedicated and integrated microcomputer system allowing digital control of the combustion process equ ipment.

This system will utilize standard analog input signals. 
All feedwater, air, fuel and draft control loops will have manual back-up control at the operator's console.

c) Control Devices

There will be individual drives for each element: air, feedwater, fuel, furnace draft, boiler blowdown, etc.

All drives will be furnished complete with all necessary clevises, rods and brackets. Each actuator will have means to be manually operated in the event of a power failure.

Actuators will be of the electric type with adjustable integral limit switches and reversible motors.

These drives will be actuated directly from the digital control system.

The following equipment will be an integral part of the system:
1) Operator control panel
2) System software
3) CRT monitor:
4) Printer
5) Analog input/output process modules
6) Contact closure process modules
7) Acquisition modules
8) System status module

d) Operator Control Panel

The operator control panel will be a rack mounted integral part of the operator console and will provide a means for entering data into the various loops.

Thumbwheel selection of each loop, function and data to be entered will be included. A digital display will be four digits, a decimal and a plus or minus sign, in direct engineering units.

In addition, an alarm acknowledge button, data entry buttons and a security lock will be integral to this control panel.

The operator control panel will provide complete control of all boiler process variables at a central point, including manual overrides and displayed variables. It permits modification of controlled variables or constants such as setpoints, 1 imits, or control constants. The panel features LED display, and a protective panel lockout.

e) Contact Closure Process Modules

Contact closure process modules will be provided to act as annunciators and provide status lights and alarm indication. Through these modules, a hard copy printout can be generated.

A contact closure input module determines if a field contact is open or closed, and relates this information to the system. A contact closure output module is one which can energize or de-energize a field relay, solenoid, or similar device. Each input has a light to 
indicate that the specified contact is closed or open, and an alarm light which is program-controlled. Each output has a light to indicate that the output contact is closed or open, plus an optional manual switch which is used to override the program or make manual change in the process. The controller checks the status of the mode switch before executing control of the contacts and does not proceed unless the switch is in the control mode. The lights on the contact modules will indicate the status of the process.

Acquisition only modules will be used only where inputs need to be monitored. Alarm lights will be provided for each monitored point.

Due to the number of inputs and outputs, a common alarm light will not be suitable; each function will have its own alarm status light.

A system status module will be provided to permit scanning of all critical system parameters and serves as a self-check monitoring device for DC level power supply inputs, analog/digital converter accuracy and PROM memory integrity. It will also log fault information to quickly locate component malfunction and permit prompt repairs. It may be interrogated locally, or, optionally, over longer distances, or via telephone lines, or any standard data transmission system.

Conversion from $A / D$ and $D / A$ signal shall be performed by one converter for each direction.

f) Control Loops

The following control loops will be furnished for each boiler or all boilers, as the loop applies to the system.

1) Main steam header pressure loop

2) Fuel feed loop

3) Air flow loop

4) Oxygen compensation loop

5) Feedwater 3-element loop

6) Super heat control loop

7) Continuous blowdown loop

\section{g) Indicators}

Dedicated analog input meters, one parameter per meter, will monitor boiler functions as indicated on the function sheet.

These electronic type modules will be used primarily for remote indication where monitoring without control is necessary and will intercept the inputs to the direct digital control system.

h) Field Sensors and Transmitters - General

Each field sensor-transmitter will meet the following requirements:

All transmitters will be of the two-wire type wherever possible. (Use of 115 VAC to the instrument is 1 imited only to these instruments where power greater than for measurement is required.) A 24 VDC, fused, power source at the Instrument/Multiplexer Termination Cabinet will 
power the remote transmitters. A separate power supply will be provided for the local panel for use in the manual operating mode.

The instruments will be of rugged construction and designed for use in an industrial environment and the environment where installed.

Instruments shall return in a reasonable period of time to accurate measurement upon restoration of power after a power failure.

i) Pressure and Differential Pressure Transmitters

This section describes the general requirement for pressure and differential pressure type transmitters for measuring pressure, differential pressure, flow and level.

The function of each transmitter is to generate and transmit an analog signal, which is proportional to the measured process variable, to a device or devices as specified. Acceptable analog output signal is 4-20 mA DC.

Transmitters will be of the force-balance type, with overrange protection to at least $1-1 / 2$ times the maximum expected operating pressure.

To facilitate transmitter calibration, all transmitters will have non-interacting range and zero adjustments. All transmitters will have interchangeable amplifier and calibration modules.

Transmitter will be housed in a durable aluminum case, which will protect all working parts and be suitable for installation in the location indicated.

Each sensing leg will be equipped with a suitable instrument shutoff valve, and a suitable drain valve. All wetted parts will be 316 stainless steel.

Additionally, each differential pressure type transmitter will be equipped with a suitable 3-valve, equalizing process manifold, mounted or attached to the transmitter in such a manner as to allow the transmitter to be detached and removed for maintenance.

Each transmitter will have the following capabilities:

1) Accuracy: $+0.5 \%$ of span

2) Hysteresis: $\pm 0.25 \%$ of span

3) Repeatability: $+0.1 \%$ of span

4) Linearity: $\pm 0.2 \overline{5} \%$ of span

5) Sensitivity: $+0.1 \%$ of span

6) Ambient Temperāture Effect:

Temperature differential $100^{\circ} \mathrm{F}- \pm 1.0 \%$ of span

\section{j) Temperature Measuring Devices - Thermocouples}

This section describes the general requirements for thermocouples for use in electrical measurement of temperature. 
Each temperature element and temperature test well must provide a reliable, safe facility for temperature measurement. Each temperature element must provide a continuous and accurate determination of temperature for use as specified on the function sheets.

Each thermocouple will have an accuracy as defined by the ANSI standard C96.1.

Each temperature element and well will have sufficient immersion in the medium being measured to avoid errors due to conduction of heat to or away from the measuring point.

All thermocouples will have their hot junctions formed by a butt weld. All sealed-type thermocouples will be grounded.

Ceramic insulator type thermocouples will have their hot junctions safely and securely covered with a ceramic cap to prevent contact of hot junction and protection well.

Packed magnesium oxide insulation will be used in all sealed-type thermocouples; ceremic insulator covered-type shall use high strength ceramic beads.

Sealed-type single-element thermocouples will be made of 16 AWG wire, and dual-element of 18 AWG wire. Ceramic insulator covered-type will be 14 AllG wire. Thermocouples will be Type K nickel chromium and nickel aluminum.

Thermocouple extension wire will have the type of insulation and protective covering required for the particular service. Within the temperature range to which the extension wires are exposed, they will have the same thermal/emf characteristics as the thermocouple leads with which they are used.

Design of thermocouples will be in accordance with ASME supplement to Power Test Codes, TPC 19.3 Instruments and Apparatus - Part 3 Temperature Measurement, and shall meet the requirements of ANSI Standard for Temperature Measurement Thermocouples C96.1 - 1964.

The head will be constructed of cast polished aluminum with a threaded cover. Cover will be furnished with a chain attached to the head and have a suitable gasket to ensure a watertight enclosure.

A ground screw will be provided inside the head for grounding extension wire shielding.

Lagging extensions will be provided where necessary.

Each thermocouple will have a two wire millivolt/analog signal transducer to generate and transmit a linear analog signal which is proportional to the measured process temperature. Transducers will be interchangeable between thermocouples. The analog signal output will be 4-20 mA D.C.

k) Temperature Measurement Devices - Resistance Temperature Detectors

This section describes the general requirements for Resistance Temperature Detectors (RTDs) for use in electrical measurement of temperature. 
Each RTD will have the following characteristics:

\author{
Resistance at $0^{\circ} \mathrm{C}$ \\ Sensitive material \\ Long Term Stability \\ Response time for step change \\ Wiring \\ Accuracy
}
100 ohms (nominal)
Platinum preference grade
(99.999\% pure) strain free $+0.05^{\circ} \mathrm{C}$
Less than $5 \mathrm{sec}$. for $63 \%$
3 wire to transducer
$\pm 10 \mathrm{~F}$

RTDS will have two wire resistance to analog signal transmitter to generate and transmit a linear analog signal proportional to the measured process temperature. Transmitters will be interchangeable between RTDs.

Each temperature element and well will have sufficient immersion in the medium being measured to avoid errors due to the conduction to or away from the measuring point.

The sensing element will be made of high purity platinum wound on a ceramic core and will be stress relieved and immobilized against strain or damage. The sensing element will be mounted on a stainless steel sheath in a manner to provide good thermal transfer and protection against the measured medium and moisture.

The connection head will be constructed of cast polished aluminum with a threaded, watertight, chain-attached cover.

1) Air Flow Measurement Device

The air flow measurement will be accomplished through an averaging type Pitot Tube. The differential from the Pitot Tube will be measured on a differential transmitter.

m) Opacity (Smoke Density) Measurement

Visual Emission Monitor systems of the double pass, optical transmissiometer type will be provided to continuously measure the emission density in the stack. The visual emission monitoring system will conform to Environmental Protection Agency and Louisiana Air Control Commission regulations and specifications.

The visual emission monitoring systems will have the following characteristics:

Transmissometer:

Angle ov View: Less than $+2.5^{\circ}$ from optical axis

Angle of Projection: Less than $+2.5^{\circ}$ from optical axis Spectral Response: 400 - 700 nañometers, with peak and mean response within 500 - 600 nanometers

Light Source: Tungsten filament, expected life greater than 15,000 hours

Temperature Ranges: $40-130^{\circ} \mathrm{F}$

Opacity Monitor:

Range: 0 - 100\% opacity

Calibration error: Less than $3 \%$ opacity 
Calibration drift (24 hour): Less than $2 \%$ opacity

Zero drift (24 hour): Less than $2 \%$ opacity

Response time: 5 seconds (maximum)

Air Purge: An air purge system will be provided with the visual emission monitor to keep the optical windows free of dust and deposits and automatigaliy operated shutters to prevent smoke and dust from entering the optica?

areas. The shutters will be operated upon a loss of air pressure or power and may be operated during maintenance functions to prevent flue gas exit.

Controls and signals:

The following controls and signals will be provided:

Opacity: A 4-20 mA DC signal proportional to opacity measured

Calibrate: A contact closure, indicating when in calibrate mode, rated at $115 \mathrm{~V}, 5$ amp.

Shutter: A contact closure, indicating when shutter is closed, rated at $115 \mathrm{~V}, 5$ amp.

n) Oxygen Analyzer

An in-stack oxygen analyzer will be provided to measure the oxygen in the flue gas. The oxygen analyzer will operate with a probe in the hot flue gas, and will not require sample piped from the fiue gas duct to the analyzer.

The oxygen analyzer system will provide a 4-20 mA DC output proportional to the oxygen in the flue gas.

The oxygen analyzer will be field repairable.

The analyzer will have measurement ranges of $0-1,5,10$ and 25 per cent linear.

System accuracy is $+2 \%$.

Analyzer resolution will be $.01 \% \mathrm{O}_{2}$.

Calibration of the analyzer will be performed without removing the sensor from the flue gas duct.

Output signal: 4-20 mA DC signal, isolated proportional to $\mathrm{O}_{2}$ level.

A contact closure will be provided to indicate when unit is in calibrate mode.

o) Conductivity Transmitters

Conductivity transmitters will be provided for measurement and control of solution concentration. Conductivity will be metered at the control console. Conductivity cells (or electrodes) will be provided as sensors to measure the conductivity of the various systems as indicated in the schedule. Temperature compensation will be provided to ensure the accuracy of the measurement. 


\begin{tabular}{|c|c|c|c|c|c|c|c|c|c|}
\hline $\begin{array}{l}\text { Point } \\
\text { No. }\end{array}$ & Description & 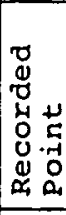 & 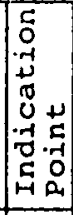 & 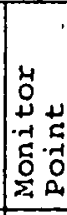 & 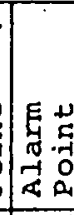 & $\left|\begin{array}{ll}-1 & \\
0 & 4 \\
4 & 4 \\
5 & 5 \\
0 & 0 \\
0 & 0\end{array}\right|$ & Sensor/Measurement Technique & Unit & Remarks \\
\hline $1 *$ & $\frac{\text { BOILER NO. } 1}{\text { Steam FIow }}$ & $x$ & & $x$ & & & Differential pressure/orifice & $1 \mathrm{~b} / \mathrm{hr}$ & \\
\hline $2 .^{\star}$ & Oxygen & $x$ & & $x$ & $x$ & $\mathrm{x}$ & zirconium-oxide probe/oxygen analyzer & 8 (wet & Alarm on low $\mathrm{O}_{2}$ \\
\hline 3.* & $\begin{array}{l}\text { Flue Gas Temp. out } \\
\text { of Boiler }\end{array}$ & $x$ & & $\mathrm{x}$ & & & Resistance bulb & $\begin{array}{l}\operatorname{deg} . F \\
\operatorname{deg} . C\end{array}$ & \\
\hline $4 .^{*}$ & $\begin{array}{l}\text { Flue Gas Temp. out } \\
\text { of Econ. }\end{array}$ & $x$ & & $x$ & & & Resistance bulb & $\operatorname{deg} . F$ & \\
\hline $5 . *$ & $\begin{array}{l}\text { Feedwater Temp. out } \\
\text { of Econ. }\end{array}$ & $x$ & & $\mathrm{x}$ & & & Resistance bulb & deg.F & \\
\hline 6. & Air Flow & $x$ & & $x$ & & & Pitot Tube/Diff. pressure Transducer & acfm & \\
\hline 7 . & F. D. Fan Pressure & & $\mathbf{x}$ & $x$ & & & Pressure/PE pressure rransducer & psig & \\
\hline 8. & Furnace Draft & & $\mathbf{x}$ & $x$ & $\mathrm{x}$ & & Pressure/PE pressure Transducer & psig & Alarm on high pressure \\
\hline 9. & Boiler Outlet Draft & & $\mathrm{x}$ & $x$ & & & Pressure/PE pressure Transducer & psig & \\
\hline 10 & Economizer Outlet Draf & & $\mathrm{x}$ & $\mathrm{x}$ & & & Pressure/PE pressure Transducer & psig & \\
\hline 11. & Scrubber Outlet Draft & & $\mathrm{x}$ & $x$ & & & Pressure/PE pressure Transducer & psig & \\
\hline $12 . *$ & $\begin{array}{l}\text { Smoke Indication on } \\
\text { Flue Gas Outlet }\end{array}$ & & $\mathrm{x}$ & $x$ & & & Light Absorption & 8 & \\
\hline $13 .^{*}$ & Steam Temp. & & & $x$ & $\mathrm{x}$ & & Resistance bulb & deg.r. & Alarm on high temperature \\
\hline 14. & Steam Pressure in Drum & & & $x$ & $\mathrm{x}$ & & Pressure/PE pressure transducer & psig & Alarm on high pressure \\
\hline $15 .^{\star}$ & Feedwatex Flow & $x$ & & $x$ & $\mathrm{x}$ & & Orifice Type Differential Flow & gpm & Alarm on low feedwater flow \\
\hline
\end{tabular}




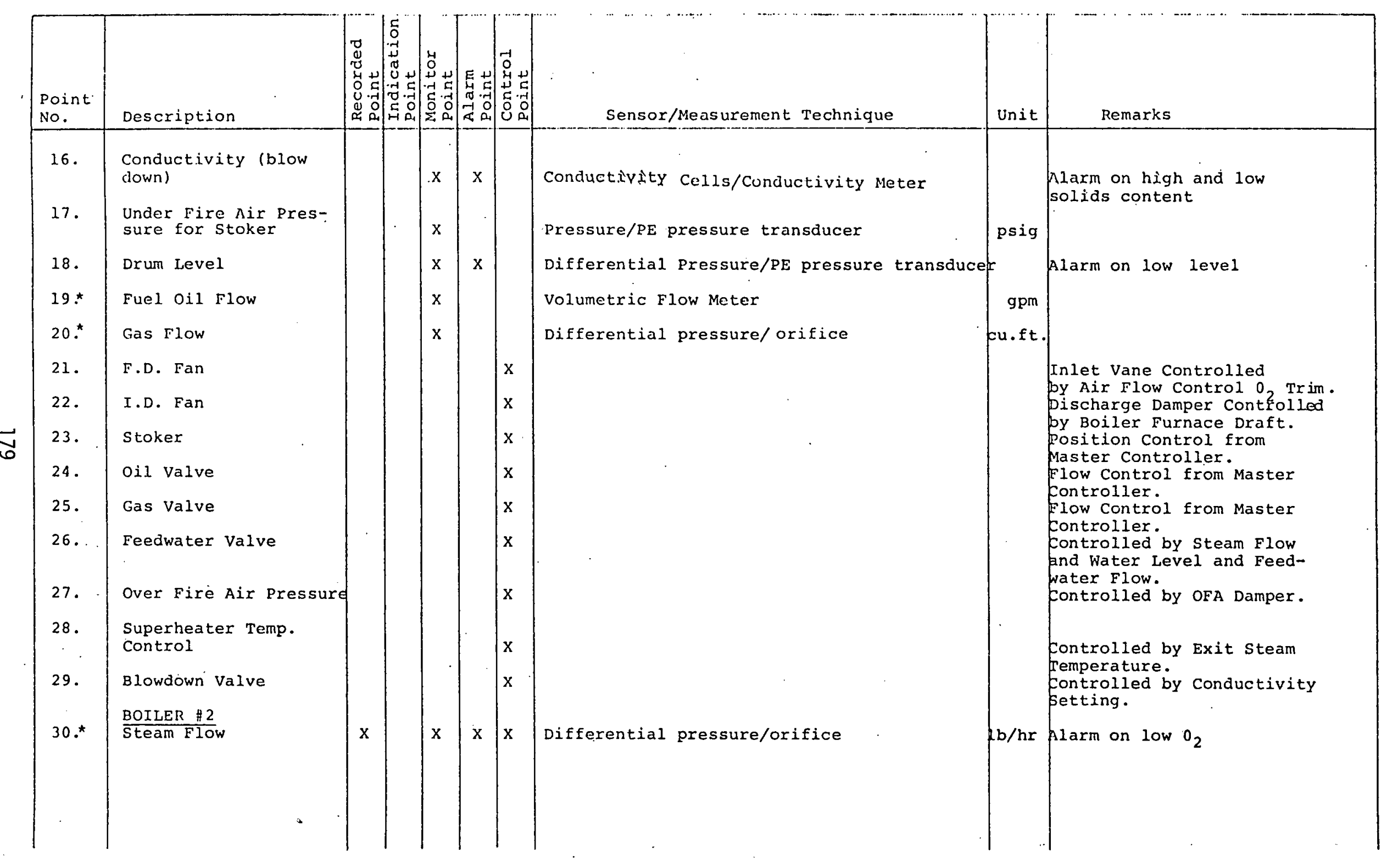




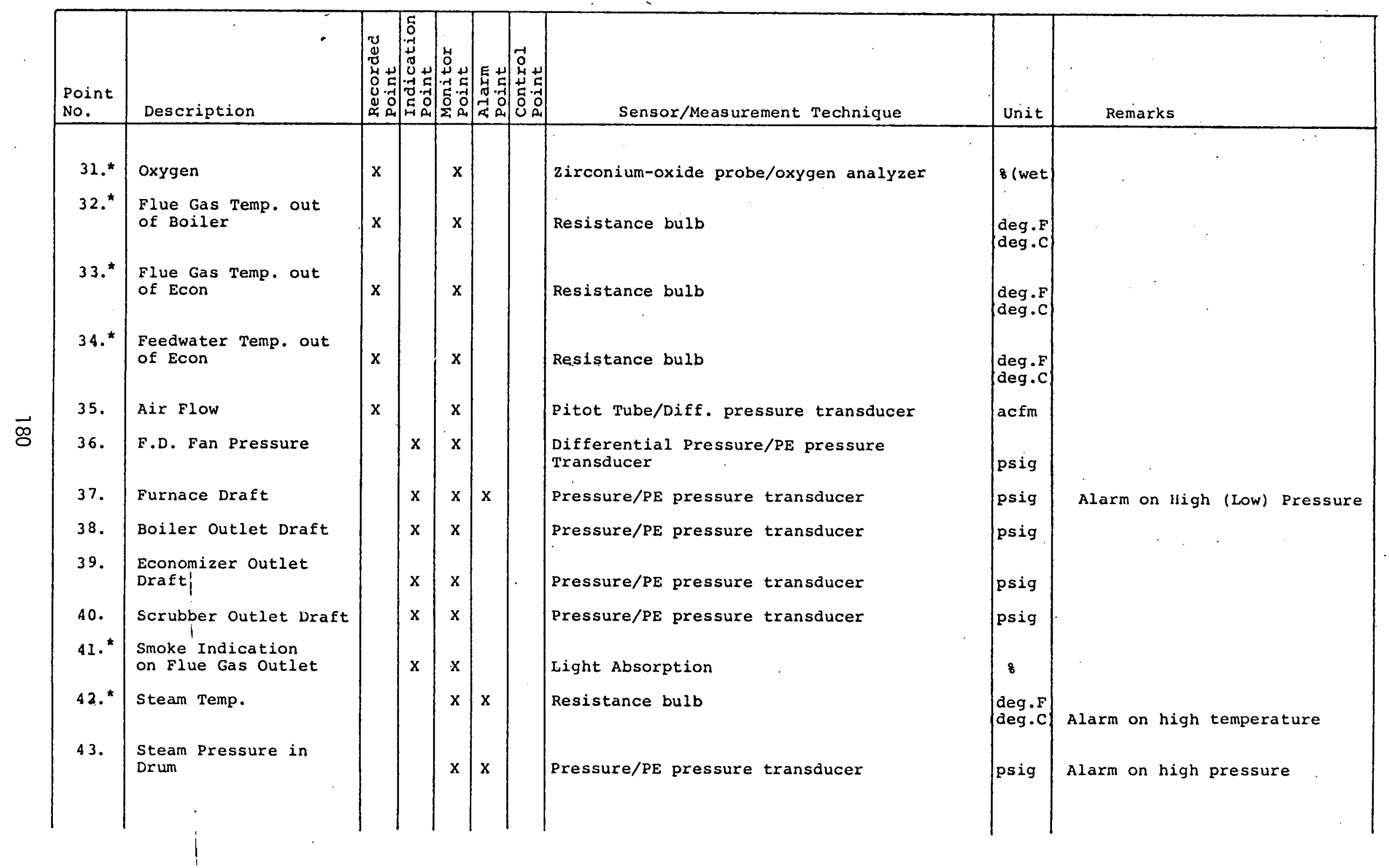




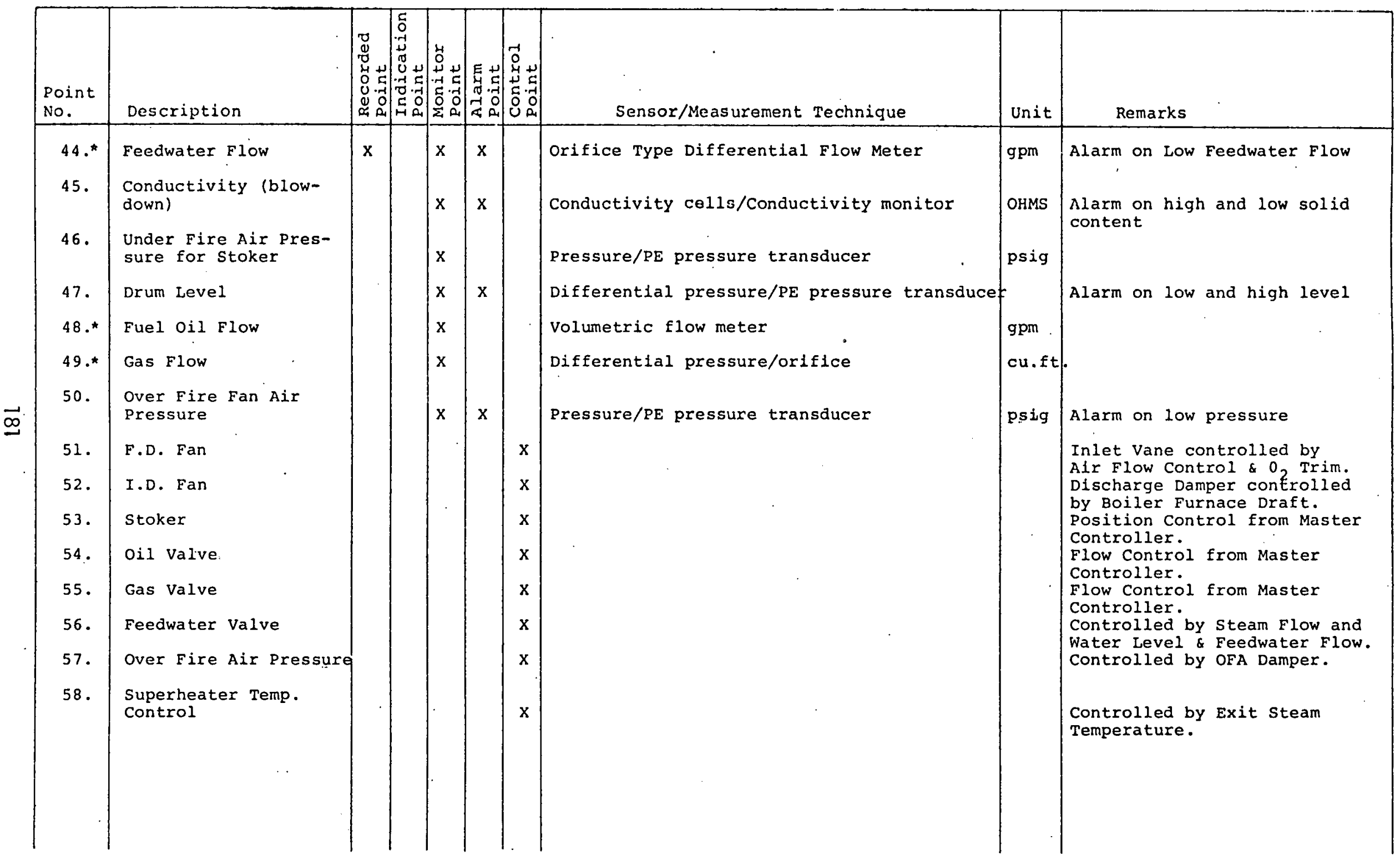




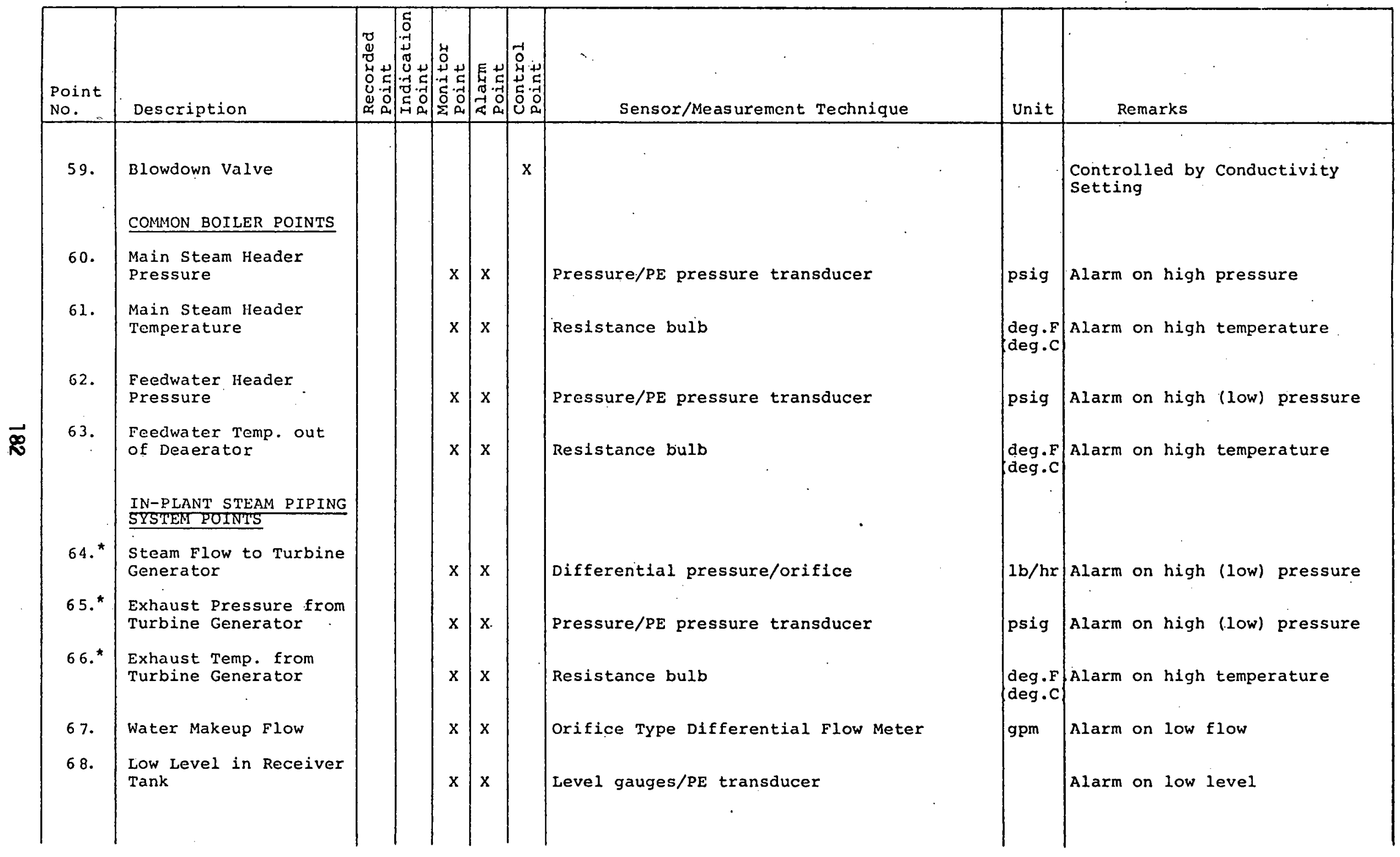




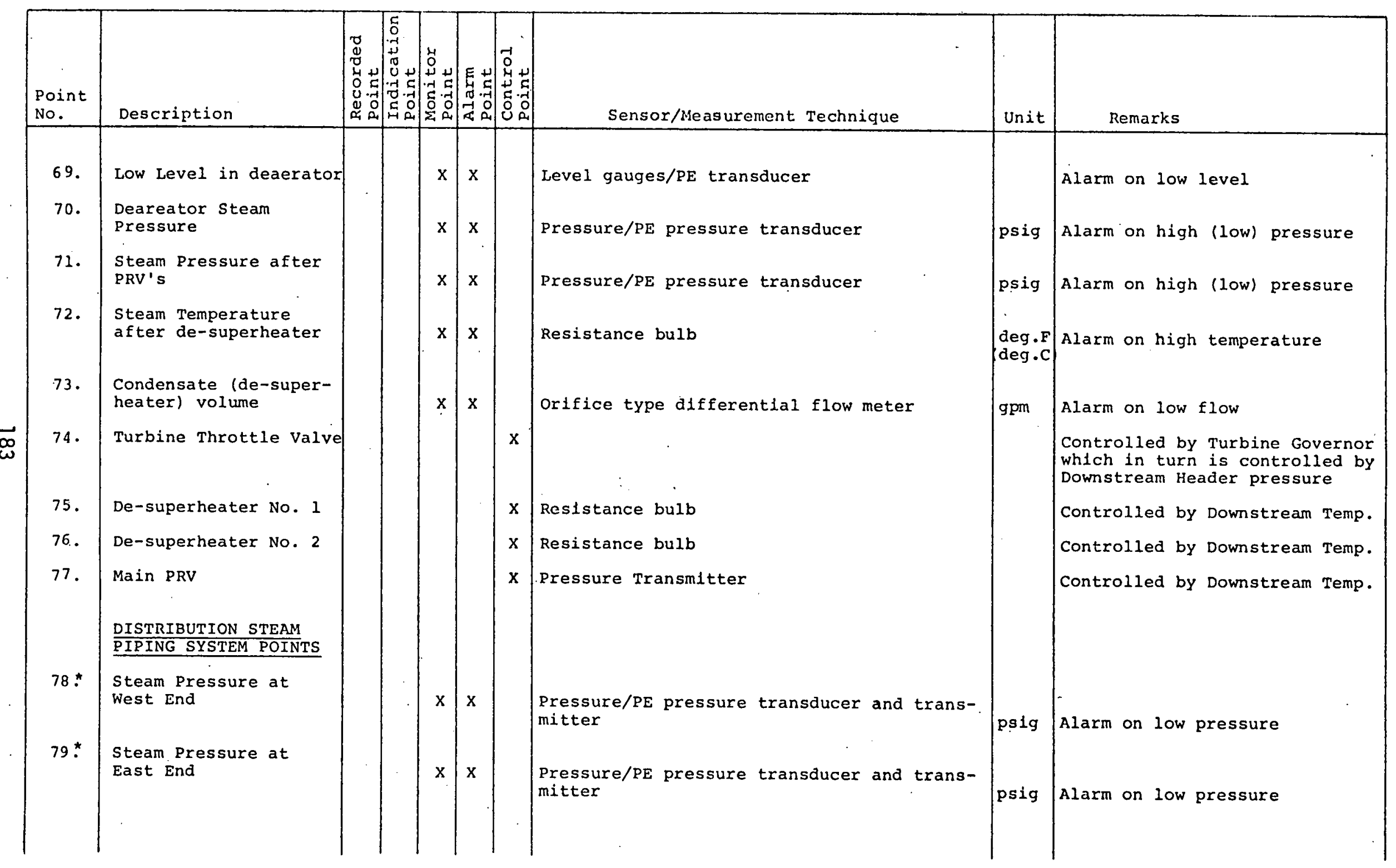




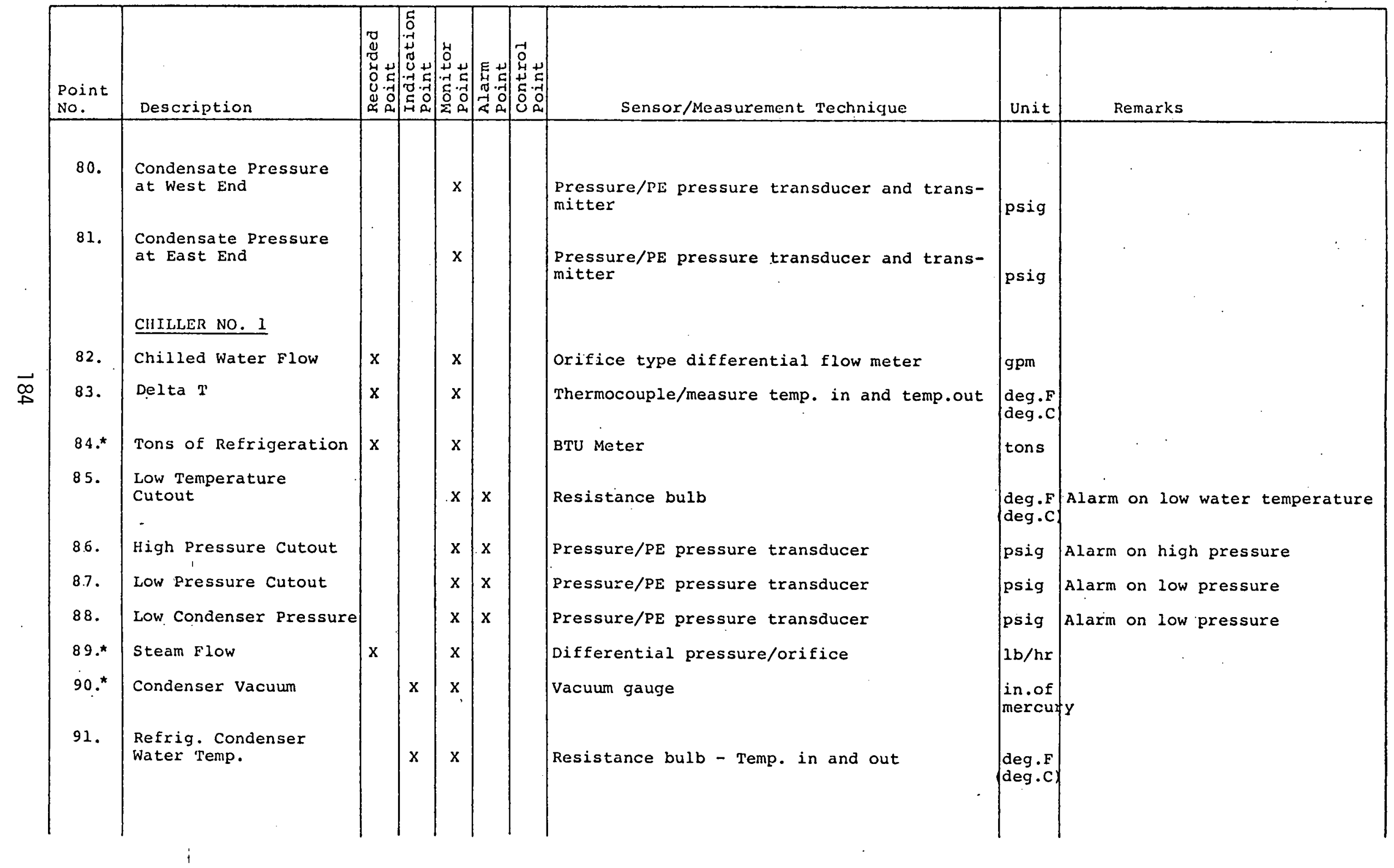




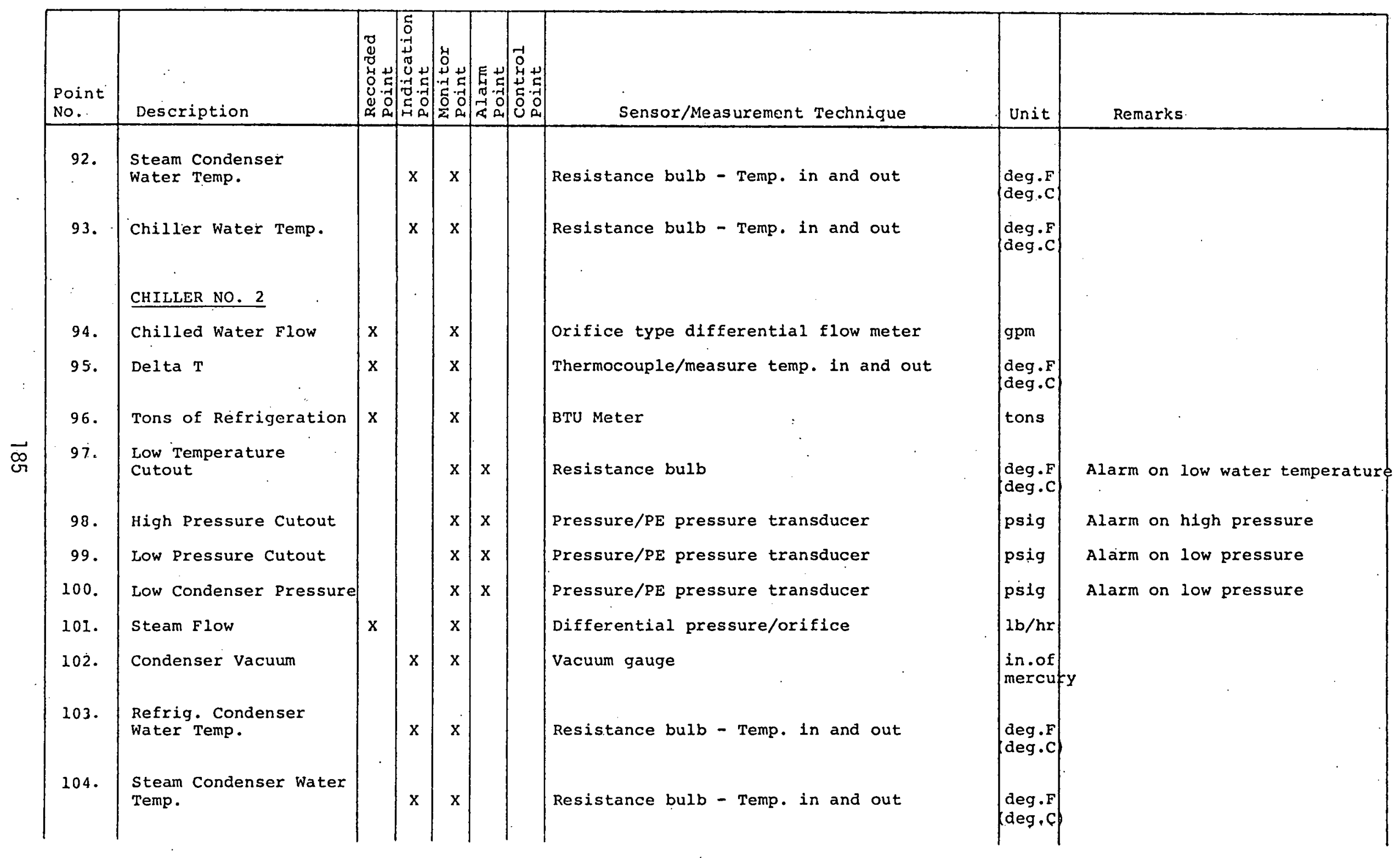




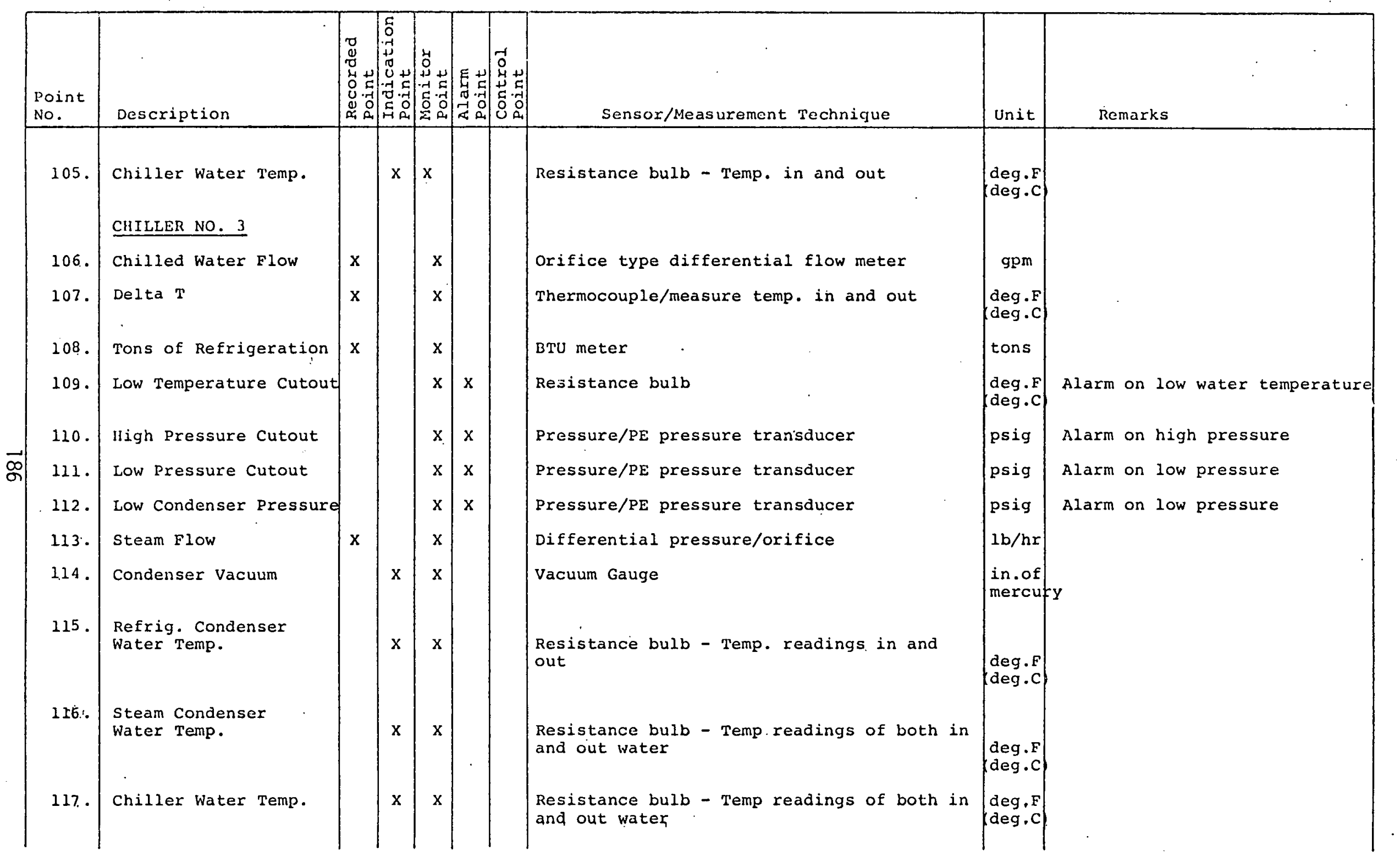




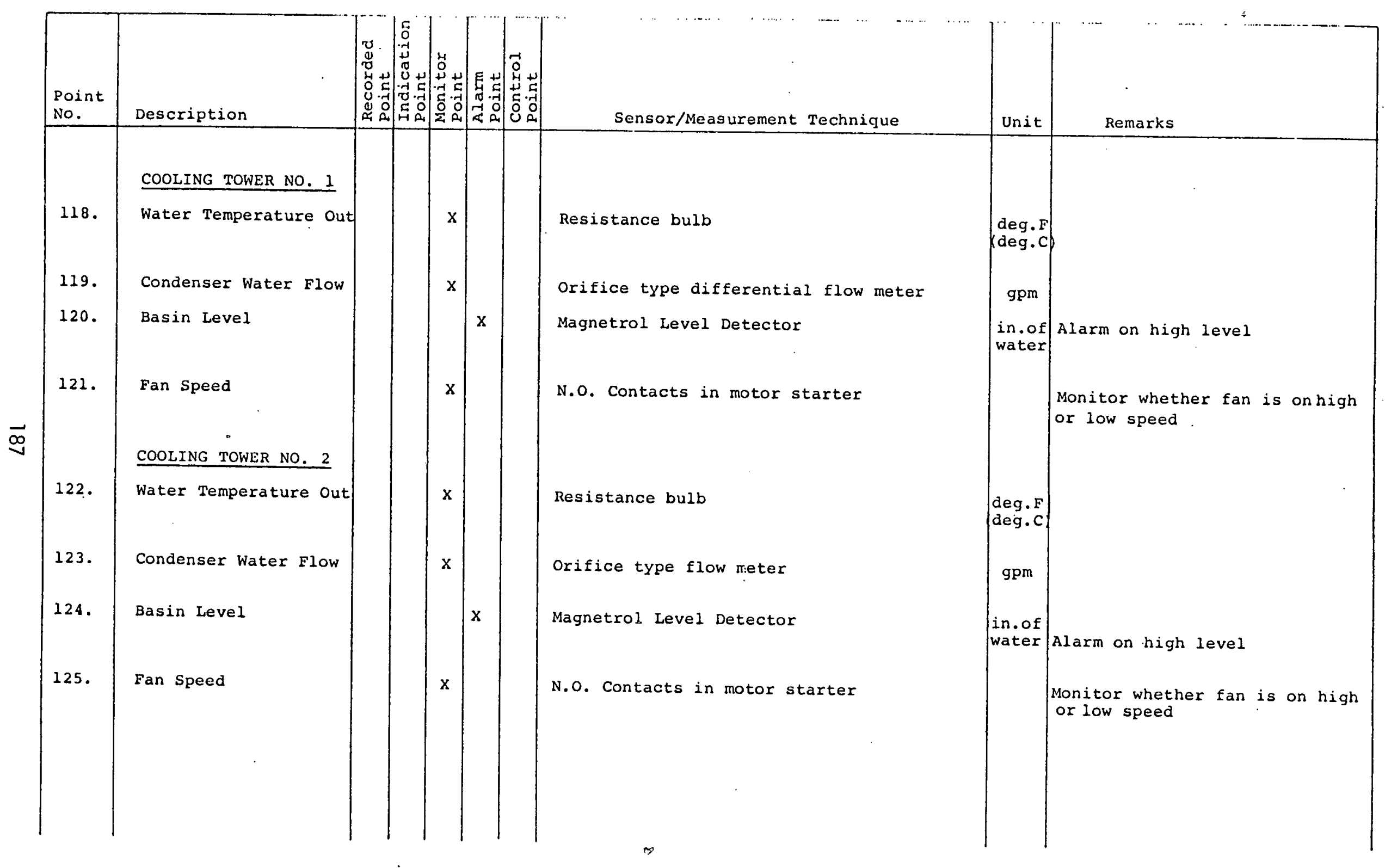




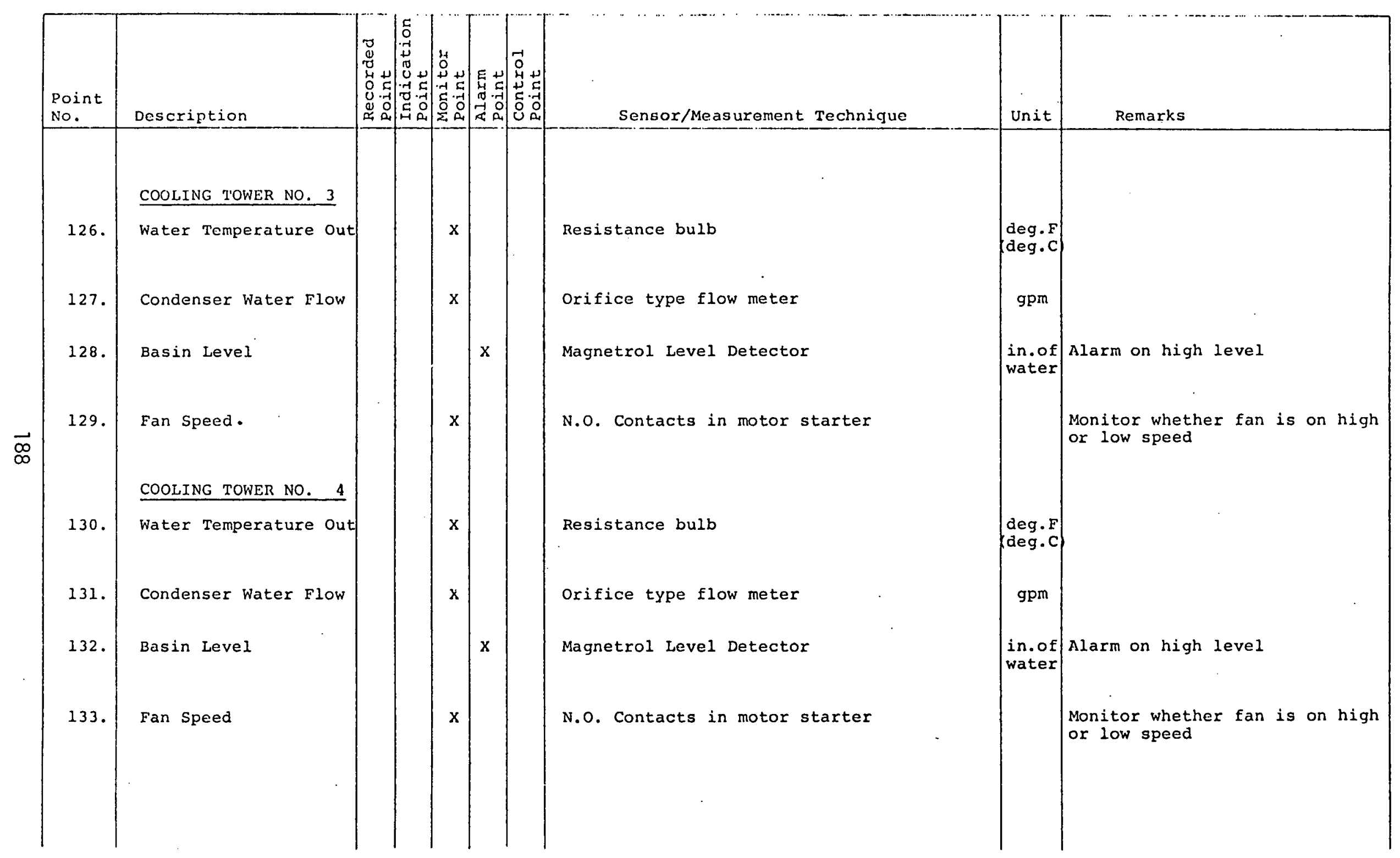




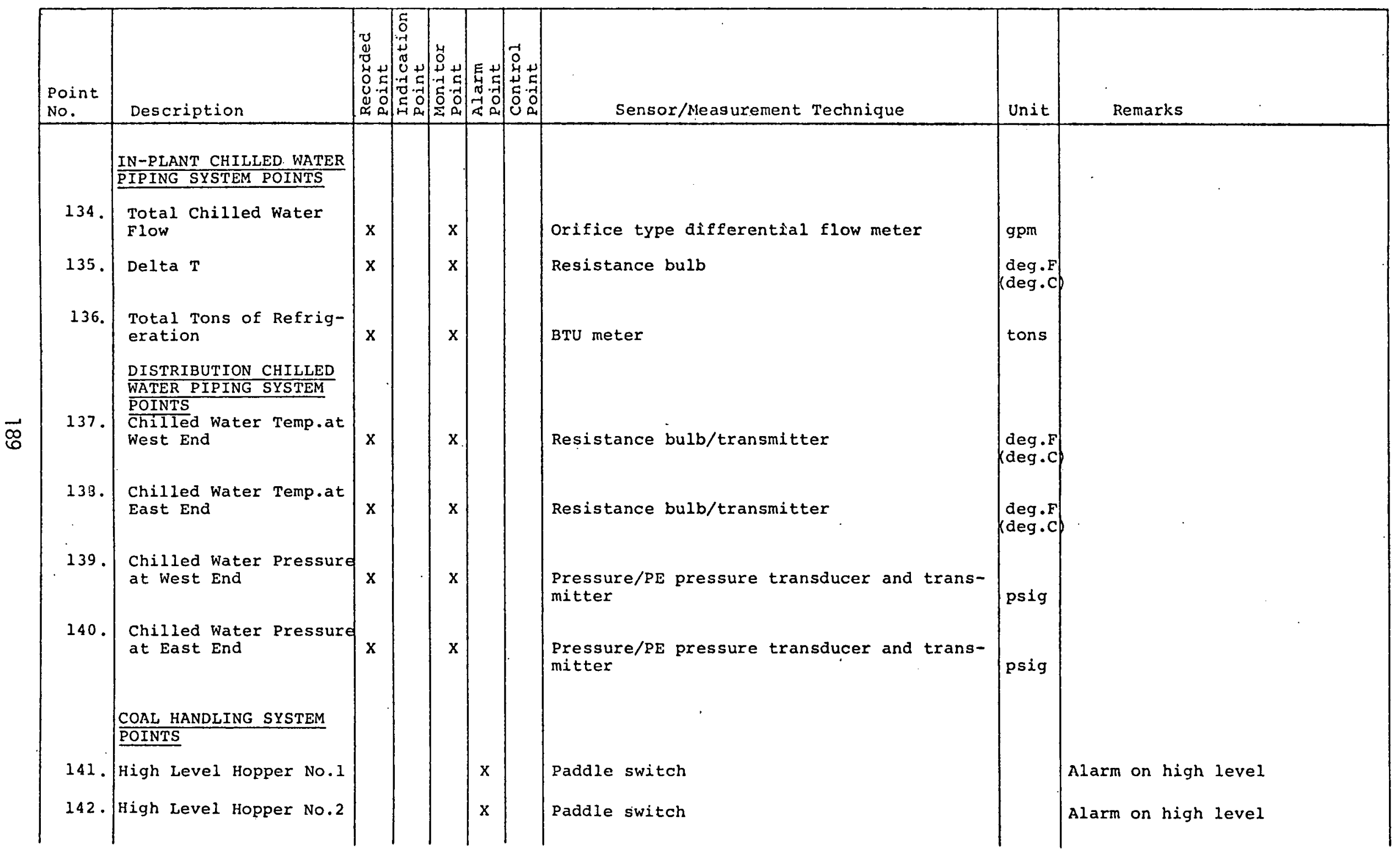




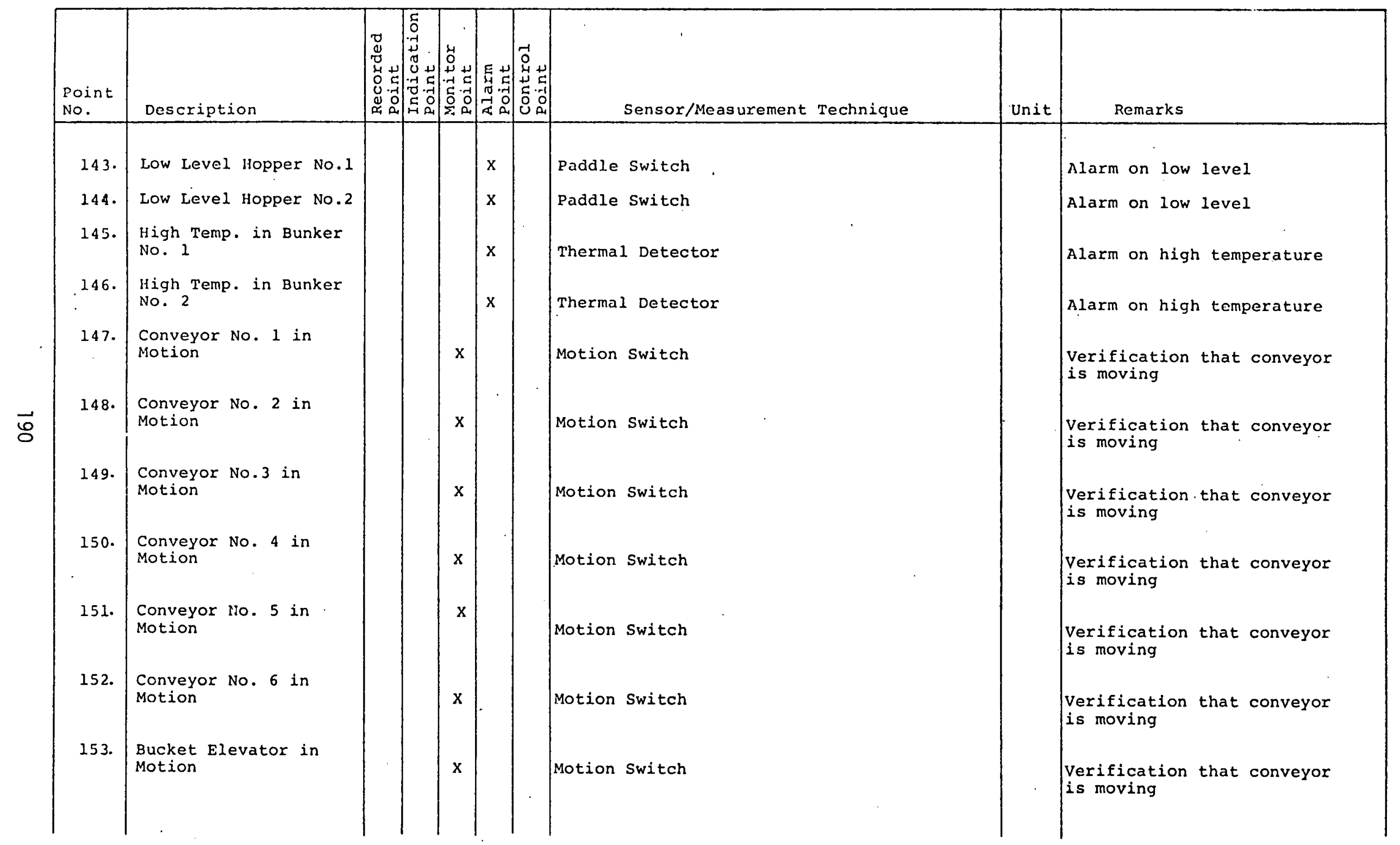




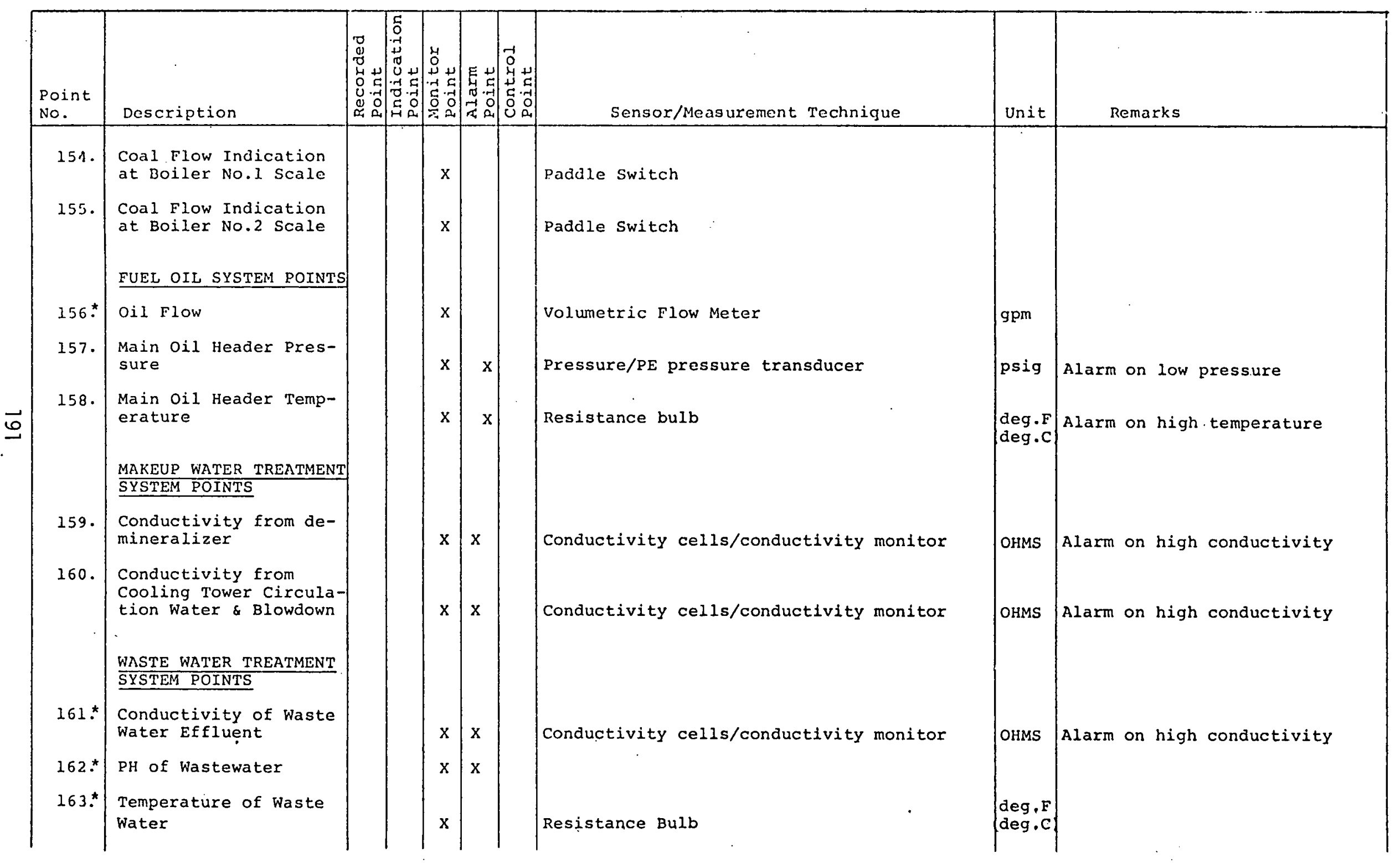




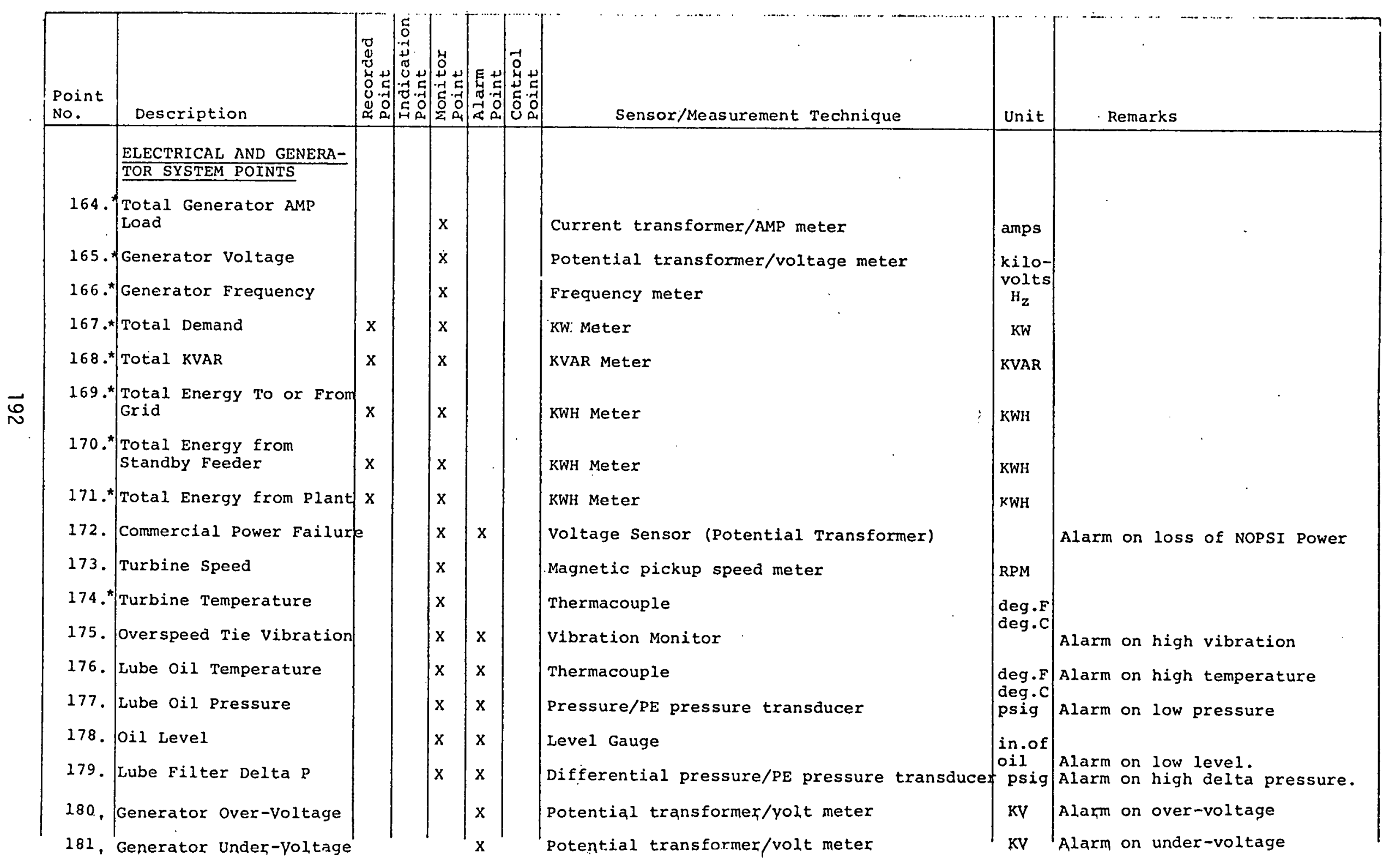




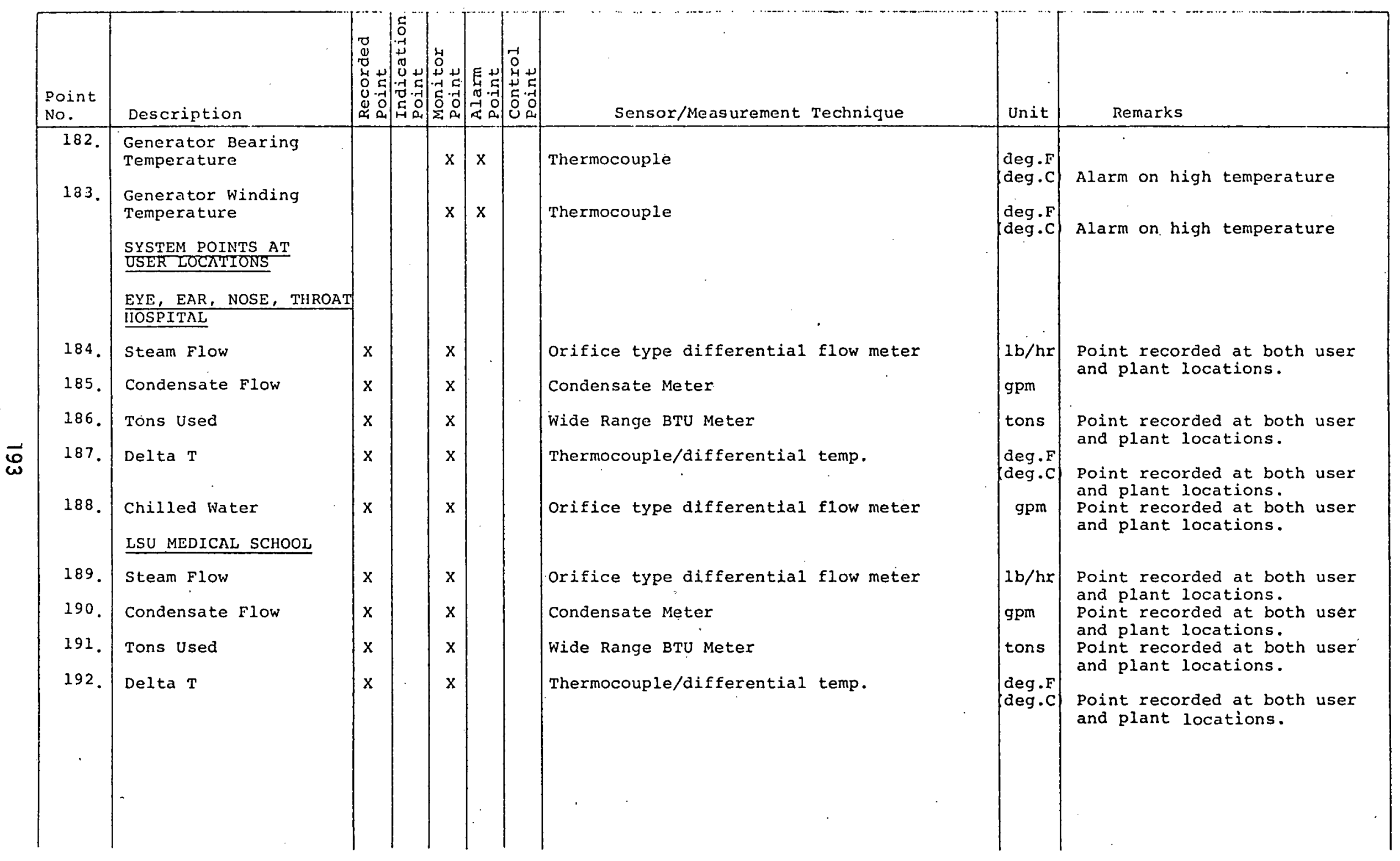




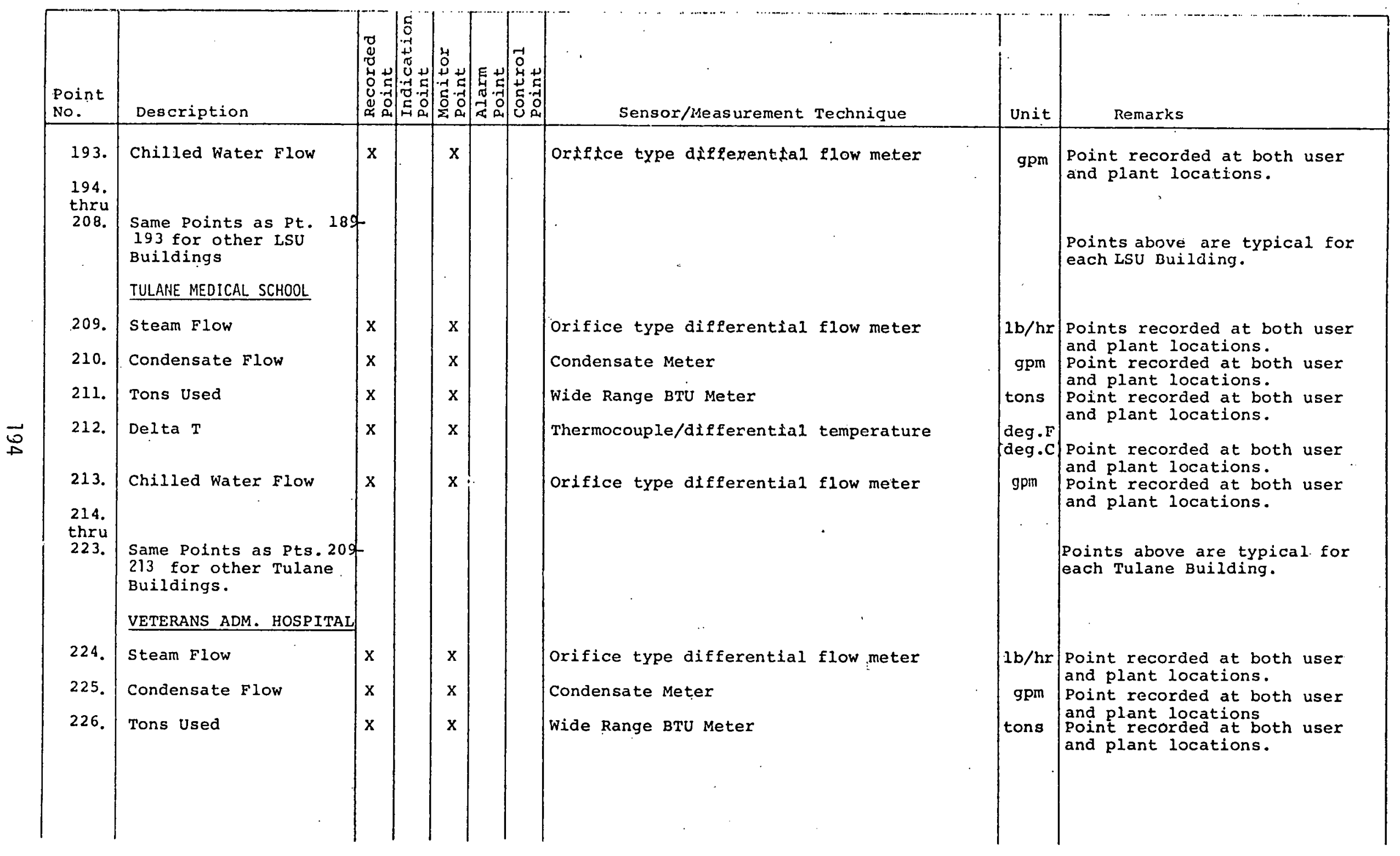




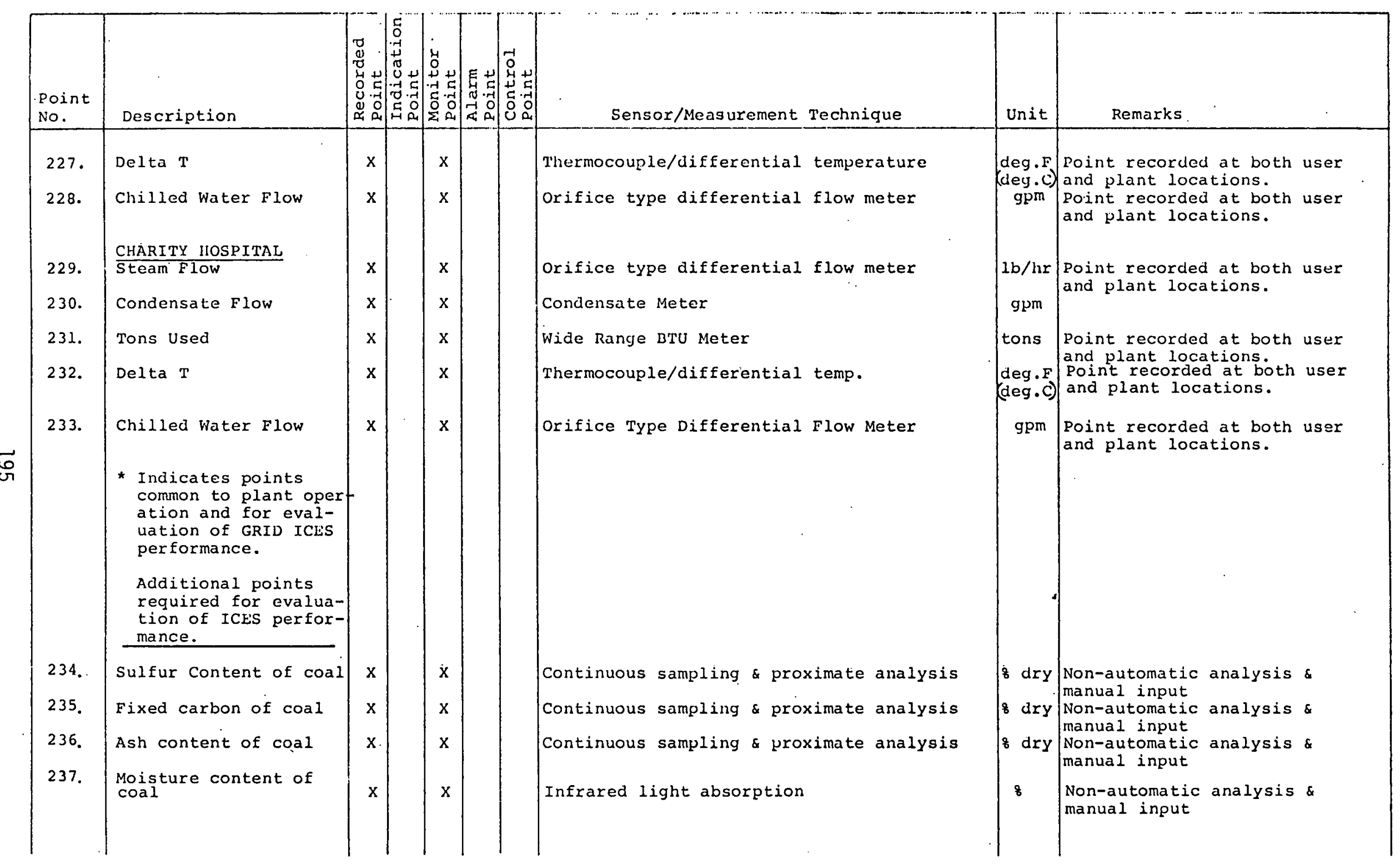




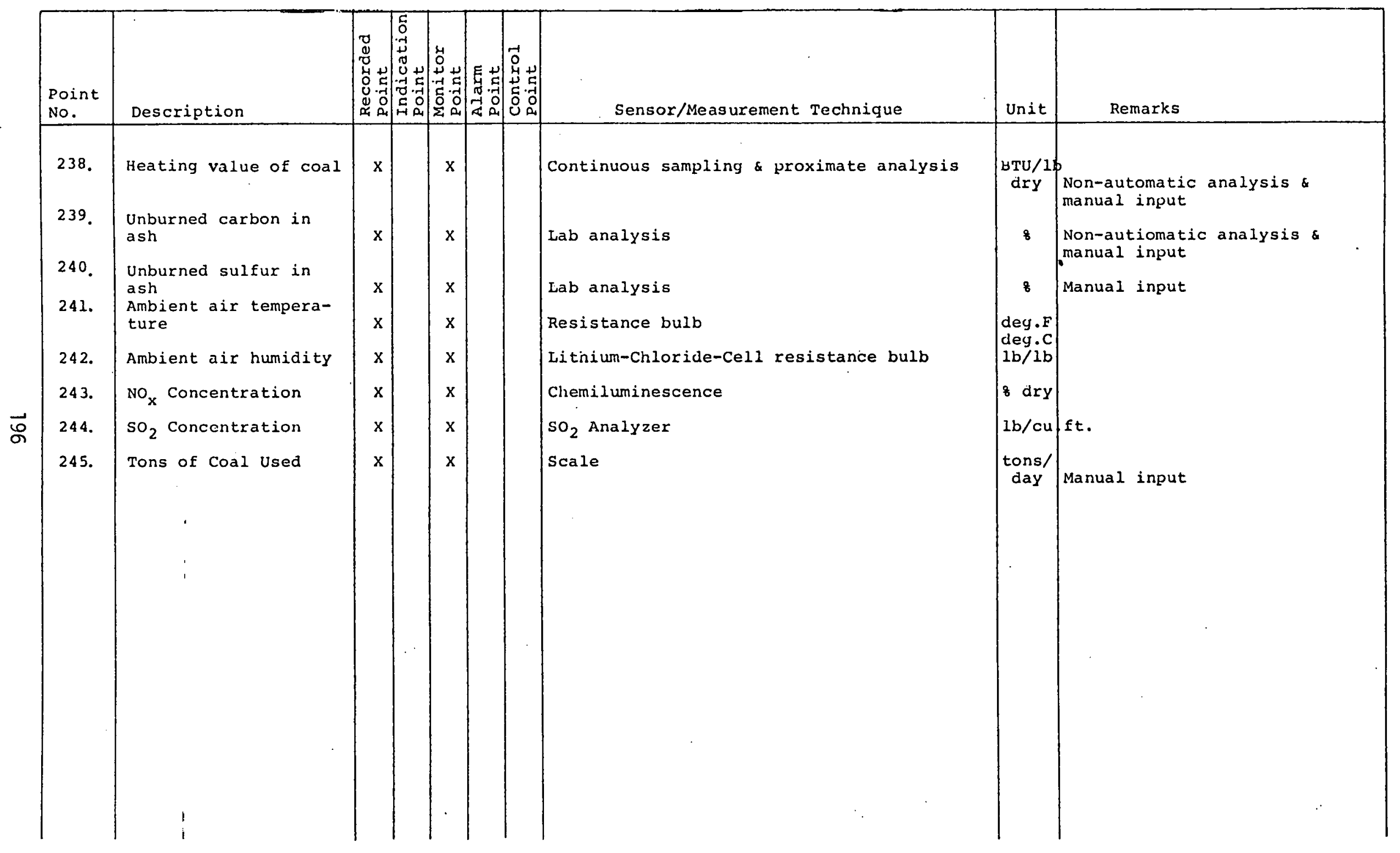




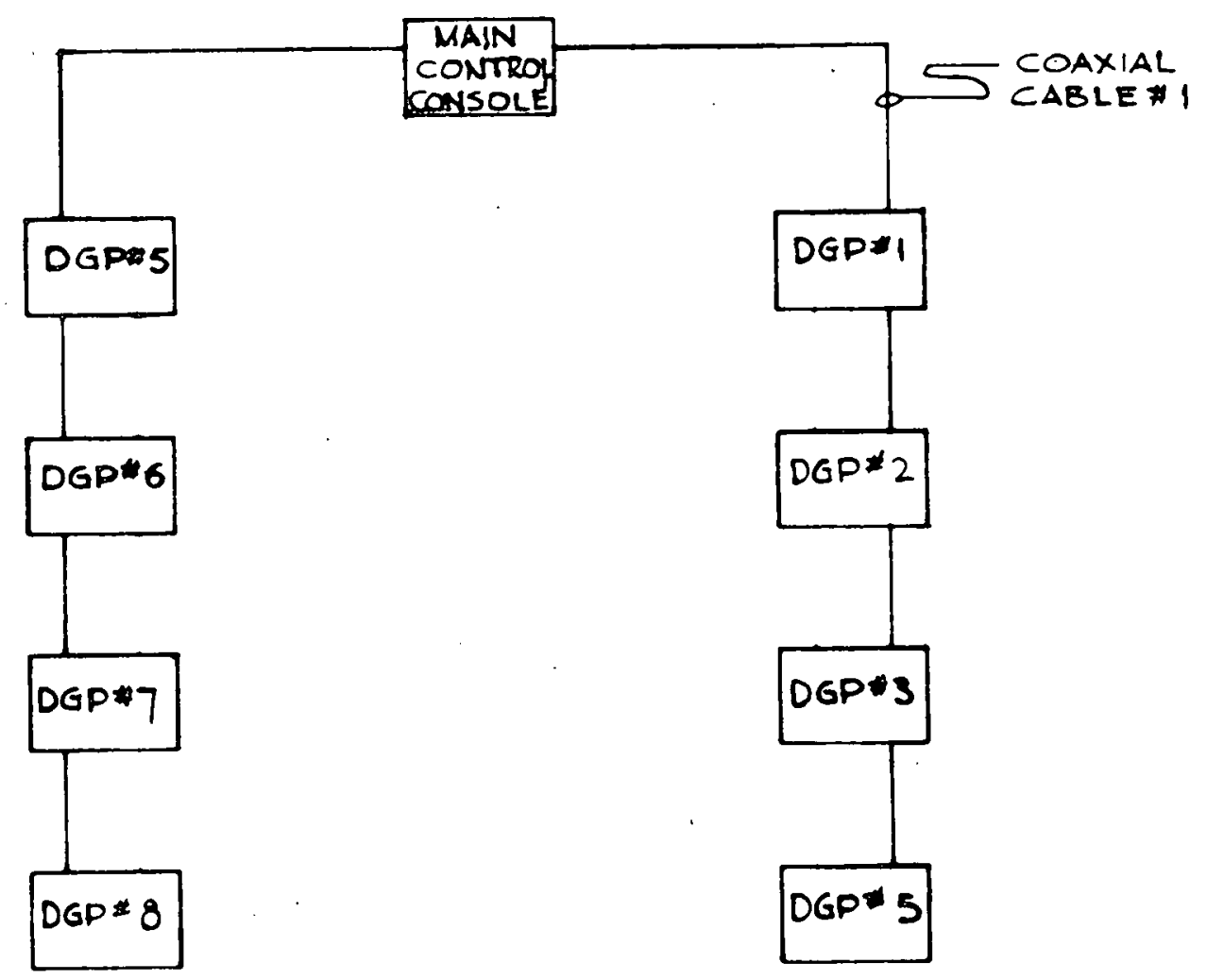

DATA SATHERING PANELS (IN PLANT)

1 - BOILER 1

2 - BOILER $\# 2$

3 - CHILLER $* 1$

$4-$ CHILLER $\approx 2$

5 - CHILLER 3

6 - COOLING TOWERS

7 - ELECTRICAL

8 - IN PLANT DISTRIBUTION POINTS

DIRECT DIGITAL CONTROL SYSTEM ONE LINE SCHEMATIC 


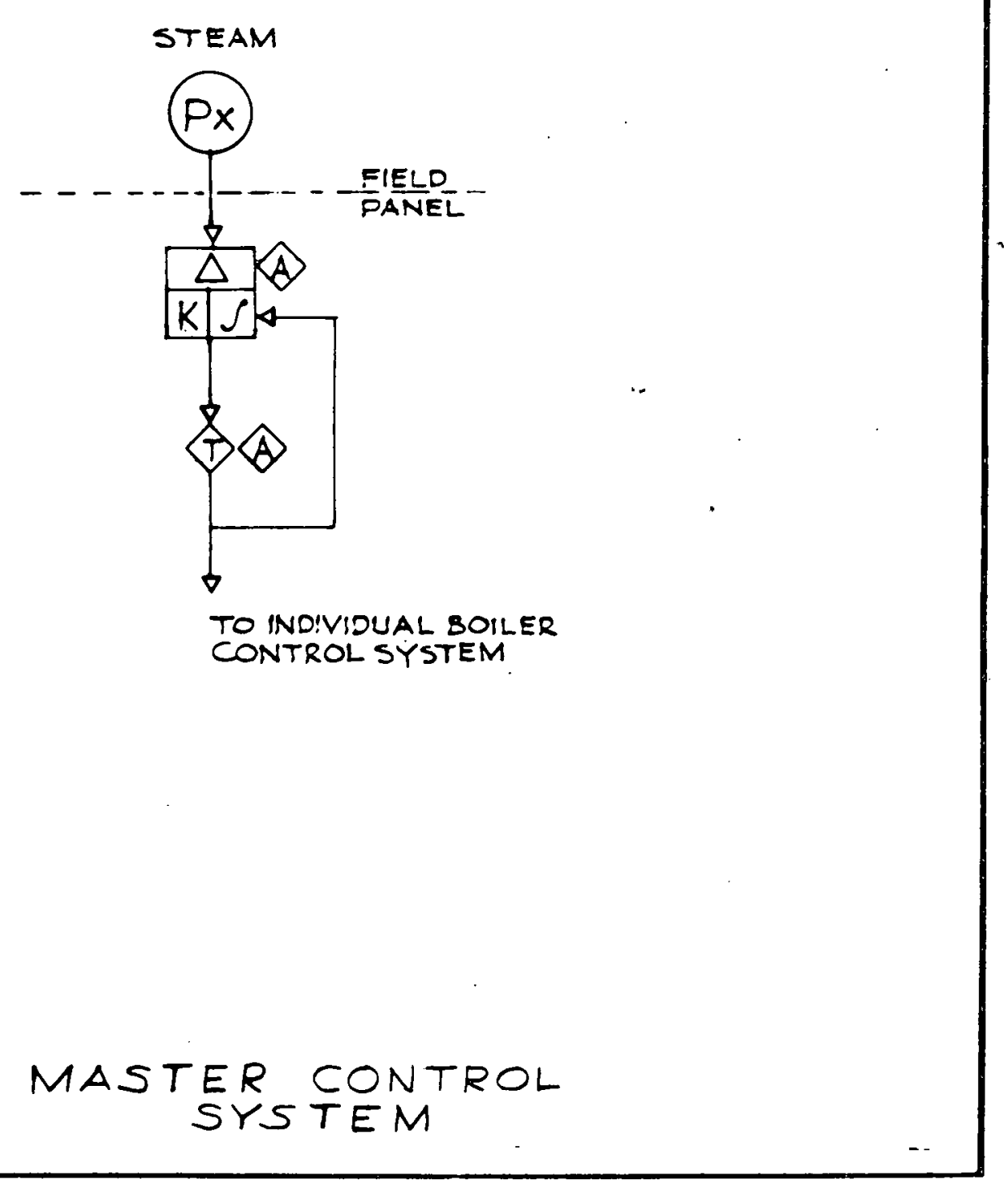

198 


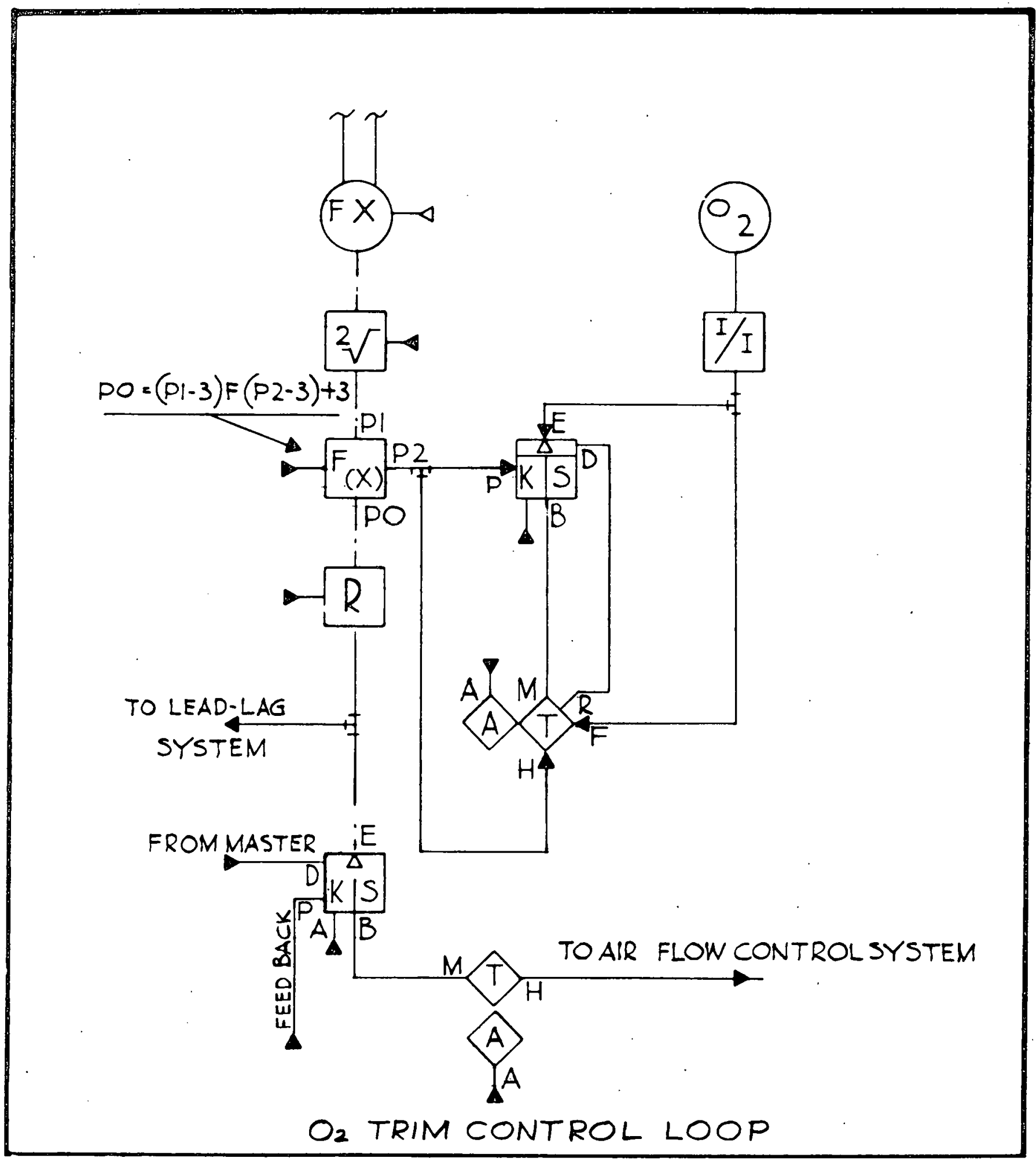




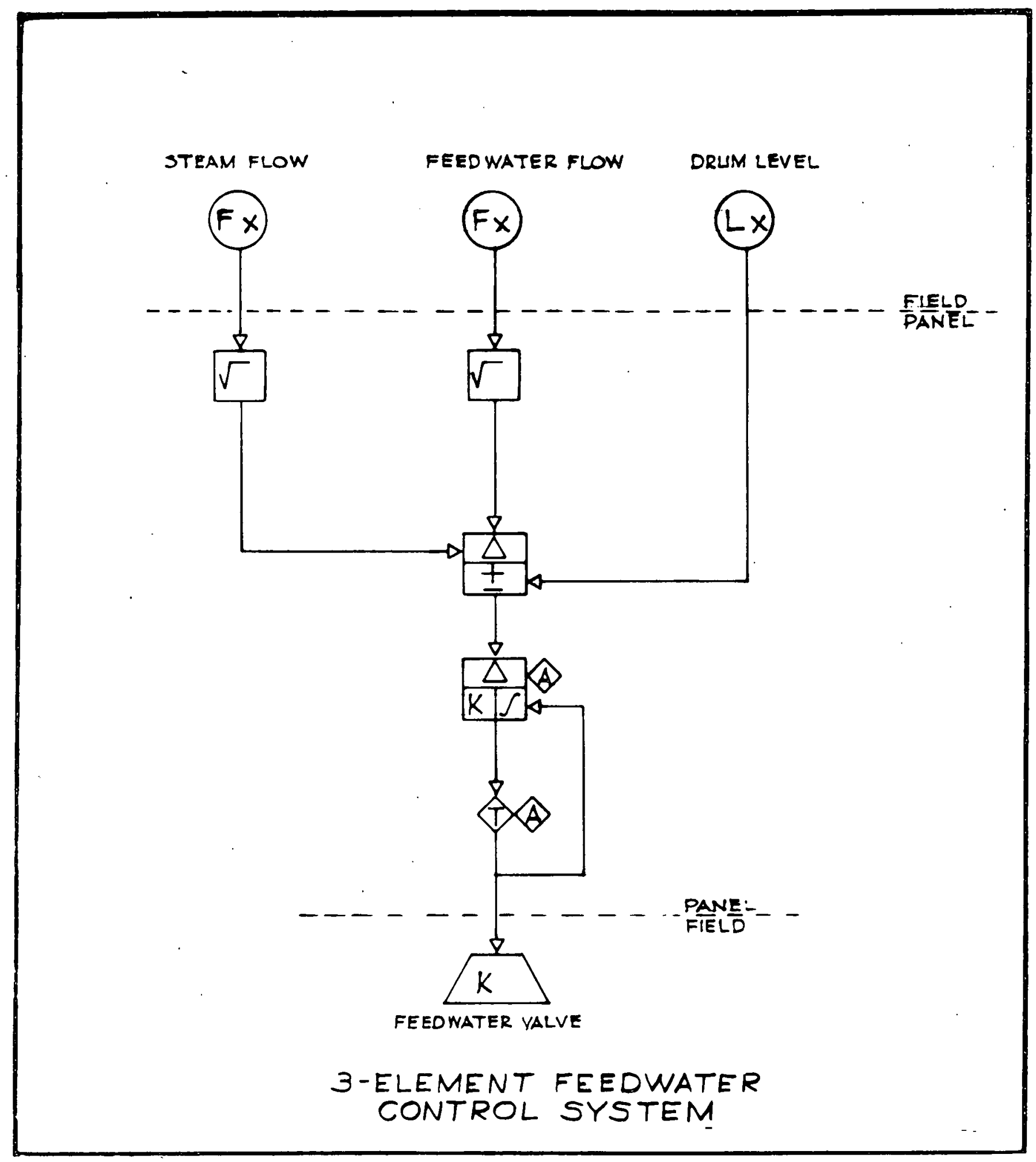




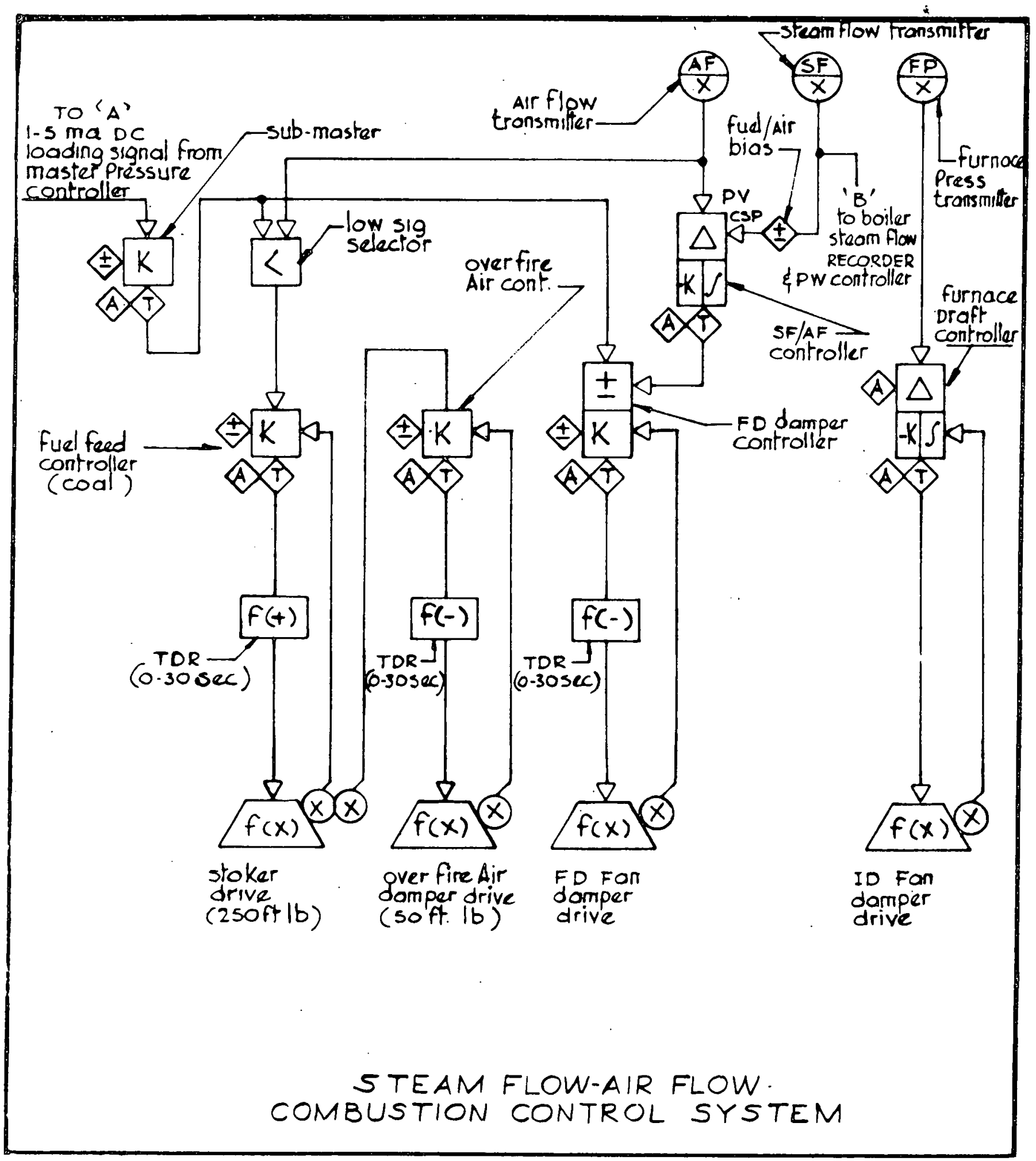




\section{LEGEND}

ENCLOSURR SMBOLS

\begin{abstract}
FUNCTION
MEASURTNG OR

RRADOUT

AUTOMATIC SIGNAL PROCBSSING
\end{abstract}

ENCLOSURB STMBOL.
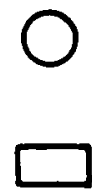

SIGAL PROCESSING SYMBOLS

SIGIAI PROCBSSING

SWyort
ENCLOSURB SYMBOL

SIGAI

PROCBSSING

FINAL CONTROLLING
FUNCTION

SUMMONG

AVERAGING

DIFFERENCE

PROPORTIONAL

REVERSE

PROPORTIONAL

INTEGRAI

DERIVATIVB

MULTIPIYING

DIVIDING

ROOT EXTRACTING

EXPONENTIAL

NONL INEAR OR

UNSPECIFIED FUNCTION

INDICATOR

TRANSKTITER

RRCORDER $\varepsilon$

$\varepsilon / n$

$\Delta$

K

$-k$

$\int$

$d / d t$

$x$

$\div$

$\sqrt{ }$

$x^{n}$

$f(x)$

I

$x$

$\mathbf{R}$
FUNCTION

TIMR FUNCTION

HIGH SELBCTING

LOW SELCTING

HIGH LIMTITNG

LOW LIMITING

VELOCITY L IMITER

BIAS

ANALOG SIGNAL

GENERATOR

TRANSFER

SIGNAL MONITOR

PRBSSURE

FLOW

LEVRI

TLMPERATURS
SIGAL PROCESSING SRBROT.

$f(t)$

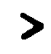

$<$

$\$$

$\Varangle$

V\$

$\pm$

A $T$

H/ OA H/L

P

F

L - -

$T$ 


\section{4.b.3.3 Outline Specifications - Electrical}

NOTE: These specifications are presented as "typical" only and are not to be considered as finalized or technically complete.

a) Transformers - Power, Substation Type 0il/Askarel Immersed, Rectangular Coil, Core Form, Type RSL

1) Scope and Basis of Specification

This specification calls for apparatus which will be designed, manufactured, and tested in accordance with the latest applicable NEMA and ANSI Standards and may be operated as out lined by any of these recognized Standards. ANSI C57.12.00 and Appendix C57.97 will apply except where specific requirements of these specifications shall take precedence.

2) Type and Rating.

KVA Rating _ Type Cooling Phase Hertz $55^{\circ} \mathrm{C}$ Average Copper Rise Voltages and Connections - (Specify Delta or Wye)

\begin{tabular}{|c|c|c|c|c|}
\hline Winding & $\begin{array}{l}\text { Rated Kva } \\
\text { and Con- } \\
\text { nection }\end{array}$ & $\frac{\text { BIL }}{\text { Line Neutral }}$ & $\begin{array}{l}\text { Taps } \\
\text { (Ind icate } \\
\text { RC or FC) }\end{array}$ & $\begin{array}{l}\text { Kva } \\
\text { Rating }\end{array}$ \\
\hline HV & & & & \\
\hline LV & & & & \\
\hline TV & & & & \\
\hline MV & & & & \\
\hline
\end{tabular}

Loading of this unit to be as follows: This transformer will be built incorporating thermally stabilized insulation to permit continuous operation at $65^{\circ} \mathrm{C}$ with $12 \%$ increase in capacity without loss of 1 ife expectancy.

Bushings, tap changers and all other parts of the transformer shall be made good for this higher rating. This $65^{\circ}$ rating shall be shown on the nameplate.

The transformer will be operated with the secondary winding (1) solidly grounded, or (as applicable), (2) ungrounded.

3) Auxiliary Cooling

Future Forced Air Rating - (OA/future FA).

Transformer will be designed with the current carrying capacity for the future addition of forced air cooling equipment. With this equipment in operation, the individual windings will have the capability of ___ increase in capacity.

When the transformer is operated as a self-cooled unit, without the forced air cooling in operation, a continuous load of 
Kva may be carried, without exceeding an average temperature rise of $55^{\circ} \mathrm{C}, 65^{\circ} \mathrm{C}$ hotspot.

4) Impedance

The impedance of the transformer at normal rating will be approximately percent at Paralleling is required. to volts and Kva.

5) Guide for Loading

Transformer may be loaded in excess of its normal rating under variable conditions such as low ambient, low load factor, short time overloads, etc., as determined from the ANSI "Guide for Loading 0i1-Immersed Distribution and Power Transformers".

6) Quality Control Testing

Transformers will be subjected to routine quality control tests to check the adequacy of design, materials, workmanship, and processing.

7) Sound Leve1

When energized at normal. voltage and frequency and at no load, the average sound level of the transformer will not exceed the following, when measured in accordance with NEMA audible sound level test procedure.

Average Sound Level: Decibels KVA

62

2,500

68

7,500

70

10,000

A11 Kva ratings on $O A$ basis.

8) Provision for Current Transformers

Provision will be made for the future installation of current transformers inside the main case. A cover opening will be supplied large enough to permit admittance of bushing type current transformers. Mounting details and lead junction boxes will be furnished with the main transformer. Current transformers may be added later as follows:

\begin{tabular}{l|l|l|l} 
Circuit & Type & Ratio & Number \\
\hline HV & & & \\
\hline LV & & & \\
\hline TV & & & \\
\hline
\end{tabular}


9) Tap Changer

A hand operated tap changer will be provided to permit changing connections in the HV winding from outside of the case. This tap changer is intended for operation only when the transformer is not energized.

The operating mechanism will be located on the tank wall at a height and location suitable to the requirements of the design. Provision will be made for padlocking the operating mechanism in any position.

10) Terminal Board

A terminal board and the necessary connectors for obtaining (a) delta or Wye, (b) series or multiple connections of the high or low voltage windings will be supplied.

Connections may be changed through handholes or manholes with removable covers.

11) 0 il Preservation

0il preservation equipment shall be provided.

12) Pressure Relay

A sudden pressure relay for fault detection will be provided and mounted in the gas space above the oil level.

The manual reset circuit will be suitable for operation at volts (A.C.) (D.C.).

13) Bushings

The transformer bushings will have voltage ratings as follows:

\begin{tabular}{l|l} 
Winding & Bushing KV Rating \\
\hline HV Line & \\
\hline HV Neutral & \\
\hline LV Line & \\
\hline LV Neutral & \\
\hline TV Line & \\
\hline
\end{tabular}

These will be ASA Standard businings where applicable.

14) Terminal Chamber

High or low voltage cables are to be brought through (wiping sleeve), (pothead), (stuffing box), (conduit connection) type of terminal into and (oil), (air) filled housing which will be mounted on the wall of the transformer case. The cables will enter vertically into the (top), (bottom) of the chamber. 
Cable information as follows:

15) Load Indicating Thermal Relay Equipment

Winding hot spot thermal relay equipment will be supplied in one phase of the winding (s).

16) Dial Type Thermometer for Hot 0 il

A dial type thermometer with alarm contacts will be provided to indicate the temperature of the hottest insulating liquid. The dial will be located on the tank wall at a height convenient to the design.

17) Liquid Level Gauge

A magnetic type gauge with low level alarm contacts will be provided to indicate continuously the level of the insulating liquid. A separate oil gauge will be provided for each $0 i 1$ filter compartment.

18) Standard Electrical Tests

The following Standard Electrical Tests will be made.

Resistance measurement of all windings at rated voltage connection on all units and (on one unit only of the order) at the tap extremes of all windings.

Ratio tests at rated voltage and all tap connections.

Polarity and phase relation at rated voltage connection.

No load loss and exciting current at rated voltage.

Impedance and load loss at rated current on the rated voltage connection on one unit only. Impedance and load loss measurements will be made between the extreme tap positions of each pair of windings.

When the transformer has auxiliary cooling and is given more than one nameplate rating and the temperature $r$ ise is guaranteed at each rating, an additional temperature test will be made to demonstrate each guarantee.

Applied potential tests.

Induced potential test. 
INSULATION LEVEL APPLICATION

\begin{tabular}{|c|c|c|c|c|c|c|}
\hline $\begin{array}{l}\text { Nominal } \\
\text { System }\end{array}$ & $\begin{array}{l}\text { Basic } \\
\text { Impul.se }\end{array}$ & $\begin{array}{l}\text { Low } \\
\text { Frequency }\end{array}$ & $\begin{array}{l}\text { Chop } \\
\text { Impi }\end{array}$ & $\begin{array}{l}\text { Wave } \\
\text { Test }\end{array}$ & $\begin{array}{l}\text { Line } \\
\text { Bushings }\end{array}$ & $\begin{array}{l}\text { Phase- } \\
\text { to- }\end{array}$ \\
\hline voltage: & $\begin{array}{l}\text { Level: } \\
\text { Kv }\end{array}$ & $\begin{array}{l}\text { Test to } \\
\text { Ground: } \\
\text { Kv }\end{array}$ & $\mathrm{kV}$ & $\begin{array}{l}\text { Minimum } \\
\text { Time to } \\
\text { Flashover: } \\
\text { Ms }\end{array}$ & $\begin{array}{l}\text { Kv Voltage } \\
\text { Class }\end{array}$ & $\begin{array}{l}\text { Pr: :e } \\
\text { Test: } \\
\text { Kv }\end{array}$ \\
\hline
\end{tabular}

Liquid Immersed

\begin{tabular}{l|r|r|r|r|r|r}
\hline 5.0 & 75 & 19 & 88 & 1.6 & 5 & (1) \\
15 & 110 & 34 & 130 & 2.0 & 15 & (1) \\
150 & 50 & 175 & 3.0 & 23 & (1) \\
\hline
\end{tabular}

(1) Induced phase-to-phase test will be 2 times normal operating voltage.

(2) Maximum operating voltage not to exceed $105 \%$ of nominal system voltage.

19) Lightning Arresters

Station type lightning arresters will be supplied as follows: (if applicable)

\begin{tabular}{l|l|l|l} 
Circuit. & $\begin{array}{l}\text { Number } \\
\text { Arresters }\end{array}$ & $\begin{array}{l}\text { Type } \\
\text { (Station } \\
\text { or line } \\
\text { type) }\end{array}$ & $\begin{array}{l}\text { Kv } \\
\text { Rating }\end{array}$ \\
\hline HV Line & & & \\
\hline HV Neutral & & & \\
\hline LV Line & & & \\
\hline LV Neutral & & & \\
\hline TV Line & & & \\
\hline
\end{tabular}

The arresters will be mounted on supports attached to the transformer.

20) Insulating Liquid

Transformer to be shipped with the required amound of liquid installed. 
21) Field Assembly

Transformers will be shipped as complete as possible consistent with average shipping limitations and protection to the equipment.

b) Metal Clad Switchgear - Medium Voltage

1) General

The metal-clad switchgear described in this specification will be an assembly of breaker housings, auxiliary housings, and horizontal drawout circuit breakers arranged to suit the specific requirements of the system. It will be of indoor construction and will be rated 4.76 and $15 \mathrm{kv}$. It will be for use on the 4160 and 13,800 volt, 3 phase, 60 Hertz systems. The switchgear will be designed, manufactured and tested in accordance with the latest standards of ANSI and NEMA.

The breaker housings and auxiliary housings will be bolted to each other to form a rigid metal enclosed switchgear assembly. Each housing will consist of functional components or modules. They will be the breaker/bus, control, and line modules and, if required, an upper rear module. Metal side pans will provide a double thickness of steel between adjacent housings and metal barriers will isolate the primary major sections of each circuit. Removable metal barriers will provide access to the primary major sections of each circuit. Rear covers will be bolted-on sheets.

2) Panels: Indoor

An upper and lower formed hinged panel will enclose the breaker drawout side of each housing. The upper panel will be used for control devices, relays, meters, and instruments. The lower panel will cover the circuit breaker portion of the housing and will have an access port to permit levering the breaker between the operating and test positions with the panel closed. When necessary a front extension and full height formed hinged panel without an access port will be used. All units will have front panels that can be closed for any position of the breaker element to form a continuous line.

\section{3) Breaker/Bus Module}

The main bus will be of aluminum and will have flame retardant insulation. Porcelain ma in bus supports will cover the bus opening between housings to provide a non-combustible fire wall. Bus joints shall be provided in each unit. All bus joints will be silver-plated, bolted, and insulated with boots secured by nylon hardware. The stationary primary contacts wil. be silver plated and recessed within porcelain supports. An automatic shutter will cover the stationary primary disconnecting contacts when the breaker is in the disconnected position or out of the housing with full air clearance to live parts. The stationary secondary contacts will be silver-plated multiple sockets. A stationary guide rail, levering-in screw, and safety interlocks will be provided to function with the circuit breaker. A ground 
contact will ground the breaker between and including the operating and test positions. Breaker/bus modules of the same rating will be interchangeable and will house any circuit breaker of the same rating.

4) Control Module

A set of terminal blocks will be provided for secondary connections to external circuits. A control circuit cutout device will be provided in each circuit breaker housing. Switchgear secondary wire will be \#14 AWG minimum.

5) Line Module

The ground bus will be of aluminum and will extend the length of. the switchgear assembiy. The ground bus joints will be silverplated and will be bolted to each housing and to each breaker ground contact. A clamp-type terminal will be furnished for terminating a ground cable. Clamp-type terminals or potheads will be furnished for terminating power cables entering from top or bottom.

6) Instrumeni Transformers

Ring-type current transformers will be furnished with ratios as indicated in the detail specifications. Their thermal and mechanical ratings will be coordinated with the circuit breakers. Their accuracy ratings will be at least equal to NEMA Standard requirements.

The standard location for at least one ring type current transformer per phase on the bus side and line side of 1200 to 2000 ampere breaker units will be front accessible to permit adding or changing current transformers without removing high voltage insulated connections.

Potential transformers will be furnished with ratios as indicated in the detail specifications. They will be of the disconnecttype and will be equipped with current limiting fuses.

7) Finish

Steel will be cleaned and phosphatized. The final indoor finish will be light grey ASA \#61. The final outdoor finish will be dark grey ASA \#24, applied over a coat of 1ight grey paint. An undercoating compound will be applied to outdoor switchgear.

8) Circuit Breaker

The circuit breakers wi 11 be horizontal drawout type, standard momentary type, rated 1200 or $2000,4.16 \mathrm{Kv}, 3$ phase, 60 Hertz. The breakers will be operated by a motor-charged, spring-type, stored-energy mechanism. The stored energy mechanism will be charged normally by a universal electric motor and in an emergency by a manual handle. The primary contacts will be silver-plated and supported by porcelain pole units. Primary disconnecting fingers will be silver-plated; contact pressure will be maintained with leaf springs. Hinged tilting arc chutes with center 
coil blowout magnets will be provided. A vertical metal barrier in front of the arc chutes will form a shield from primary parts.

The secondary disconnecting contacts will be silver-plated multiple plugs of the train-line coupler type. The plugs will automatically engage the housing sockets in the breaker operating position and manually in the breaker test position. A guide channel will provide lateral alignment with the housing guide rail. Interlocks will be provided to prevent levering of a closed breaker, to prevent closing of a breaker between operating and test positions, to trip breakers upon insertion or removal from housing, and to discharge stored energy mechanisms upon insertion or removal from the housing.

The breaker will be secured positively in the housing between and including the operating and test positions. Circuit breakers of the same rating will be interchangeable and will fit any housing of the same rating.

c) Low Voltage Control Centers

These specifications cover NEMA Class I and II, Types B and C motor control centers in NEMA Type 1. The motor control centers shall be manufactured to conform to Underwriters' Laboratories Standard No. 845, and appropriateily U/L labeled where possible.

The control centers will be supplied from a 480 volt, 3 phase, 4 wire, 60 Hertz power system having a short-circuit capacity of $(x)$ amperes rms symmetrical at the control-center terminals.

Incoming power feeder shall be cable entering at top of the left hand section and terminated on a main protective device.

Main protective device shall be a molded case circuit breaker of the required amperage for bus protection.

Power shall be distributed by means of a continuous horizontal bus with a rating of the indicated amperes. The bus shall be braced for 42,000 amperes rms symmetrical.

Combination motor controller and feeder top units shall employ moldedcase circuit breakers for branch circuit protection of the indicated interrupting capacity.

Combination motor controller units shall be equipped with individual control power transformers with one secondary control fuse. The other secondary lead shall be grounded control voltage shall be 120 VAC.

Starter units shall contain auxiliary contacts, unit-mounted pilot devices and indicating lights, control relays and other devices as ind icated.

Other units to be included in the motor control centers as indicated are lighting and power transformers, lighting distribution pane 1board, and metering panels and instrument transformers. 
The control centers shall consist of 3 or more vertical sections bolted together to form a unit assembly. A removable lifting angle shall be provided for the assembly. Two removable floor sills shall be provided for mounting.

Wireway compartments for horizontal wiring shall be provided at the top and bottom of the control center. Incoming-line compartment shall be front accessible. A vertical wiring compartment witi, separate hinged front door shall be provided in each controller section.

Each unit compartment shall be provided with an individual front door. Starters and feeder-unit doors shall be interlocked mechanically with the unit disconnect device to prevent unintentional opening of the door while energized and unintentional application of power while door is open. Means shall be provided for releasing the interlock for intentional access to the interior at any time and intentional application of power, if desired, while door is open. Padlocking arrangements shall permit locking the disconnect service OFF with at least three padlocks with door closed or open. Unit disconnect operating handle shall be mounted on the disconnect, not on the unit door and shall indicate ON and OFF with door open or closed. Means shall be provided for padlocking the unit in the partially withdrawn position. Overload relays shall be reset from outside the enclosure by means of an insulated bar or button. "Test" feature allows for complete testing of individual units or testing continuity of control circuitry without energizing motors.

Stab-in starter units up to 48 inches high shall be full drawout and shall not be able to be inserted or withdrawn unless the unit disconnect is OPEN. Units can be withdrawn without disconnecting any wiring. Units over three space units high may be bolt-in type. A positive guidance system shall be provided to assure proper al ignment of wedge-shaped power stabs in dead-front openings in vertical power bus. A shutter mechanism shall be furnished to cover stab holes when unit is removed. The screw racking mechanism shall serve as a mechanical advantage to the operator during unit insertion or removal. Stab-in power terminals sha11 be of a type that will increase contact pressure on short circuits. Bolt-in starter units, sizes 5,6 and 7 , shall be of closed-door construction such that the unit cannot be opened until power is disconnected from the vertical bus to the line side of the unit disconnect.

The horizontal power bus shall be effectively isolated from all wiring troughs and other working areas. Vertical bus extensions shall be isolated by means of rigid glass polyester moldings in such a manner as to be a separate self-supported assembly. No extra safety jacks or similar devices shall be required to obtain an essentially deadfront condition. Access shall be provided for inspection and maintenance from the front. All bus barriers shall be white for increased visibility.

Motor control centers shall be furnished in 1 ineups nominally 90 inches high and in multiples of 20 inches wide. Depth shall be 20 inches.

Units shall be front mounted only.

Phase relationship of stab-in terminals for back-mounted starter and feeder units shall be the same as for front-mounted units. 
d) Medium Voltage Motor Control

1) General

These specifications cover NEMA Class E2 medium-voltage control for 4160 volt, 3 phase, 60 Hertz motors as follows:

Controllers shall be full voltage, non-reversing and shall be fused type employing current-limiting power fuses that give the controller an interrupting capacity of 360,000 kva 3-phase, symmetrical at 4000 volts, $50 / 60 \mathrm{Hertz}$. Starters shall employ magnetic air-break line contactors rated 400 amp, 5000 volts and have an interrupting capacity of 50,000 kva, 3-phase, symmetrical.

Controllers shall be in two-high construction with NEMA Type 1 ventilated enclosure and with three-phase, 2000-amp, a-c power bus. Enclosures shall be compartmented into low-voltage control compartment with separate door, high-voltage control compartment with separate door, a-c bus compartment and cable-entrance compartment.

Line contactors shall be drawout type.

The controller shall be isolated by externally operated drawout stabs with shutter mechanism. The isolating device shall also open the secondary of the control power transformer. Interlocks shall be provided to prevent (1) inadvertent operation of the isolating mechanism under load, (2) opening the medium-voltage compartment door without isolating the starter and (3) closing the line contactor with door open.

For overload protection, ambient-compensated thermal overload relays, hand-reset and ground-fault protection shall be included in three phases.

Control power at 115/230 volts shall be provided from a controlpower transformer in each controller. Transformer shall be protected by current limiting fuses.

Controllers shall provide instantaneous undervoltage protection when momentary-contact pushbutton is used, undervoltage release when maintained-contact switch is used.

Finish shall be ASA-61 gray over rust-resistant phosphate undercoat for indoor use or ASA-61 gray enamel over one or more rustresistant undercoats for outdoor use. 


\section{4.b.3.4 OUTLINE SPECIFICATIONS - MECHANICAL}

a) Refrigeration Units

Furnish and install three (3) 5000-ton refrigeration machines. Machines shall be driven by multistage steam turbines with inlet conditions of $185 \mathrm{psig}$ and $475^{\circ} \mathrm{F}$ with a steam rate of not more than 9 pounds per tor. Evaporators shall be selected to pass $8000 \mathrm{gpm}$ of chilled water, with $55^{\circ} \mathrm{F}$ entering temperature and $40^{\circ} \mathrm{F}$ leaving temperature. Refrigerant condensers shall be sized on the basis of $150,000 \mathrm{gpm}$ condensing water with $85^{\circ} \mathrm{F}$ entering temperature and $95^{\circ} \mathrm{F}$ leaving temperature.

Steam condenser shall be sized to condense 45,000 pounds of steam per hour, based on condensing water flow of $15,000 \mathrm{gpm}$ entering at $95^{\circ} \mathrm{F}$ and leaving at $105^{\circ} \mathrm{F}$.

Units shall be complete with condenser hot well pumps and recirculating system.

b) Chilled Water and Condenser Water Pumps

Furnish and install 3 each chilled water and condenser water pumps. Pumps shall be double suction, enclosed impeller, bronze fitted.

Each chilled water pump shall have a capacity of 8,000 gpm at a T.D.H. of 160 feet, driven by a 400 HP, 1180 RPM motor, open, drip proof 4160 volts, 3 phase, 60 Hertz.

Each condenser water pump shall have a capacity of 15,000 gpm at a T.D.H. of 85 feet, driven by a $400 \mathrm{HP}, 710$ RPM motor, open, drip proof 4160 volts, 3 phase, 60 Hertz.

c) Cooling Tower

Furnish and install one counterflow cooling tower made up of four cells. Tower shall have a capacity of $45,000 \mathrm{gpm}, 86^{\circ} \mathrm{F}$ $106^{\circ} \mathrm{F}$ at $80^{\circ} \mathrm{F}$ wet bulb. Each cell shall be equipped with two fans, complete with motor drive and gear reducer; motors shall be rated at $125 \mathrm{HP}, 480$ volt, 3 phase, 60 Hertz.

d) Boilers

Furnish and install two boilers complete, each having a nominal rating of 200,000 pounds of steam per hour, with steam conditions at the outlet of $1250 \mathrm{psig}$ and $950^{\circ} \mathrm{F}$. The boilers shall be of the bal anced-draft, spreader-stoker firing type, with travelling grate, and capable of burning natural gas, fuel oil, coal and a combination of coal and processed refuse. The boilers shall be provided with economizers and dust collectors.

Two forced draft fans shall be provided complete with motors and inlet control vanes. Steam-air heaters shall be provided at the 
outlet of these fans.

A1) ductwork and breeching from the forced draft fan inlets complete through the boiler, scrubber, induced draft fans and to the stack shall be provided.

e) Flue Gas Scrubbers

Furnish and install a flue gas scrubber for each boiler, capable of treating approximately 125,000 ACFM of flue gas at $575^{\circ} \mathrm{F}$. The scrubbers shall remove particulate and sulphur dioxide to residual values that will comply with the then existing allowable emission standards. The scrubbers will use a sodium carbonate slurry as the scrubbing agent. The particulate and sulphur dioxide being drawn off in slurry and through a series of recycling pumps and tanks, clarifiers, etc., will be deposited eventually as a sludge in the waste treatment storage tanks.

f) Induced Draft Fans \& Drives

Furnish and install at the outlet of each scrubber a stainless steel type 316 fan capable of withstanding a saturated flue gas atmosphere, and handling approximately 95,000 ACFM at $145^{\circ} \mathrm{F}$. Each fan shall be capable of producing 23 to $25^{\prime \prime}$ of static, requiring 750 horsepower motors.

g) Boiler Feed Pumps and Drives

Boiler feed pumps shall be multi-stage, split-case pumps, carbon steel, rated $410 \mathrm{gpm}$ and $210 \mathrm{gpm}$ with a T.D.H. of $3200 \mathrm{ft}$. The large pump shall be equipped with a $500 \mathrm{HP}$ turbine drive, and the two smaller pumps with $350 \mathrm{HP}$ electric motor drives. Pump speeds shall be 3550 RPM.

h) Deaerator

Furnish and install a deaerator designed to heat 350,000 pounds per hour of condensate from $145^{\circ} \mathrm{F}$ to $250^{\circ} \mathrm{F}$. The steam supply will be the exhaust from the boiler feed pump turbine, and/or steam from the 185 pound header reduced to $15 \mathrm{psig.} \mathrm{The} \mathrm{storage} \mathrm{section} \mathrm{shall} \mathrm{be}$ capable of accommodating 5000 gallons.

\section{i) Steam-Turbine Generator}

Furnish and install one (1) $9500 \mathrm{KW}$ non-condensing steam turbine with inlet conditions of $1250 \mathrm{psig}$ and $950^{\circ} \mathrm{F}$, exhausting at 185 psig, connected to a 11,175 KVA generator rated at 0.85 power factor, 13,800 volts and 0.58 short circuit ratio, 3600 RPM.

Unit shall be of the horizontal split case design with integral down exhaust opening, with flanged outlet and alloy steel casing construction suitable for pressure/temperature rating specified.

The unit shall be provided with steel chest complete with 
multiple automatic speed control valves for optimum part-load performance. The valves shall be of the single-seated type, lifting bar or cam operated in order to be operated in proper sequence. The turbine shall be equipped with a synchronous turbine generator steam control system, hydraulically operated, with control pilot servo system. The regulation shall be $4 \%$ aiiu adjustable from $3 \%$ to $6 \%$. The speed control range shall be adjustable from $95 \%$ to $105 \%$ of rated speed. The multi-stage rotor shall consist of an alloy steel forged shaft, with each individual wheel forged, machined and shrunk-keyed to the shaft. The entire rotor assembly shall be dynamically balanced.

The turbine shall be equipped with a shaft driven lubricating oil pump, as well as an auxiliary steam driven pump as part of the lubrication system.

The generator shall be 2-pole, 3600 RPM, direct connected to the turbine shaft through an integral coupling. The generator shall be equipped with a shaft-mounted excitor and shall be air-cooled design. The voltage and frequency regulator shall be consistent with the NOPSI grid requirements and standards. The entire turbine generator unit shall comply with ANSI codes and IEEE and NEMA standards.

\section{j) Coal Handling System}

A 50 ton per hour coal handling facility shall be furnished and installed and shall include the following equipment:

\section{1) Truck Hopper}

The truck hopper shall have a capacity of 25 tons, shall be constructed of steel lined with $3 / 16^{\prime \prime}$ stainless steel on al1 wearing surfaces, and shall be complete with totally enclosed gate. Hopper shall be sloped. not less than $60^{\circ}$ from the horizontal.

The coal bunker shall be of standard steel design, suspendedtype, equipped with 14 discharge gates.

\section{2) Under-Hopper Conveyor}

Furnish and install a belt feeder, 24 inches wide $\times 25$ feet centers, capacity 50 tons per hour of western Montana coal, complete with $10 \mathrm{HP}$ motor, $1800 \mathrm{RPM}, 460$ volt, 60 Hertz, 3 phase TEFC. Speed reducer will be shaft mounted on the feeder head shaft and driven from the motor by $V$-belt and sheaves, protected by steel plate guard. The feeder shall be complete with heavy duty belt, single roll idlers, frame and supports, discharge hopper and hood, skirts, belt wiper, and slider bed.

3) Magnetic Separator

Furnish and install one in-line magnetic separator over the head end of the belt conveyor that will discharge tramp iron in 
the same direction as the belt travel.

The cleaning belt conveyor will be equipped with cleats, driven by a 3 HP TEFC, 1800 RPM, 460 volt, 60 Hertz, 3 phase motor with reducer sprocket, chain and steel plate guard.

Magnet shall be suitable size for the 'conveyor, electromagnetic type, complete with selenium rectifier. Unit shall be complete with frame and supports, hopper and chutes.

4) Coal Crusher

Furnish and install one rolling ring type crusher with a capacity of 55 tons per hour and capable of reducing maximum of 6" lump western coal to spreader stoker coal size. Crusher shall be constructed of heavy cast iron, ribbed for added strength and sectionally built for easy access to the grinding parts. The entire crushing chamber shall have sectional liners; all crushing parts shall be manganese steel. An external adjustable drop bottom screen will be provided for varying product size and to compensate for wear.

Unit shall be complete with 30 HP motor, 460 volt, 3 phase, 60 Hertz squirrel cage, normal torque, direct connected to the crusher shaft through a flexible coupling. Furnish necessary heavy duty structural steel frame for support. Provide metal guard over the coupling and flywheel. Provide integral bypass chute.

5) Crusher Conveyor

Furnish and install a belt conveyor 18 inches $\times 25$ feet 1 ong, with capacity of 50 tons per hour, horizontal and inclined slope, complete with head shaft, motor, reducer, drive chain integrated assembly, belts, idlers, loading skirts and discharge hopper, frame and supports.

6) Under-Silo Conveyor

Same as item 5 above except 24 inches wide $\times 45$ feet 1 ong.

\section{7) Elevator}

Furnish and install a continuous discharge type bucket elevator $14^{\prime \prime} \times 8^{\prime \prime} \times 11-5 / 8^{\prime \prime}$ on $85^{\prime} 0^{\prime \prime}$ centers.

Capacity shall be 50 tons of coal per hour of 6" maximum lump size, when traveling at a maximum chain speed of $50 \mathrm{fpm}$.

Casing shall be formed plate, built of $1 / 4$ " plate with flanged angle, dusttight connections. Unit shall be complete with head section, boot section intake and discharge chutes and clean out doors. Unit shall be driven by an 1800 RPM, 460 volt, 60 Hertz, 3 phase TEFC motor, direct connected to a reducer through a flexible coupling. The reducer drives through a roller chain and sprocket set to the elevator head shaft, all mounted on a suitable structural frame. 
8) Over-Bunker Tripper Conveyor

Furnish and install a belt conveyor as specified above for item 5, except 18 inch $\times 40$ foot centers, with stationary trippers at the discharge to each silo.

9) Over-Silo Conveyor

Furnish and install a bunker belt conveyor as specified for item 5, except 18 inches $\times 120$ feet, complete with traveling belt tripper and tracks. Tripper shall be electric motor propelled, automatic type, with frame built of rugged steel construction and equipped with rail clamps, adjustable belt wiper, motor driving mechanism, operator's platform, crossover platform, track limit switches, reversing mechanism and one three-pulley troughing idler.

10) Under-Bunker Conveyor

Furnish and install one under-bunker conveyor $12^{\prime \prime} \times 1-1 / 2^{\prime \prime} \times 20^{\prime}$ centers, $40 \mathrm{fpm}$, capacity of 25 tons per hour, flight conveyor, complete with chain and flights, trough, and frame of steel with dust tight construction, leveling devices, 12 single bunker outlet gates and 2 triple bunker gates. Drive will be complete with 25. HP motor, 900/1800 RPM, 460 volt, 3 phase, 60 Hertz direct connected through flexible coupling to a speed reducer, which in turn will be connected to the conveyor head shaft by means of a roller chain and sprocket set. Provide a recycle chute to allow carryover to return to elevator boot sections or be diverted to discharge out of building.

11) Coal Scales

Furnish and install two special length automatic coal scales, totally enclosed, \#200 dump with a capacity of 15 tons per hour. Scale shall be complete with motor, recorder and 7 imit switches so that when the coal is available in the surge hopper, the conveyor will start and run until the full limit switch in the top of the hopper stops the conveyor.

Flexible inlet and discharge hopper will be provided with each scale, built of $1 / 4 "$ stainless steel plate. Scales will be dust tight and provided with inspection doors.

12) Chutes

Conical distributor chutes shall deliver the coal from the scale discharge openings to the stoker hoppers. The distributor chutes shall be designed to prevent segregation of coal to the stoker hopper and will be complete with emergency firing doors, flexible connections, and no-flow switches.

13) Control Panel

Furnish and install one control panel including all switches, relays and start-stop pushbuttons required to control all feeders, conveyors, elevator and coal crusher, integrating all units into one automatic operation. 
k) Ash Hiandling System

Furnish and install ash handling equipment including bottom ash intake connections, sifting hopper intake connections, boiler hopper dust intake valves, dust collector intake valves, ash piping, primary receiver, secondary dust separator, exhauster, air washer filter vent, dustless unloader and control panel.

System shall be capable of removing an ultimate total of 10 tons of ash and fly ash per hour, initially 5 tons per hour.

Each boiler shall be equipped with four (4.) vertical lifting doors 22". × 26" cast iron machined for air tight seal, refractory lined. The feeding hoppers shall be equipped with a combination ash crusher and feeder, rotary, driven by a common gearhead motor and line shaft for all four gates.

Sifting hoppers, boiler dust hoppers and dust collector outlets, approximately 8 per boiler, shall be equipped with air-operated discharge valves arranged for automatic sequence operation. The ash piping and fittings shall be a hard alloy, abrasion resisting metal "Nuvaloy" or equal, suitable for the temperature encountered -- 8" and 6" sizes.

All bends and elbows shall be Durite sectional semi-sweep type, with removable wearing sections. Each conveyor branch shall be complete with an air inductor fitting and automatic operating check valve. Provide vacuum breaker in ash transport line at the vertical riser to the primary receiver.

Primary receiver shall be a cylindrical tank with conical bottom suitable for this service and constructed of sectional hard metal cast plates.

The secondary external dust collector shall be mounted on the swing gate housing with the primary receiver. The secondary collector shall be not less than $16^{\prime \prime}$ in diameter.

The receiver and dust collector shall each have a discharge gate housed within a common housing set on the ash storage bin roof slab, for discharge to the silo.

A steam jet exhauster shall be used to provide motive force to transport the ash. The unit may be a single or multiple jet unit.

Provide an air washer of the double-stage cyclone type to thoroughly extract the dust from the steam and transport air. The air washer shall be constructed of at least 3/4" thick hard cast iron wear plates at the entrance and upper portion of the washer. The balance of the washer may be constructed of $1 / 4^{\prime \prime}$ "steel plate. Provide necessary water and waste connections.

Provide a 3-bag, self-cleaning filter vent for installation on the storage bin roof, arranged for automatic pulse cleaning.

Provide a rotary dustless ash conditioner, drum-type, having a capacity of 30 tons of ash per hour. 
The ash conditioner mixes thoroughly the ash with water to provide a dustless mixture to be discharged to a truck for hauling to landfill.

Unit shall be complete with receiving hopper and slide gate and rotary vane feeder at the inlet of the conditioner, powered by a 1 HP motor.

The ash conditioner drive shall have a $5 \mathrm{HP}$ offset gear head motor. Provide a discharge chute for discharge to the receiving trucks.

Provide necessary water supply and drain to the unit.

Furnish and install a prepiped and prewired control panel with manual-automatic selector switch, indexing controls, indicating lights and all operating relays, vacuum switches and sensors.

Provide all interconnecting tubing and prefabricated electrical cable and terminals. 
4.b.4 PRELIMINARY DESIGN: ELECTRTCAL \& INSTRUMENTATIION SYSTEMS

4.b.4.1 Electrical

Preliminary design drawings are included in this Section.

4.b.4.2 Instrumentation

Preliminary design drawings of the instrumentation systems are included with the material in part 4.b.3.2 of Section 4.b.3. Identified there also are components and systems needed solely for evaluation of ICES performance. 


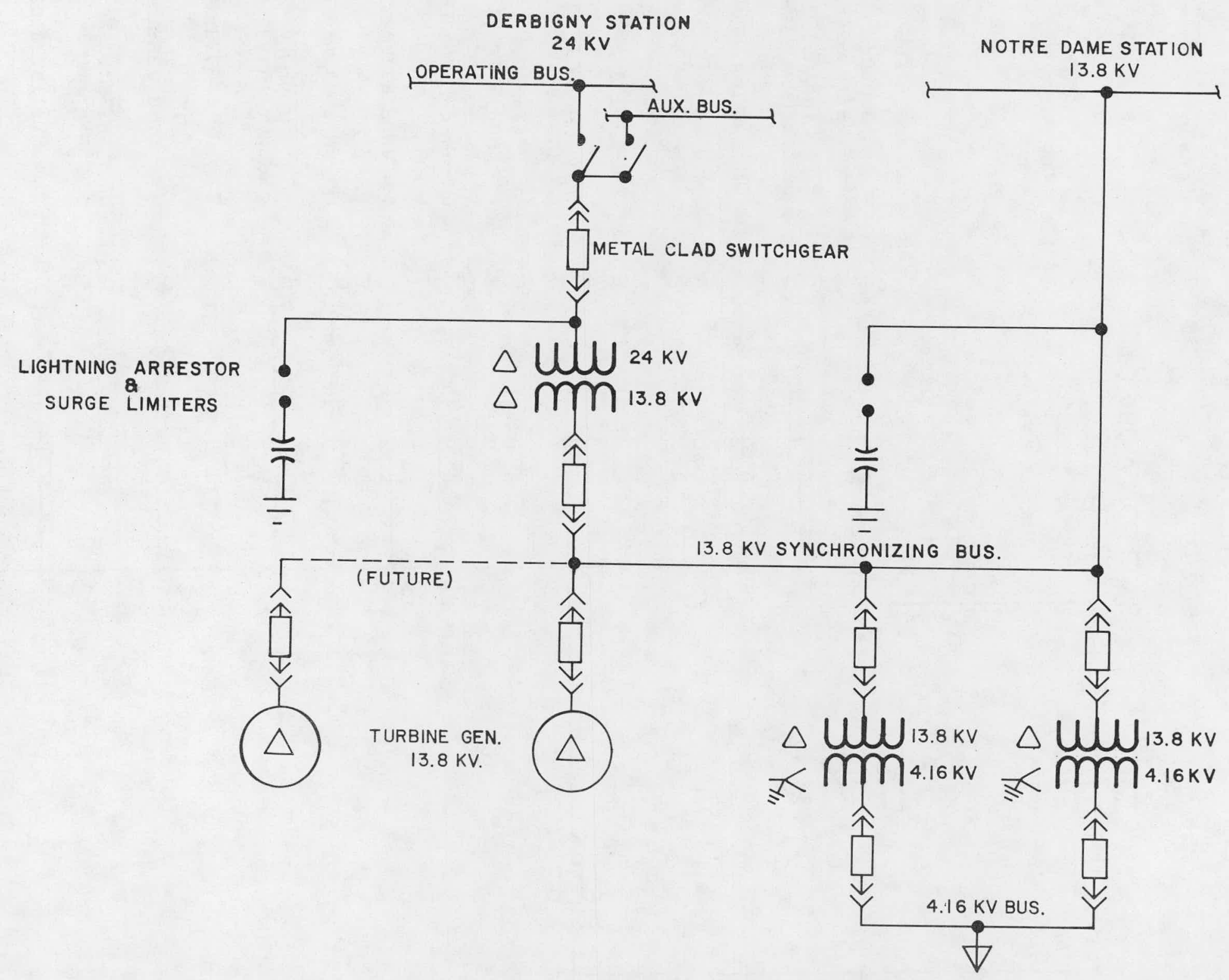

㐫 


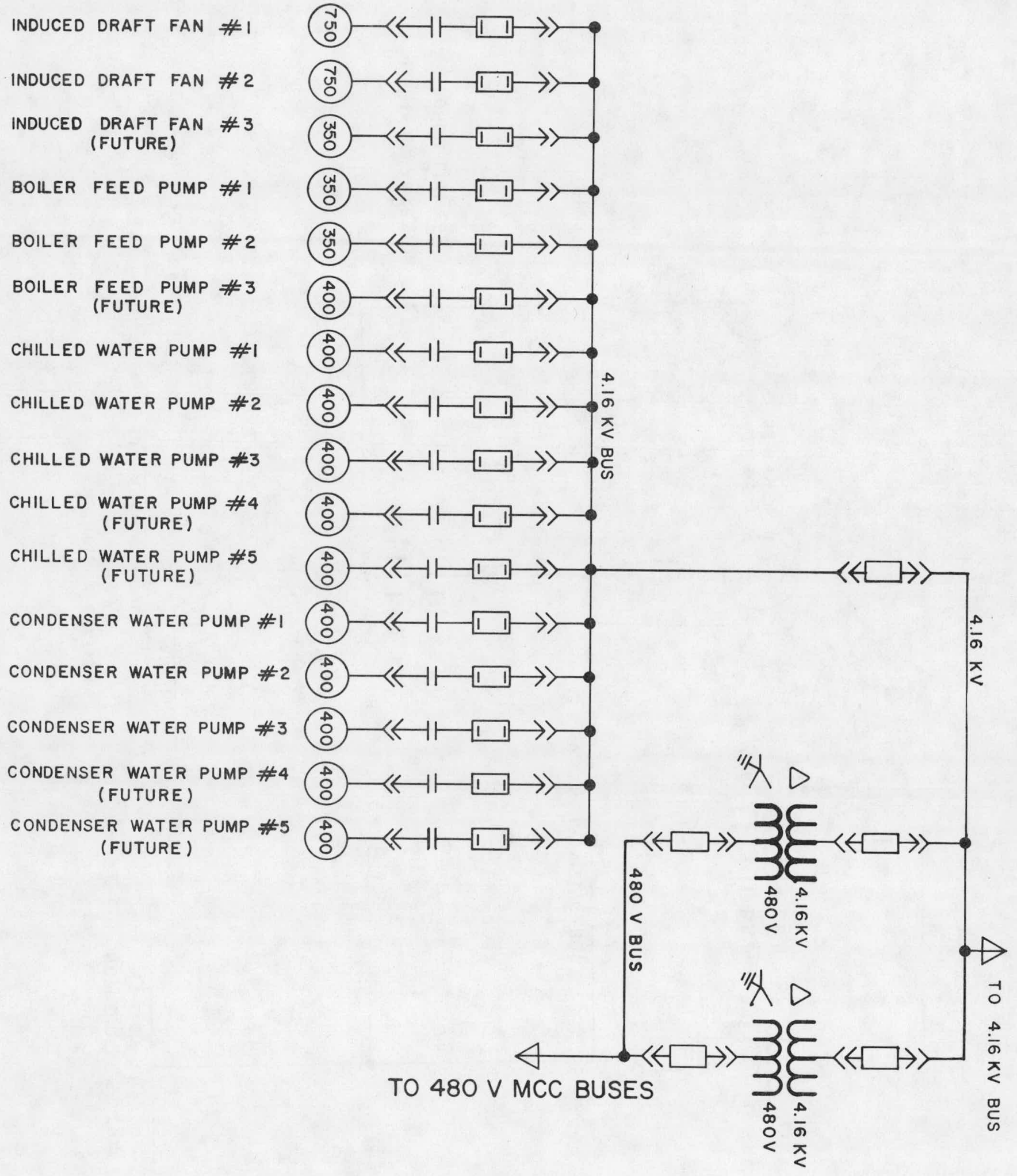

ONE LINE SCHEMATIC-ELECTRICAL

(4.16 KV SYSTEM) 


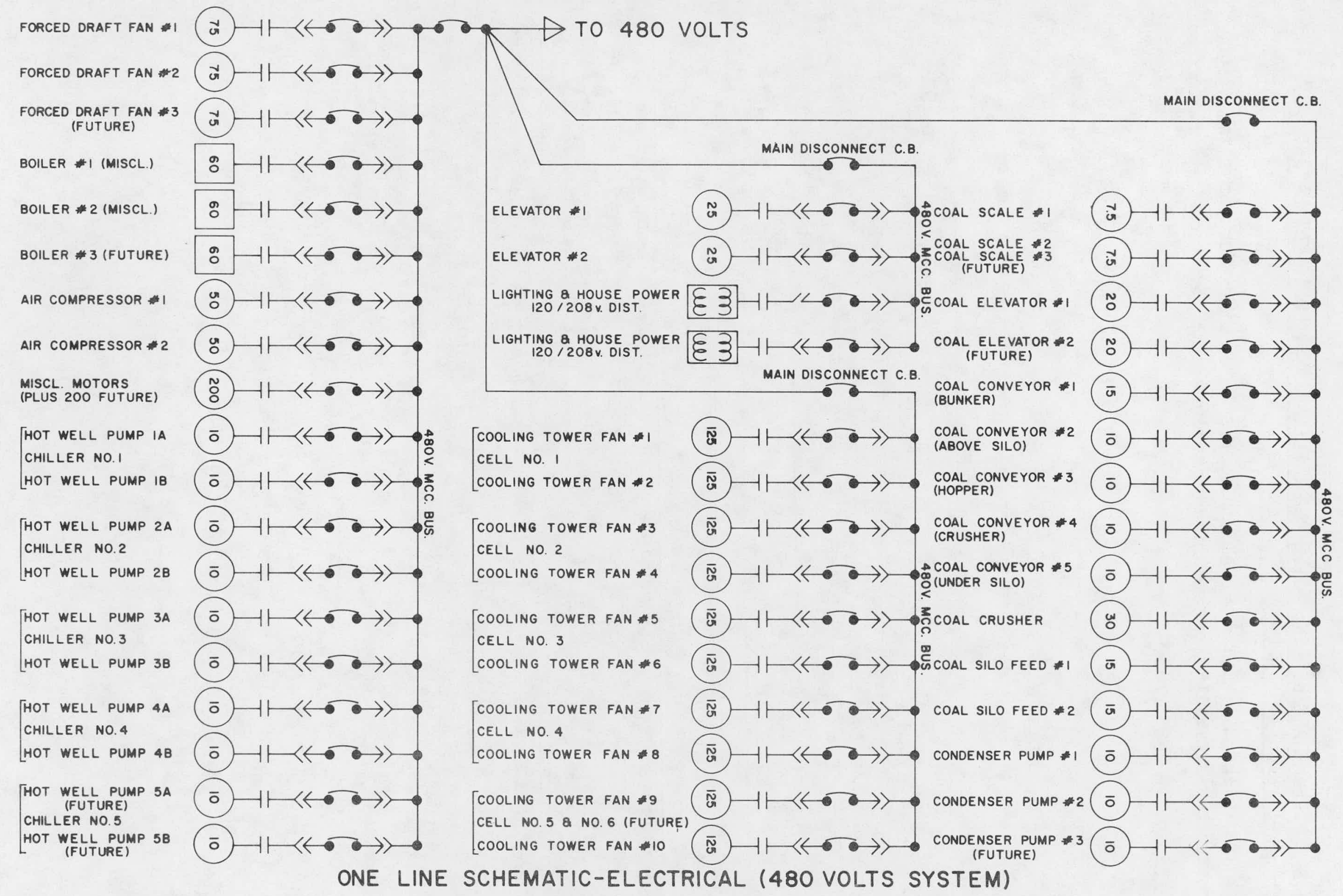


4.b.5 PRELIMINARY DESIGN: SITE PLAN, ELEVATIONS, EQUIPMENT LAYOUT, DISTRIBUTION SYSTEMS

Included in this Section are preliminary design drawings for the site, plant structure, plant systems and distribution systems. 

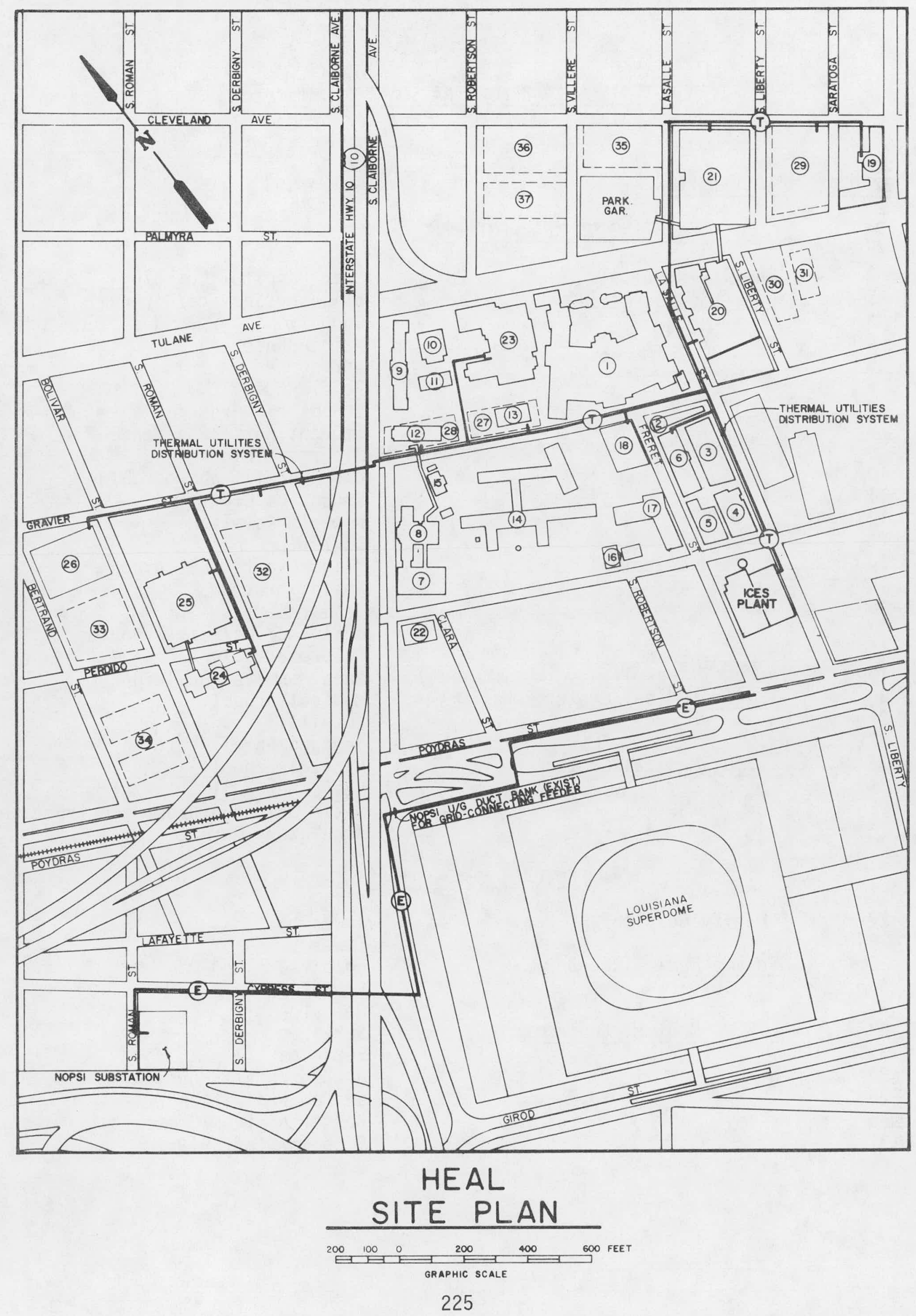
$\underline{\text { NUMBER }}$ INSTITUTION

\section{EXISTING OR NEAR FUTURE}

Charity Hospital

V. A. Hospital

E.E.N.T. Hospital

Tulane Medical Center

L.S.U. Medical Center

\section{BUILDINGS}

FUTURE, BEYOND 1982

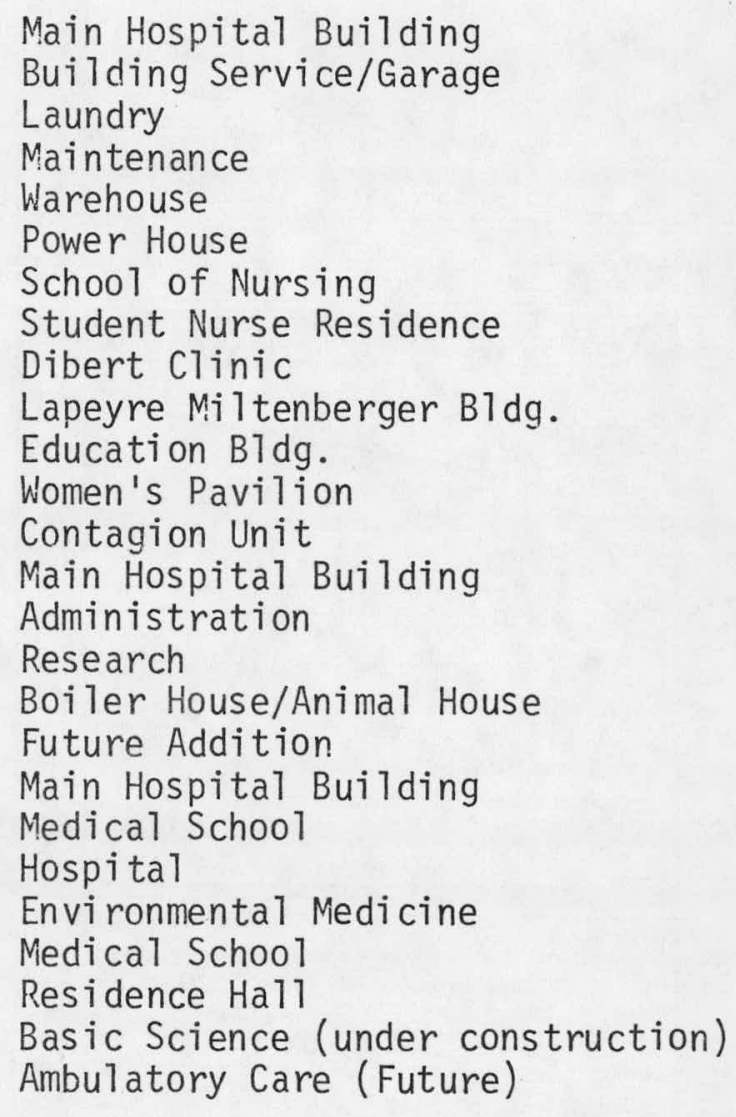

Tower

Tower

Hospital

Education

Research

Services

Services

Student/Staff Housing

Shared Facilities

Doctor Offices/Commerical

Student/Staff Housing 


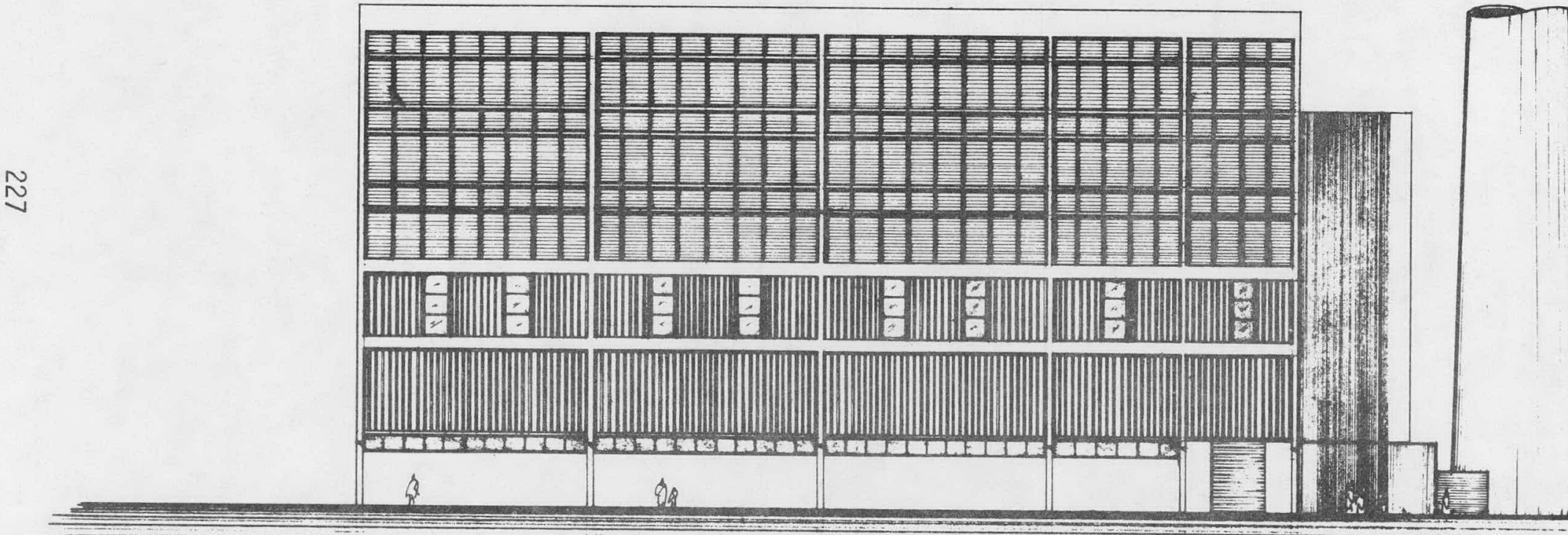

STACK

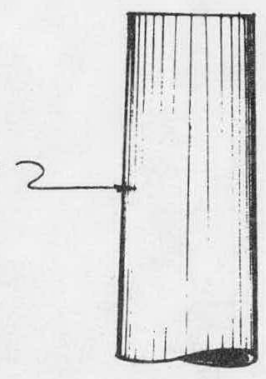

ELEVATION

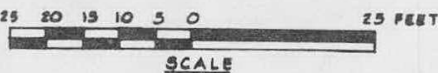




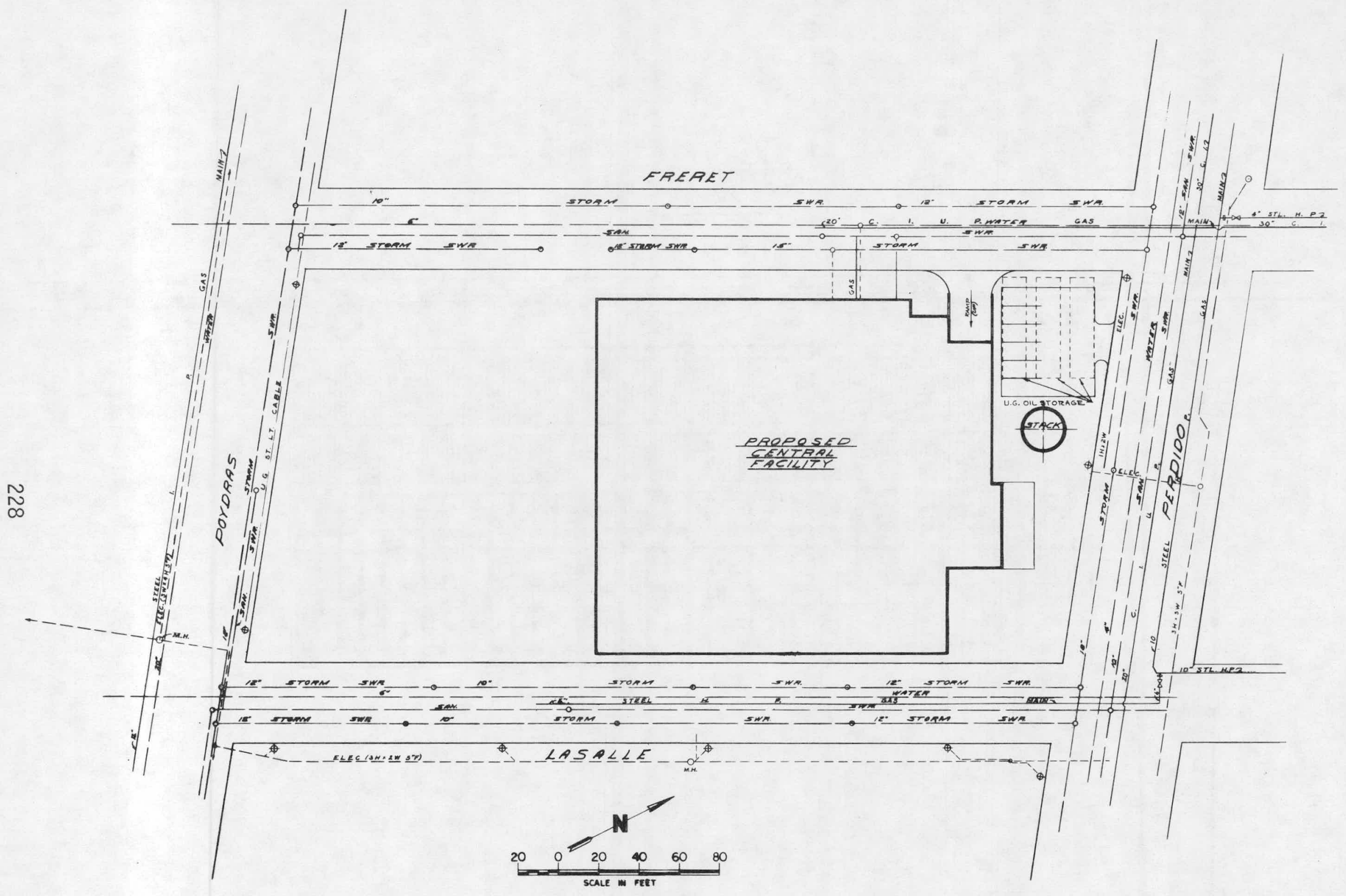




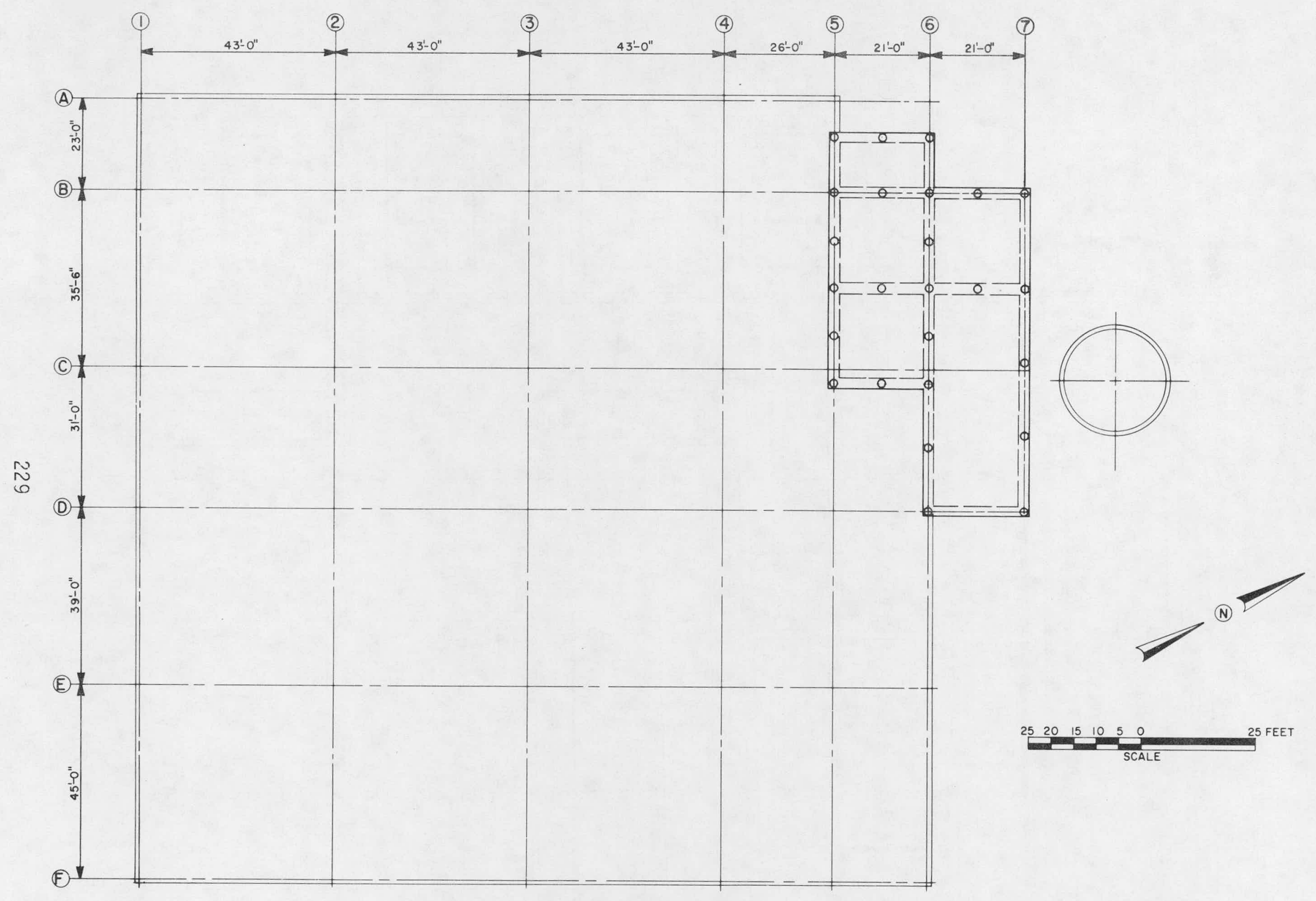

COAL CRUSHER LEVEL EL. 73 


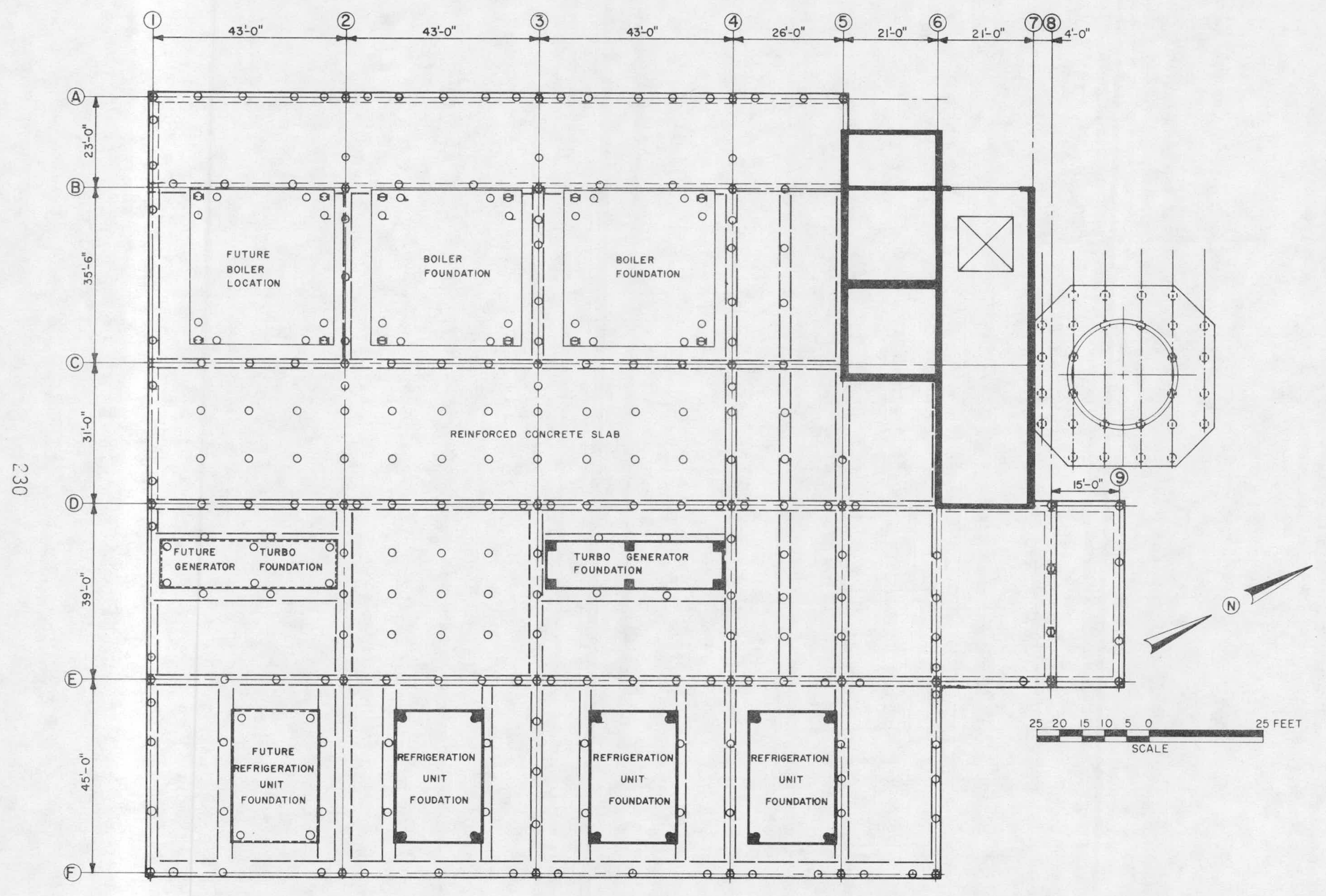




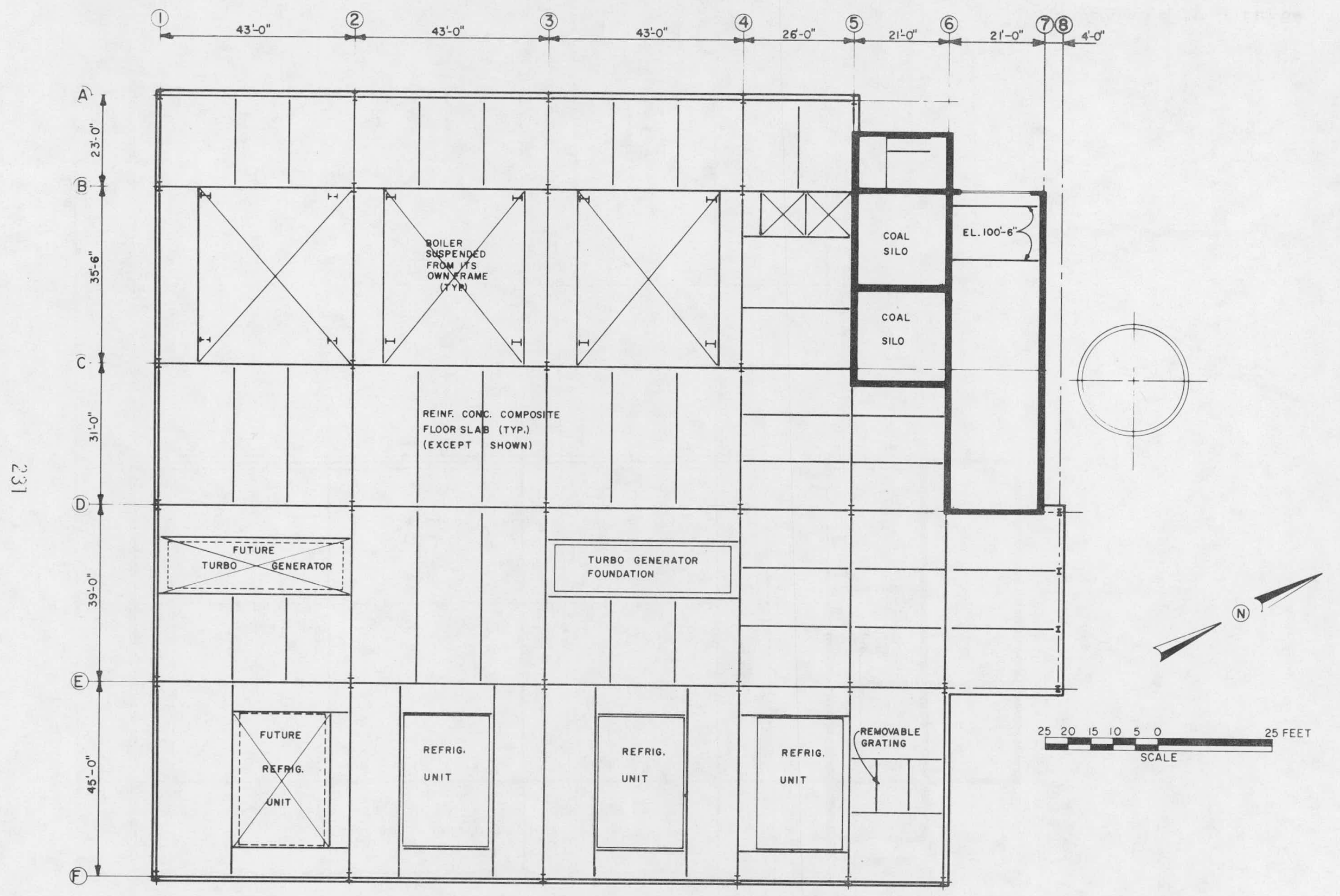




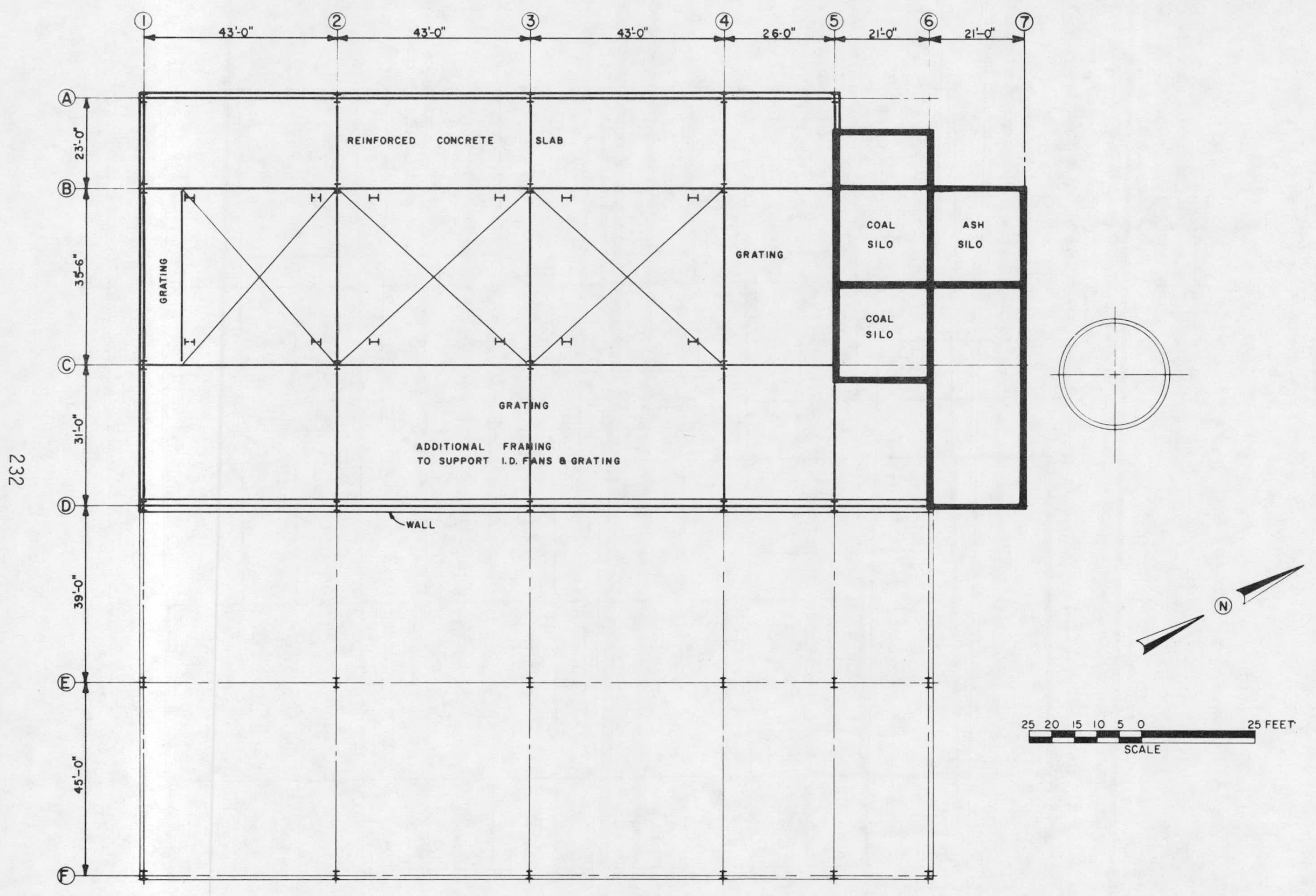

COAL BUNKER FLOOR EL. 117 


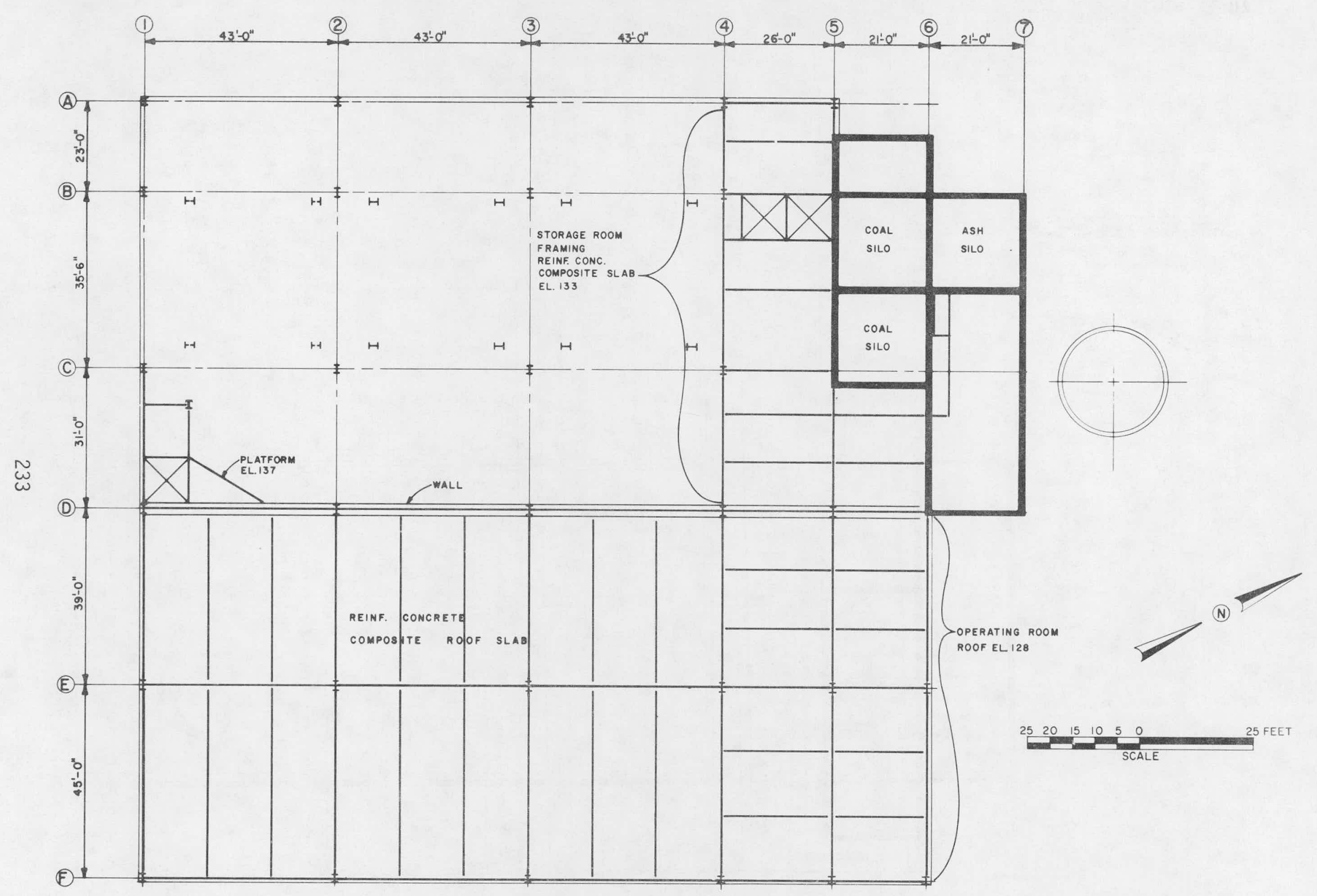




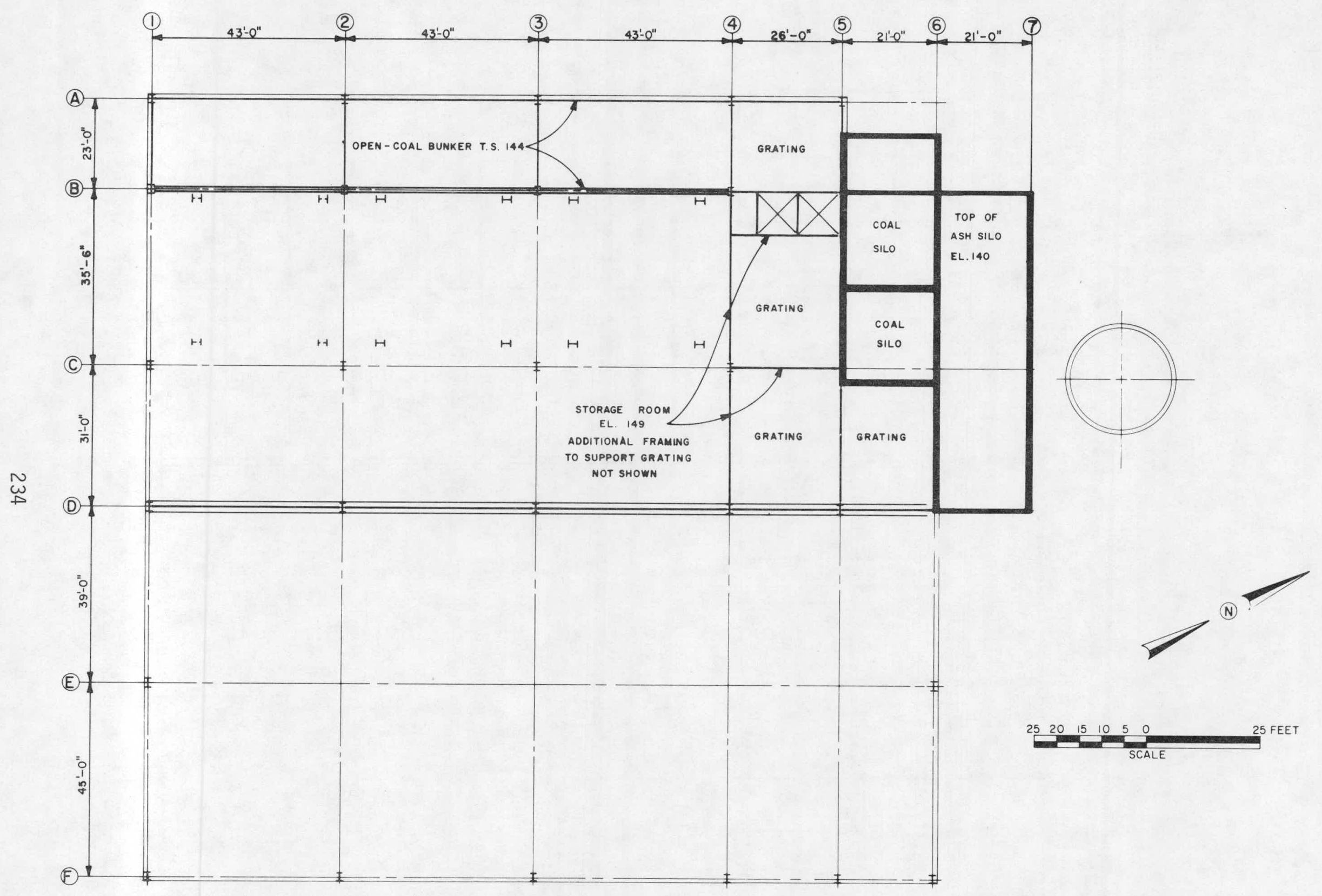




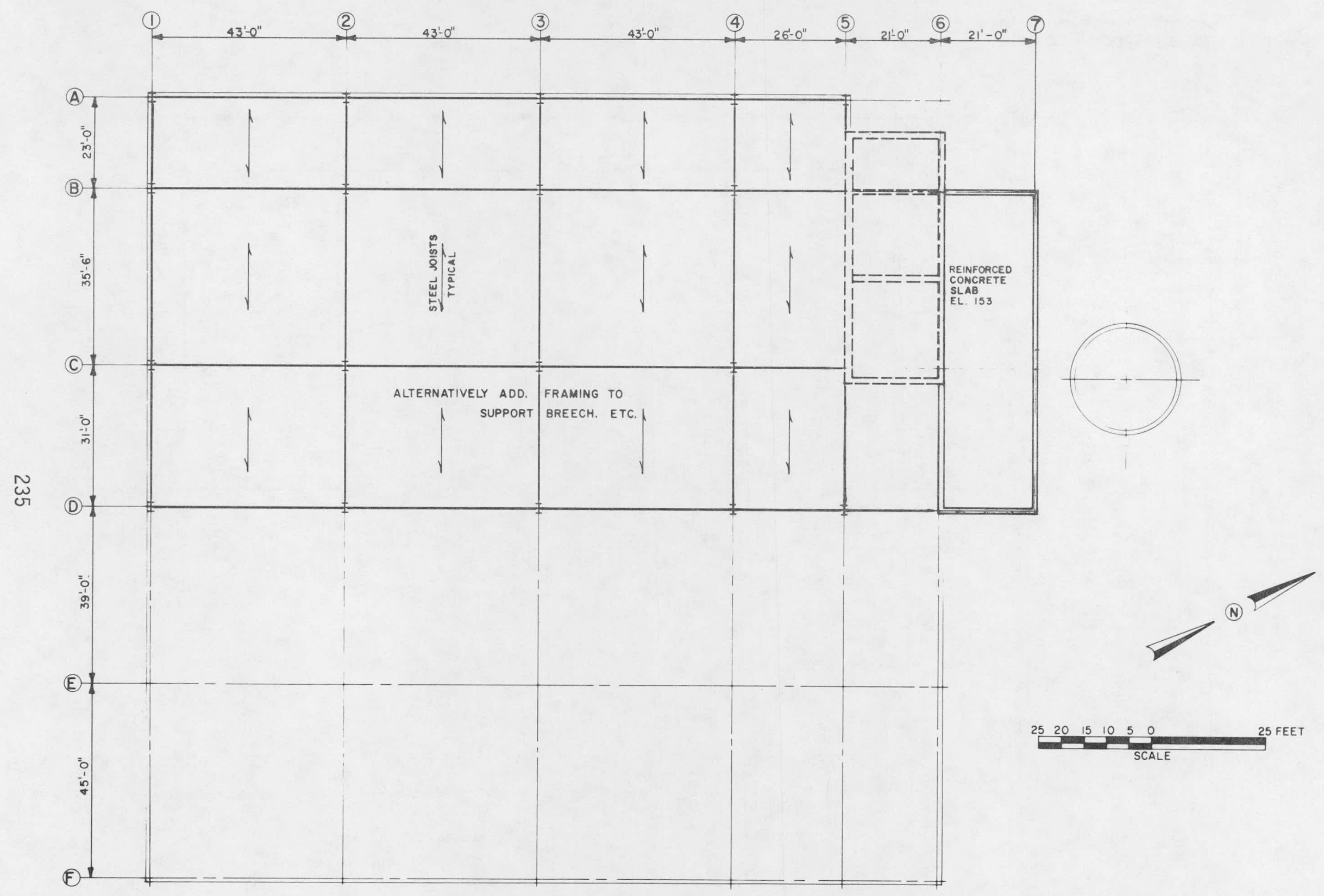

ROOF BOILER HOUSE EL. $162( \pm)$ 


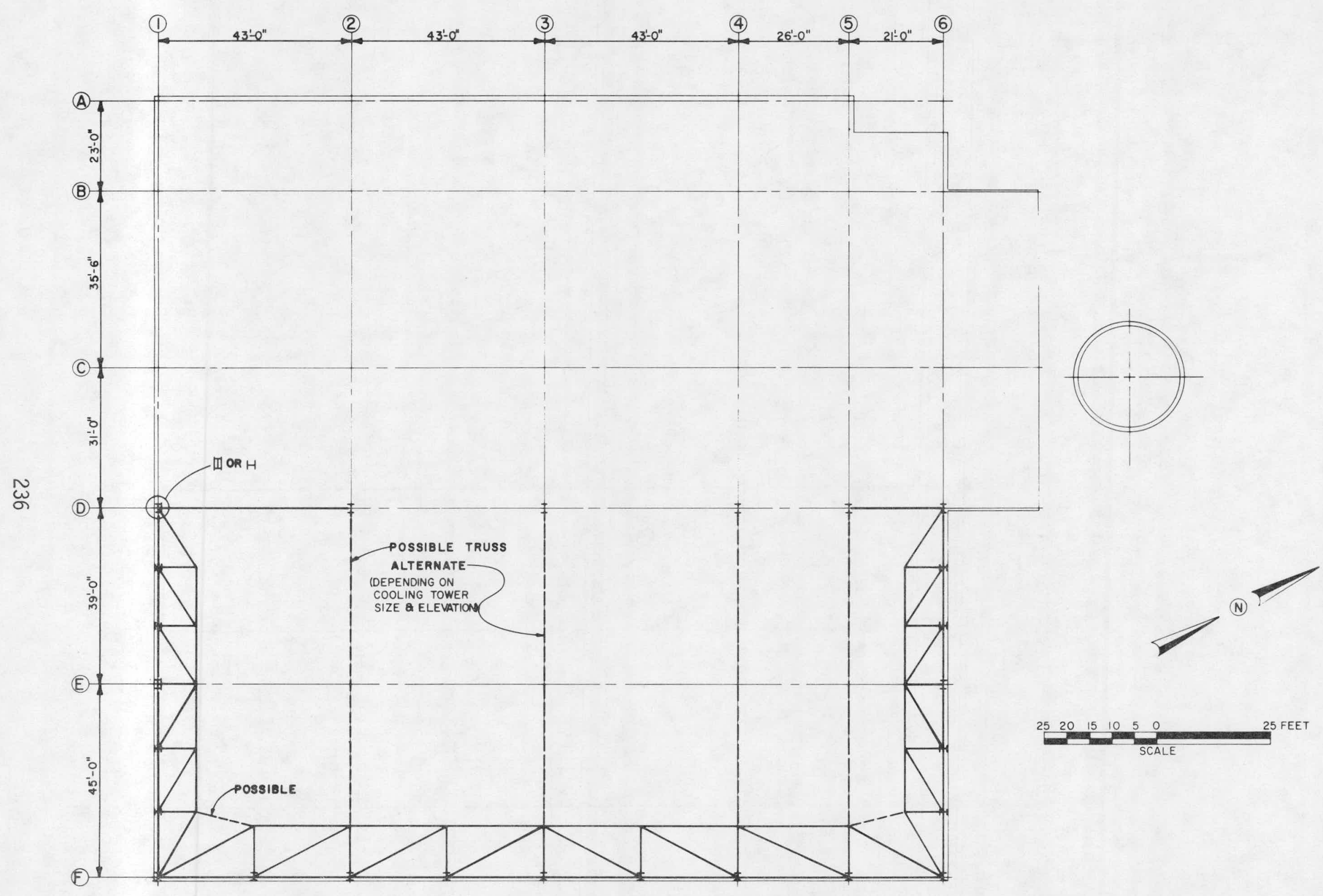

TOP COOLING TOWER EL. 184 


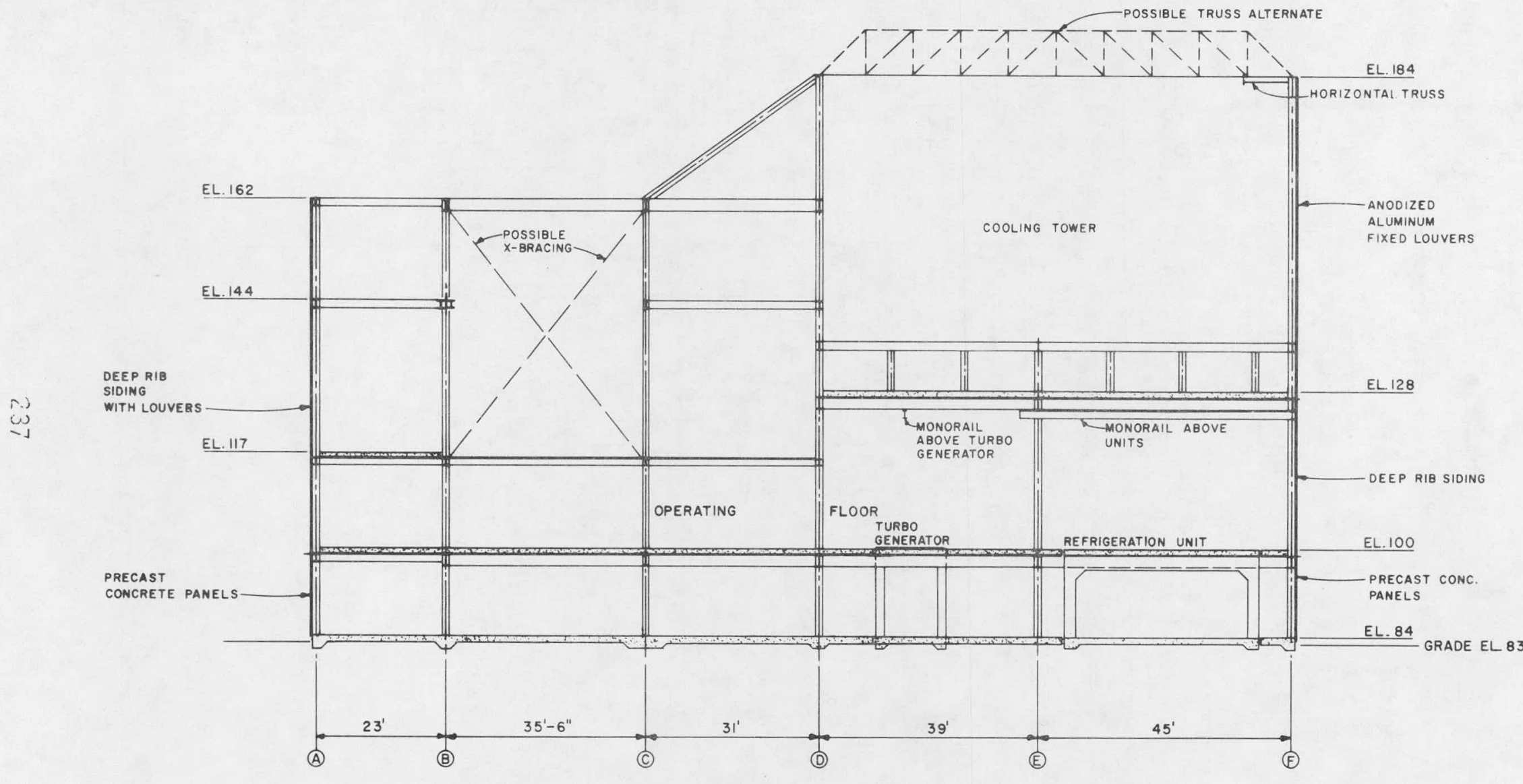




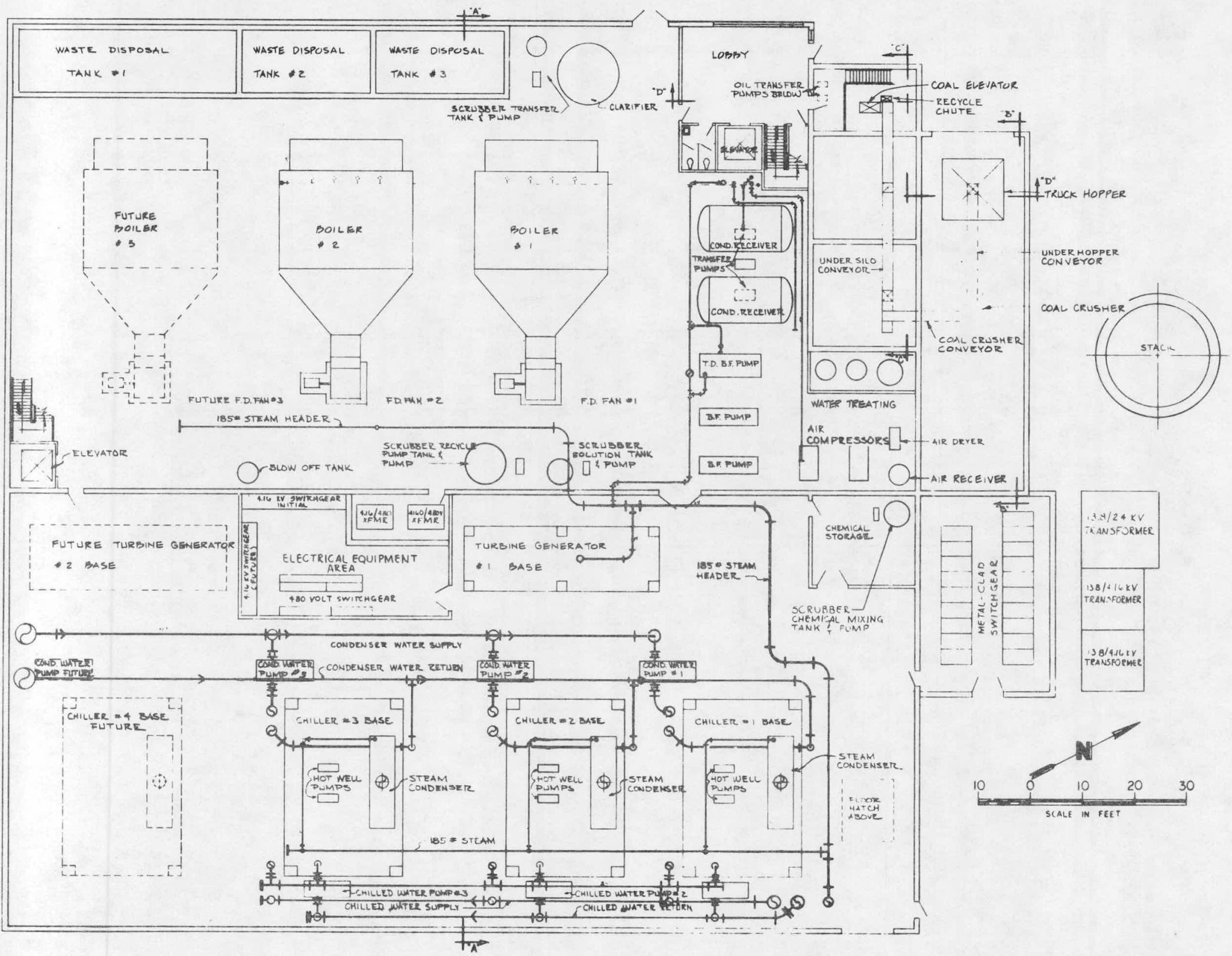

GROUND FLOOR EL. 84' 


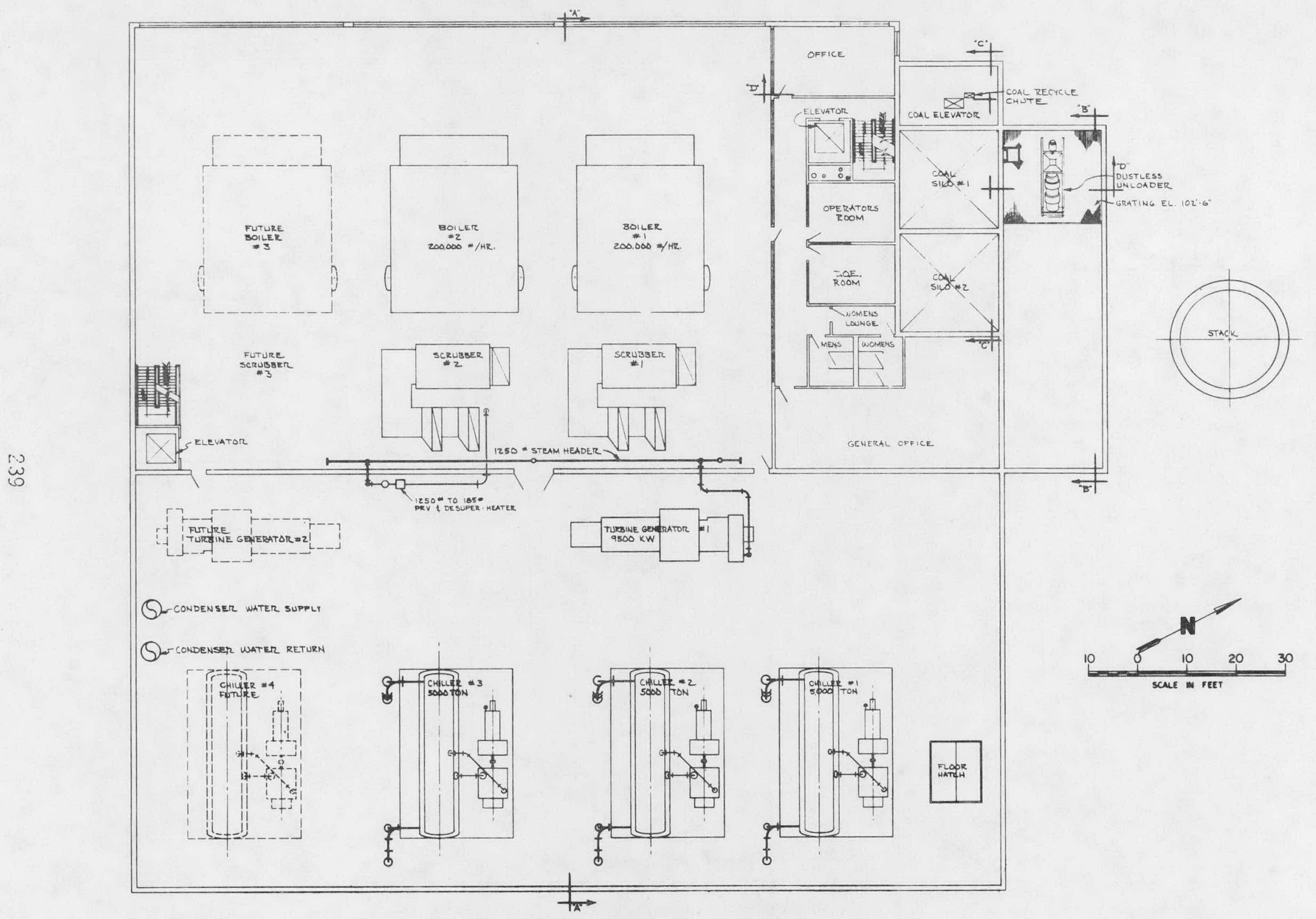

OPERATION FLOOR EL. 100' 


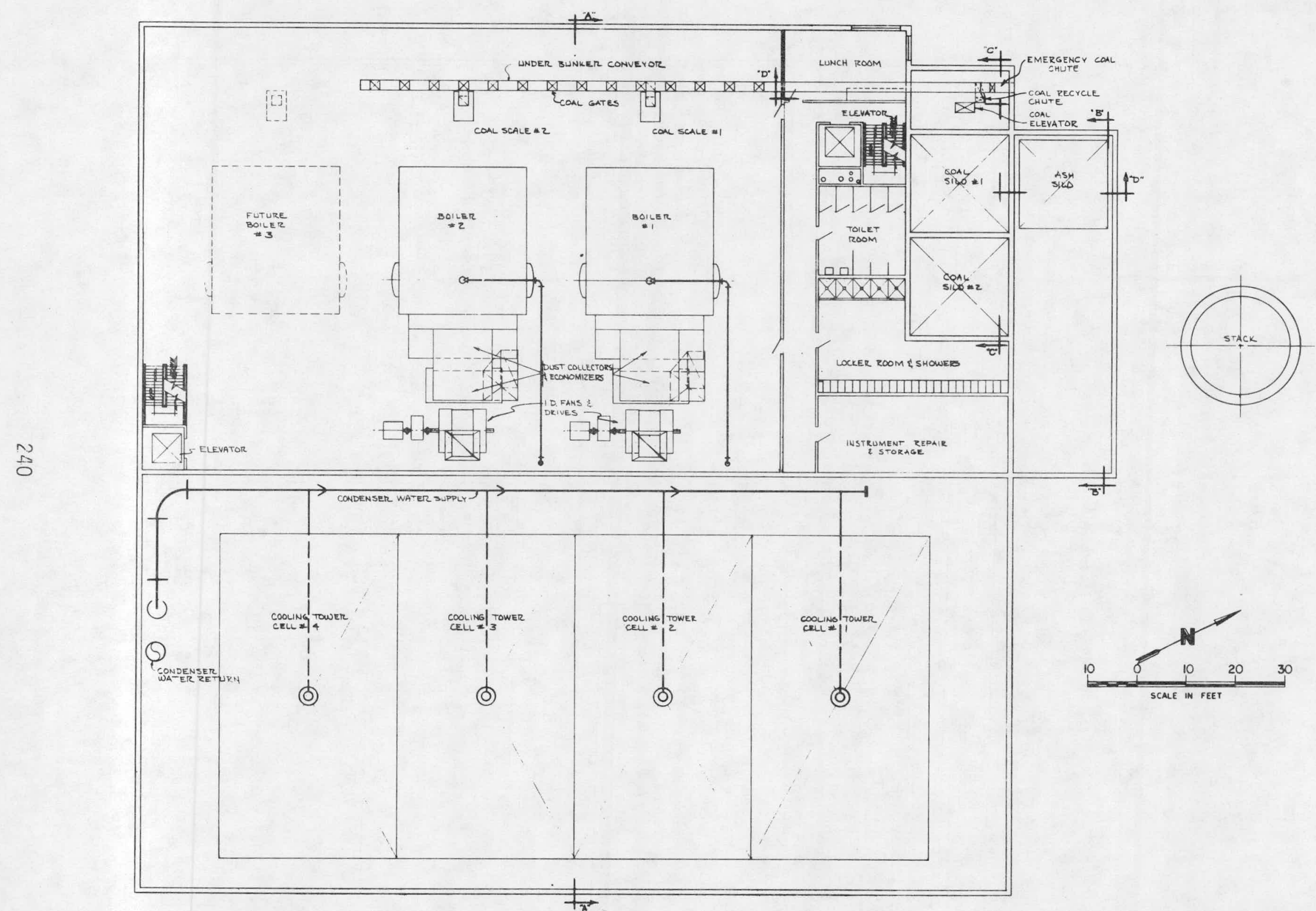




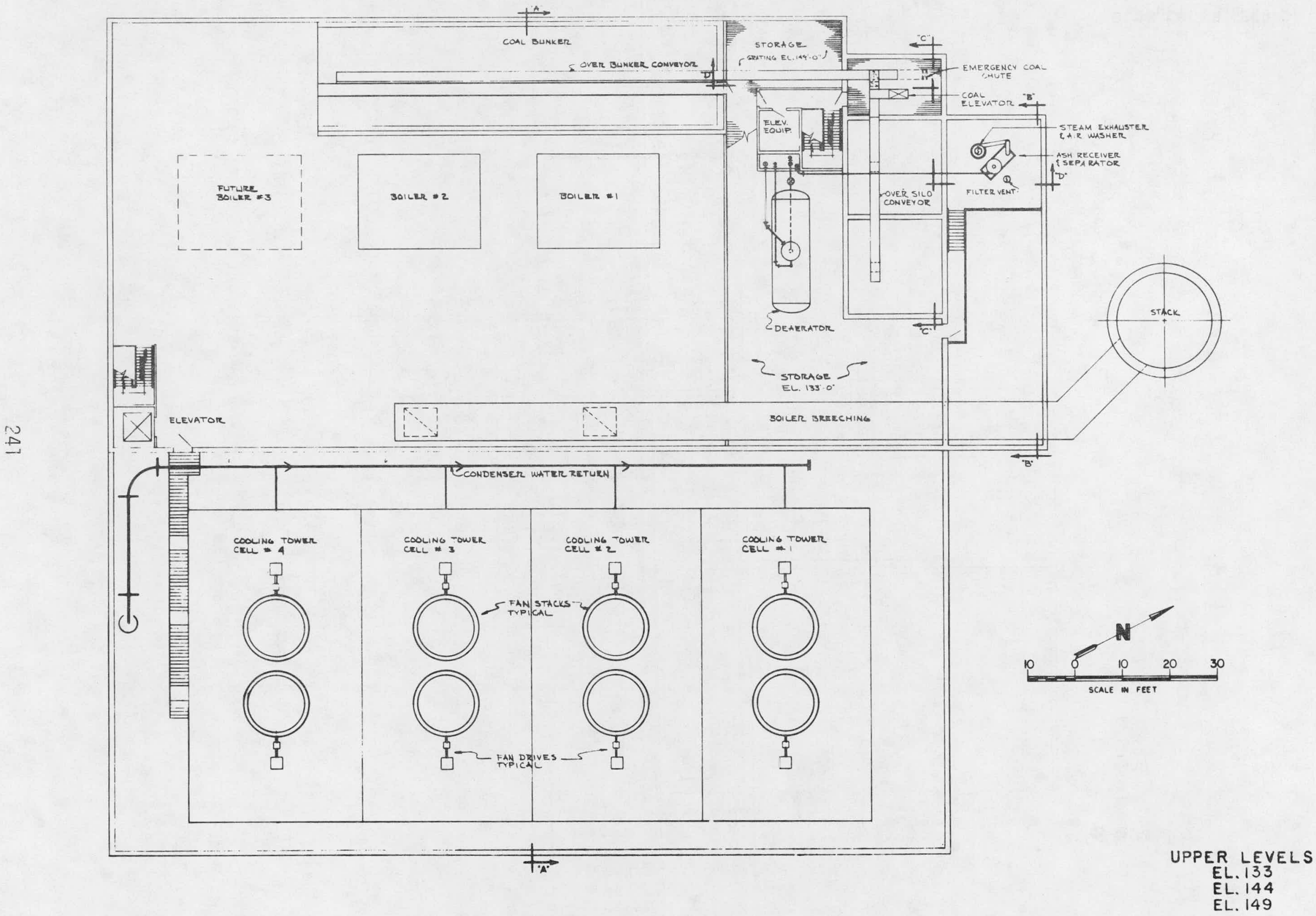




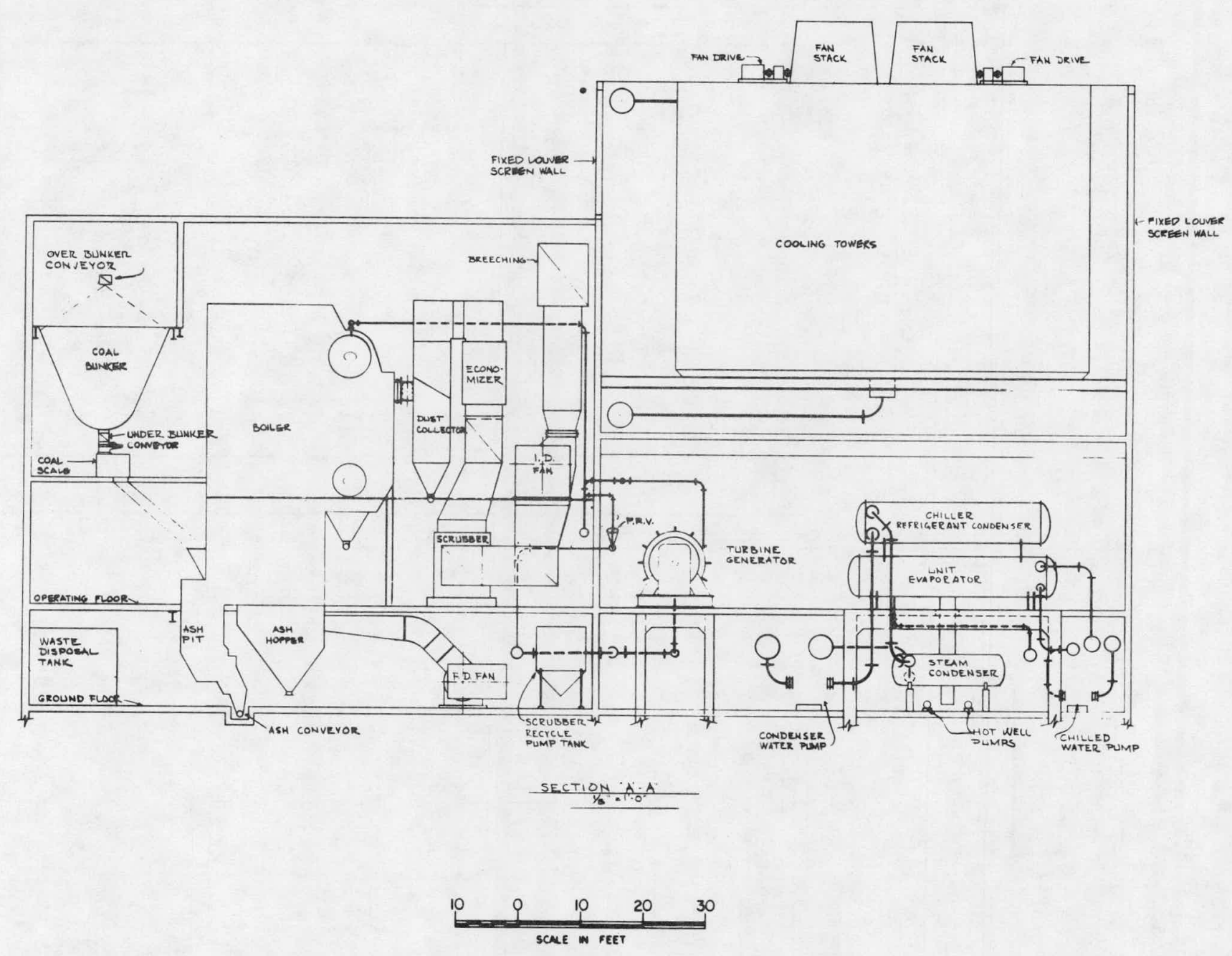

BLDG. CROSS SECTION 

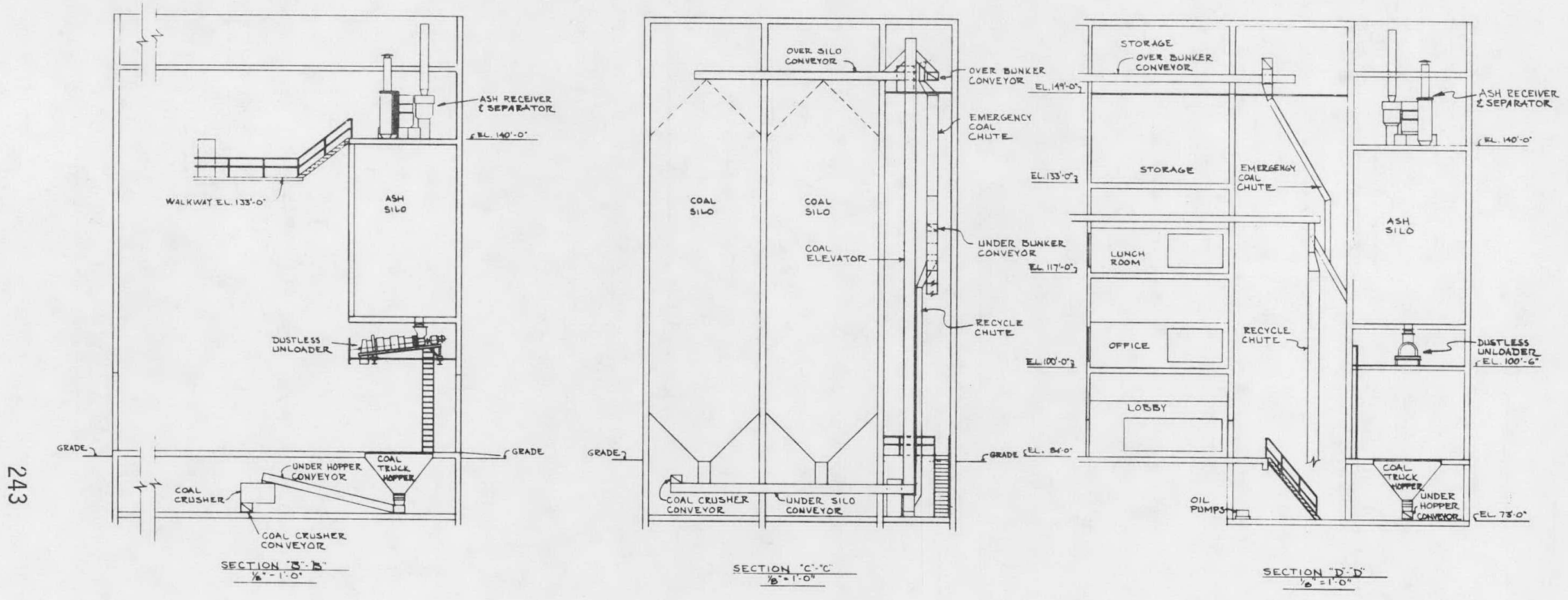


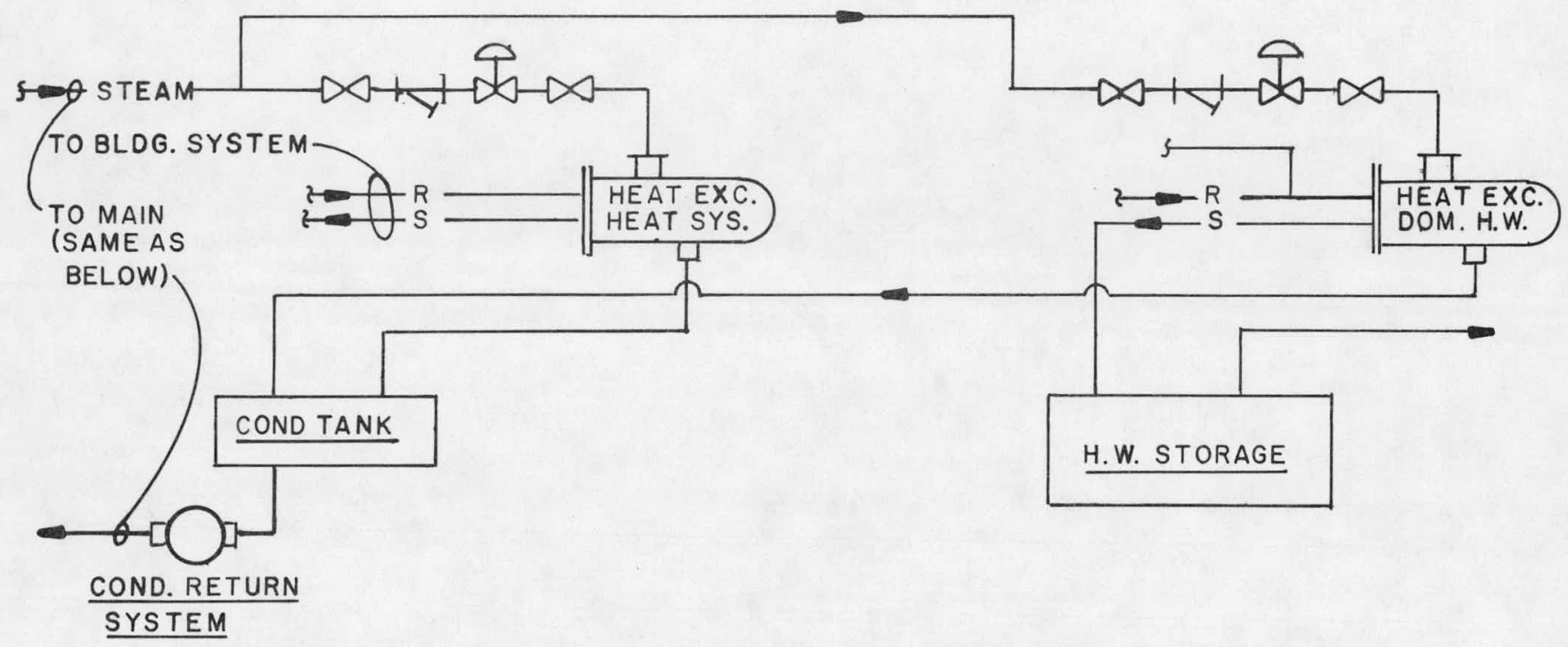

INTERNAL STEAM \& HOT WATER SYSTEMS

L.S.U. RESIDENCE HALL ONLY

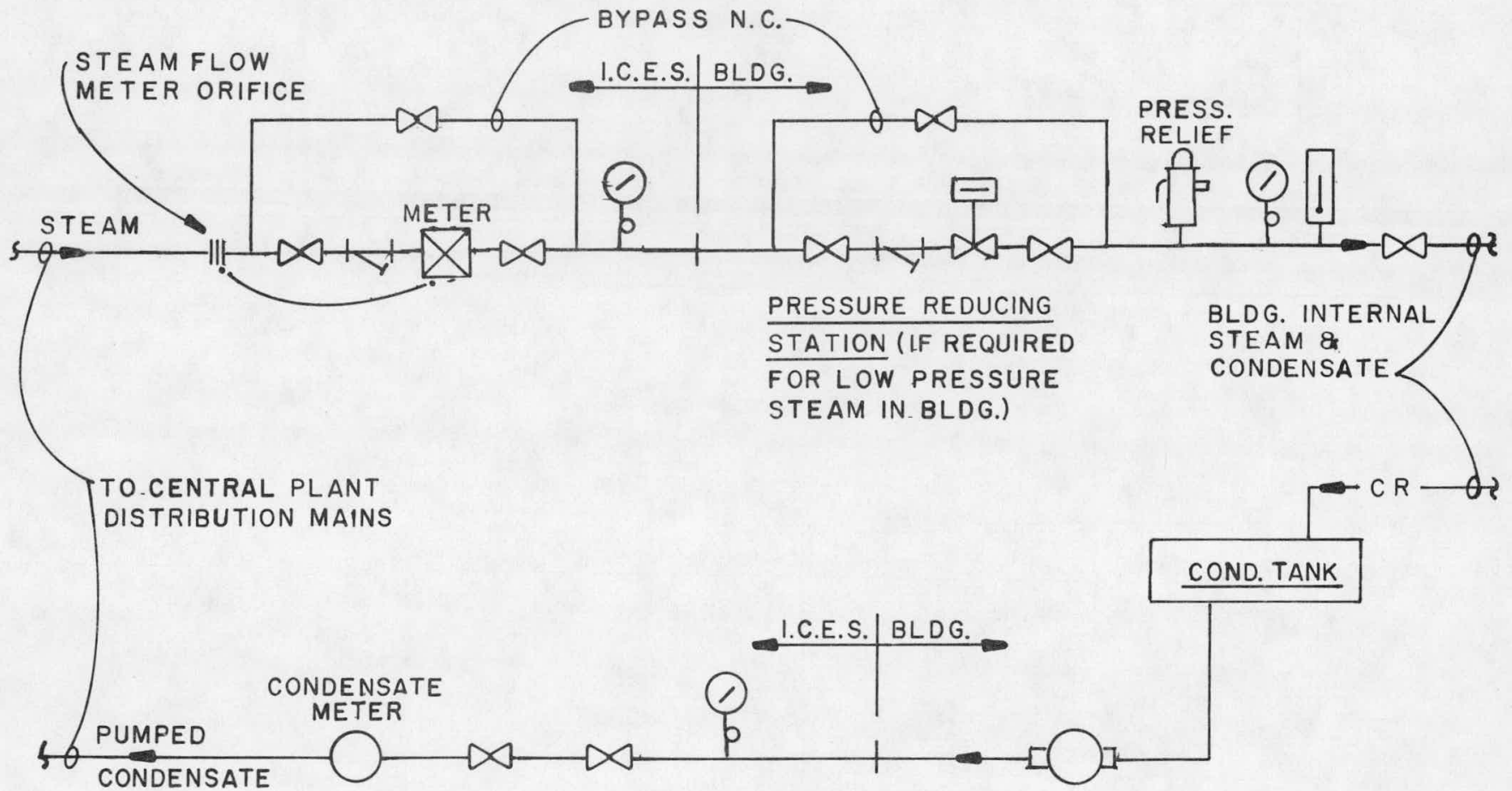

BLDG. DUPLEX COND. RETURN UNIT PSI DISHARGE PRESSURE

TYPICAL STEAM \& CONDENSATE AT H.E.A.L. BUILDINGS 


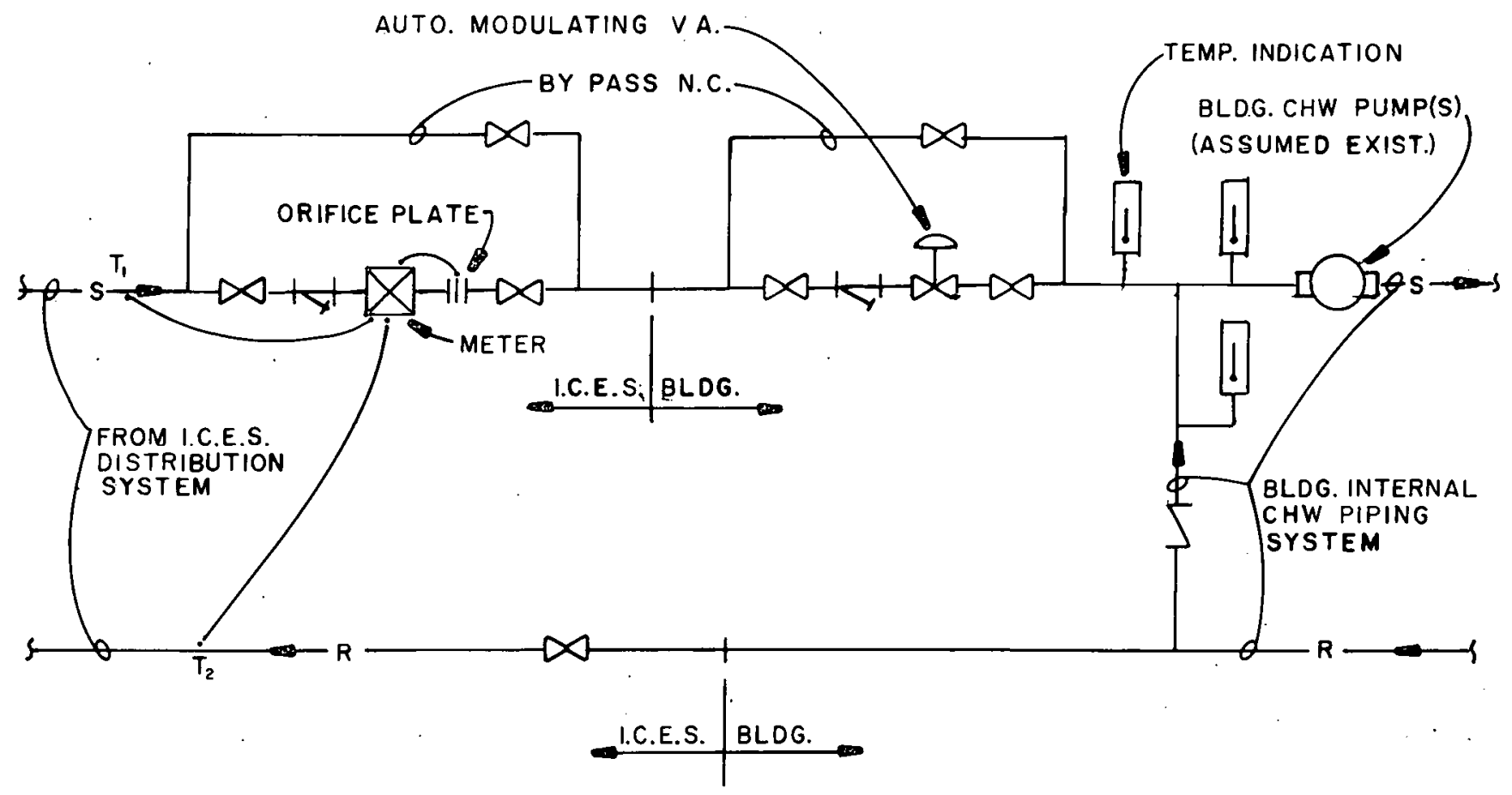

TYPICAL CHILLED WATER AT H.E.A.L. BUILDINGS 


\section{4.b.6 ENGINEERING ANALYSES}

\section{4.b.6.1 General}

Engineering analyses and load projections, based on a coal-fuel plant, to the year 2000 are presented herein in Tables XII and XIV and, serve as the basis for the Projected Plant Cash Flow, Table XXIII, and for Projected Plant Reserve Fund, Table XXIV, in Section 5.b.3. Comparable values are presented for a gas-fuel plant in Tables XIII and XV. In Table XVI estimated credits for sales of excess power to the utility company's electric grid are given for coal-fuel and gas-fuel plants. Table XVII presents estimated energy and cost projection data for the total of existing individual plant systems, gas fired, without ICES. Energy input comparison for the ICES plant between gas fuel and coal fuel appears in Table XVIII.

\section{4.b.6.2 Methodology}

The data presented in 3a.2.4, "Operational Parameters and Annual Operating Cost", forecast the estinated fuel consumption, total steam generated, as well as the total electrical energy generated, for the first operating year assumed to be year 1982, as summarized in Table XI, Steam and Electrical Generation, and Fuel Consumption. Data in Table XI were based on demand and consumption levels developed for the year 1982 as presented in Table $X$.

The load projections are assumed to follow the space growth projection and have been tabulated in Table XII. The space growth rate is approximately $5.2 \%$ per year, steam heating demand at $4.5 \%$, and refrigeration demand at $5.86 \%$ per year. (See Charts I, II and III in Stage I Report). Steam consumption increases at the rate of $3.9 \%$ per year and cooling requirements increase at the rate of $4.2 \%$. The building space for HEAL institution expansion and consequent load increases will, of course, not occur as a smooth gradual growth but will occur in rather sizeable increases every few years to attain the projected space and load requirements by the year 2000. Table XII has been noted as to the derivation of the values in each column for each year and summarizes in total steam generated, column 8, which then is converted to tons of coal, column 9. Column 10 is the cost per ton of coal delivered to the plant escalated at $5 \%$ per year and these, multiplied by column 9 values, produce column 11, cost of coal per year, summarized at $\$ 129,384,200$.

Electrical production and use are tabulated in Table XIV. The electrical power required to produce 1000 pounds of steam is estimated at $3.5 \mathrm{KW}$ and the electrical power required to produce 1000 tons of refrigeration is estimated at $225 \mathrm{KW}$, which make up columns 1 and 2 and are summarized in column 3, Total Plant Use. Column 4 is the total electrical energy generated as the by-product of the steam and refrigeration production.

The total plant electrical requirements are to be served by utilizing $75 \%$ from the plant generating capacity and 25\% purchased from NOPSI through the auxiliary standby connection, thereby utilizing the standby charges for this service. The cost of purchased power has been escalated at $8 \%$ per year and is reflected in column 8 , Cost, Purchased Power. 
The amount of electrical energy available to the grid, and to be sold, is indicated in column 9 . The sales price will be dictated by the prevailing cost to iNOPSI for purchase from the network.

Fuel and energy price projections were derived from Ilaval Facilities Engineering Command "Energy Escalation for Short Term Costing and Life Cycle Costing", using long-term (20 to 25 years) figures; from Federal Energy Administration figures published in the June 1977 Federal. Register -- "Energy Audit Procedures, Table 6, Energy Prices in 1977 Dollars per Fuel Unit" for FEA Region VI, Southwest (with prices assumed constant from 1991); and from various utilities and other nigh-level energy consumers. 
TABLE NO. $X$

UT ILITY SERVICE

\begin{tabular}{|c|c|c|c|c|}
\hline \multirow[b]{2}{*}{ Building } & (1) Stean & n System & \multicolumn{2}{|c|}{ Cooling System } \\
\hline & $\begin{array}{l}\text { (2) } \begin{array}{l}\text { Demand } \\
\mathrm{Lbs} / \mathrm{Hr}\end{array} \\
\end{array}$ & $\begin{array}{l}\text { Annua } 7 \\
\text { Lbs } \times 10 \\
\end{array}$ & $\begin{array}{c}\text { Demand } \\
\text { Tons } \\
\end{array}$ & $\begin{array}{l}\text { Annual } \\
\text { Ton Hrs. } \times 10^{3}\end{array}$ \\
\hline $\begin{array}{l}\text { Eye, Ear, Nose, Throat Hosp. } \\
\text { L.S.U. }\end{array}$ & 3,730 & 10,250 & 220 & 739 \\
\hline $\begin{array}{l}\text { Residence Hall } \\
\text { Medical School } \\
\text { Basic Science (under const.) } \\
\text { Amb. Care/Clinic (future) } \\
\text { Sub-Total }\end{array}$ & $\begin{array}{r}3,540 \\
10,000 \\
13,400 \\
6,250 \\
33,190\end{array}$ & $\begin{array}{r}5,010 \\
20,020 \\
26,850 \\
12,500 \\
64,380\end{array}$ & $\begin{array}{r}300 \\
1,000 \\
1,340 \\
\quad 625 \\
3,265\end{array}$ & $\begin{array}{r}937 \\
3,233 \\
4,324 \\
2,022 \\
10,516\end{array}$ \\
\hline Tulane & $\therefore$ & " : & & \\
\hline $\begin{array}{l}\text { Medical School } \\
\text { Hospital } \\
\text { Environmental Medicine } \\
\quad \text { Sub-Total }\end{array}$ & $\begin{array}{l}11,100 \\
11,200 \\
1,770 \\
24,070\end{array}$ & $\begin{array}{r}31,800 \\
29,500 \\
4,125 \\
65,425\end{array}$ & $\begin{array}{r}1,575 \\
1,3.30 \\
120 \\
3,025\end{array}$ & $\begin{array}{r}5,651 \\
5,562 \\
351 \\
11,564\end{array}$ \\
\hline Veterans Adm Hospital & & & & \\
\hline $\begin{array}{l}\text { Existing } \\
\text { Future } \\
\quad \text { Sub-Total }\end{array}$ & $\begin{array}{r}16,500 \\
\frac{4,130}{20,630}\end{array}$ & $\begin{array}{r}46,500 \\
11,620 \\
58,120\end{array}$ & $\begin{array}{r}1,200 \\
300 \\
1,500\end{array}$ & $\begin{array}{l}4,338 \\
1,084 \\
5,422\end{array}$ \\
\hline Charity Hospital & 40,000 & 220,000 & (3) 3,175 & (3) 10,644 \\
\hline Total & 121,620 & $4.18,175$ & 11,185 & 38,885 \\
\hline Design Capacity & (2) 121,500 & 418,175 & 10,000 & 38,885 \\
\hline
\end{tabular}

(1) Includes all steam and hot water requirements for all building functions except turbine-drive air conditioning equipment.

(2) Maximum Winter day demand at 7:00. A.M.

(3) Includes future conversion of existing local DX systems to chilled water served by central plant. 
TABLE XI

STEAM AND ELECTRICITY GENERATION

$\frac{\text { FUEL CONSUMPTION }}{\underline{1982}}$

1

2

3

COAL

FUEL

\begin{tabular}{cc}
$\begin{array}{c}\text { STEAM } \\
\text { GENERATED, }\end{array}$ & \begin{tabular}{c} 
ELECTRICITY \\
GENERATED, \\
POUNDS $\times 103$ \\
\hline
\end{tabular} \\
\hline
\end{tabular}

January

67,087

3,784

February 60,110

2,853

60,607

2,876

2,867

$3,4.63$

4,017

4,738

4,613

3,448

2,860

2,612

3,002

December $63,2.57$

TOTAL $\quad 854,043$

$40,52.9$

$3,021.4$
CONSUMPTION, TONS

$3,683.0$

$3,300.0$

$3,327.3$

$3,316.4$

$4,005.5$

$4,646.2$

$5,480.6$

$5,335.8$

$3,988.7$

$3,308.9$

$3,472.8$

$46,886.6$
4

GAS

FUJEL

CONSUMPTION, MCF

93,921

84,754

84,850

84,571

102,144

178,482

139,762

136,070

101,716

84,387

77,079

88,560

$1,195,660$

NOTES:

Cols. 1, 2, 3: From Stage 1 Report, P. 79

Col. 4: Col $1 \times 1.405$ 
TABLE XII

G.C. ICES

PROJECTED PLANT PRODUCTION

COAL FUEL steam

Steam

Demand

$\# / \mathrm{hr}$.
Year

1977

1978

1979

1.980

1981

1982

1983

1984

1985

1986

N 1987

1988
1989

1989
1990

1991

1992

1993

1994

1995

1996

1997

1998

1999

2000

121500
125730
130100
134630
139320
144160
149180
154370
159750
165300
171060
177010
183170
189540
196140
202970
210030
217340
224900

418175
434530
451520
469170
487510
506580
526380
546960
568350
590570
613670
637660
662590
688500
715420
743390
772460
802660
834050

10000

10425

38885

40520

42220

11330

43990

11811

45840

47770

51860

54040
56310

13382

13951

14544

15162

58680

15806

61140

63710

16478

17178
17908

66380

69170

18670

72080

75100

20290

78260

21152

81550

385550
400630
416300
432570
449480
467060
485320
504290
524020
544500
565800
587920
610900
634790
659610
657740
712200
740050
758990

5

Stm Gen

$\# \times 10^{3}$

7

8

Aux.

Cooling
$\# \times 10^{3}$.

Total

$\# \times 10^{3}$

9

9

$\begin{aligned} & 10 \\ & \\ & \text { Coal } \\ & \text { Fuel } \\ & \text { Cost } \\ & \$ / \text { Ton }\end{aligned}$

11

Total

Fuel

Coal

\$/Ton

$\$ \times 10^{3}$

Esc. 58

Note:

Col 1-4 From Table XI and Charts 1, 2, 3 in Stage I Report

Col $5=.922 \times \operatorname{Col} 2$

Col $6=\operatorname{Col} 4 \times \operatorname{Col} 10$

$\operatorname{Col} 7=(\operatorname{Col} 5+\operatorname{Col} 6) \times 10.38$

Col $8=\operatorname{Col} 5+\operatorname{Col} 6+\operatorname{Col} 7$

$\operatorname{col} 9=\frac{109.8 \times \operatorname{Col} .8}{2000}$

$\operatorname{col} 11=\operatorname{col} 9 \times \operatorname{col} 10$

$\begin{array}{lr}388850 & 79749 \\ 405200 & 83000 \\ 422200 & 86360 \\ 439900 & 89860 \\ 458400 & 93510 \\ 477700 & 97310 \\ 497700 & 101250 \\ 518600 & 105360 \\ 540400 & 109630 \\ 563100 & 114080 \\ 586800 & 118720 \\ 611400 & 123530 \\ 637100 & 128540 \\ 663800 & 133750 \\ 691700 & 139180 \\ 720800 & 141990 \\ 751000 & 140710 \\ 782600 & 156830 \\ 815500 & 153200\end{array}$

854043
888830
924860
962330
1001390
1042070
1084270
1128250
1174050
1221680
1271320
1322850
1376540
1432340
1490490
1520530
1613910
1679480
1747690

46886
48800
50770
52830
54980
57210
59530
61940
64450
67070
69790
72620
75570
78630
81830
83480
88600
92200
95950

58.43

61.35

64.42

67.64

71.02

74.57

78.30

82.22

86.32

90.64

95.17

99.93

104.93

110.18

115.68

121.47

127.54

133.92

2739.5 2993.8

3270.6

3573.5

3904.6

4266.1

4661.1

5092.7

5563.3

6079.2

6642.4

7257.3

7929.7

8664.0

9465.8

10139.9

11300.5

12347.8

13492.2

129384.2 
TABLE XIII

\section{GRID CONNECTED ICES \\ PROJECTED PLANT PRODUCTION \\ GAS FUEL}

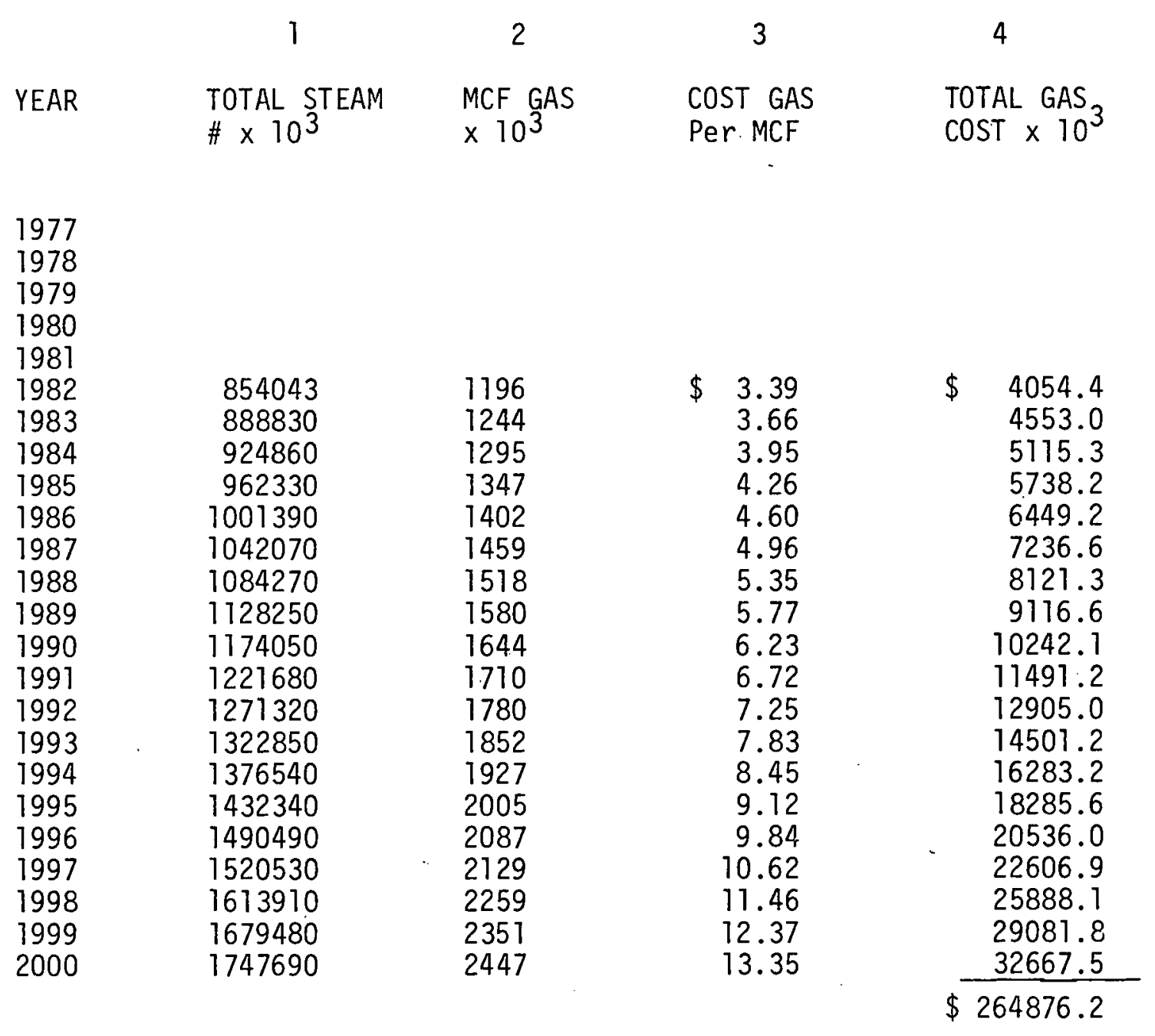

NOTES:

Co1. 1: From Table XII, Col. 8

Col. 2: Col. $1 \times 1.405 / 1000$

Col. 3: Escalation o 8\%/year

Col. 4: Col. $2 \times \mathrm{Col} .3$ 
TABLE XIV

G.C. ICES

PROJECTED PLANT PRODUCTION AND USE - COAL FUEL ELECTRICAL

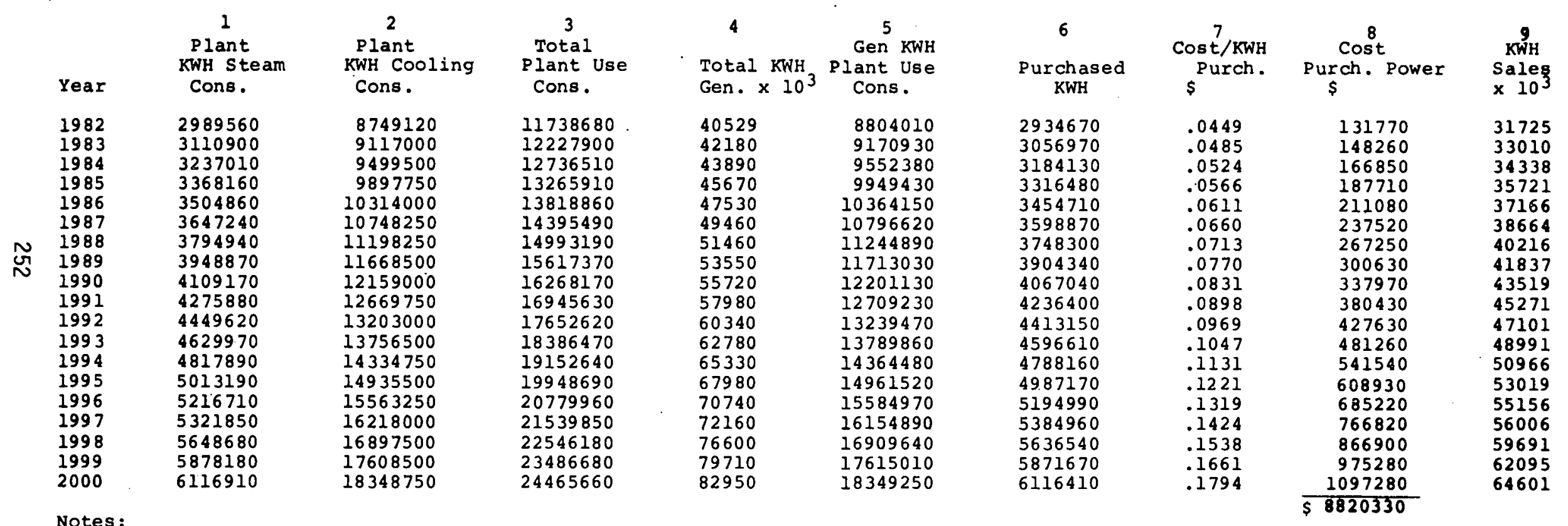

Col $1=350 \mathrm{KWH} / 100,000$ \#Steam (Col 8 Table XII)

Col $2=225 \mathrm{KWH} / 1000$ Tons (Col 4 Table XII)

$\operatorname{col} 3=\operatorname{col} 1+\operatorname{col} 2$

Col $4=\operatorname{Col} 8 \mathrm{Table} \times I / 21.07$

$\mathrm{Col} 6=258 \times \mathrm{Col} 3$

$\operatorname{Col} 8=\operatorname{Col} 6 \times \operatorname{Col} 7$

$\operatorname{Col} 9=\operatorname{Col} 4-\operatorname{Col} 5$ 
GRID CONNECTED ICES

PROJECTED PLANT PRODUCTION \& USE - GAS FUEL

ELECTRICAL

1
PLANT KWH
STEAM CONSUM.

STEAM CONSUM.

2
TOT. PLANT
CONSÜMTION

10457210
10894660
11349220
11822410
12316780
12832390
13366790
13925000
14507100
15113110
15745640
16402200
17087830
17800180
18544230
19259060
20125320
20967460
21844130

3
GEN. KWH
PLANT USE

7842910
8171000
8511920
8866810
9237590
9624290
10025100
10443750
10880320
11334830
11809200
12301650
12815870
13350140
13908170
14444300
15093990
15725600
16383100

4

PURCH. KWH

PLANT USE

2614300

2723660

2837300

2955600

3079180

3208100

3341690

3481250

3620780

3778280

3936440

4100550

4271960

4450040

4636060

4814760

5031330

5241860

5461030

\begin{tabular}{c}
5 \\
COST PURCH. \\
POWER \\
\\
\\
$\$ 117380$ \\
132100 \\
148670 \\
167290 \\
188140 \\
211730 \\
238260 \\
268060 \\
301390 \\
339290 \\
381440 \\
429330 \\
483160 \\
543350 \\
611500 \\
685620 \\
773820 \\
870670 \\
979710 \\
\hline 7870910
\end{tabular}

6 $\times 10^{3}$ $\times 10^{3}$

32686

34009

35378

36803

38290

39836

41435

43106

44840

46645

48531

50478

52514

54630

56832

57715

67506

63984

66567

NOTES:

Col. 1: $200 \mathrm{KWH} / 100,000 \#$ Steam (Col 8, Table XII)

Col. 2: Col. 1 + Col. 2, Table XIV

Col. 3: Col. $2 \times 75 \%$

Col. 4: Col. $2 \times 25 \%$

Col. 5: Col. $4 \times$ Col. 7, Table XIV

Col. 6: Col. 4, Table XIV - Col. 3 
TABLE XVI

SALES (CREDITS) FOR EXCESS POWER TO

UTILITY GRID

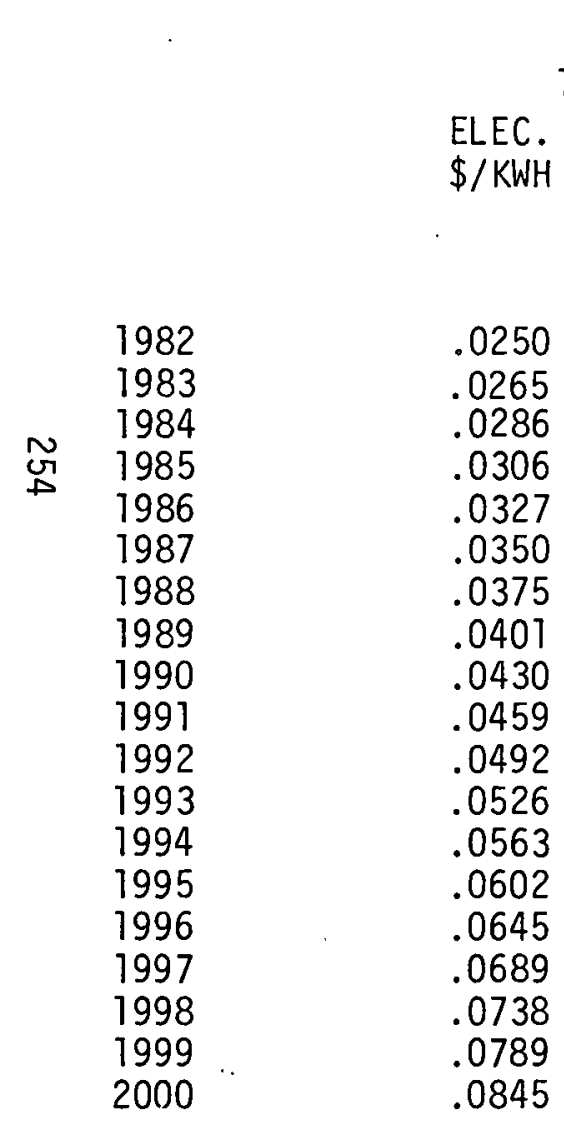

\begin{tabular}{lc}
\multicolumn{2}{c}{ GAS FUEL } \\
\hline 2 \\
$\times 10^{3}$ SALES & 3 \\
& SALES
\end{tabular}

\begin{tabular}{lc}
\multicolumn{2}{c}{ COAL FUEL } \\
\hline 4 \\
KWH SALES \\
$\times 10^{3}$
\end{tabular}

32686
34009
35378
36803
38290
39836
41435
43106
44840
46645
48531
50478
52514
54630
56832
57715
61506
63984
66567

$\begin{array}{r}817150 \\ 901240 \\ 1011810 \\ 1126170 \\ 1252080 \\ 1394280 \\ 1553810 \\ 1728550 \\ 1929120 \\ 2143800 \\ 2387720 \\ 2655140 \\ 2956540 \\ 3288730 \\ 3665660 \\ 3976560 \\ 4539140 \\ 5021770 \\ 5624910 \\ \hline 47,973,180\end{array}$

31725
33010
34338
35721
37166
38664
40216
41837
43519
45271
47101
48991
50966
53219
55156
56006
59691
62095
64601

793375

883020

982070

1093060

1215330

1353240

1508100

1667660

1871320

2080655

2317370

2576925

2869385

3191740

3557560

3858810

4405190

4903020

5458785

$\$ 46,596,620$

NOTES :

Col. 1: Escalation o $6 \% /$ Year

Col. 2: From Col. 6, Table XV

Col. 3: $\mathrm{Col} .1 \times \mathrm{Col} .2$

Col. 4: From Col. 9, Table XIV
Col. 5: Col. $1 \times$ Col. 4 
TABLE XVII

EXISTING PLANT SYSTEMS ENERGY

AND COST PROJECTION - GAS FUEL

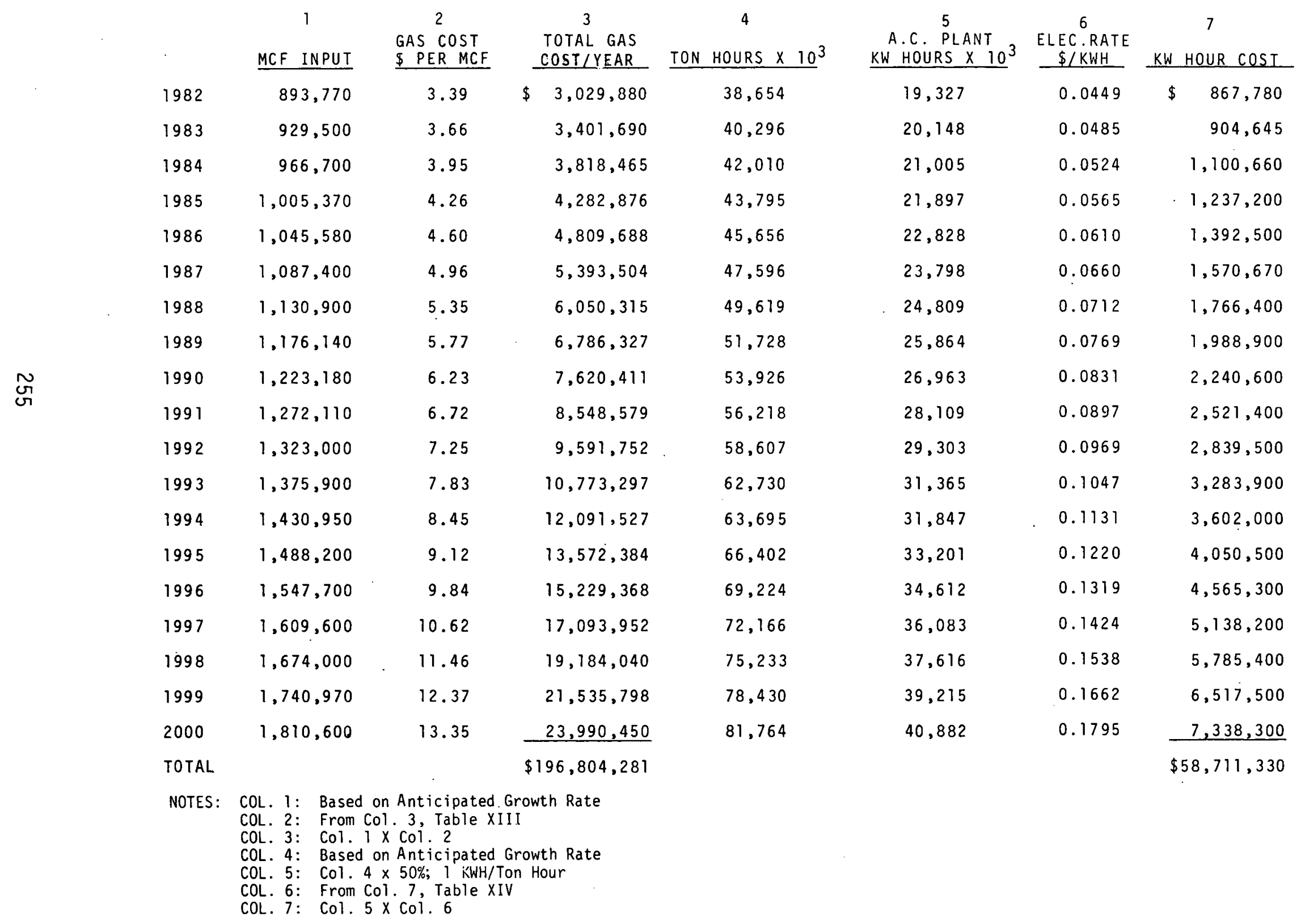


Energy cost saving as a result of the GC ICES concept versus an expanded plant system as is currently in use is as follows:

\section{EXISTING PLANT SYSTEMS ENERGY COSTS PROJECTED 1982 THROUGH YEAR 2000}

Gas Fue 1 Costs (Table XVII) \$196,804,281

Electrical Costs for Plant

operations (Table XVII)

TOTAL

$\frac{58,711,330}{\$ 255,515,617}$

GC ICES CENTRAL PLANT PROJECTED 1982 THROUGH YEAR 2000

Coàl Fuel Costs (Table XII)

$\$ 129,384,200$

Electrical Costs Served By

Purchased Power (Table XIV) Sub Total

$\frac{8,820,330}{\$ 138,204,530}$

Less Credit for Electrical

Energy Produced By Plant and

Sold (Table XVI)

$\$ 46,596,620$

TOTAL

$\$ 91,607,910$

Energy Cost Savings

Exist. Plants - Gas Fuel

And Electrical Energy (Table XVII)* $\$ 255,515,611$

GC ICES

Coal Fuel

$\$ 91,607,910$

SAVINGS

$\$ 163,907,701$

* Total column 3 plus total column 7. 


\section{ENERGY COST SUMMARY \\ GC ICES CENTRAL PLANT \\ PROJECTED 1982 THROUGH YEAR 2000 \\ GAS FUEL}

Fuel cost

(Table XIII)

Electrical Cost

Purchased Power

(Table XV)

Sub Total

Less Credit for

Electric Energy

Produced by Plant

\& Sold (Table XVI)

TOTAL ENERGY COST
$\$ 264,876,200$

$7,870,910$

$\$ 272,747,110$

$47,973,180$

$\$ 224,773,930$

ENERGY COST SAVINGS

Total Gas Fuel \&

Electric Energy

$\$ 224,773,930$

Total Coal Fuel \&

Electric Energy

(From preceding page)

$91,607,910$

Difference In Favor of Coal \$133,166,020 
TABLE XVIII

GC ICES

ENERGY INPUT COMPARISON

COAL FUEL VS. GAS FUEL

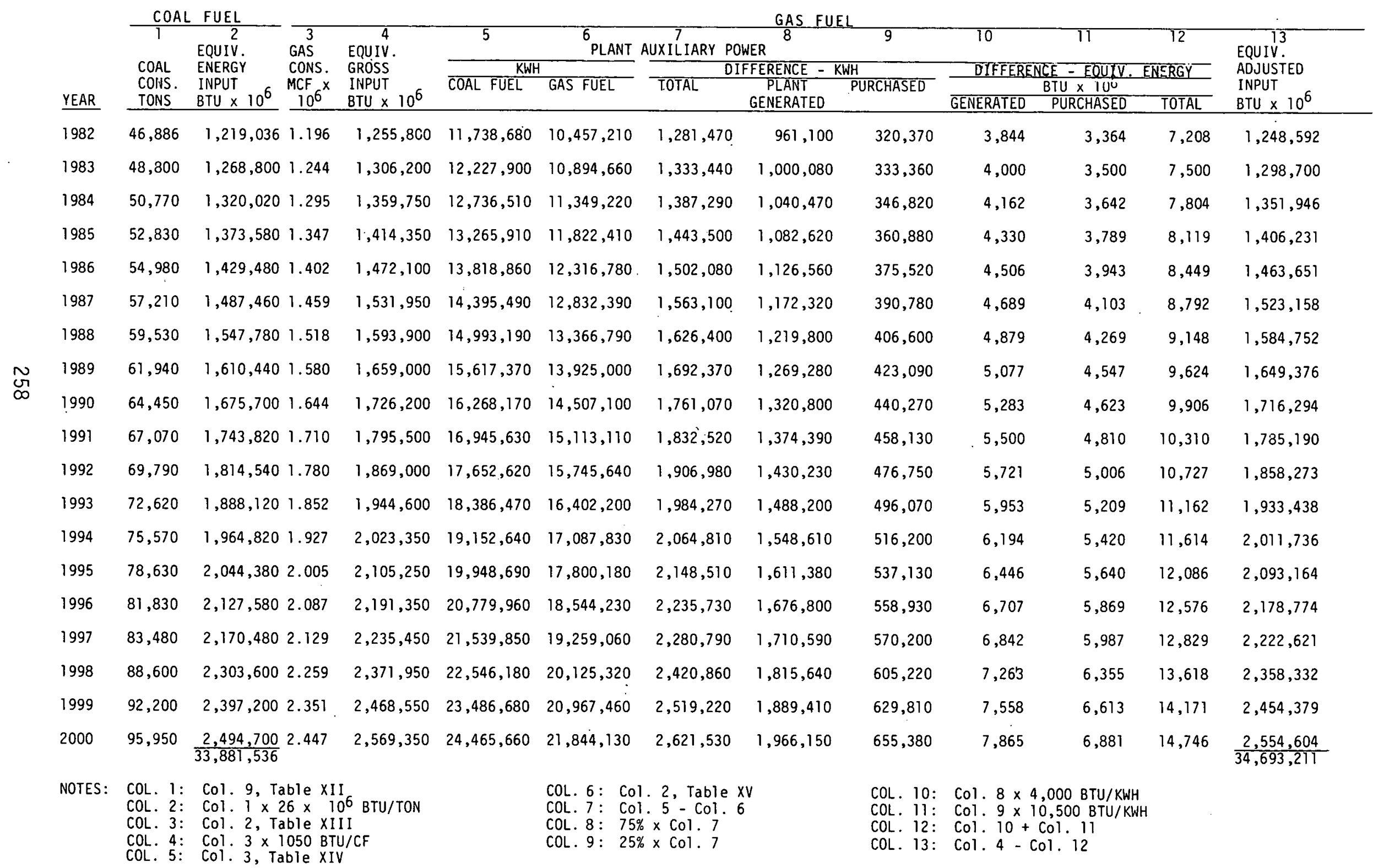




\section{4.b.6.3 Power Plant Building}

The Power Plant Building houses the boilers, refrigeration units, turbogenerators and all ancillary equipment as well as the offices and workrooms of the personnel operating the plant.

All types of enclosure materials utilized for the plant are represented on the elevation showing the cooling tower side of the building. (See Section 4.b.5).

From ground level to operating floor level (EI. 100) precast concrete panels are utilized for the exterior wall. These panels, textured to provide compatibility with the surroundings, also offer sound attenuation on the street level in order to make the plant acoustically acceptable.

Above the level of the operating floor the enclosure consists of long span, deep rib siding, in order to minimize the number and size of supports required for the gravity and wind loads of the walls. Since there will be a future need for occasional temporary removal of certain parts of the wall at this level for the exchange of tubes of the refrigeration units, etc., and installation of future equipment if so required, this type of exterior wall material is well suited at this plant elevation. If needed, acoustical liners can be attached to the siding to prevent the emanation of intolerable sound levels.

Since the plant building by its very nature is quite bulky, the color of the siding will be subdued and also in harmony with the dominant colors of the closer environment. The bold profile of the deep rib siding is also more in scale with the mass of the building than other, little textured surfaces would be.

The enclosure of the cooling towers will be provided by fixed louvers. These louvers will be fabricated from anodized aluminum, tentatively of a hue matching the anodized aluminum panels of the Superdome.

This type of louvers offers a long life span with minimum maintenance and will make the sizable exposed area of the cooling tower louvers as unobtrusive as possible.

An analysis of the different possible structural design alternates led to the choice of a steel framed building, which will be reacting lateral forces in conjunction with the reinforced concrete silo walls.

The choice of a steel structure will result in speedier erection, and, a fact which is often overlooked, in a residual value (scrap) after completion of its useful life.

The column loads are supported by concrete foundations resting on piles. The bay sizes are predicated, particularly those for the refrigeration units, on the largest unit sizes available on the market. The final determination of the buildings bay sizes will have to wait until the elements affecting the building design are known. 
Using the largest equipment sizes as the basis for the preliminary design will prevent the need to increase the building size during the final design. Perhaps a reduction in building size requirements will be possible.

The ground floor (E1. 84) will be constructed in concrete and designed to support 250 pounds/sq. ft. It consists of one way slabs and beams, and flat plate design to achieve the most economical layout.

The turbogenerator foundations and refrigeration unit foundations are separated from the ground floor in order to prevent any transmission of vibrations or loads. These foundations are constructed as reinforced concrete frames, designed to minimize the effects of possible vibrations and to avoid resonance. The foundation of the steel support structure from which the boilers are suspended is also separated from the ground floor slab.

The operating room floor (El. 100) is designed for a live load of 300\#/sq.ft. The concrete floor slab and the steel beams are designed for composite action ir order to minimize steel beam sizes and to reduce deflection. Monorails are provided over the refrigeration units and turbogenerators to assist in the removal of parts to be repaired or replaced. A floor hatch is provided to lower any parts to be removed to trucks located on the ground floor.

At this level, the floor is again separated from the turbogenerator and refrigeration unit supports, as well as from the boilers.

The other levels, shown on the structural framing drawings in Section 4.b.5, support either grating floors, roofs or concrete floors and are designed for live loads as required by the applicable codes. Wherever possible, the concrete slabs will be designed for composite action with the steel beams and roof joists for maximum economy.

The coal crusher and some coal handling facilities will be below grade and ground water level and thus walls and floors will have to be waterproofed. (Iridicated as El. 73 on the plans).

The coal and ash silo walls will be designed as reinforced concrete shear walls, in addition to serving their silo function. The interior faces of the ash silo walls will receive protection against the corrosive elements contained in the ashes.

The stack foundation will be 40 feet by 40 feet in size and five feet thick and will fit within building and property boundary lines.

The programmed expansion will take place at the northeast corner of the building. The affected foundations will be designed to support the future loads, primarily those of the cooling towers.

This will increase the initial construction somewhat, but will simplify the future, construction. 


\section{4.b.6.4 Thermal Energy Distribution Systems}

The piping systems for the thermal utilities will be welded steel pipe, carbon steel, seamless, A-53, grade B -- standard weight for chilled water and steam, extra heavy for condensate return.

A11 lines will be insulated and will have an external weatherproof jacket. Insulation on steam and condensate lines will be calcium silicate, or equivalent. Insulation on chilled water lines will be urethane, or equivalent.

System pipe sizes were based on the following limiting criteria:

Steam --- 0.8 psi drop/100 feet

Condensate --- 6 feet drop $/ 100$ feet; or $10 \mathrm{fps}$

Chilled Water -.- 8 feet drop/100 feet; or $10 \mathrm{fps}$ 


\section{4.b.6.5 Preliminary Structural Design For Steam \& Chilled Water Pipe} Distribution System Supports

\section{General Requirements}

Typical support to carry two chilled water lines ( $30^{\prime \prime} \emptyset \stackrel{+}{-}$ ), one steam line (12" \pm \pm ) and one condensate line (6" $\emptyset \pm)$. Span length of $30^{\prime} 0^{\prime \prime}$ is governed principally by limitations in the unsupported length of pipe. Supports will be sized to carry future elevated pedestrian walkway over pipes. Minimum vertical clearance in street of 15'6" must be maintained. Allowance must be made for extra length street crossing; however, these special designs will not be included here. Cost estimates will, however, take those into account. (See Typical Detail following for elevation of typical bent.)

Design Loads

The following design live and dead loads were used.

$$
\begin{array}{ll}
\text { Chilled water Lines (Fu11) } & -6001 \mathrm{~b} . / \mathrm{Ft} . \\
\text { Steam Line (Full) } & -1401 \mathrm{~b} . / \mathrm{Ft} . \\
\text { Condensate Line (Ful1) } & -901 \mathrm{~b} . / \mathrm{Ft} . \\
\text { Live Load-Walkway (Fu11) } & -1001 \mathrm{~b} . / \mathrm{Sq} \text {. Ft. } \\
\text { Live Load - Roof } & -201 \mathrm{~b} . / \mathrm{Sq} \text {. Ft. } \\
\text { Wind Load. } & -251 \mathrm{~b} . / \mathrm{Sq} . \text { Ft. }
\end{array}
$$

Design based on Working Stress Method (Reinf. Concrete Design Handbook ACI-SP-3) and requirements of New Orleans Building Code.

Preliminary Design Sizes (Refer to Typical Detail)

Concrete Floor Slab for Walkway - $\left(f^{\prime} c=3000\right.$ psi $)$ :

Thickness $=4^{\prime \prime}$

Steel Cross Beams (A36 steel):

Use w6x 20 @ 6'0" O.C. - Span = 14'0"

Steel Longitudinal Stringer (A36 Stee1):

Use $\mathrm{W} 24 \times 762$ ea. $\mathrm{W} / \mathrm{span}=30^{\prime} 0^{\prime \prime}$

Concrete Column and Bent Cap ( $f^{\prime} c=4000$ psi):

Cap Size - Depth Vảies as Shown - Thick. $=15^{\prime \prime}$

Column Size - Width Varies - Min. $=24^{\prime \prime}$ - Thick. = $15^{\prime \prime}$

Reinf. Steel ( $f s=24,000$ psi) $-10 \# 8$ and $6 \# 7$ bars

Foundation Design:

Footing $\left(f^{\prime} c=3000 \mathrm{psi}\right)-8^{\prime} 6^{\prime \prime} \times 5^{\prime} 6^{\prime \prime} \times 23^{\prime \prime}$

Piling - (Design Load $\left.=15^{\prime}\right)$

Use $6-50^{\prime} 0^{\prime \prime}$ Timber Piles 


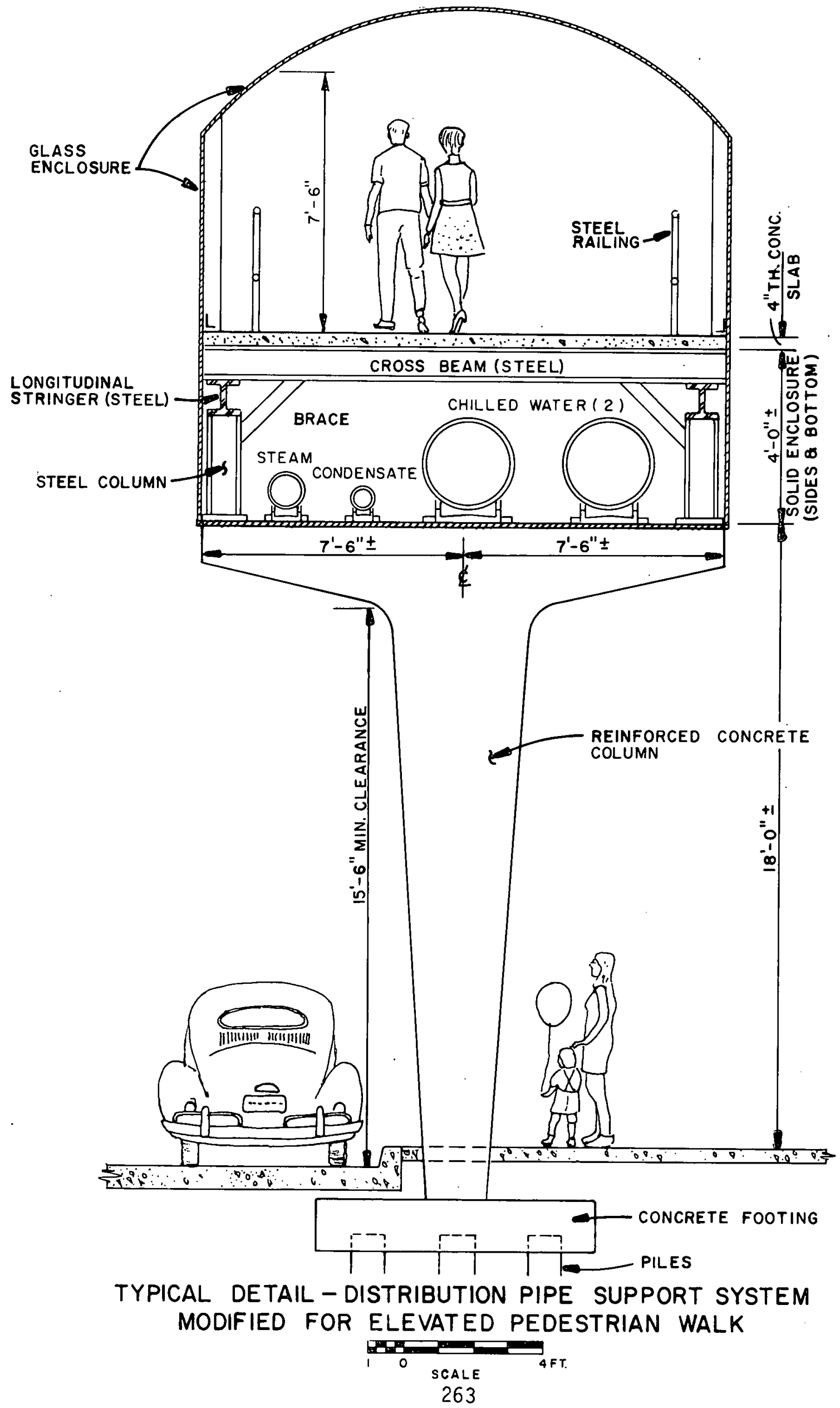




\section{5.b.1 FINAL PRELIMINARY DESIGN COST ESTIMATE}

\section{5.b.1.1 Estimate}

The table below presents the final preliminary design cost estimate based on material developed during the Phase II Study.

\section{TABLE XIX PLANT COST ESTIMATE}

Site Work

Building 2,078,660. cu. ft. a $\$ 1.50 / \mathrm{cu}$. ft.

$\$ 200,000$

$3,200,000$

870,000

Building and Equipment Piling

Boilers 2 \& 200,000\#/hr.

Scrubbers \& I.D. Fans \& Drives

Turbine Generator $9500 \mathrm{KW}$

Deaerating F.W. Heater and B. F. Pumps

Condensate Receivers \& Pumps

Steam \& Condensate Piping

Water Treatment Equipment

Misc. Equipment, Piping \& Controls

Coal Hopper Overhead

Coal Handling

Ash Handling

$0 i 1$ System, Burners, Tanks \& Piping

Stack 300'

Electrical Work

Refrigeration Units

Cooling Towers

Chilled Water, Condenser Water Pumps \& Piping

Subtotal

Contingencies $5 \%$

Subtotal

Escalation a $12 \%$

TOTAL PLANT COST

Distribution System

including contingencies \& escalation

Subtotal

Administration, Engineering, Construction Management, Legal, etc.

Total Construction cost

Land Cost

Total Cost for Bond Issue
$6,400,000$

$1,100,000$

$1,575,000$

170,000

50,000

$1,500,000$

150,000

425,000

55,000

350,000

225,000

200,000

350,000

$1,050,000$

$2,850,000$

750,000

$1,500,000$

$\$ 22,970,000$

$1,150,000$

$\$ 24,120,000$

$2,900,000$

$\$ 27,000,000$

$3,000,000$

$\$ 30,000,000$

$1,750,000$

$3,000,000$

$\$ 34,750,000$
$\$ 31,750,000$ 


\section{5.b.1.2 Sources of Cost Data}

The basic sources of cost data for this preliminary estimate are the manufacturers and suppliers of the specific equipment items listed. In some cases formal written preliminary quotations were obtained, and copies are included in the appendix.

Site work, building and piling estimates were obtained from professional estimators skilled in conceptual preliminary estimating.

Plant piping and miscellaneous items and electrical equipment, other than the turbine generator are based on percentages of costs for equipment served, connected motor horsepower, transformer capacity, etc., all as derived from past bid information, and cost breakdown on recent jobs of a similar nature.

In view of the rather extensive pricing information received over the course of several months the contingency item was reduced to $5 \%$ and the escalation percentage was increased to $12 \%$.

Cost for the piping distribution system mains was obtained from a local piping contractor. 
5.b.1.3 Items Required For ICES System But Not Included In ICES Capital Cost
a.) Electrical Grid-Connecting Sub-System
$\$ 725,000$
b.) ICES Branch Connections From Meter Points To Individual Building Mains, Including
Tie-Ins and Other System Adaptations

1) VA Hospital

$\$ 117,200$

2) Charity Hospital

108,100

3) EENT Hospital

22,450

4) LSU Medical Center
a.) School
b.) Residence Hall
106,500
c.) Basic Science
97,760
39,450
d.) Ambulatory Care
18,650

5.) Tulane Medical Center
a.) School
80,870
b.) Hospital
28,600 


\section{5.b.2 FINAL OPERATING \& MAINTENANCE COST ESTIMATE}

\section{5.b.2.1 General}

The following tables present the estimated annual costs for the ICES plant, based on updated data developed during preparation of the Phase II report; one table based on coal as boiler fuel, one based on natural gas as fuel.

\section{TABLE XX}

\section{ANNUAL OWNING - OPERATING COST - 1982}

COAL FUEL

Total Construction Cost, Including Land $\$ 34,750,000$

FIXED COSTS:

Depreciation, 30 yrs. (7)

Interest (1)

Total Fixed Cost

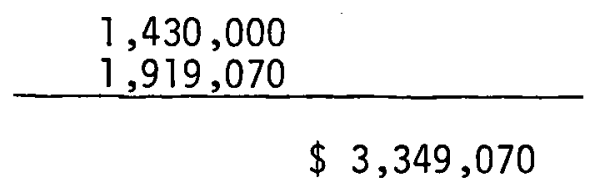

$2,739,700$

131,770

82,500

39,375

225,500

600,000

145,000

$\$ 3,963,845$

696,630

$\$ 4,660,475$

(3)

145,000

Subtotal, Operating Costs

$\$ 4,805,475$

TOTAL ANNUAL OWNING \& OPERATING COSTS

$\$ 8,154,545$ 
TABLE XXI

ANNUAL OWNING - OPERATING COST - 1982

GAS FUEL

TOTAL CONSTRUCTION COST INCLUDING LAND

$\$ 34,750,000$

Fixed Costs

Depreciation (1)

Interest (1)

$\$ 7,430,000$

$1,919,070$

$\$ 3,349,070$

Operating Cost

Fuel Gas 1,196,000 MCF

Q $\$ 3.39$

$\$ 4,054,000$

Purchased Electricity

$2,614,300 \mathrm{KWH} \odot \$ 4.49 \phi$

117,380

Water \& Sewer

61,875

Miscellaneous Supplies

29,530

Maintenance, Labor \&

Materials

169,125

Operating Labor

500,000

Insurance

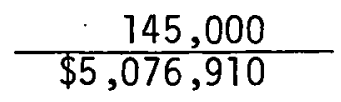

Management Fee

$$
\text { Sub Total }
$$

662,995

$\$ 5,739,905$

Grid Connection

Annual cost (3)

145,000

Sub Total Operating Costs

$5,884,905$

TOTAL ANNUAL OWNING \& OPERATING COSTS

$\$ 9,233,975$

NOTES (FOR BOTH TABLES):

(1) Plant depreciation revised to 30 years, based on a schedule prepared by HEAL Bond Counsel. (Copy of schedule included in Appendix).

(2) Management fee calculated at $\$ 500,000$ plus $18 \%$ of Operating costs, exclusive of fuel and purchased electricity.

(3) Inves tment of $\$ 725,000$ for electrical work to interconnect plant electrical output to NOPSI grid, estimated yearly cost, by NOPSI, at $\$ 145,000$. 


\section{5.b.2.2 Derivation}

The values appearing in preceding tables have been derived as follows:

\section{a.) Coal - Fuel Plant}

1.) Total Construction Cost as detailed in Section 5.b.7.

2.) Fixed Costs as prepared by Howard, Wei1, Labouisse, Friedrichs, Incorporated, Bond Counsel for HEAL (working draft copy in Appendix).

3.) Fuel cost, from Column 11, Table XII, Section 4.b.6.

4.) Purchased electricity, from Column 8, Table XIV, Section 4.b.6.

5.) Water \& Sewer, based on current city rates and estimated usage.

6.) Miscellaneous Supplies, estimated at $4.6 \$$ per $1000 \#$ steam generated.

7.) Maintenance Labor and Materials, as estimated by NOPSI.

8.) Operating Labor, as estimated by NOPSI.

9.) Insurance, estimated at $0.5 \%$ of plant construction costs.

10.) Management Fee, from NOPSI, based on $\$ 500,000$ per year plus $18 \%$ of all operating costs not including fuel or purchased electricity.

11.) Grid Connection Annual Cost, estimated annual cost on the investment of $\$ 725,000$ for grid connection, by NOPSI.

These estimated costs were made by personnel experienced in the operation and maintenance of similar facilities. However, there has been very little experience with the operation and maintenance of the flue gas scrubbing equipment now incorporated in this plant, reportedly a high maintenance item. The approximately $\$ 950,000$ per year included for operation and maintenance (I tems $5,6,7,8$ ) is slightly over $3 \%$ of the plant construction cost and would appear to be adequate. 
b. Gas - Fuel Plant

Items 1 and 2 - same as for coal fuel plant.

3 - Fuel cost from Column 4, Table XIII.

4 - Purchased electricity from Column 5, Table XV

5,6,7 - Water and Sewer, Miscellaneous Supplies, Maintenance Labor and Materials taken as 75\% of values shown for Coal - Fuel Plant.

8 - Operating Labor taken as $25 \times \$ 20,000$, or $\$ 500,000$ - 5 men less than used for Coal - Fuel Plant.

9 - Insurance, same as for Coal - Fuel Plant.

10 - Management Fee, same as for Coal - Fuel Plant.

11 - Grid Connection Annual Cost, same as for Coal - Fuel Plant.

271 


\section{5.b.3 FINAL FINANCIAL ANALYSIS}

The ICES financial analysis has been updated on the basis of refinements effected during preparation of the Phase II report. Table XXII, Financial Analysis for Year 1982, presents the anticipated financial picture for 1982 operation of the plant system, including comparative values between a coalfuel plant and a gas-fuel plant. Table XXIII, Projected Plant Cash Flow, and Table XXIV, Projected Plant Reserve Fund, present estimates of projections from 1982, the anticipated time for initial plant operation, through the year 2000.

The projections for estimated production of thermal utilities and electricity are presented in Section 4.b.6, Engineering Analyses: Table XII, Projected Plant Production, and Table XIV, Projected Plant Production and Use, Electrical -- both based on coal fuel. Comparative data for a gas-fuel plant appear in Tables XIII and XV.

Table XVI, Sales (Credits) for Excess. Power to Utility Grid, project to the year 2000 the estimated credits to be derived from delivering to the utility grid the anticipated excess electric power generated in the ICES plant.

The cost estimate of $\$ 34,750,000$ results in an annual fixed cost of $\$ 3,349,070$ based on a 30-year bond amortization period. As shown in Table XXII, the debt service ratio of 1.5 that would be required, in the opinion of bond counsel, in order to make the bond issue readily. salable raises the fixed cost to $\$ 5,023,600$. Adding the annual operating cost of $\$ 4,805,475$, the gross revenue required for the year 1982 becomes $\$ 9,829,075$. Annual sales at the assumed rates indicated yield a gross revenue of $\$ 9,808,330$, producing a surplus of $\$ 1,653,785$. The actual rates recommended may vary within limits; however, the gross revenue required must approach the $\$ 9,829,075$ figure. (Comparable data are also presented for a gas-fuel. plant in Table XXII.)

Using these data Table XXIII was developed to illustrate the cash flow through year 2000 and results in Table XXIV, Projected Reserve Fund. Placed at $6 \%$ interest compounded to the year 2000, this reserve fund would accumulate a total of $\$ 56,320,080$.

Realistically this reserve would be used to finance the plant expansions required. Assuming plant expansion in 1990-91 at a cost of $\$ 14,000,000$ and again in 1997 at $\$ 3,250,000$ the residual surplus account at year 2000 would be approximately $\$ 14,750,000$. 


\section{TABLE XXII}

FINANCIAL ANALYSIS FOR YEAR 1982

COAL

$\underline{\text { GAS }}$

Gross Revenue Required

Debt Service (1.5 ratio)

Operating Cost

$\$ 5,023,600$

$\$ 5,023,600$

$\underline{4,805,475}$

$\underline{5,884,905}$

Total

$\$ 9,829,075$

$\$ 10,908,505$

Annual Sales

Steam, Pounds

Chilled Water, Ton Hours

$\$ 418,175,000$

$38,885,000$

$\$ 418,175,000$

$31,735,000$

$38,885,000$

Electricity, KWH

Assumed Average Sales Rates

Steam, $\$ / 1000$ pounds

$\$ 5.75$

$\$ 0.77$

$\$ 0.025$

$\$ 6.70$

Chilled Water, $\$ /$ ton hour

Electricity, $\$ / \mathrm{KWH}$

$\$ 0.1875$

$\$ 0.025$

Estimated Revenues

Steam

Chilled Water

Electricity

$\$ 2,404,505$

$6,610,450$

$\$ 2,801,772$

$7,290,937$

793,375

817,150

Total 1982 Revenue

$\$ 9,808,330$

$\$ 10,909,859$

The estimated revenues are reasonably close to the gross revenue required for each fuel system analyzed. 
TABLE XXIII

G.C. ICES

PROJECTED PLANT CASH FLOW

COAL FUEL

\begin{tabular}{|c|c|c|c|c|c|c|c|c|c|c|c|c|c|c|}
\hline ea & $\begin{array}{c}1 \\
\text { Coal } \\
\$^{x} 10^{3}\end{array}$ & $\begin{array}{c}2 \\
\text { Cost } \\
\text { Purch. } \\
\text { KWH } \\
\$\end{array}$ & $\begin{array}{l}\quad 3 \\
\text { Water } \\
\text { and } \\
\text { Sewer } \\
\$\end{array}$ & $\begin{array}{l}\text { Misc. } \\
\text { Supp. } \\
\$\end{array}$ & $\begin{array}{l}\quad 5 \\
\text { Mainte- } \\
\text { nance } \\
L \& M \\
\$\end{array}$ & $\begin{array}{l}\quad 6 \\
\text { Opera- } \\
\text { ting } \\
\text { Labor } \\
\$\end{array}$ & $\begin{array}{l}\text { Insurance } \\
\$\end{array}$ & $\underset{\$}{\text { Total }}$ & $\begin{array}{c}9 \\
\substack{\text { Manage- } \\
\text { ment }}\end{array}$ & $\begin{array}{l}\quad 10 \\
\text { Grid } \\
\text { Annual } \\
\text { Cost } \\
\$\end{array}$ & $\begin{array}{l}11 \\
\text { Total } \\
\text { Operating } \\
\$\end{array}$ & $\begin{array}{l}12 \\
\text { Total } \\
\text { Fixed } \\
\$\end{array}$ & $\begin{array}{l}13 \\
\text { Total } \\
\text { Own \& } \\
\text { Oper. } \\
\$\end{array}$ & $\begin{array}{c}14 \\
\text { Gross } \\
\text { Rev. } \\
\text { Req. } \\
\$\end{array}$ \\
\hline & & & 58 & 58 & 68 & 78 & $21 / 28$ & & & & & & & \\
\hline $\begin{array}{l}1982 \\
1983 \\
1984 \\
1985 \\
1986 \\
1987 \\
1988\end{array}$ & $\begin{array}{l}2739.5 \\
2993.8 \\
3270.6 \\
3573.5 \\
3904.6 \\
4266.1 \\
4661.1 \\
5092.7\end{array}$ & $\begin{array}{l}131770 \\
148260 \\
166850 \\
187710 \\
211080 \\
237520 \\
267250 \\
300630\end{array}$ & $\begin{array}{r}82500 \\
86630 \\
90960 \\
95500 \\
100280 \\
105290 \\
110560 \\
116090\end{array}$ & $\begin{array}{l}39375 \\
41340 \\
43410 \\
45580 \\
47860 \\
50250 \\
52770 \\
55400\end{array}$ & $\begin{array}{l}225500 \\
239030 \\
253370 \\
268570 \\
284690 \\
301770 \\
319880 \\
339070\end{array}$ & $\begin{array}{l}600000 \\
642000 \\
686940 \\
735020 \\
786480 \\
841530 \\
900440 \\
963470\end{array}$ & & $\begin{array}{l}3963845 \\
4299660 \\
4664430 \\
5061980 \\
5494990 \\
5966460 \\
6480200 \\
7039760\end{array}$ & & $\begin{array}{l}145000 \\
145000 \\
145000 \\
145000 \\
145000 \\
145000\end{array}$ & & & & $\begin{array}{r}9829075 \\
10176630 \\
10553890 \\
10964720 \\
11411870 \\
11898370 \\
12428130 \\
13004720\end{array}$ \\
\hline $\begin{array}{l}1990 \\
1991 \\
1992 \\
1993 \\
1994 \\
1995 \\
1996 \\
1997 \\
1998\end{array}$ & $\begin{array}{r}556 \\
607 \\
664 \\
725 \\
792 \\
866 \\
946 \\
1013 \\
1130 \\
1234\end{array}$ & $\begin{array}{l}337970 \\
380430 \\
427630 \\
481260 \\
541540 \\
603930 \\
685220 \\
766820 . \\
866900 \\
975280 \\
1097280\end{array}$ & $\begin{array}{l}121890 \\
127980 \\
134380 \\
141100 \\
148160 \\
155570 \\
163340 \\
171510 \\
180090 \\
189090 \\
198550\end{array}$ & $\begin{array}{l}58170 \\
61080 \\
64140 \\
67340 \\
70710 \\
74250 \\
77960 \\
81860 \\
85950 \\
90250\end{array}$ & $\begin{array}{l}359410 \\
380980 \\
403840 \\
428070 \\
453750 \\
480980 \\
509830 \\
540420 \\
572850 \\
607220 \\
643650\end{array}$ & $\begin{array}{l}1030910 \\
1103070 \\
1180290 \\
1262910 \\
1351310 \\
1445910 \\
1547120 \\
1655420 \\
1771300 \\
1895290 \\
2027960\end{array}$ & $\begin{array}{l}176700 \\
181100 \\
185600 \\
190300 \\
195000 \\
199900 \\
204900 \\
210000 \\
215300 \\
220600 \\
226200\end{array}$ & $\begin{array}{r}7648350 \\
8313840 \\
9038280 \\
9828280 \\
10690170 \\
11629540 \\
12654170 \\
13565930 \\
14992890 \\
16325530 \\
17780600\end{array}$ & $\begin{array}{l}70 \\
60 \\
80 \\
50 \\
10 \\
90 \\
70 \\
60 \\
90 \\
40 \\
00\end{array}$ & & $\begin{array}{r}86 \\
92 \\
100 \\
108 \\
117 \\
126 \\
137 \\
146 \\
161 \\
175\end{array}$ & & $\begin{array}{l}11 \\
12 \\
13 \\
14 \\
15 \\
16 \\
17 \\
18 \\
19 \\
20 \\
22\end{array}$ & $\begin{array}{l}13631420 \\
14316200 \\
15061160 \\
15873030 \\
16758180 \\
17722330 \\
18773340 \\
19713190 \\
21170080 \\
22534570 \\
24023600\end{array}$ \\
\hline
\end{tabular}

Notes:

Col $1=$ col 11 Table XII

Col $2=$ Col 8 Table XIV

Col $9=188 \times(\operatorname{Col} 3+4+5+6+7)+\$ 500,000$

$\operatorname{Col} 11=\operatorname{Col} 8+\operatorname{Col} 19+\operatorname{Col} 10$

$\operatorname{col} 14=\operatorname{col} 11+(\operatorname{Col} 12 \times 1.5)$ 
TABLE XXIV

PROJECTED PLANT RESERVE FUND

COAL FUEL

1

Annual

Margin

$\$$

1.674530

1674530

1674530

1674530

1674530

1674530

1674530

1674530

1674530

1674530

1674530

1674530

1674530

1674530

1674530

1674530

1674530

1674530

1674530
2

Annual

6\% Int.

$\$$

100470

206970

319860

439520

566370

700820

843340

994410

1154550

1324300

1504230

1694950

1897120

2111420

2338580

2579360

2834500

3105140
3

Accumulated

Reserve

$\$$

1674530

3449530

5331030

7325420

9439470

11680370

14055720

16573590

19242530

22071610

25070440

28249200

31618680

35190330

38976280

42989390

47243280

51752410

56532080

Column $1=\operatorname{Col} 14-\operatorname{Col} 13$, Table XXIII 


\section{5.b.4 DOE-FUNDING PROPOSAL}

It is proposed that DOE provide funding for items 1 isted below and grouped by phases. Justification references are related to ERDA (now DOE) RFP Fo. E (11-1) P-76-0016, page I-6.

PHASE

I I I

$$
\begin{aligned}
& \text { Stack Monitoring and Control } \\
& \text { Operation \& Maintenance Procedure } \\
& \text { Operation \& Maintenance Manuals } \\
& 1 / 2 \text { of Travel, Per Diem, Printing } \\
& \text { Sub-Total, Phase III }
\end{aligned}
$$

IV Special Instrumentation \&

$$
\text { Monitoring (MIS) }
$$

Trave1, Per Diem, 1/2 of Printing

Sub-Total, Phase IV

$\checkmark \quad$ Initial Operation, Testing, Monitoring of MIS

Environmental Testing

Travel, Per Diem, Printing

Installation \& Start-up Report

Sub-Total, Phase V

VI Long-Term Operation \& Evaluation
Justification

RFP Para.No. EST. COST
$\$ 10,000$

20,607

32,279

24,300

$\$ 87,186$

IV (2)

IV (4)

150,000

11,200

161,200

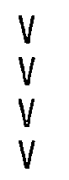

70,414

32,000

8,600

73,142

184,156

VI

64,512 per year 
APPENDIX $\quad A-1$

LETTER TO IRS RE BONDS' TAX-EXEMPT STATUS 
HAROLO B. JUDELL WILLLAM H. BECK. JR. LONNIE L. BEWLEY J. MUGH MARTIN

CARL GRANT SCMLUETER SUSAN WEEKS ANTHONY
FOLEY JUDELL BECK BEWLEY \& MARTIN

ATTORNEYS AND COUNSELLORS AT IAW

SUTTE 2000 225 BARONNE STREKT

NEW ORLEANS. LA. 70112

TELEPBONE (504) 588-1249

September 20, 1978

Commissioner of Internal Revenue

1111 Constitution Avenue

Washington, D.C. 20224

Attention: $T: P S: T$

Re: Health Education Authority of Louisiana Grid Connected Integrated Community Energy Station

Dear Sir:

On behalf of the Health Education Authority of Louisiana (the "Authority"), we respectfully request your rulings concerning the Federal income tax status under Section 103(b) of the Internal Revenue Code of 1954, as amended (the "Code"), (i) of certain grid connected integrated community energy system facilities (the "Project") to be financed by the Authority and (ii) of certain bonds to be issued by the Authority in connection therewith (the "Bonds"), all as more fully described herein.

\section{The Parties}

The Authority

The Authority is a body corporate and public, constituting an instrumentality of the State of Louisiana. The Authority was created and exists pursuant to Act 112 of the Regular Session of the Legislature of Louisiana for the year 1968, as amended (the "Act"), which Act as amended now appears as La. R.S. 17:3051 to La. R.S. 17:3060, inclusive. The Authority's address is Room 213, State Office Building, 325 Loyola Avenue, New Orleans, Louisiana 70112. 
Commissioner of Internal Revenue $\quad-2-\quad$ September 20, 1978

The Authority was created for the purpose of operating a cooperative and coordinated multi-institutional medical complex, the Louisiana Medical Complex at New Oxleans, that will serve to attract, encourage and assist public and private institutions and organizations that are dedicated to exemplary patient care, health science education and biomedical research, as well as organizations providing facilities and/or services deemed appropriate by the Authority, to locate and/or operate in a functional geographic relationship with said complex.

To accomplish the purposes of the Act, the Authority, through and by its Board of Trustees (the "Board"), is empowered to designate specified institutions as participating institutions, to employ engineers, architects, attorneys and other employees, to make contracts, to acquire real or personal property, to sell or lease or otherwise dispose of real or personal property, to solicit and accept federal, state or local grants, to exercise the power of eminent domain within the limits of the medical complex, and to issue bonds and certificates of indebtedness. Pursuant to the Executive Reorganization Act, Act 83 of 1977, the Authority was transferred to the Department of Health and Human Resources. Pursuant to said Act, the Authority retains all policy making, ruling making and licensing powers but the administration and implementation of the policies, rules and decisions of the Authority is vested in the Secretary of the Department of Health and Human Resources. 
NOPSI

New Orleans Public Service Inc. ("NOPSI") is a Louisiana corporation. NOPSI's address is 317 Baronne Street, New Orleans, Louisiana 70112. NOPSI is a public utility company operating under a franchise from the City of New Orleans and provides electrical, gas and transit serviœ to the public within the city limits of the City of New Orleans (which city limits are co-extensive with the boundaries of the Parish of Orleans). NOPSI is a subsidiary of Middle South Utilities Inc. which owns one hundred percent of NOPSI's common stock. NOPSI files its Federal income tax returns under the audit jurisdiction of the District Director of the Internal Revenue in Austin, Texas. Its Employer Identification Number is 72-027-3040.

\section{Description of the Project}

The Project is a central energy plant which is currently being studied by the Authority under sponsorship of the United States Department of Energy to serve the combined thermal needs, specifically, steam for heating and miscellaneous usages and chilled water for air conditioning, of five medical institutions in the Louisiana Medical Complex. These institutions consist of two state institutions, namely Charity Hospital of Louisiana and Louisiana State University Medical Center, and three non-profit or Federal institutions, namely Tulane University Medical Center, Eye and Ear Institute of Louisiana and Veterans Administration Hospital (collectively, the "Institutions"). 
The Project designers propose to utilize multiple-fuel fired (natural gas, oil, coal, processed waste) steam boilers providing high-pressure steam to a non-condensing turbine generator for producing electrical power. Steam exhausted at a lower pressure from the generator turbine will serve the direct steam needs of the Institutions and also drive a turbine on each of three centrifugal chilled water refrigeration machines in the central plant to satisfy comfort 000 ling and dehumidification requirements of such Institutions.

Initially, the Project will include two 200,000 pound per hour steam generating capacity boilers, which will, for a number of years, provide sufficient steam capability even with one unit out of service. With the growth of the Complex an additional boiler will be needed.

The steam, at 1,250 pounds per square inch pressure, 950 degrees $\mathrm{F}$. temperature characteristics, will normally flow to the non-condensing steam turbine, driving an electric generator rated at 9,500 $\mathrm{kw}$. However, the steam output of this turbine at 185 pounds per square inch pressure is governed by the steam requirements of the chilled water refrigeration machines, and to the actual steam needs of the Institutions. If the steam from the turbine generator is insufficient, there is provided a pressure reducing and desuperheating station which by-passes the turbine. The exhaust of each chilled water turbine will be used for heating purposes in the Institutions and for plant usage. Each of the chilled water units is rated at 5,000 tons per hour of chilled water, which will be sent to the Institutions at 40 degress F., and estimated to be returned to the chillers at 55 degrees $F$. 
Commissioner of Internal Revenue -5- September 20, 1978

The plant will include the necessary feedwater heating facilities for the boilers to assure high operating efficiency. It is anticipated that scrubbers will be needed for coal operation to assure that requirements of the various environmental agencies are fully met. Also, fly ash collectors will be installed. Adequate coal storage will be provided and coal will be hauled to the plant by closed trucks from an existing coal storage facility on the Gulf Seaway in New Orleans East. Ashes will also be hauled away to dumps in closed trucks.

A complete fuel oil facility will be provided, with the necessary burners, heaters, pumps and controls. Natural gas supply will be from the NOPSI system, with pressure reducing and regulating equipment, metering and control systems. It is anticipated that the furnaces of the boiler units will be designed to also handle and bum processed wastes, with an external unit to prepare these wastes.

Piping systems will distribute the lower pressure steam and chilled water from the plant to the different buildings of the Institutions. Condensate and water will be returned to the plant. The piping systems will consist, generally, of elevated steel pipe systems, insulated as required for the particular service and service conditions. It is intended that the structures could eventually be overhead walkways facilitating pedestrian traffic in this crowded area. Metering stations for each system will be provided at each building to be served.

Electrical energy will be generated through the operation of the thermal plant operation. The electrical energy will enter the electrical power 
grid of NOPSI which serves the electrical customers of NOPSI (except as needed to operate the Project). The amount of electricity produced will be governed by the combined demands of the thermal elements - chilled water and lower pressure steam. The primary connection to the utility company electrical grid will be through a 13.8 to $24.0 \mathrm{kv}$. transformation from the turbine generator output to the NOPSI Derbigny Station. A secondary connection at $13.8 \mathrm{Kv}$. will be made to the NOPSI Notre Dame Station. Both connections to the grid will be equipped with in-and-out metering. A redundant transformer will be provided at the Central Plant. A design description of the Project which outlines the proposed design and operation of the Project and a cost estimate of component parts of the Project are attached hereto as Exhibit A.

\section{Summary of the Transaction}

The Authority proposes to acquire and construct the Project and to finance the cost of such acquisition and construction through the issuance of not exceeding $\$ 45,000,000$ of its revenue bonds (the "Bonds"). Prior to the commencement of construction or aoquisition of the Project or any part thereof, the Authority will adopt a resolution undertaking to issue the Bonds in an aggregate principal amount up to $\$ 45,000,000$ in accordance with the United States Treasury Regulations, Section $1.103-8(a)(5)$. Pursuant to the terms and provisions of a lease-operating agreement (the "Lease Agreement"), by and between the Authority and NOPSI, the Authority proposes to issue and sell the Bonds in aggregate principal amount sufficient to enable it to pay the cost of constructing and equipping the Project, including the cost of acquisition of the site of the Project and the design and construction of the Project, the 
costs and expenses incurred in connection with the issuance of the Bonds, and other costs and expenses in connection with the Project. By the tenms of the Lease Agreement, NOPSI will own the steam, chilled water and the electricity produced by the Project, as well as the electrical distribution facilities. Pursuant to the Lease Agreement, the Authority proposes to lease the Project to NOPSI at a rental calculated as a percentage of the gross receipts received by NOPSI arising out its management and operation of the Project. The management, operation, maintenance and possession of the Project will rest with NOPSI during the term of the Lease Agreement. The Bonds will be secured by a pledge of the rentals payable by NOPSI pursuant to the Lease Agreement. Pursuant to the terms of one or more service agreements (the "Service Agreement"), it is proposed that NOPSI furnish the steam and chilled water produced by the Project to one or more of the Institutions at rates calculated in accordance with Article 18 of the Service Agreement. The Service Agreement specifically provides that the Institutions may not resell, share, remeter or otherwise furnish steam and chilled water to others, with the exception that the Institutions may furnish steam or chilled water to tenants on their premises if no specific charge is made therefor. Drafts of the proposed form of Lease Agreement and Service Agreement are attached hereto as Exhibits " $B$ " and " $\mathrm{C}$, respectively.

\section{Applicable Law and Discussion}

Section 103(a) of the Code exempts from taxation the interest on obliga-... tions of a state or a political subdivision thereof. This general rule is made specifically inapplicable to those obligations that are industrial development bonds by Section 103(b)(1). However, Section 
Commissioner of Internal Revenue -8- September 20, 1978

$103(b)(4)$ provides exemptions from taxability for the interest on certain types of industrial development bonds.

It is clear by the terms of the act creating the Authority that the Authority is an agency of the State of Louisiana within the meaning of Section 103 of the Code. Under Section $103(b)(4)(E)$ of the Code, interest on industrial development bonds substantially all the proceeds of which are to be used to provide "facilities for the local furnishing of electric energy" shall rot be included in the gross income of the recipient. In order to qualify for "exempt facilities" treatment, the output of an electrical energy facility must be available on a regular basis for general public use. (T.Reg. Section 1.103-8(a)(2)). A facility for the local furnishing of electric energy will satisfy the public use requirement if:

"a) the owner or operator of the facility is obligated, by a legislative enactment, local ordinance, regulation, or the equivalent thereof, to furnish electric energy... to all persons who desire such services and who are within the service area of the owner or operator of such facility, and b) it is reasonably expected that such facility will serve or be available to a large segment of the general public in such service area." (T.Reg. Section 1.103-8(f)(1)(ii))

As the description of the Project indicates, the production of electrical energy constitutes a significant part of the Project as the Project will generate electricity for use in NOPSI's electrical power grid and, thus, the Project should be considered to be a facility for the furnishing of electrical energy. The "public use" test is met as NOPSI has received from the City of New Orleans indeterminate permits for the operation of its electrical department, and the electrical energy which is produced by the Project enters the NOPSI grid and it is 285 
distributed to the general public within the service area of NOPSI. NOPSI does not supply electrical energy or gas to any parish other than Orleans Parish, except as part of its interchange obligations.

In the alternative, if you should find that only those portions of the Project which are specifically related to the production of electrical energy qualify for tax-exempt financing pursuant to Section $103(b)(4)(E)$, it is submitted that the remaining portions of the Project will qualify for tax-exempt financing by virtue of the fact that those remaining portions will be used to produce steam and chilled water which are to be furnished solely to non-profit or governmental institutions. Consequently, bonds issued to finance those portions of the Project which produce steam or chilled water would not constitute "industrial development bonds" as the proceeds of the bonds would not be used in the trade or business of a "non-exempt" person but would be used to construct a project for the production of steam and chilled water used in the trade or business of exempt institutions. As indicated above, all steam or chilled water produced by the Project will be supplied to one or more of the Institutions and the Institutions are specifically prohibited by the terms of the Service Agreement from furnishing this steam or chilled water to any other party.

\section{Ruling Requested}

Based upon the above facts and representations, we respectfully request your ruling as follows: 
Commissioner of Internal Revenue -10- September 20, 1978

1. The Bonds to be issued by the Authority will be considered to have been issued by or on behalf of the State of Louisiana or an agency thereof.

2. Interest paid on the Bonds will be excludable from gross income of the holders thereof under Section $103(a)(1)$ of the Code.

To the best of our knowledge and belief, the identical issues involved in this request are not pending before an Internal Revenue Service field office in connection with an active examination or audit of a tax return already filed nor are such issues being considered by a branch office of the Appellate Division.

A conference is requested if consideration is given to reaching a onclusion adverse or inconsistent with the requested ruling set forth herein. A power of attorney authorizing the undersigned to represent the Authority in connection with this request is enclosed herewith.

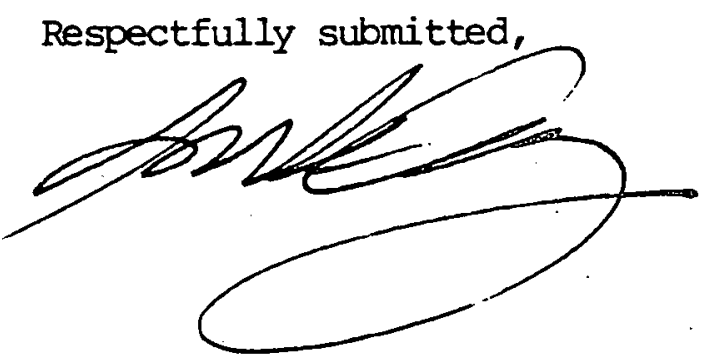




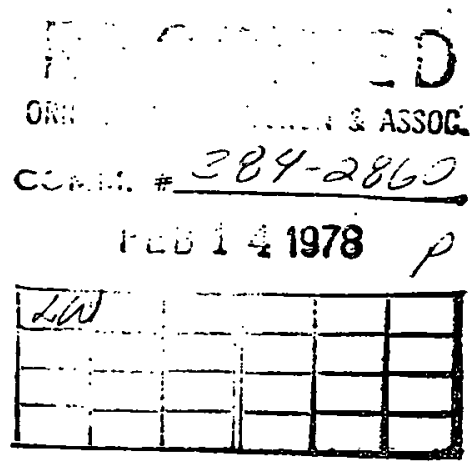

Mr. L. Whalen

Orr-Schelen-Mayeron and Associates

2021 Hennepin Ave. E.

Minneapolis, MN 55413

Subject: $200,000 \mathrm{lb} / \mathrm{hr}$ Steam Generator

$\mathrm{SO}_{2}$ and Particulate Scrubber Estimate

Louisiana Heälth and Education Department

New orleans, Louisiana

Dear Larry:

Here is our estimate from Peabody Air Resources Equipment Group, Peabody International, Inc. , based on information regarding fuels and cleaning requirements we discussed.

User will burn Eastern Kentucky coal at $12,80.0$ BTU/1b, 48 ash and 0.8 to $1.05 \%$ sulfur, or compliance coal from oklahoma. Boiler makes 138,500 ACFM of flue gas at $675^{\circ} \mathrm{F}$. when burning this fuel.

Alternately, Eastern Montana coal of $0.8 \% \mathrm{~S} 2$ but $8600 \mathrm{BTO} / 1 \mathrm{~b}$ may be used but will produce considerably greater flue gas volume which we ask be calculated and advised us for our revision of sizing if necessary.

The scrubber would be approximately $\$ 110,000$ in high moly 316L stainless steel with a slot tray (or an external venturi if they prefer) followed by an impingement tray in turn followed by an $\mathrm{SO}_{2}$ absorption tray. A solids-settling clarifier would cost approximately $\$ 28,000$ and the pumps approximately $\$ 14,000$. A control center with standard instruments would be approximately $\$ 18,000$. They would add sodium carbonate from a carbon steel mix tank (buying the carbonate dry) from which they would meter it into the scrubber on demand. This feed unit would be about $\$ 22,000$.

That gives a "system" budgetary price of approximately $\$ 192,000$ for equipment, and $\$ 200,000$ to $\$ 250,000$ installed.

We can follow-up at a later date with a detailed quotation when desired. The above described equipment will meet the performance requirements you described.

Córdially,

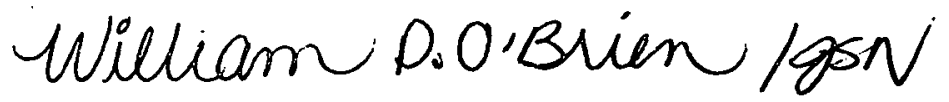

William D. O'Brien, P.E. 


\section{(ه) GOULDS PUMPS. INC. \\ SBNECA FALLS NEW YORK 13148}

\section{CENTRAFUGAL PUMP}

\section{QUOTATION}

\section{REPLY TO: \\ EDERMANN \& ASSOCIFTES IIC.}

3837 Republic Ava

Minneapolis, MN 65426

Phone: AC 612-927-4364 TLX 29-0874
To: OSi:

2021 Dast llennepin

Suite 28

iinneapolis, in 55413
Date: $2 / 13 / 78$

Proposal No.: $731: 23922$
All quotations subject to terms and conditions on the reverse side except

as noted on Page attached.

SHIPMENT: Oyr best estimate at this time is $24-20$ weeks after com plete englneering and manufacturing information and full approval to proceed with work.

Page: 1 of 4

Attention: irs. L. ifialen Inquiry Date:

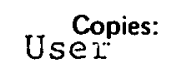

Usei:

Nanc:

Fi: Al futhority

Inquiry No.:

In answer to your inquiry, we propose to furnish GOULDS PUMPS as described below:

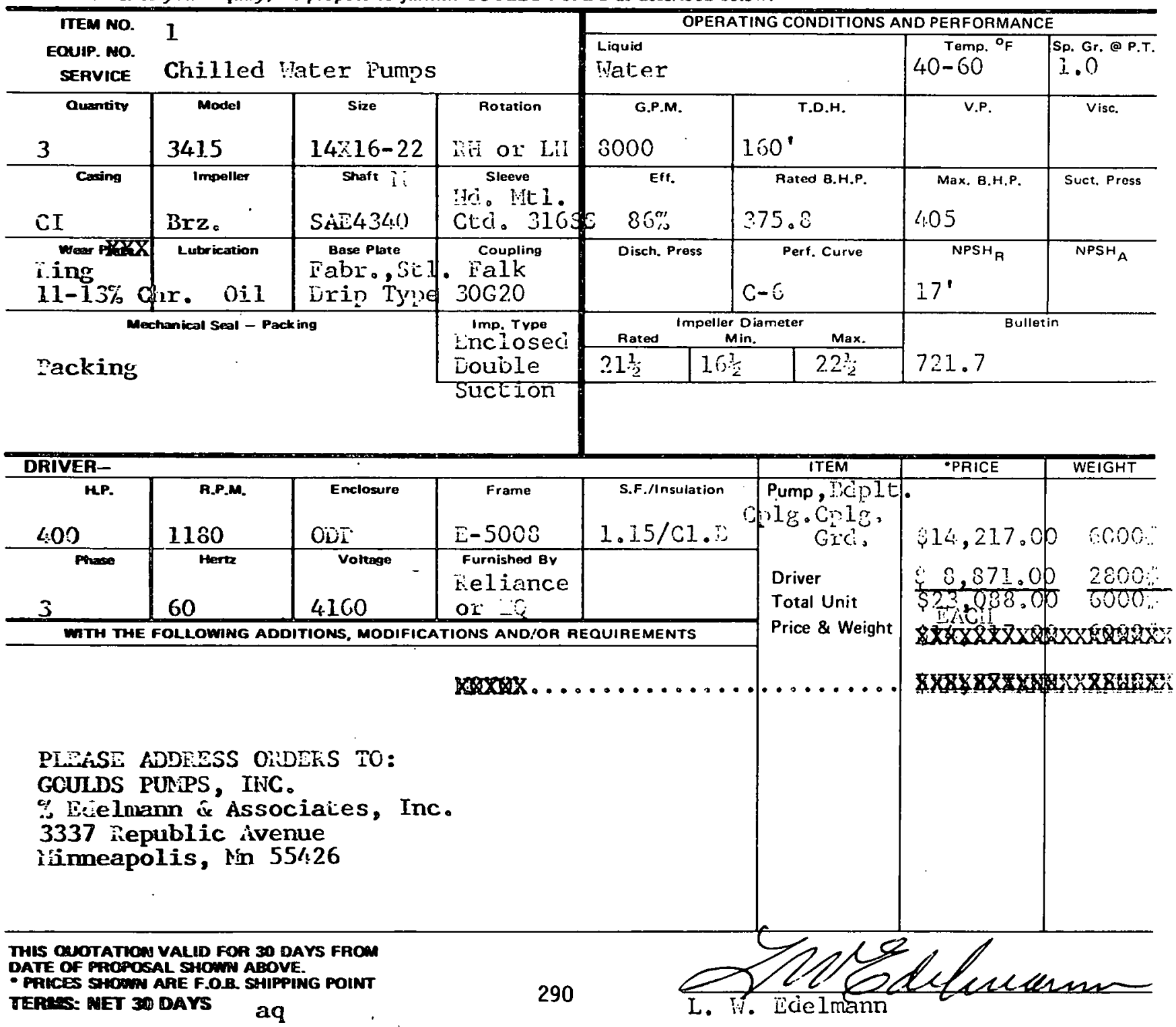


GOULDS PUMPS, INC.

SENECA FAIS NEW YOPK BI48

\section{CENTRIFUGAL PUMP \\ QUOTATION}

REPLY TO:

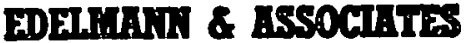 Iic.}

8987 Republic Ava

Minneapolis, MN 5548.

Phone: AC 618-987-4364 TLX 29-0874

To: $05 .:$

Attention:

Inquiry Date:

Inquiry No.:

In mower to your inquïry, we propose to fumish GOULDS PUMPS as described below:

\begin{tabular}{|c|c|c|c|c|c|c|c|}
\hline \multirow{2}{*}{$\begin{array}{l}\text { ITEM NO. } \\
\text { EQUIP. NO. } \\
\text { SERVICE }\end{array}$} & \multirow{2}{*}{\multicolumn{3}{|c|}{$\begin{array}{l}2 \\
\text { Condenser Tater rumps }\end{array}$}} & \multicolumn{4}{|c|}{ OPERATING CONDITIONS AND PERFORMANCE } \\
\hline & & & & \multicolumn{2}{|c|}{$\begin{array}{l}\text { Liquid } \\
\text { r:Tater }\end{array}$} & \multirow{3}{*}{$\begin{array}{c}\text { Tomp. }{ }^{\circ} \mathbf{F} \\
\text { V.P. }\end{array}$} & \multirow{3}{*}{ 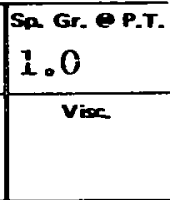 } \\
\hline Quantity & Model & Size & Rotation & G.P.M. & T.D.H. & & \\
\hline 3 & $3 \div 20$ & $24 \div 24-26^{\prime}$ & I.H or & II: 15,000 & $85^{\circ}$ & & \\
\hline $\begin{array}{ll} & \text { Cosing } \\
g r & \end{array}$ & $\begin{array}{l}\text { Impeller } \\
\text { Srž。 }\end{array}$ & Shaft & $\begin{array}{r}\text { Sleeve } \\
316 S 5\end{array}$ & $35 \%$ & $\begin{array}{l}\text { Pated B.H.P. } \\
378.8\end{array}$ & $\begin{array}{l}\text { Max. B.H.P. } \\
400\end{array}$ & Sexct Press \\
\hline $\begin{array}{l}\text { wearienth } \\
\text { irz. }\end{array}$ & $\begin{array}{l}\text { Lubrication } \\
\text { Oil }\end{array}$ & $\begin{array}{l}\text { Base Plate } \\
\text { Fabi. Stl } \\
\text { Srip Type }\end{array}$ & $\begin{array}{l}\text { Coupling } \\
\text { Fa } 1 \mathrm{k} \\
35 \mathrm{G} 20 \\
\end{array}$ & Disch. Press & $\begin{array}{l}\text { Pert. Curve } \\
\mathrm{C}-14 \\
\end{array}$ & $18^{{ }^{\text {NPSH }}}$ & $\mathrm{NPSH}_{A}$ \\
\hline acking & hanical Seal - P & & $\begin{array}{l}\text { Imp Type } \\
\text { Enclosed } \\
\text { Double }\end{array}$ & 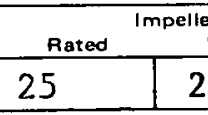 & \begin{tabular}{|l|l|}
\multicolumn{2}{|l|}{ Diameter } \\
\begin{tabular}{l|l} 
fin. \\
(inax
\end{tabular} \\
\end{tabular} & 721.10 & \\
\hline
\end{tabular}

\begin{tabular}{|c|c|c|c|c|}
\hline \multicolumn{5}{|c|}{ DRIVER- } \\
\hline H.P. & R.P.M. & Enclosure & Frame & S.F./Insulation \\
\hline 400 & 710 & OUP & E5310 & $1.15 / \mathrm{Cl} . \mathrm{D}$. \\
\hline Phase & Hert & Voltage & Furnished $B V$ & \\
\hline 3 & 60 & 4160 & & \\
\hline
\end{tabular}

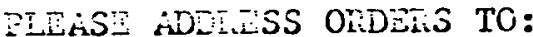

GOULSS PU:PS, INC.

:i ielmann í Associates, Inc。

3337 Iepublic Avenue

inneapolis, in 55426

THIS QUOTATION VALID FOR 30 DAYS FROM

DATE OF PROPOSAL SHOWN ABOVE.

- PRICES SHOWN ARE F.O.B. SHIPPING POINT

TERMS: NET 30 DAYS

aq

Date: $2 / 13 / 70$

Proposal No.: 7823928

Revision No.: PRELIYIINAIIY ESTITATE

Copies:

Afl quotations sublect to terms and conditions on the reverze side except

as notied on Pese______ ettuched

SMIPAENAT: Ow best estimate at this time is $36-40$ moes after cornplete eneinearing and mmufacturing information and full approval to proceed with work.

Page: 2 of 4 
(T) GOULDS PUMPS, INC.

SENECA FAULS NEW YOAK 13148

CENTRIFUGAL PUMP

QUOTATION

\section{REPLY TO:

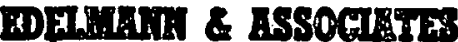 \\ Lit. \\ 8887 Republit Ava \\ Minneapolis MN 6549 \\ Phone: AC 612-827-4864 \\ TLX 28-0874}

To:

OSM

Attention:

Date:

Proposal No.:

Rèvision No.

All quofations wubject to terms and conditions on the rever se slde oxcept

a noted on Page attached.

BHIPMEait : iOur best estimate ot this time b. $40-44$ wooks after complete engineering and manufacturing Information and full approval to proceed with work.

Inquiry Date:

Inquiry No.:

In answer to your inquiry, we propose to fumish GOULDS PUMPS as described below:

\begin{tabular}{|c|c|c|c|c|c|c|c|}
\hline \multirow{2}{*}{$\begin{array}{l}\text { ITEM NO. } \\
\text { EQUIP. NO. } \\
\text { SERVICE }\end{array}$} & & \multicolumn{4}{|c|}{ OPERATING CONDITIONS AND PERFORMANCE } \\
\hline & Notor D & en Boil & Feed Pump & \multicolumn{2}{|c|}{ Water } & \multirow{2}{*}{$\begin{array}{c}\text { Tamp. }^{\circ} \mathrm{F} \\
320^{\circ} \\
\text { V.P. }\end{array}$} & \multirow{2}{*}{\begin{tabular}{|l}
.9 \\
Sp. Gr. @P.T. \\
Visc.
\end{tabular}} \\
\hline Quantity & $\begin{array}{l}\text { Model } \\
3300\end{array}$ & $\begin{array}{l}\text { Size } \\
3 \times 4-9 \\
9 \text { stg. }\end{array}$ & $\begin{array}{l}\text { Rotation } \\
\text { MH or LH }\end{array}$ & $\begin{array}{l}\text { G.P.M. } \\
210^{-}\end{array}$ & \begin{tabular}{|l} 
T.D.H. \\
$3200^{\prime}$
\end{tabular} & & \\
\hline $\begin{array}{l}\quad \text { Casing } \\
\text { Carbon } \\
\text { Steel }\end{array}$ & 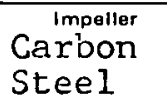 & $\begin{array}{l}\text { Shaft } \\
12-14 \% \\
\text { Chrome }\end{array}$ & $\begin{array}{l}\text { Sleeve } \\
\text { AlS1 } \\
420 \text { Chr. }\end{array}$ & $\begin{array}{cc} & \text { Eff. } \\
\text { FH } & 48 \%\end{array}$ & $\begin{array}{l}\text { Rated B.H.P. } \\
318\end{array}$ & $\begin{array}{l}\text { Max. B.H.P. } \\
350\end{array}$ & Suct. Press \\
\hline $\begin{array}{c}\text { wearexx } \\
\text { Lings } \\
11-13 \%\end{array}$ & $\begin{array}{l}\text { Lubrication } \\
\text { Lr. Oil }\end{array}$ & $\begin{array}{l}\text { Base Plate } \\
\text { Fab. } \\
\text { St } 1 \text {. }\end{array}$ & \begin{tabular}{l}
\multicolumn{1}{c}{ Coupling } \\
Falk \\
$1035 \mathrm{G} 10$
\end{tabular} & $\begin{array}{c}\text { Disch. Press } \\
1333 \text { PSIG }\end{array}$ & $\begin{array}{l}\text { Perf. Curve } \\
\mathrm{C}-1\end{array}$ & $12^{{ }^{\mathrm{NPSH}_{\mathrm{R}}}}$ & $\mathrm{NPSH}_{A}$ \\
\hline Packing & hanical Seal $-p$ & & $\begin{array}{l}\text { Imp. Type } \\
\text { Enclosed }\end{array}$ & Rated Impeller & $\begin{array}{l}\text { Diameter } \\
\text { Aln. } \\
\end{array}$ & 722.1 & \\
\hline
\end{tabular}

\begin{tabular}{|c|c|c|c|c|}
\hline DRIVER- & & & & \\
\hline H.P. & R.P.M. & Enclosure & Frame & S.F./Insulation \\
\hline 350 & 3500 & ODP & E5006 & $1.15 / \mathrm{Cl} . \mathrm{B}$ \\
\hline Phase & $60^{\text {Hertz }}$ & $\begin{array}{l}\text { Voltage } \\
4160\end{array}$ & $\begin{array}{l}\text { Furnished Bv } \\
\text { Reliance } \\
\text { or EQ }\end{array}$ & \\
\hline
\end{tabular}

PLEASE ADDRESS ORDERS TO:

GOULDS PUIPS, INC.

$\%$ Edelmann \& Associates, Inc.

3337 Republic Avenue

Minneapolis, Mn 55426

\begin{tabular}{|c|c|c|}
\hline ITEM & PRICE & WEIGHT \\
\hline $\begin{array}{l}\text { Pump, Bdplt } \\
\text { Cplg. Cplg } \\
\text { Grd. }\end{array}$ & $\$ 35$ & $6000 z^{\prime \prime}$ \\
\hline $\begin{array}{l}\text { Driver } \\
\text { Total Unit }\end{array}$ & $\$ 9,320.0 p$ & 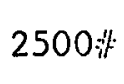 \\
\hline Price \& Weight & $\$ 44$ & 8500 \\
\hline
\end{tabular}

THIS QUOTATION VALID FOR 30 DAYS FROM

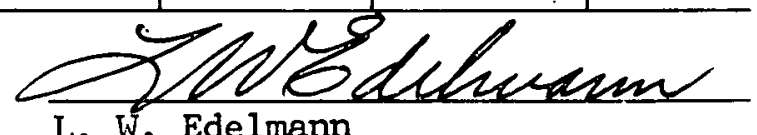


(6) GOULDS PUMPS. INC. SENECA FALLS NEW YORK B148

\section{CENTRIFUGAL PUMP \\ QUOTATION}

\section{REPLY TO: \\ BDELMART \& ASSOCIRTES Titc. \\ 8887 Rojublic Ava. Minneapolis, MN 65426 \\ Phone: AC 612-927-4864 TLX 29-0874}

To: OSM

All quotations arbject to terms and

conditions on the reveres side except

as noted on Page attached.

SH+1PMENT: Our best estimate at this time is $40-44$ weeks after com plete engineering and menufacturing Information and full approval to proceed with work.

Date: 2/13/78 Page: 4 of 4 Proposal No.: $78 \mathrm{M} 2392 \mathrm{E}$ Revision No.: PRELIMINARY. EST IMATE

Copies:

Attention: Inquiry Date:

Inquiry No.:

In answer to your inquiry, we propose to furnish GOULDS PUMPS as described below:

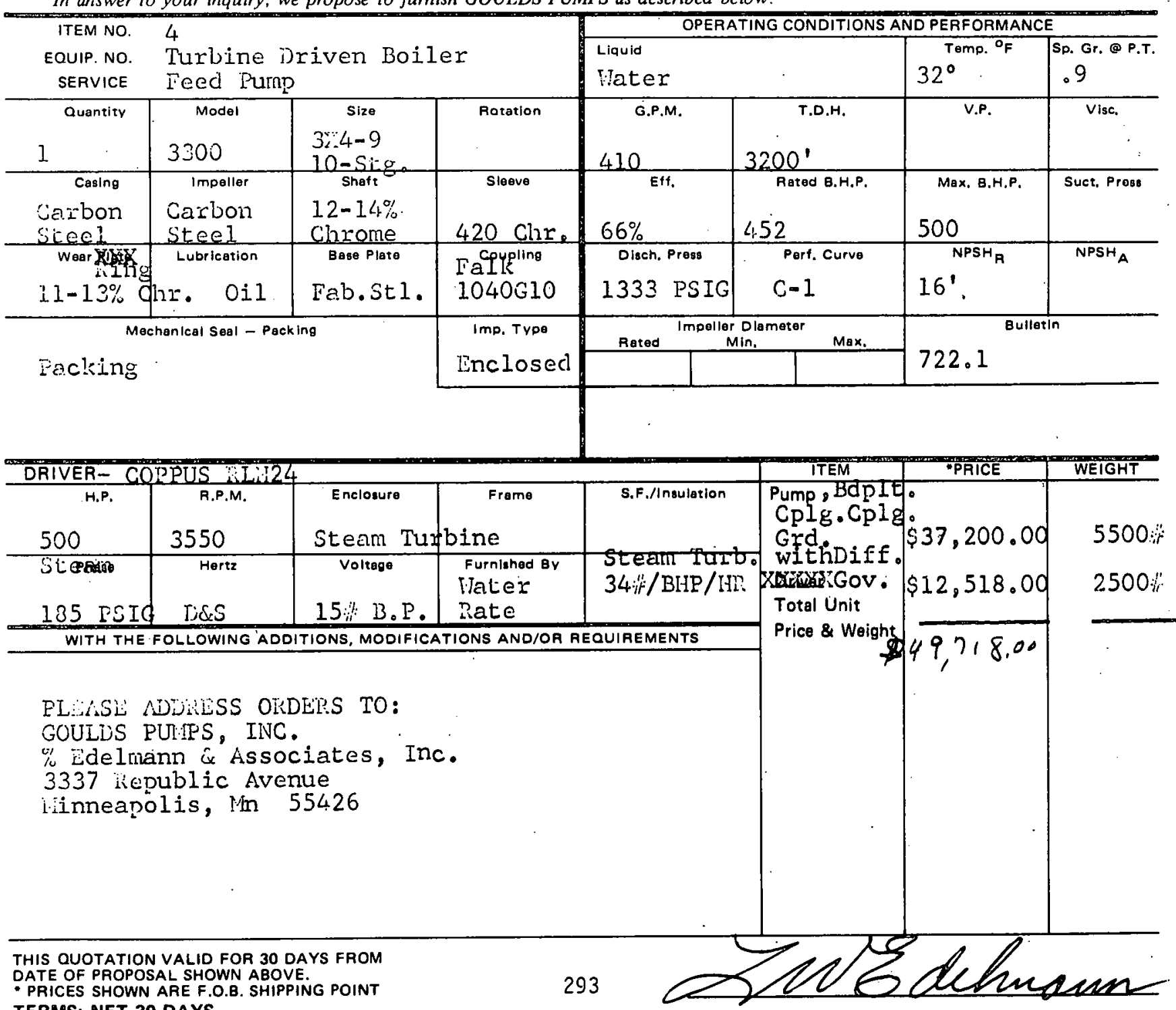

TERMS: NET 30 DAYS
L. W. Edelmann 


\section{(1) THE MECHANICAL SERVICE COMPANY 1500 EAST 79TH STREET • MINNEAPOLIS, MINNESOTA 55420 \\ PHONE (612) 854-4569}

February 16, 1978

Mr. Larry Whalen

Orr-Schelen-Mayeron \& Associates, Inc.

Suite 238 Hennepin Square

2021 East Hennepin Avenue

Minneapolis, Minnesota 55413

Subject: Clarage Fan

Dear Larry:

As per our phone conversation, we have selected a wet fan, designed for 110,400 ACFM @30" static pressure, test block, with a saturated temperature of $145^{\circ} \mathrm{F}$, operating @881 RPM, using $712 \mathrm{BHP}$ @ conditions. The fan would be a CLARAGE size 178, series 1240 , Type XLR, $100 \%$ double width, double inlet, with $2 \mathrm{~L}$ whee1, arranement $3 \mathrm{D} 2$. Fan is to have spin control inlet dampers, 1/4" scroll liners, side liners, 3 drains, 3 access doors, split housing, inlet boxes $3 / 8^{\prime \prime}$ thick, sides $3 / 8^{\prime \prime}$ thick, scrol1 $3 / 8^{\prime \prime}$ thick, wheels to have blade liners of $1 / 4^{\prime \prime}$, blades being $3 / 8^{\prime \prime}$ thick, rim $3 / 8^{\prime \prime}$ thick, fan wheel shaft, etc., to be manufactured out of $316 \mathrm{ELC}$ stainless stee1. W. $R_{2}$ of the $f a n$ is 24,671 , and the unit to use dodge sleeve oil water cooled bearings, with the bearing diameter of $4.4375^{\prime \prime}$.

Budget price for fan based on today's pricing $\$ 140,000.00$

If you have any questions, please do not hesitate to contact me at your convenience.

This fan is designed for dual drive.

Very truly yours,

THE MECHANICAL SERV ICE COMPANY
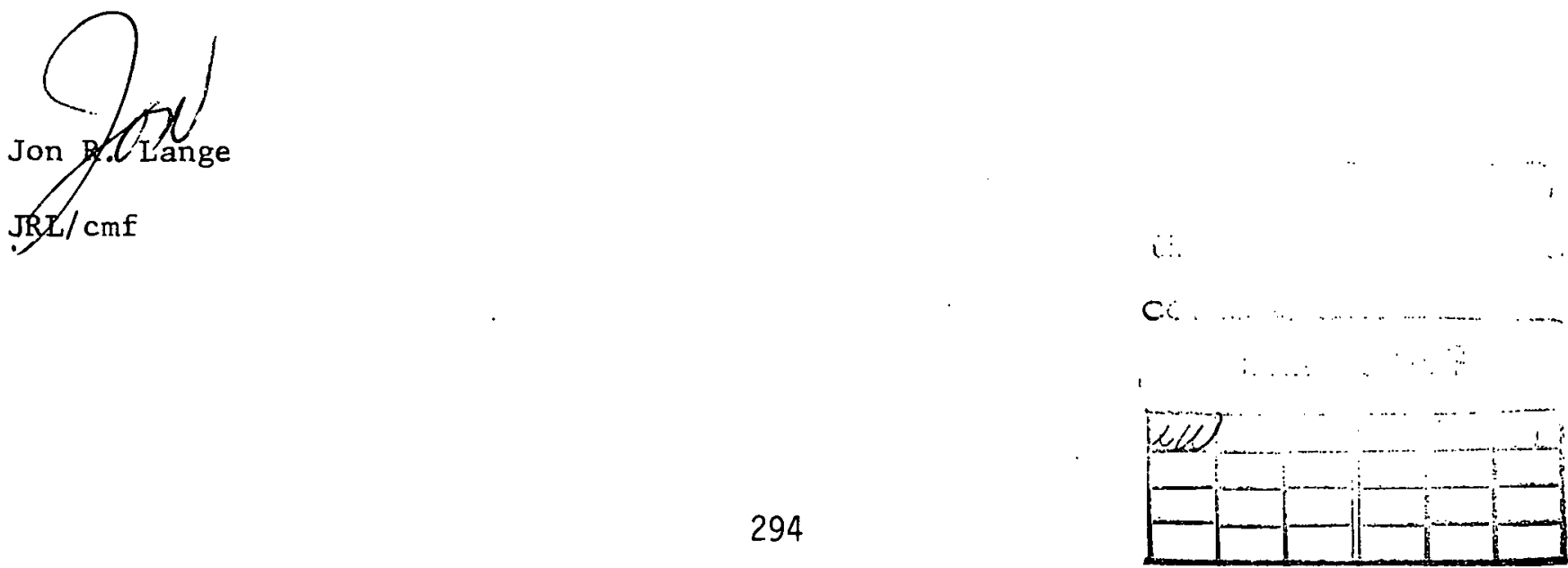


\section{Urited Conveyor Corporation}

300 wilmot Road • Deertield, Illinols 60015 • Phone: (312) 948-0400 • Cable: UNICONVEY. Deerfield, Illinois • Telex: 25-4467

March 1, 1978

$$
\begin{gathered}
\text { Draxton Sales, Inc. } \\
\text { P.O. Box } 12868 \\
\text { St. Paul, Minnesota } 55112 \\
\text { (612) 483-3553 }
\end{gathered}
$$

Mr. Larry Whalen

Orr, Schelen, Mayeron \& Associates

Suite 238, Fennepin Square

2021 East Hennepin Avenue

Minneapolis, Minnesota 55413

RE: Health Education Authority of Louisiana

Grid Connected, Integrated Comrunity Energy System

New Orleans, Louisiana

United Conveyor Ash Handing System

Budget Price

Dear Larry:

We have reviewed the basic layout drawings for this project. From this material, we have determined that it should cost approximately $\$ 135,000.00$ to provide the equipment for boiler system ash removal. We would suggest a budget figure of approximately $\$ 220,000.00$ for material and erection. The number does not include the ash storage silo, but does. include the silo accessories.

If you have any questions, please call at your convenience.

Yours truly,

DRAXTON SALES, INC.

District Representative for

UNITED CONVEYOR CORPORATION

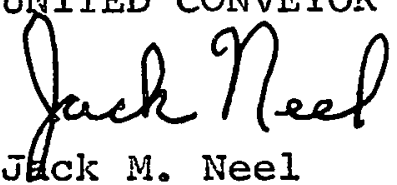

JPIJ : sk

cc: G. H. Reed

Baton Rouge

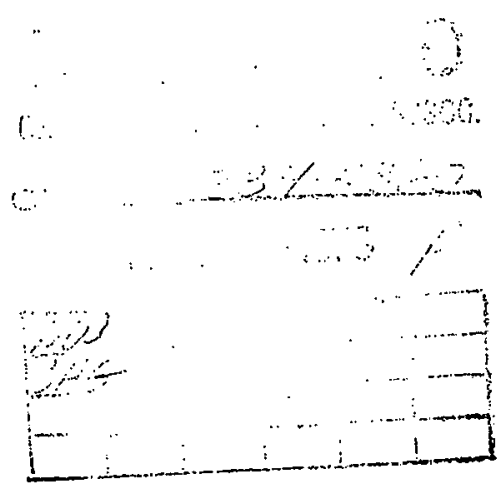




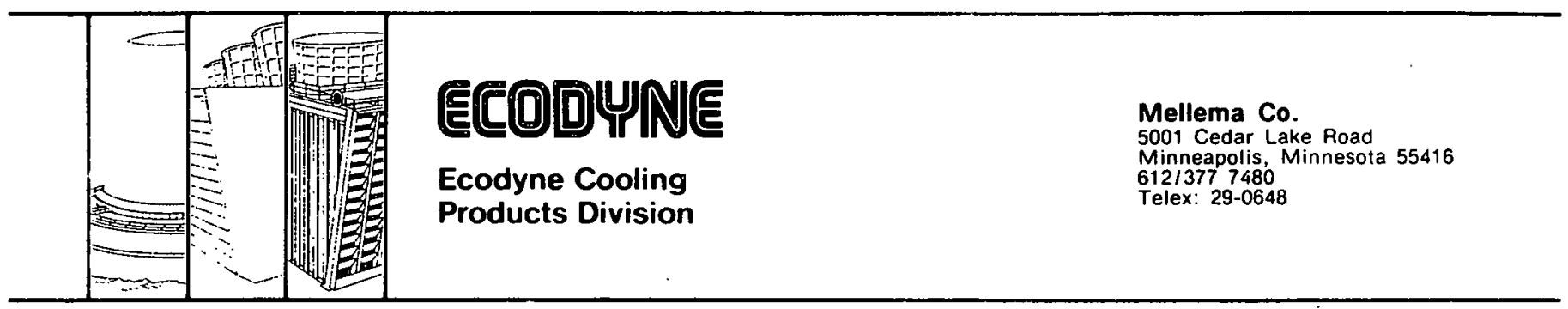

February 22, 1978

Orr-Schelen-Mayeron \& Associates

2021 Hennepin Avenue, East

Minneapol is, Minnesota 55413

Attention: Mr. Larry Whalen

Subject: Ecodyne Cooling Tower for Health \& Education Authority

of Louisiana

File Reference MP-A-7276

\section{Gentlemen:}

The above-referenced project involves the use an Ecodyne Counterflow Cooling Tower Type 460-61112. Mr. Whalen indicated that a budget estimate is now required as the next step for this project. is:

We are pleased to advise that the estimate price for this tower on this project

$$
\$ 700,000.00
$$

As indicated, this is an estimated price and is subject to changes as final specifications become more defined.

Should you have any questions or comments concerning this project, please do not hesitate to contact either the writer or Mr. George Carney at our Minneapolis office.

$J A B: b j m$

cc: Ecodyne
Very truly yours, ECODYNE COOLING PRODUCTS Represented by: Mell ema Co.
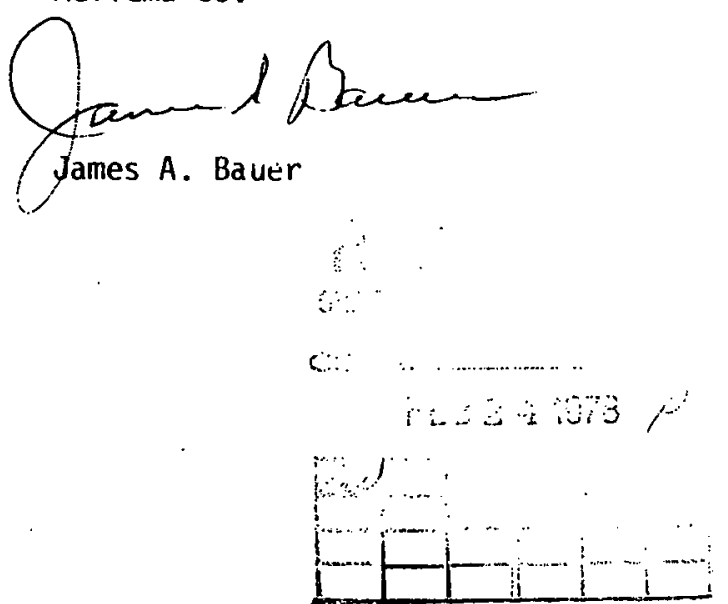


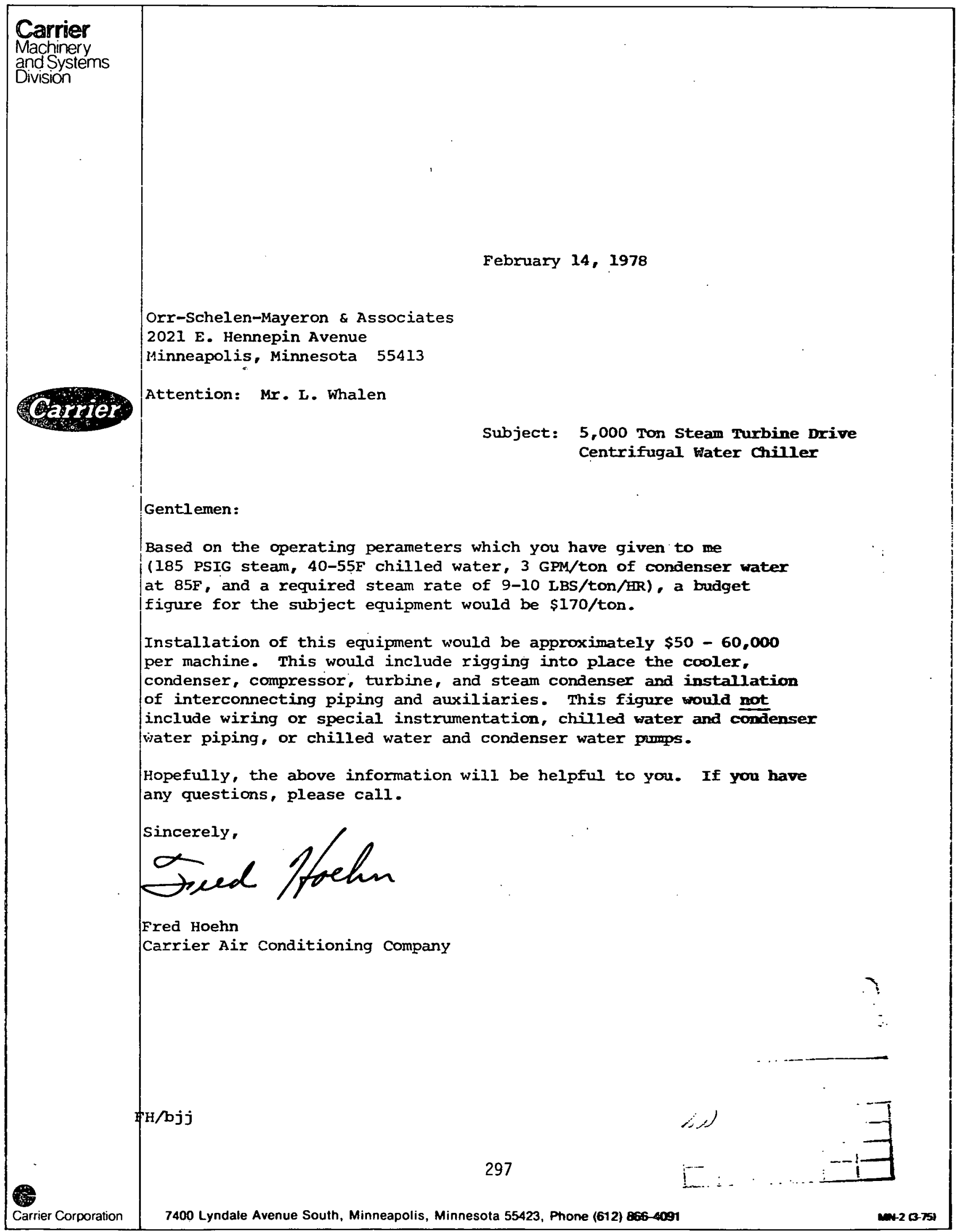


ERIE, PA U.S.A. 16503 - TELEPHONE (814) 452.6421

REPLY TO: POWER PROCESS EQUIPMENT COMPANY, District Sales Agent

6032 West 37 th Street Minneapolis, MN 55416 • Phone: (612) 920-5525

7 February 1978

Orr Schelen Mayeron \& Assoc.

2021 East Hennepin Avenue

Suite 238

Minneapolis, Minnesota 55413

Attention: Mr. Larry Whelan

Subject: GRID Ices

Heal

New Orleans

Gentlemen:

If you placed an order today for two (2) 200,000 lb. per hour 1250 PSIG $/ 950^{\circ} \mathrm{F}$ complete with forced draft fan Erie City Trava-Grate, dust collector, economizer, combustion control, all erected and cut into service would cost approximately $\$ 3,200.000$ each, or $\$ 6,400.000$ for the two boilers.

This does not include the back end, including scrubber or induced draft fan.

The estimated shipping date would be 9 months to one year, and the erection time approximately 9 months.

Sincerely,

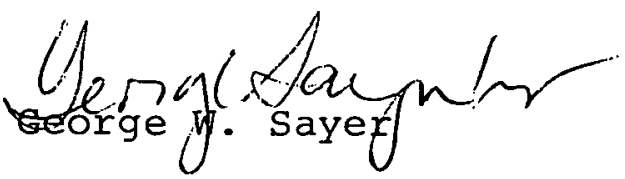

GWS : rkp 


\section{APPENDIX $\quad C-1$}

HEAL INSTITUTIONS' LETTERS OF INTEREST 


\section{New Orineans Public Service Inc.}

POST OFPICE BOX 60340

NEW ORLEANS, LOOISIANA 70160

Mr. M. C. Abrahm

Project Manager

HEAL Grid-ICES Project

Health Education Authority of Louisiana

325 Loyola Avenue - Room 213

New Orleans, LA 70112

Dear Mr. Abrahm:

This will confirm that the Rate Schedules as shown on pp. 60-66 of the Draft Final Report Phase II (Stage 2) for the Grid Connected Integrated Community Energy System will require no change at this time. However, we do call your attention to the note at the bottom of pp. 63 and 66 , i.e., "These rates are subject to change pending future revisions in rate design data." Thus, any factor(s) which affect plant owning and operating costs could force a revision to these rate schedules.

\section{Very truly yours,

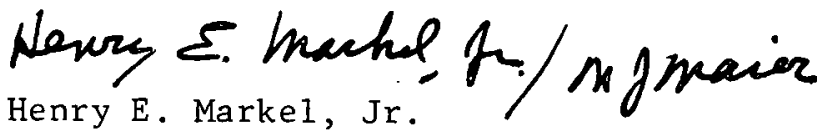

$\mathrm{HEM} / \mathrm{st} j$

cc: Messrs. M. L. Hurstell

V. D. Seifert

J. E. Morrison

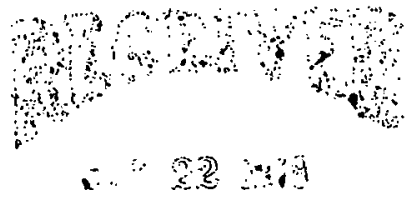




\section{LOUISIANA STATE UNIVERSITY MEDICAL CENTER \\ 1440 CANAL STREET • SUITE 1510 \\ NEW ORLEANS, LA. 70112}

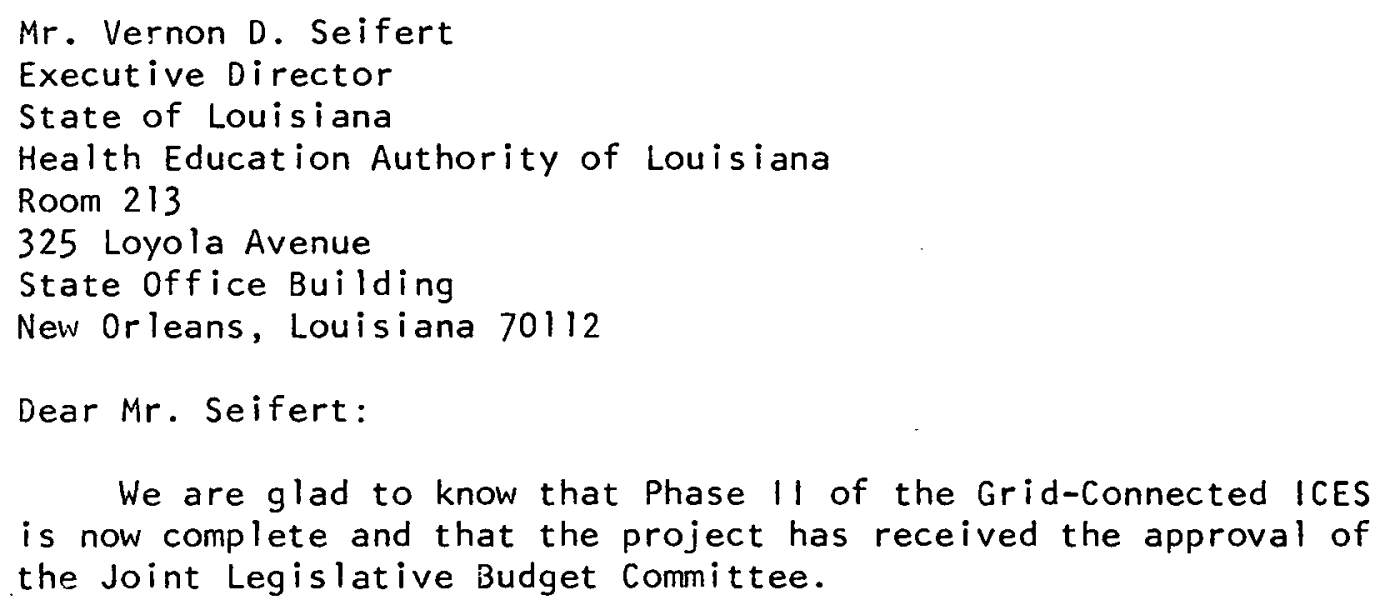

We are glad to know that Phase 11 of the Grid-Connected ICES is now complete and that the project has received the approval of the Joint Legislative Budget Committee.

Our interest in the project continues and it will have our full cooperation and support with the hope that it will prove to be an efficient and economical answer to our energy requirements.

of course, final decisions and commitments with respect to the use of any facility that might result from this project would depend on proven documented economic advantages to this institution and achieved environmental standards.

Best wishes for continued progress on the project and please call on us when our further participation is indicated.

Sincerely,

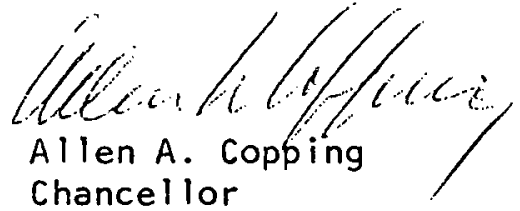

$\mathrm{AAC} / \mathrm{dmm}$

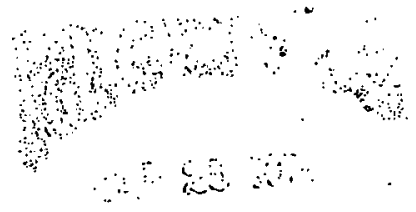


EVE, EAR, NOSE

\& THROAT HOSPITAL

Affilialed with the

Ochsner Medical Institutions

145 Elk Place

New Orleans, Louisiana 70112

Phone: 504/581-3300

September 20, 1978

Mr. C. C. Clifton, Jr.

Chairman

Health Education Authority of Louisiana

Room 213, 325 Loyola Avenue

State Office Building

New Orleans, Louisiana 70112

Dear Mr. Clifton:

The Eye \& Ear Institute has been well informed concerning the progress made towards the development of a Grid Connected Integrated Community Energy System. We appreciate the opportunity to review the draft FINAL REPORT on Phase II of this project.

Although there are many unanswered questions concerning future federal energy policies, the Eye \& Ear Institute remains quite interested in the plans for a centralized energy facility to serve us as a member of the Louisiana Medical Complex. With the uncertainty of natural gas prices, the plan to create a facility with multi-fuel burning capacity may prove to be of considerable value to us. The underlying theme of such a centralized, multi-fuel burning energy facility would be on cost containment.

The Eye \& Ear Institute pledges our continued support for this development and we are pleased to cooperate with you. This is with the understanding that final decisions regarding the development of the facility will only follow reasonable stability in fuel prices and a demonstrated economic advantage to our institution.

$\mathrm{CDM}: \mathrm{ju}$

cc: C. M. Dougherty, Jr.

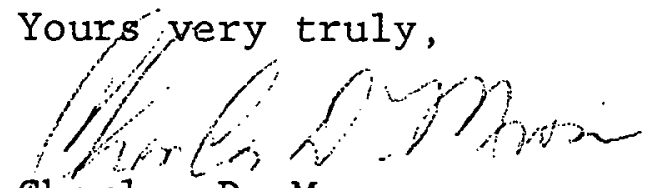

Charles D. Mross

Executive Vice President

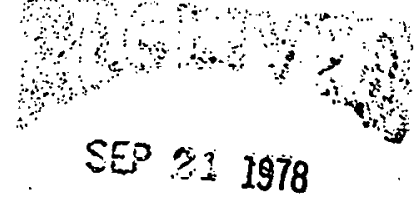




\section{TULANE UNIVERSITY}

NEW ORLEANS, LA. 70112

Chancellor of

Tulane Medical Center

1430 Tulane Avenue

September 25, 1978

Mr. Vernon D. Seifert

Executive Director

Health Education Authority of

Louisiana

Room 213

325 Loyola Avenue - State office

Building

New Orleans, Louisiana 70112

Dear Mr. Seifert:

Thank you for the opportunity to review the draft Final Report on Phase 11 of the Grid-Connected ICES project.

While we are aware of the unsettled position, currently, of Federal Energy Policy and the proposed changes in Environmental Standards, we continue to be very interested in the development of the proposed central thermal energy facility with which to serve our institutions within the Louisiana Medical Complex. The plan to create a facility with multifuel burning capacity may prove to be of considerable value to us, dependent upon the direction Federal policy may take, particularly as it impacts on natural gas price levels.

The draft final report suggests that future energy costs may be modified significantly through the creation of this central facility. The possible achievement of substantial savings is, of course. of considerable interest to us.

We have been pleased to cooperate with you in the development of this study and would like to pledge our continued support for this development, with the understanding that final decisions regarding future development of the facility wili only follow reasonable stability in fuel price levels, dependable environmental standards that are achievable and well demonstrated economic advantage to our institution.

cC: S. L. Drumm

C. C. Clifton, Jr. John Morrison Henry Markel

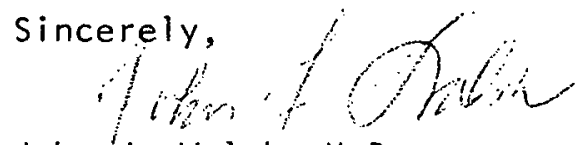

John J. Walsh, M.D. Chapcellor

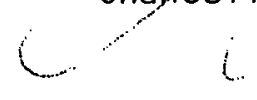

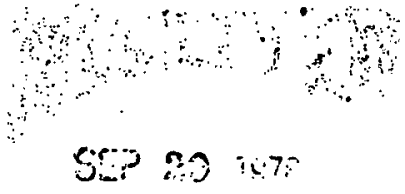



OFFICE OF CHARITY HOSPITAL AT NEW ORLEANS

Office of the Assistant Secretary

1532 Tulane Avenue

New Orleans, Louisiana 70140

October 2, 1978

Mr. Vernon D. Seifert

Executive Director

State of Louisiana

Healch Education Authority

325 Loyola Avenue, Room 213

State Office. Building

New Orleans, Louisiana 70112

Dear Mr. Seifert:

Thank you for the opportunity to review the draft Final Report on Phase II of the Grid-Connected ICES project.

While we are aware of the unsettled position, currently, of Federal Energy Policy and the proposed changes in Environmental Standards, we continue to be very interested in the development of the proposed central thermal energy facility with which to serve our Institutions within the Louisiana Medical Complex. The plan to create a facility with multifuel burning capacity may prove to be of considerable value to us, dependent upon the direction Federal policy may take, particularly, as it impacts on natural gas price levels.

The draft final report suggests that future energy costs may be modified significantly through the creation of this central facility. The possible achievement of substantial savings is, of course, of considerable interest to us.

We have been pleased to cooperate with you in the development of this study and would like to pledge our continued support for this development, with the understanding that final decisions regarding future development of the facility will only follow reasonable stability in fuel price levels, dependable environmental standards that are achievable and well demonstrated economic advantage to our Instituion.
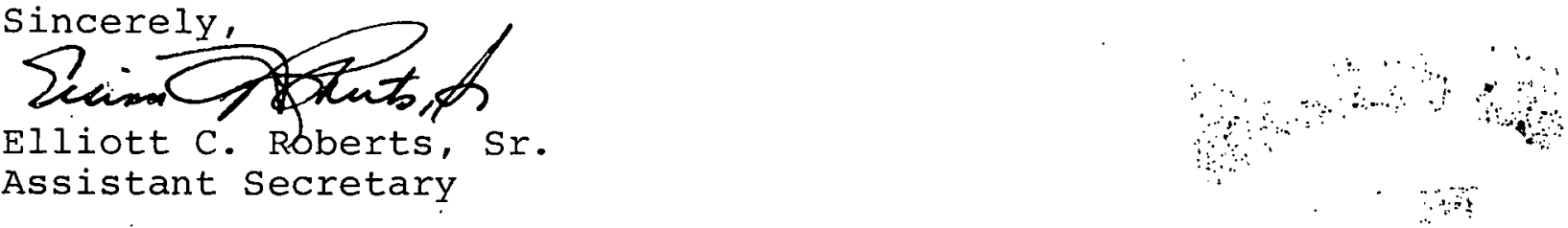

Assistant Secretary

fC: HEAL

$\mathrm{ECR}, \mathrm{Sr} / \mathrm{bb}$ 